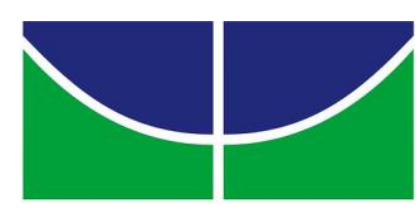

UNIVERSIDADE DE BRASÍLIA

FACULDADE DE COMUNICAÇÃO

PROGRAMA DE PÓS-GRADUAÇÃO

A CONSTRUÇÃO DO PERSONAGEM JOSÉ DIRCEU PELA REVISTA VEJA

DURANTE E APÓS O ESCÂNDALO DO MENSALÃO

ALETHEIA PATRICE RODRIGUES VIEIRA

- DEZEMBRO DE 2015 - 


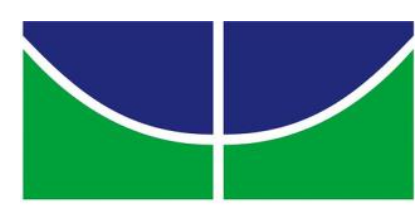

UNIVERSIDADE DE BRASÍLIA

FACULDADE DE COMUNICAÇÃO

PROGRAMA DE PÓS-GRADUAÇÃO

\section{A CONSTRUÇÃO DO PERSONAGEM JOSÉ DIRCEU PELA REVISTA VEJA DURANTE E APÓS O ESCÂNDALO DO MENSALÃO}

\section{ALETHEIA PATRICE RODRIGUES VIEIRA}

Dissertação apresentada ao Programa de PósGraduação em Comunicação da Universidade de Brasília (UnB) como parte dos requisitos para obtenção do grau de mestre.

Linha de pesquisa: Jornalismo e Sociedade.

Orientadora: Profa. Dra. Liziane Soares Guazina.

- DEZEMBRO DE 2015 - 
Para minha mãe e meu pai. 


\section{AGRADECIMENTOS}

À professora Drª Liziane Soares Guazina, minha orientadora, pela aposta no meu projeto desde quando ainda eram coisas da minha cabeça, pelo apoio e dedicação nos momentos bons e difíceis;

Aos professores Célia Ladeira Mota e Luiz Gonzaga Motta pelo incentivo à minha entrada no Mestrado e a todos os professores do Programa de Pós-Graduação em Comunicação da Universidade de Brasília;

Família, amigos e colegas de trabalho. Força e amparo nas horas difíceis, nas grandes e pequenas decisões.

Obrigada: Jéssyca Pinho, Joyce Pinho e Ramón Diego - meus primos irmãos sempre comigo; Jamile Guerra, irmã postiça e grande incentivadora; Evanise Santos, a fada madrinha deste trabalho.

Adison Ferreira, Diego Andrade, Fernanda Ferreira, Guto Lobato, Igor Dias, Ingrid Pereira, Pedro Loureiro de Bragança e Wanderson Marçal. A distância não faz diferença.

Aos meninos da ESPN Brasil pela ajuda nas horas de desânimo e solidão que a vida acadêmica nos impõe. Aos amigos Paulo Andrade, o locutor que ajudou a me concentrar tantas vezes e William Tavares pelos programas matinais e algumas risadas.

A todos os colegas da UnB, especialmente Bruno Araújo, Glauciene Lara e Leylliane Alves, também amigos e apoiadores.

Aos meus pais Nestor e Auxiliadora, os grandes responsáveis pelas minhas conquistas. 
Ou se morre como herói, ou vive-se o bastante para se tornar o vilão.

Trecho do filme "Batman - O Cavaleiro das Trevas" (DC Comics) 


\section{RESUMO}

Nesta pesquisa, o objetivo foi identificar de que forma a revista Veja construiu o personagem José Dirceu em sua narrativa jornalística durante e após o escândalo do Mensalão. Ex-ministro-chefe da Casa Civil, Dirceu foi alvo das acusações de ter chefiado um esquema de corrupção, conhecido como Mensalão, em que o Partido dos Trabalhadores - PT teria pago parlamentares para que votassem em favor do primeiro governo do ex-presidente Luiz Inácio Lula da Silva no Congresso Nacional. De 2005, quando escândalo eclodiu, a 2014, a revista Veja dedicou dez capas a José Dirceu onde foram publicadas as doze matérias que foram analisadas durante a pesquisa. Por meio de elementos de análise pragmática e estrutural da narrativa traçamos quais funções e características personificadas a revista atribui a José Dirceu no período que engloba o auge do escândalo, o julgamento do caso e a prisão do ex-ministro. Também foram analisadas as estratégias argumentativas e possíveis intencionalidades da revista ao retratar o personagem. 


\begin{abstract}
In this study, we aim to identify how Veja magazine built the character José Dirceu in his journalistic narrative during and after Mensalão scandal. Ex-minister-chief of staff, Dirceu was the target of charges he led a corruption scheme known as Mensalão, where the Workers Party - PT would have paid parliamentarians to vote in favor of the former government of former President Luiz Inacio Lula da Silva in Congress. 2005, when scandal erupted in 2014, Veja magazine devoted ten covers to José Dirceu where the twelve subjects that were analyzed during the research were published. Through pragmatic and structural analysis of the narrative elements which we draw personified functions and features the magazine put José Dirceu in the period that includes the height of the scandal, the trial of the case and the arrest of the former minister. They also analyzed the argumentative strategies and possible magazine's intentions to portray the character.
\end{abstract}




\section{LISTA DE QUADROS}

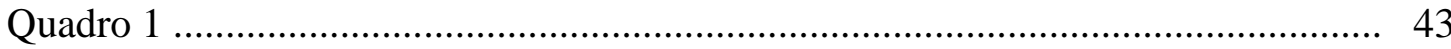

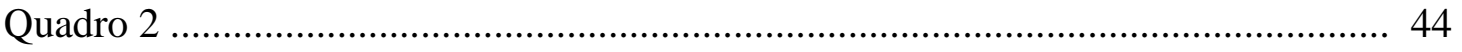

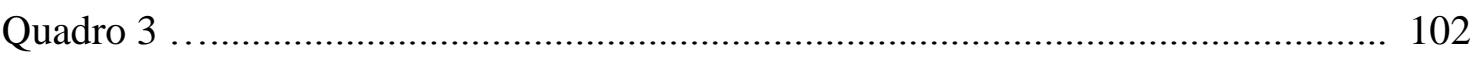

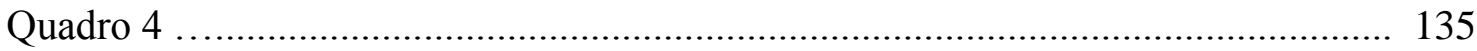

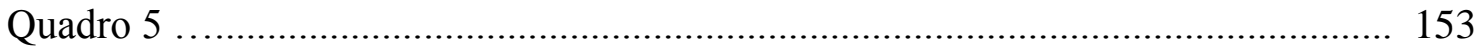

\section{LISTA DE FIGURAS}

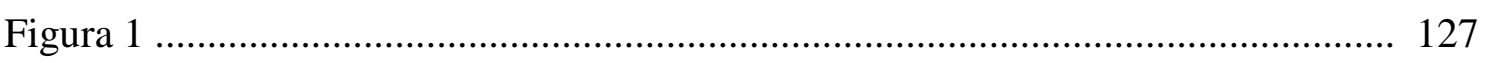

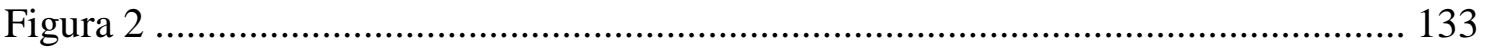

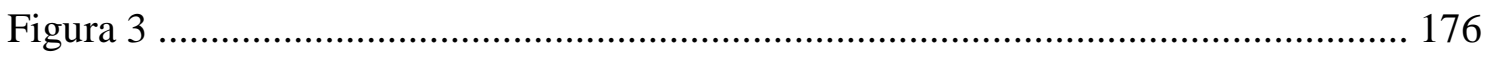

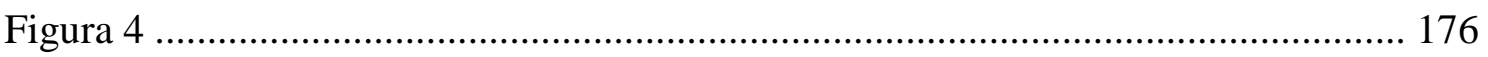

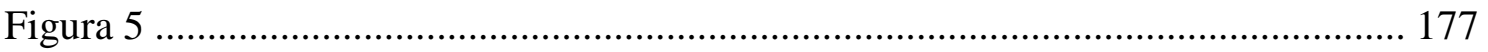

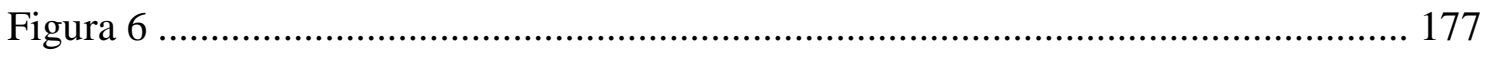

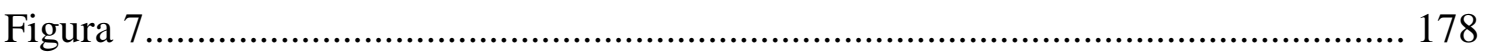

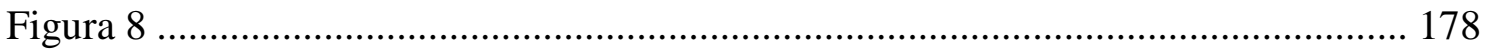

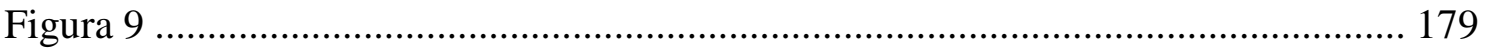

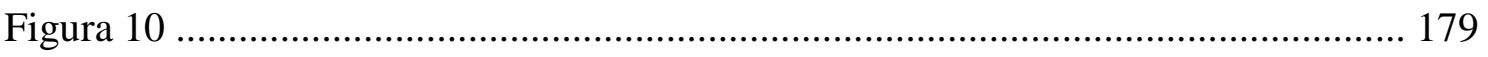

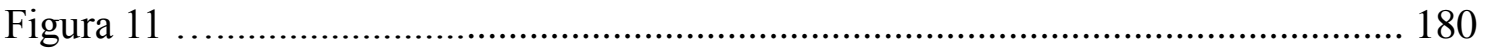




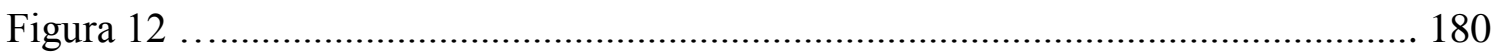




\section{SUMÁRIO}

INTRODUÇÃO

\section{CAPÍTULO I}

DESCONFIANÇA NA POLÍTICA: A INFLUÊNCIA DO JORNALISMO ... 23

1.1 - O jornalismo moderno e o mito da objetividade

1.2 - Crise na democracia e a frustração de um modelo ..................................... 28

1.3 - Brasil: mídia e declínio da confiança na política ------------------- 35

CAPÍTULO II

ESCÂNDALO POLÍTICO: CAUSAS, CONSEQUÊNCIAS, REPUTAÇÃO E

NARRATIVA …............................................................................. 45

2.1 - O escândalo político segundo Thompson ...................................................... 45

2.2 - A reputação do político envolvido em escândalos ............................................ 54

2.3 - A estrutura sequencial dos escândalos aplicada ao caso Mensalão ............. 60

CAPÍTULO III

VEJA, JOSÉ DIRCEU E O ESCÂNDALO DO MENSALÃO ..................... 63

3.1 - Histórico da Revista Veja ........................................................................... 63

3.2 - Veja x José Dirceu: o movimento de 1968 e o começo dessa história .......... 66

3.3 - "O homem que faz a cabeça do Lula"........................................................ 68

3.4 - "O Chefe da Quadrilha": a cobertura de Veja sobre o Mensalão e José

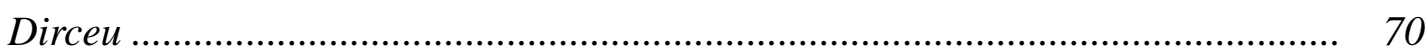

CAPÍTULO IV

PERCURSO TEÓRICO METODOLÓGICO ........................................... 81

4.1 - Aspectos Té́ricos ................................................................................ 81

4. 2 - Aspectos Metodológicos........................................................................ 101

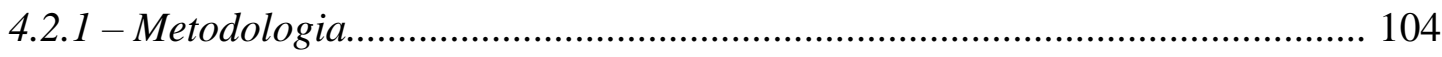

CAPÍTULO V

ANÁLISE DA NARRATIVA DA REVISTA VEJA SOBRE O PERSONAGEM JOSÉ DIRCEU DURANTE E APÓS O ESCÂNDALO DO MENSALÃO 
CONSIDERAÇÕES FINAIS

156

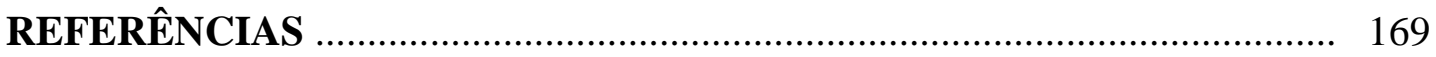

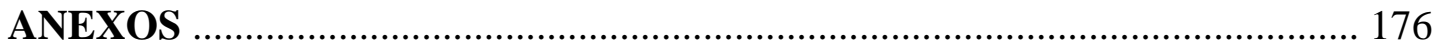




\section{INTRODUÇÃO}

Nosso interesse em estudar a personificação do ex-ministro da Casa Civil José Dirceu na mídia começou com o início do julgamento da Ação Penal - AP 470, conhecido como julgamento do Mensalão, ocorrido em 2012. Os réus eram acusados de participar de um esquema de compra de votos para aprovação de matérias legislativas de interesse do primeiro governo do ex-presidente Luís Inácio Lula da Silva no Congresso Nacional.

O escândalo eclodiu em 2005 e, com o passar dos anos, deixou de ser constante nos noticiários, deu lugar a outras histórias, outras crises nos Poderes e reaparecia sempre que surgia algum fato novo sobre os réus ou o processo judicial, por exemplo.

Junto com a retomada do assunto, a imprensa precisou fazer um resgate histórico sobre o fato para contextualizar o papel dos réus no escândalo. O julgamento trouxe à tona uma noção de consolidação do caso, do papel dos réus nos crimes para os quais foram acusados e como isso influenciou no desenvolvimento do esquema. Naquele momento, a imprensa precisaria apenas reforçar o enquadramento construído ao longo de sete anos: o Mensalão foi um esquema de corrupção, envolvendo dinheiro público e irregular, este conhecido como Caixa 2, para o financiamento de campanhas eleitorais e pagamento de parlamentares para que votassem pela aprovação da Reforma da Previdência.

As ações atribuídas a José Dirceu, ministro-chefe da Casa Civil quando o escândalo eclodiu, foram essenciais para a cobertura noticiosa sobre o caso - ele foi acusado por Roberto Jefferson de chefiar o esquema - e ainda mais depois que a denúncia do Ministério Público Federal - MPF confirmou as acusações de Jefferson e foi aceita pelo STF: Dirceu seria julgado por formação de quadrilha e corrupção ativa.

Todas as sessões foram transmitidas ao vivo pela TV Justiça e o ex-ministro voltou intensamente aos veículos de comunicação. Sobre ele, no período, foram publicadas matérias e reportagens não só a respeito da iminência de condenação, mas também sobre os possíveis planos do ex-ministro caso fosse preso, retrospectivas de sua atuação política desde a Ditadura Militar, depoimentos de amigos que o apoiavam e de pessoas que teriam testemunhado seu estilo "autoritário", "pragmático" e "mãos de ferro" quando ocupava o cargo. 
O escândalo do Mensalão é um caso recente da história brasileira e marcou a cobertura política, quando eclodiu. Seus desdobramentos, como o processo judicial e a prisão dos acusados, são noticiados pelos veículos de comunicação até o presente momento. O PT foi oposição aos governos anteriores e cobrava a ética na política. O envolvimento do partido em um caso de corrupção no comando do Poder Executivo foi considerado impactante para a opinião pública.

Destaca-se também o direcionamento da cobertura da grande imprensa em relação governo nas eleições de 2006, quando Lula foi reconduzido ao cargo. Segundo Azevedo (2011) o Mensalão continuou sendo explorado pela mídia mesmo após o indiciamento dos acusados "de forma intermitente nas páginas de opinião da grande imprensa escrita, em geral, com matérias críticas em relação ao comportamento ético do PT e do governo federal" (p.94).

Diante desse cenário, decidimos aprofundar os estudos sobre a importância de José Dirceu na cobertura jornalística da revista Veja, o que nos permite afirmar que a definição de personagem é o elemento central analisado nas narrativas da publicação. Nas observações iniciais, percebemos que o tom biográfico prevalecia nas matérias de Veja sobre Dirceu principalmente quando se tratava do Mensalão. Em alguns textos, foi possível identificar que os pontos de partida das notícias eram, muitas vezes, ações atribuídas ao exministro, entre elas, a obsessão pelo poder, que seria um dos motivos para a execução do esquema. Isso nos permitiu compreender que a definição de personagem deveria ser o elemento central analisado nas narrativas da publicação.

A revista Veja teve papel crucial na cobertura do escândalo do Mensalão. Foi o primeiro veículo a divulgar denúncias de pagamento de propina na Empresa Correios e Telégrafos, envolvendo o Partido Trabalhista Brasileiro - PTB, da base aliada do governo Lula, na edição 1905/2005, que será detalhado no capítulo sobre a contextualização do objeto de pesquisa. A notícia foi o ponto de partida para o desenvolvimento da cobertura sobre escândalo e das acusações contra José Dirceu de ser o mentor do esquema. Dessa forma, podemos dizer que a publicação iniciou a construção narrativa midiática sobre o Mensalão motivado também pelo posicionamento ideológico da revista que faz oposição ao governo do PT. 
Durante levantamento quantitativo da pesquisa, contabilizamos 31 capas de Veja sobre o governo do PT de 2003 a 2005. Treze delas dedicam-se especificamente sobre o Mensalão. Nesse período, cinco capas foram dedicadas a Dirceu, sendo três sobre o escândalo. De 1968 a 2014, Dirceu apareceu em 15 capas da revista. Dez serão analisadas na pesquisa, uma vez que o ex-ministro é personagem central em relação ao Mensalão e seus desdobramentos.

Antes mesmo do Mensalão e do próprio governo Lula, Veja dava destaque às ações atribuídas a Dirceu e o apresenta como um político frio, pragmático, que faz tudo pelo poder desde a campanha do PT à Presidência da República em 2002, a exemplo da edição 1770/2002 em matéria sobre o ex-ministro com o título "O homem que faz a cabeça de Lula". A sequência de dez capas ao longo de nove anos (2005-2014), que serão estudadas, dedicadas a Dirceu, e o livro "José Dirceu - a Biografia" escrita pelo ex-editor da revista Otávio Cabral (2013), são evidências concretas da relevância do personagem na agenda política da revista.

Como articulador da nova política de alianças do PT e por aglutinar a maioria do partido, diz Markun (2004), José Dirceu foi decisivo na eleição de Lula para a Presidência da República em 2002, após três derrotas (1989, 1994 e 1998) o que motivou a escolha para o cargo de ministro-chefe da Casa Civil em 2003, posição que o levou a ser personagem central na cobertura do escândalo do Mensalão como será tratado nos capítulos posteriores.

A partir destas constatações iniciais, partimos da seguinte pergunta-problema: como se estabeleceu a construção do personagem José Dirceu pela revista Veja durante e após o escândalo do Mensalão?

Para respondê-la, o objetivo principal foi identificar quais são as funções do personagem José Dirceu na narrativa jornalística da revista Veja durante e após o escândalo do Mensalão. No total, foram analisadas 12 matérias em dez edições em que Dirceu desempenhou papel central na cobertura e foi objeto de capa da revista entre os anos de 2005 e 2014, período que engloba o auge do escândalo do Mensalão (2005), processo e julgamento (2011-2012), julgamento de recursos e prisão (2014). 
Foi possível também identificar algumas estratégias de linguagem utilizadas nos textos que evidenciam as intencionalidades da publicação, uma delas é a permanente desconfiança sobre o PT e seu governo em relação à corrupção, quando simbolizadas na figura de Dirceu.

Partimos da hipótese de que a revista Veja caracteriza José Dirceu como anti-herói em sua narrativa sobre o escândalo e desdobramentos. De acordo com Motta (2013) o antiherói é um personagem de caráter contraditório, bom e mau, perverso e protetor, rebelde e revolucionário, cínico e cruel, que se divide entre a comunhão e a oposição ao mundo.

A metodologia da análise foi baseada no estudo de personagens jornalísticas de Mesquita (2003), de alguns elementos da Análise Crítica da Narrativa elencados por Motta (2013) e da estrutura dos roteiros de cinema e da televisão, com base em Rodrigues (2014) e Vogler (2006). A interpretação teve o objetivo de extrair quais as funções exercidas pelo personagem (entre elas, a de anti-herói) nos episódios selecionados por Veja durante a cobertura sobre o caso.

A análise de narrativas é um método ainda pouco explorado do ponto de vista dos estudos de jornalismo. Como afirma Motta (2013), isso acontece pela resistência de profissionais e pesquisadores à ideia de que não caberia ao jornalismo "contar histórias" em função de valores da profissão como objetividade e imparcialidade.

O Mensalão, por exemplo, tem sido tema de diversas pesquisas acadêmicas na área de comunicação, orientadas principalmente pela análise de discurso e/ou de conteúdo dos veículos tradicionais: revistas, jornais, TVs e portais na internet, entre eles, a revista Veja, um dos objetos de análise do presente projeto. Como exemplo, temos a pesquisa de Guazina (2011) que analisou em sua tese de doutorado pela Universidade de Brasília UnB, o enquadramento das matérias sobre o Mensalão no Jornal Nacional da TV Globo. Entre as conclusões da autora, está a desqualificação da política e dos políticos na cobertura do telejornal principalmente em relação a José Dirceu, Roberto Jefferson, ao exdeputado federal José Genoíno e ao ex-tesoureiro do PT Delúbio Soares.

Araújo (2013), em dissertação de mestrado pela Universidade de Coimbra (Portugal), fez análise de discurso das reportagens das revistas Época e Veja sobre o julgamento do escândalo do Mensalão. Em seu estudo, Araújo (2013) concluiu que José 
Dirceu foi anti-herói do julgamento, um símbolo da corrupção do PT, que precisava ser combatido e punido. Segundo Araújo, quem assumiu a função de herói na cobertura das duas revistas foi o ministro Joaquim Barbosa, relator da AP 470. Era ele que teria a missão de combater a impunidade e a corrupção na política.

Guimarães et al (2004) também utilizaram a análise do discurso a partir de método comparativo das matérias publicadas nas revistas Carta Capital e Veja sobre o caso Waldomiro Diniz, que era assessor de José Dirceu na Casa Civil e foi exonerado em função de uma gravação recebendo propina para a campanha do PT ao governo do Rio de Janeiro em 2002. Os autores concluíram que as duas revistas deixaram de lado a pretensa objetividade jornalística e apresentaram suas versões dos fatos com o objetivo de orientar a assimilação e as interpretações dos leitores.

O papel exercido por José Dirceu na cobertura jornalística foi também tema do trabalho de Gonçalves, Souza e Renó (2006), que realizaram análise de discurso de matérias publicadas nos jornais Folha de São Paulo, Estado de São Paulo, Diário de São Paulo, Gazeta Mercantil, Valor Econômico e DCI nas edições do dia 17 de junho de 2005, no dia seguinte ao anúncio da saída de José Dirceu da Casa Civil no auge do escândalo do Mensalão. Sobre a forma como os jornais retratam José Dirceu, constatou-se que, para a Folha de São Paulo, ele seria um vilão, ligado a outros episódios de corrupção, como o caso Waldomiro Diniz; para o Estado de São Paulo, José Dirceu se apropriou de funções que deveriam ser exercidas pelo ex-presidente Lula; Para o Diário do São Paulo, o exministro sofre as consequências do escândalo e, segundo os jornais econômicos, o Mensalão seria um episódio político que não afetaria a economia.

Com base nesses estudos, podemos afirmar que a extensa cobertura sobre o escândalo do Mensalão evidenciou características da atuação da mídia que serão aprofundados na pesquisa: o jornalista como fiscalizador dos poderes, como cão de guarda (watchdog) e guardião da ética; além prevalência da desconfiança dos políticos e da política como apontam Traquina (2005), Waisbord (2000) e Guazina (2011).

Outra constatação é que os escândalos políticos não se constituem como fenômeno recente na história política brasileira. Porém, desde a redemocratização, tem crescido a importância dos escândalos na cobertura política nacional porque, após a Ditadura Militar 
(1964-1984), a imprensa brasileira mudou sua forma de ver e cobrir a política como apontam Martins (2005) e Rodrigues (2002). O que antes era proibido- a investigação do envolvimento de governantes ou parlamentares em casos de corrupção e a fiscalização da aplicação de recursos orçamentários, por exemplo - deixou de sê-lo com o fím da censura. Dessa forma, o Estado passou a não ter mais controle institucional sobre o que era divulgado pelos veículos de comunicação e o Congresso Nacional voltou a atuar durante a elaboração da então nova Constituição Federal, promulgada em 1988.

A configuração da cobertura política no Brasil começou a se redesenhar e o Parlamento influenciou decisivamente para isso porque senadores e deputados também passaram a ter mais liberdade no trato com os jornalistas, como destacam Guazina (2011) e Aldé, A. e Vasconcellos, F (2008).

Além disso, interlocutores de outros órgãos públicos, entre eles, o Ministério Público Federal - MPF e a Polícia Federal - PF que, com a redemocratização, passaram a investigar casos de corrupção e desvio de dinheiro público e tornaram-se fontes para a mídia. No âmbito do Congresso, também seria possível a criação de Comissões Parlamentares de Inquérito - CPI com poder para investigar os casos e convocar depoimentos de supostos envolvidos. De acordo com Nascimento (2007), desde 1989, aumentou a dependência dos jornalistas em relação ao Ministério Público com a imprensa e que, quando o órgão atua como fonte sobre suas próprias investigações, o jornalismo não é investigativo e sim sobre investigações.

Desde então, o papel dos partidos de oposição, com destaque para o Partido dos Trabalhadores - PT, fundado em 1980, também se fortaleceu nas disputas políticas e passou a ganhar atenção da grande mídia, mesmo esta sendo conservadora ao olhar de muitos intelectuais de esquerda. A visibilidade de Luiz Inácio Lula da Silva, líder sindical nas greves de metalúrgicos do ABC Paulista levo-o a disputar (e posteriormente perder) as primeiras eleições diretas após a Ditadura em 1989.

Segundo Conti (1999), Collor teve apoio da mídia em sua condução à Presidência da República. Os veículos de comunicação o destacavam como liderança jovem que prometia acabar com a corrupção e os gastos desnecessários de dinheiro público, imagem 
construída durante as eleições para o governo de Alagoas. "Foram anos em que a imprensa teve uma participação substantiva na vida política”, diz Conti (1999, p.9).

Mas os indícios de que Collor estaria envolvido em um esquema para a obtenção de dinheiro irregular de campanha, com a ajuda do responsável pelo caixa, Paulo César Farias, o PC, mudou o cenário político. Conti (1999) afirma que reportagens produzidas pelos mesmos veículos de comunicação que deram destaque ao presidente ainda candidato serviram de estopim para o movimento que o tiraram do cargo.

O caso, após investigações de uma Comissão Parlamentar de Inquérito - CPI, levou Collor ao impeachment em 1992 (ele também renunciou no mesmo ano para evitar a cassação), mas também foi um marco no jornalismo brasileiro de acordo com Waisbord (2000), quando se consolidou a atuação profissional dos jornalistas como cães de guarda (watchdogs) e fiscalizadores do poder político.

Mattos (2008) também destaca a importância da cobertura do impeachment para o jornalismo político no Brasil. A autora aponta que houve excessos na cobertura e a emergência do sensacionalismo. No entanto, esse contexto contribuiu para o posicionamento da mídia daquele momento em diante "fazer uso de sua nova liberdade para exigir maior transparência na política e a adoção de práticas mais éticas” (p.100).

O que se percebe, principalmente após o caso Collor, é um aumento da cobertura de escândalos e de denúncias, o que leva as narrativas a se fundamentarem em conflitos como categorias estruturantes (Motta e Guazina, 2010). Dessa forma, para contribuir e contextualizar a análise de narrativa, foi necessário estudar as características dos escândalos político-midiáticos, seus ciclos e consequências, além da atuação da mídia nesses casos, conforme teoria elaborada por Thompson (2002).

O autor (2002) ressalta que "os escândalos midiáticos são eventos narrativos prolongados em contínua evolução" (p.107) até o esgotamento de informações sobre o caso ou da punição imediata dos envolvidos.

Segundo Motta (2013), que elaborou uma proposta de Análise Crítica da Narrativa, a partir dos estudos linguísticos da Narratologia, a narrativa jornalística pode se configurar em uma única reportagem ou notícia que tratem, por exemplo, de dramas humanos e 
tragédias pessoais "cuja estrutura fechada se assemelha a um conto" (p.95). Motta cita a classificação de Tuchman (1978) que chama de soft news as notícias caracterizadas por uma linguagem, como ressalta Motta (2013), “quase literária ou quase ficcional (...) em que o repórter ganha liberdade para imaginar, criar e sugerir no texto efeitos estéticos de sentido" (p.95). No jargão jornalístico as soft news são chamadas de "notícias frias", quando geralmente não tem urgência de serem publicadas. No caso da análise de hard news (notícias duras, factuais), como é o caso da cobertura de escândalos, Motta (2013) recomenda ao analista que junte as matérias a fim de compor a intriga porque, diferente da literatura, a narrativa jornalística não tem começo, meio e fim.

Sobre a questão, também afirma Traquina (1993): “as notícias registram as formas literárias e as narrativas utilizadas pelos jornalistas para organizar o acontecimento" (p.176). Para Tuchman (1978), “as notícias não refletem a sociedade. Elas ajudam a constituir um fenômeno social partilhado, dado que, no processo de descrever um acontecimento, as notícias definem e dão forma ao mesmo" (p.184). A autora também aponta que os jornalistas possuem maneiras específicas de contar histórias e essas narrativas possuem códigos reconhecidos pelos destinatários.

Segundo Traquina (1993) há também os valores-notícias que fazem parte da cultura profissional do jornalista e compõem o processo de produção jornalística. Uma das etapas é a seleção dos acontecimentos "sugerindo o que deve ser realçado, omitido e prioritário na construção da notícia" (p. 79).

Já a predominância de conflitos na cobertura política está relacionada com as disputas internas do campo político. Essa competição também é definida por Schmitt (1992) como relação amigo-inimigo. Seguindo os preceitos de Bourdieu (1998), Guazina (2011) define campo como um conjunto de saberes e práticas que se estabelecem ao longo do tempo. Dessa forma, podemos afirmar que as disputas no campo político abastecem a cobertura jornalística, pois ainda segundo Guazina (2011), as lutas se estabelecem porque os campos querem conservar sua posição. Por isso, a mídia, quando funciona como fiscalizadora dos poderes, favorece a disputa entre campo jornalístico e campo político. Sendo que o campo jornalístico também possui disputas internas. 
Entre os exemplos, estão as notícias sobre o embate entre governo e oposição ou, nos casos de investigação, quando existe o acusador e o acusado, como aconteceu entre o então deputado federal Roberto Jefferson (delator no caso do Mensalão) e José Dirceu acusado por ele de ser o mentor do esquema.

Por outro lado, Traquina (1993) define a dramatização como reforço do lado emocional e da natureza conflitual. Na visão de Lima (2000), os embates facilitam a dramatização da notícia que tem principalmente o interesse mercadológico de atrair a audiência. Em função disso, a cobertura é marcada por assuntos carregados de rivalidade, suspense, vencedores e perdedores.

Dentro do conjunto de valores-notícias, Traquina (1993) também destaca a personalização. Essa categoria é vista aqui como elemento da narrativa jornalística que pretende ser aprofundado com o estudo sobre a construção do personagem José Dirceu no contexto do escândalo político-midiático do Mensalão. Entre os objetivos, está identificar quais suas funções no encadeamento dos fatos narrados nas matérias de capa da revista Veja sobre o caso entre 2005 e 2014.

Todorov (1971) conceitua encadeamento como a justaposição de diferentes histórias: quando uma acaba, outra começa. "A unidade é assegurada neste caso por uma semelhança na construção de cada uma das histórias" (p. 236). Todorov (1971) também discorre sobre encaixamento, que é a "inclusão de uma história no interior de outra" (p.236). No caso da narrativa jornalística, a identificação desses elementos pode ser tornar mais difícil, segundo Motta (2013), pois os fatos são contados de forma separada nas matérias jornalísticas, diferentemente da narrativa literária que tem começo, meio e fim. Portanto, segundo o autor, é necessário que se junte as peças para compor a estrutura integral dos enredos, o que podemos caracterizar como sequência das edições de Veja ao longo do período que será estudado.

Já a personagem é quem realiza a ação no curso das narrativas. Segundo Gancho (2002), o personagem é responsável pelo desempenho do enredo. O protagonista é uma classificação de personagem, a exemplo de José Dirceu nas matérias de Veja que serão analisadas, e de acordo com Abdala Júnior (1995), os conflitos se desenvolvem em torno dele que é "o ponto de referência para as alianças e confrontos entre os personagens" (p. 
44). Para Reis (2006), os personagens ocupam lugar de destaque porque é por eles que os leitores se interessam e, neles, buscam respostas.

Mesquita (2003) aponta que a criação de personagens é uma atividade estruturante das práticas e do discurso jornalístico, que se assemelha ao valor-notícia da personalização proposto por Traquina (1993). O autor explica que as abordagens sobre personagens podem ser operativas em áreas não-ficcionais como a reportagem, inclusive na caracterização de políticos. Motta (2013) acrescenta que, em narrativas fáticas, até as personalidades públicas não podem ser consideradas como pessoas reais, e sim figuras do discurso.

Na visão de Rodrigues (2013), a caracterização dos personagens é essencial para a estrutura da narrativa e a construção da trama, pois são capazes de tornar o enredo marcante. Segundo ela, toda narrativa seriada e fílmica, por exemplo, "precisa estabelecer um protagonista, um objetivo do protagonista e um obstáculo entre o personagem e o que deseja alcançar” (p.16). Vogler (2006) aponta que os narradores escolhem seus personagens para “criar experiências dramáticas reconhecíveis por todos" (p.48). Ao longo das análises, observamos que Veja se utiliza da linguagem simples e coloquial das narrativas de TV e do cinema em suas matérias, por isso, os preceitos de Rodrigues (2014) e Vogler (2006) foram incluídos como referencial teórico-metodológico.

Nas doze matérias analisadas, o personagem José Dirceu é tratado por Veja como protagonista da narrativa em função do ex-ministro ser acusado de ter chefiado o esquema do Mensalão. Para isso, outros elementos narrativos também serão identificados na interpretação, tais como: enredos, episódios, recursos dramáticos, descrição de ambiente, tempo, espaço e de personagens secundários que influenciam nas ações atribuídas a Dirceu.

A partir dos dados apresentados na introdução, foi possível traçar uma linha histórica, teórica e metodológica que constam nas páginas seguintes. O primeiro capítulo trata do imaginário da objetividade e como o jornalismo influenciou na desconfiança na política principalmente nas democracias liberais que elegem representantes por meio do voto, como acontece no Brasil, e se depositam mais expectativas no político e na sua conduta moral do que na sua competência técnica. No segundo, aprofundamos e relacionamos a Teoria do Escândalo de Thompson (2002) com as características percebidas 
no caso Mensalão, além de destacar como o escândalo político-midiático pode afetar a reputação do político envolvido.

No terceiro, foi realizado um levantamento histórico sobre a revista Veja e seu papel no jornalismo político brasileiro. Posteriormente, fizemos também o resgate sobre a cobertura da revista em relação a José Dirceu desde o movimento estudantil de 1968, eleições de 2002 e, finalmente, sobre o Mensalão. Por último, foi elaborada uma linha histórica sobre o caso, enumerando as edições que a Veja dedicou ao assunto e quais delas foram dedicadas ao ex-ministro.

No quarto, foram estabelecidos aspectos teóricos, baseados nos estudos já mencionados, onde foram explicados os procedimentos de análise das matérias selecionadas e da execução do projeto. Ao fim, no capítulo 5, realizamos a análise das doze edições e as conclusões a respeito dos resultados. 


\section{CAPÍTULO I}

\section{DESCONFIANÇA NA POLÍTICA: A INFLUÊNCIA DO JORNALISMO}

\section{1 - O jornalismo moderno e o mito da objetividade}

Para entendermos como se consolidaram as características do jornalismo contemporâneo e como se estabeleceu a vigilância e a desconfiança na política, em especial, nos regimes democráticos em crise, a exemplo do Brasil, é necessário que se faça um resgate histórico das transformações recorrentes da modernização da imprensa e da profissão de jornalista que levaram a elas. Após o processo de industrialização dos jornais que começou no século XIX, também houve o advento do rádio e da televisão no século XX. Esses meios contribuíram decisivamente para alterar a relação entre políticos e a sociedade, que até aquele momento dependia do contato pessoal, segundo Thompson (2002). Hoje, a internet proporciona outros elementos, entre eles, a interação dos cidadãos com os políticos mesmo à distância, como aponta Tavares (2014), e a publicação em tempo real de posicionamentos político-ideológicos nas redes sociais.

De acordo com Traquina (1993) o jornalismo se profissionalizou com o desenvolvimento do capitalismo a partir do século XIX, principalmente nos Estados Unidos e Europa, com a "industrialização, a urbanização, a educação em massa, o progresso tecnológico e a emergência da imprensa como mass media" (Traquina, 1993, p.20). O autor explica que, quando a tiragem das edições aumentou proporcionalmente ao número de leitores, os jornais se constituíram como empresas e passaram a diferenciar notícia de propaganda. Ortega e Humanes (2000) completam que esse período foi marcado pela modernização dos parques gráficos e contratação de profissionais que se dedicariam em tempo integral à redação "repórteres, escritores, correspondentes e colunistas" (p.98).

Na visão de Ortega e Humanes (2000), baseados em Max Weber, a imprensa, no formato de empresa capitalista que visa o lucro, direcionou seus interesses para o mercado e à dupla clientela: leitores e anunciantes. Essas mudanças influenciaram na profissionalização do jornalista, que passou a exercer suas atividades de forma majoritariamente autônoma, principalmente em países onde se garante a liberdade de 
expressão. Anteriormente, os jornais dependiam de poderes políticos e econômicos e quase sempre precisavam apoiar claramente este ou aquele grupo político em seus conteúdos e linhas editoriais.

Os autores consideram que partir da industrialização algumas características se diferenciavam da fase anterior: informação mais abundante, prioridade para as notícias factuais, notícias mais exatas, completas, objetivas e neutras, além do aumento de conteúdos internacionais. "O processo de profissionalização começa quando uma ocupação se constitui em um campo específico de atividade, então os pioneiros em novas técnicas se ocupam de ensinar os principiantes e estabelecem as escolas de formação" (Ortega e Humanes, 2000, p.103).

Pela definição de Bourdieu (2005), o que Ortega e Humanes (2000) chamam de campo específico de atividade pode ser considerado como o campo jornalístico que estabelece relações complexas com outros campos, entre eles o político, científico e social. A constituição de um campo depende da reunião de saberes e práticas que vão se consolidando ao longo do tempo. Traquina (1993) lembra que o campo jornalístico reúne um grupo que se especializou, profissionalizou-se e domina linguagem específica. Dessa forma, possui autoridade para exercer a função, código de ética e reconhecimento público, gerando assim, a valorização e a identidade profissional. "As notícias refletem o ethos especializado da comunidade jornalística e são modeladas pelas suas estruturas e processos" (Traquina, 1993, p. 23). Guazina (2013) se utiliza de Geertz (2008) para conceituar o ethos como tom, caráter, estilo e expressão de determinada cultura.

A identidade profissional e os valores compartilhados pelos jornalistas foram sendo moldados de acordo com a rotina das redações, a partir também da exigência das empresas em conquistar credibilidade entre leitores e anunciantes para aumentar os lucros. Mesquita (2003) define a objetividade como a construção resultante da nova estratégia comercial da imprensa: "o jornal procura manter uma atitude imparcialmente objetiva, dirigindo-se a todos, e não a um grupo de leitores ideologicamente afins, necessariamente mais restrito" (p.208). Mesquita (2003) acrescenta que a "sacralização" da objetividade se impôs como valor jornalístico no século XX, quando se fazia necessária a diferença entre atividade jornalística e a de relações públicas. 
O autor (2003) exemplifica que a objetividade para os anglo-americanos está entre as obrigações do jornalista, segundo seus códigos de ética. Já na Europa, especialmente na França, os jornalistas acreditam na existência de honestidade e não de objetividade. Ele também aponta que a ideia mais global do conceito de objetividade pode estar relacionada com o jornalismo feito pelos veículos generalistas (agências, rádios, TVs, etc.) que precisariam manter o equilíbrio, a neutralidade e a contenção: "nessa perspectiva esse ideal recusaria aos jornalistas a cidadania ao transformá-los em observadores moralmente descomprometidos" (p.209).

Os jornais norte-americanos, por exemplo, elaboraram os primeiros manuais de redação na década de 40, quando o chamado jornalismo "isento e moderno" predominou em relação ao opinativo e o de opinião, como aponta Biroli (2010). Dessa forma seguia-se a lógica industrial e capitalista baseada no controle e disciplinamento: "normatização no jornalismo, composta por técnicas de organização do trabalho e de constituição do jornalista como trabalhador produtivo" (p. 195).

Como destaca Biroli (2010), os manuais de redação dos jornais norte-americanosalguns foram adaptados por grandes jornais brasileiros como a Folha de São Paulo e $O$ Globo - já deixavam clara a centralidade da aliança entre espaço e tempo, orientando os repórteres a escrever matérias mais curtas e também manter distância emocional, partidária e ideológica dos assuntos apurados.

Pompeu de Sousa, um dos pioneiros do curso de Jornalismo da Universidade Federal do Rio de Janeiro - UFRJ e autor da proposta de criação da Faculdade de Comunicação da Universidade de Brasília - UnB na década de 1960, redigiu o primeiro Manual de Redação utilizado por um jornal brasileiro, o Diário Carioca, em 1950. Segundo Mendez (2006), ele reuniu todos os conhecimentos adquiridos com suas pesquisas sobre o jornalismo norte-americano e introduziu o lead, pirâmide invertida, entre outras regras, no fazer jornalístico do jornal.

Sobre isso, completa Traquina (1998): "o fator tempo condiciona todo o processo de produção das notícias porque o jornalismo é marcado por horas de fechamento" (p.37). Para ele, é impossível separar o imediatismo do jornalismo contemporâneo, mas a 
objetividade ainda causa polêmica tanto na comunidade profissional, quanto no meio acadêmico.

Traquina (1993) lembra que critérios de noticiabilidade - o conjunto de valores-notícias partilhados na comunidade jornalística - foram estabelecidos ao longo da construção do campo jornalístico, não só após o processo de industrialização dos jornais "critérios e operações que fornecem aptidão de merecer um tratamento jornalístico, isto é, produzir valor como notícia” (p. 63).

No século XVII, aponta Traquina (1993), os principais critérios de noticiabilidade eram as tragédias, informações sobre pessoas conhecidas, situações insólitas e bizarras, trocas comerciais, guerras e fenômenos naturais. A conclusão do estudo é que a essência das notícias pouco mudou em relação aos dias atuais principalmente em relação à predominância do negativismo e do inesperado.

No caso do jornalismo político, assunto a ser detalhado mais adiante, os valores-notícia enumerados por Traquina podem ser observados em diferentes coberturas: conflito, a inversão de valores, infração e escândalo. Segundo ele, a controvérsia também é considerada entre os procedimentos padrão na rotina das redações, o que leva a crer que o jornalista deve ser imparcial, neutro e objetivo. "Os jornalistas apresentam os dois lados da questão, sem tomar partido (...) mas para além da controvérsia estão os atores e pontos de vista políticos que os jornalistas e valores dominantes rejeitam como marginais" (p.87).

Além disso, Biroli (2010) aponta que, mediante a profissionalização do jornalismo e do funcionamento das redações, se desenvolveu uma visão idealizada de objetividade, isenção e imparcialidade, e também um discurso falacioso sobre ética. "O valor objetividade pode ser mobilizado para a proteção do próprio jornalista diante de práticas de manipulação, falseamento ou silenciamento das empresas” (p.218).

Tuchman (1993) define a rotina produtiva em torno da objetividade como "ritual estratégico". A socióloga enumera os procedimentos que garantem ao jornalista e à empresa de que não serão, por exemplo, processados por difamação. Segundo ela, a objetividade tornou-se uma justificativa para ambos se protegerem desses riscos. 
Entre os procedimentos enumerados por Tuchman ao longo de sua pesquisa com observação participante em redações de jornal nos Estados Unidos, estão: o uso de aspas (o jornalista desloca para as fontes e entrevistados a opinião que gostaria de dar sobre o assunto); a busca pela exatidão das notícias dentro do pouco tempo até o fechamento da edição (evitaria correções que podem atrasar a circulação dos jornais e causar prejuízos para a empresa) e a apresentação de possibilidades conflituais.

Por exemplo, mesmo diante de uma informação não comprovada, a partir de um depoimento ou denúncia, o jornalista se utiliza da controvérsia - ouvir dois lados opostos para que o leitor tire as suas conclusões. "Os jornalistas veem as citações de opiniões de outras pessoas como forma de prova suplementar. Ao inserir a opinião de alguém, eles acham que deixam de participar da notícia” (Tuchman, 1993, p.81).

Há outra questão tratada por Tuchman (1993) sobre as tentativas de separar as notícias cotidianas, com características relacionadas à objetividade e exatidão, dos textos de análises dos assuntos. Isso acontece principalmente na cobertura política. Durante a pesquisa, Tuchmam relata que observou um editor que costumava retirar trechos das matérias de um repórter de política com opiniões e previsões, inclusive aquelas que fugiam completamente do senso comum que, segundo ela, desempenha um papel importante na avaliação do que é notícia "uma vez que o conteúdo de uma notícia é composto de numerosos fatos e o senso comum determina se uma informação pode ser aceita como fato" (p. 87).

Tanto Tuchman (1993), quanto Mesquita (2003) e Alsina (2005) enumeram as dificuldades de os jornalistas serem inteiramente objetivos no exercício da profissão. A própria elaboração do lead quando, no universo de informações apuradas para uma matéria, o repórter precisa selecionar o que é mais importante para iniciar o texto, trata-se de um critério subjetivo.

Para Alsina (idem, p. 239), “O próprio modelo liberal da imprensa é quem limita a objetividade" Segundo o autor, os jornalistas precisam interpretar os acontecimentos, não só conferindo valores, mas também selecionando informações e fontes ouvidas, qualidade e quantidade das notícias de acordo com a linha editorial do veículo. "Explicando um 
acontecimento, no sentido de torná-lo compreensível, o jornalista o registra em um modelo familiar do conhecimento humano" (p. 239).

Em contrapartida, Mesquita (2003) conclui que a objetividade também não pode ficar totalmente excluída como referência para o jornalismo se diferenciar das demais narrativas: literatura, cinema e teatro. $\mathrm{O}$ autor explica que isso acontece principalmente porque existe um contrato de recepção celebrado entre o jornalista e o destinatário que espera do jornalista uma "conduta de objetividade" ou "compromisso com o real" assuntos que serão detalhados no capítulo teórico metodológico.

A partir das observações acima, podemos considerar que os valores-notícias compartilhados pelos jornalistas e o mito em torno da objetividade, que se desenvolveu ao longo da consolidação do campo jornalístico, foram fundamentais para a redefinição do jornalismo político praticado no Brasil no processo de redemocratização após a Ditadura Militar (1964 - 1984). A própria busca pela credibilidade, mesmo com base nos interesses mercadológicos das empresas, também contribuiu para esse tipo de cobertura como vemos em Guazina (2011).

A seguir, inicia-se a análise a respeito da crise nas democracias representativas, principalmente nos países em desenvolvimento, a exemplo do Brasil, e suas consequiência como a desconfiança na política e nos políticos que influenciou a cobertura jornalística.

\section{2 - A Crise na Democracia Representativa e a Frustração de um Modelo}

Após 20 anos de Ditadura Militar (1964-1984), milhares de brasileiros ocuparam as ruas do país pedindo eleições diretas. A campanha ganhou adesão de políticos contrários ao regime, entre eles, os futuros presidentes da República Fernando Henrique Cardoso e Luiz Inácio Lula da Silva, além de artistas, atletas, músicos e representantes da sociedade civil.

Votar para presidente, após um período de repressão às vontades populares, parecia ser o mais importante e urgente naquele momento como afirma Markun (2004). Após a rejeição da emenda Dante de Oliveira, que previa o voto direto, não ser aprovada no Congresso, Tancredo Neves foi eleito pelo Colégio Eleitoral, sendo o primeiro presidente civil dos últimos 20 anos. Ele morreu antes da posse e assumiu o vice José Sarney. Só em 
1989, o eleitor brasileiro pode escolher o presidente por meio do voto direto e antes de disso, em 1988, uma nova constituição foi promulgada.

De 1988 até os dias atuais não ocorreram significativas mudanças no modelo democrático brasileiro: as eleições presidenciais para presidente, governador, prefeito e senador são majoritárias; para o poder legislativo, deputados estaduais e federais e os vereadores são eleitos de forma proporcional.

Segundo o Tribunal Superior Eleitoral - TSE o sistema consiste em "saber quais foram os partidos políticos vitoriosos para, depois, dentro de cada agremiação partidária que conseguiu um número mínimo de votos, observar quais são os mais votados. Encontram-se, então, os eleitos. Esse, inclusive, é um dos motivos de se atribuir o mandato ao partido e não ao político".

De acordo com Rosavallon (2008) o poder do voto direto ganhou aceitação imediata nos modelos de governos democráticos liberais. A ideia de que as pessoas têm o poder de escolha não seria questionada, pois a prevalência do voto da maioria é a essência da democracia em contraste aos regimes autoritários.

Porém, Rosavallon (2008) destaca que as regras majoritárias são difíceis de entender em termos sociológicos e que as eleições democráticas conflitam entre o princípio da justificação e o da técnica de decisão. A ideia central é escolher os representantes para o interesse geral. Porém, o sufrágio universal desenvolveu um sistema de barganha e a atender interesses de apenas uma parcela dos votantes. Na visão do autor, pode-se concluir que o voto majoritário não é garantia de um governo honesto.

A crise de representatividade começou nos anos 80 , quando houve um colapso na legitimidade eleitoral e burocrática com a ascensão do neoliberalismo, em especial, em alguns países da Europa. Na visão de Rosavallon (2008), ao longo de décadas, apenas o voto não foi suficiente para consolidar a confiança dos eleitores em seus governantes. Unido a isso, perdeu-se também alguns critérios de julgamento da qualidade da democracia no país, uma espécie de acomodação dos representados.

Portanto, as novas formas de democracia precisam ser elaboradas, com vistas à descentralização de poder. O modelo tradicional de voto majoritário dos países acabou por 
limitar a expressão popular. Rosavallon (2008) completa que, apesar da democracia direta significar o voto da maioria, esses eleitores não têm participação na democracia indireta, ou seja, nas decisões dos políticos eleitos. Conforme o autor, há tensão entre as duas modalidades e são necessárias autoridades regulatórias independentes para garantir a legitimidade da imparcialidade de atuação dos órgãos públicos.

Rosavallon (2008) dá o exemplo do Orçamento Participativo em Porto Alegre (Brasil) como medida de participação dos cidadãos em atos de governo. É uma forma de fiscalizar quem elegeram, uma democracia aberta, transparente e que mantém regular diálogo com a sociedade civil. Uma tendência que se iniciou nos anos 90. Também é capaz de reduzir a possibilidade de populismo, uma das consequências da concentração de responsabilidades em um político e fazer com que os cidadãos entendam a natureza da política.

O processo da crise de representatividade trouxe descrédito à política como descrevem Chandhoke (2005) e O'Donnel (1991). Ambos realizaram pesquisas sobre países (Índia e os da América Latina, respectivamente) que enfrentam graves problemas sociais mesmo com a implantação de modelos democráticos que dependem do voto, porém, não promoveram de forma eficaz a participação popular na formulação de políticas públicas.

A democracia participativa que seria um passo além da democracia delegativa, que concentra poder e responsabilidades nos políticos, segundo O'Donnel (1991). A democracia representativa continua dependendo do voto, não tira sua importância, mas a participação popular poderia contribuir para que os eleitores qualifiquem suas escolhas baseadas no interesse coletivo e não particular.

Em paralelo ao desenvolvimento da democracia delegativa, surgiram outros poderes de supervisão, que não estão relacionados diretamente pela participação popular, enumerados por Rosavallon (2008) e descritos a seguir.

'Cinco tipos existem hoje: o controle parlamentar do executivo, combinado com poderes de investigar; opinião pública, que é polarizada e expressa de uma forma difusa através da mídia; intervenção crítica por partidos da oposição; movimentos e organizações de cidadãos social; e ad hoc instituições democráticas" (ROSAVALLON, 2008, p.301). 
Chandhoke (2005) realizou pesquisas na Índia para medir o grau de confiabilidade na política após a consolidação do regime democrático. Uma de suas conclusões é que, apesar do país se mobilizar para participar das eleições, a população indiana não obteve significativo retorno em forma de políticas públicas que considerassem suas necessidades básicas.

A decepção, causada pela manutenção da pobreza extrema, da fome, da falta de saneamento básico, da educação precária, da doença e da desigualdade de oportunidades, provocou uma espécie de descrédito relativo aos políticos e partidos que os eleitores escolheram para representá-los na esfera do poder.

Uma das constatações de Chandhoke (2005), ao fim da pesquisa, é que o nível desse descrédito na vontade política é tão alto que afeta até os grupos da sociedade civil e organizações não governamentais que, teoricamente, existem para ajudar a população a resolver problemas quando os órgãos públicos não os alcançam. "Os partidos políticos esgotaram a sua capacidade de representar as aspirações de seus colégios eleitorais, tornaram-se hierárquicos, burocráticos e rígidos, e eles tendem a seguir a lógica política e impulso do poder" (p.311).

Segundo a autora, outro motivo para o descrédito, advém da democracia representativa não oferecer estímulos aos cidadãos para participarem diretamente de fóruns ou debates ligados aos processos de tomada de decisão ou planejamento de políticas públicas. A única função dos eleitores é conferir consentimento sobre as escolhas dos outros. "Claro que há muito boas razões para isso, o principal é o tamanho e a complexidade das sociedades modernas, o que torna a democracia direta ou face a face uma possibilidade remota" (p.310).

Conforme Chandhoke (2005), a institucionalização generalizada do sistema partidário competitivo parecia ter resolvido o dilema da democracia no século XX, que seria a impossibilidade de estabelecer uma relação entre o cidadão e o Estado nas sociedades grandes e complexas. Mas, segundo a pesquisa, essa transição não aconteceu na Índia de forma satisfatória: $41 \%$ dos entrevistados disseram que suas necessidades básicas, os levariam a ter uma vida de dignidade não foram atendidas. "Pois não só são representantes, deveriam mediar a relação entre o Estado e o cidadão, não só eles são 
esperados para [re] apresentar os interesses dos seus eleitores em fóruns de formulação de políticas" (p.313).

Para a autora, todo governo democrático é moralmente obrigado a assegurar uma vida digna para o povo, atender suas necessidades e apresentar fielmente os interesses para que os seus constituintes obtenham isso. Caso isso não aconteça, o cidadão comum vai, cada vez mais, tratar a política e os políticos como irrelevantes, pois sem condições minimamente dignas, essas pessoas não conseguem nem prosseguir com seus planos de vida, não podem fazer nada. "A experiência de democracia formal da Índia mostra-nos que os representantes de partidos parecem fazer pouca coisa para articular o caso das camadas mais pobres da sociedade nos fóruns de decisão política" (p.316).

Chandhonke (2005) completa que além de não conseguirem cumprir a responsabilidade para com as pessoas, os partidos políticos se degeneraram rapidamente para máquinas sedentas de poder, não representativos e corruptos. $\mathrm{O}$ autor usa como exemplo o Partido do Congresso na Índia que não conseguiu evitar a explosão de descontentamento político. "Dada a incapacidade do partido para satisfazer aspirações e resolver problemas, novos grupos que entram na arena política recorreram à agitação e à violência para pressionar por suas exigências sobre o Estado" (p.319).

Dessa forma, diz Chandhoke (2005), esses novos grupos apareceram fora da esfera política partidária e isso reforçou a crença de uma parcela da população, principalmente a mais pobre, de que o sistema partidário não deu as respostas necessárias no quesito representar demandas. "Mesmo quando as pessoas se aproximam do governo para resolver os seus problemas as pessoas preferem ter a ajuda de conhecidos da vizinhança do que a de partidos políticos ou de qualquer outra organização" (p.322).

A própria determinação do sistema para a manutenção de poder contribui para o afastamento dos eleitos de seus eleitores, algo que tem acontecido no Brasil e afetou o Partido dos Trabalhadores - PT, dependente de alianças até com agremiações consideradas de direita para permanecer na Presidência da República. A tendência do representante é adquirir uma grande quantidade de autonomia, agregar interesses pluriais e conflitantes em relação ao que está sendo representado. "Os representantes peneiram interesses articulados, 
selecionam aqueles que eles consideram digno de representar, priorizam as agendas que aparecem mais viáveis para eles sobre os outros" (CHANHOKE, 2005, p.324)

De acordo com a autora, os representantes, portanto, não devem se afastar tanto dos desejos objetivos do povo. Caso esse desvio persista, precisam a explicar isso para seus constituintes em forma de prestação de contas. Segundo a pesquisa de Chandhoke (2005), a situação social na Índia é tão caótica que a nenhuma organização tem sido capaz de inspirar confiança nas pessoas ou mesmo pressionar por demandas que o governo é obrigado a fazer. "A democracia formal e legal permanece no processo dissociada da democracia social e econômica" (p.328).

Uma das consequências dessa relação de afastamento entre o representante e o representado, além do descrédito na capacidade dos políticos e dos partidos por parte dos eleitores, é o enfraquecimento da democracia: quando os cidadãos recorrem a contatos personalizados para resolver seus problemas, pode-se abrir brecha para o patrimonialismo e para desmobilização popular em nome de objetivos comuns. "Dependência evidente em laços pessoais podem levar à consolidação das relações patrão-cliente, o que pode revelarse profundamente antidemocrático, bem como isolar as pessoas umas das outras" (CHANDHOKE, 2005, p.328).

O'Donnel (1991) propõe uma tipologia de democracias dentro dos padrões da execução de políticas públicas e considera que o modelo adotado nos países que enfrentaram regimes autoritários culminou em uma democracia delegativa. Um dos motivos é que a heranças dessas ditaduras foram profundas crises sócio-econômicas, como foi o caso do Brasil.

\footnotetext{
"Mas essas democracias não são - nem parecem estar caminhando pra isso democracias representativas; elas apresentam um conjunto de características que me deixam tentado a chamá-las de democracias delegativas (...) a profunda crise social e econômica que a maioria desses países herdou de seus antecessores autoritários multiplica poderosamente as consequências de certas concepções e práticas que conduzem na direção da democracia delegativa e não representativa" (O'DONNEL, 1991, p.26).
}

Para o autor, prevalece o discurso organicista e individualista, que isola o presidente da República, o responsável pelas decisões certas ou erradas, principalmente quando se trata de política econômica. 
"Quem ganha uma eleição presidencial é autorizado a governar o país como lhe parecer conveniente e, na medida em que as relações de poder existentes permitam, até o final do seu mandato. $O$ presidente é a encarnação da nação, o principal fiador do interesse nacional, o qual cabe a ele definir. O que ele faz no governo não precisa guardar nenhuma semelhança com o que ele disse ou prometeu durante a campanha eleitoral" (O'DONNEL, 1991, p.30)

O mito da delegação legítima é sustentado pelo voto da maioria, que independente de suas formações políticas e identidades, pode escolher a pessoa que considera ser mais adequada para dirigir o país. "Depois da eleição, espera-se que os eleitores/delegantes retornem a sua condição de espectadores passivos, mas quem sabe animados, do que o presidente faz" (O'DONNEL, 1991, p.31).

O'Donnel (1991) também defende a partilha de responsabilidades, ainda mais porque, na democracia delegativa, o presidente não seria obrigado a prestar contas do mandato de forma horizontal.

O autor faz uma análise histórica sobre o que chama de "onda de democratização" que tomou conta de países europeus derrotados na Segunda Guerra Mundial. Completa que as expectativas econômicas da população européia eram moderadas em comparação à América Latina.

\footnotetext{
"A maioria desses países (da América Latina) herdou uma situação difícil do regime autoritário anterior (...). Inflação extrema, estagnação econômica, uma profunda crise financeira do estado, uma enorme dívida pública externa e interna, e uma acentuada deteriorização das políticas e dos serviços sociais públicos são aspectos dessa crise" (p.34).
}

O'Donnel (1991) destaca que no Brasil, na Argentina e no Peru, os governos fizeram uso da política dos pacotes para tentar estabilizar a economia após os regimes totalitários. Porém, “essas políticas não resolveram nenhum dos problemas herdados; ao contrário, é difícil encontrar um único problema que não tenha se agravado" (p.34).

O aprofundamento da crise cria um cenário de centralização de poder em cima do presidente da República, alguns eleitos como salvadores da pátria, fortes e corajosos. No caso do Brasil, Fernando Collor de Melo, primeiro presidente eleito após a Ditadura se apresentou à mídia como o "caçador de marajás", termo utilizado para designar quem se beneficiava do Estado para interesses privados. De acordo com Conti (1999) o legado de Collor foram acusações de corrupção e planos econômicos que fracassaram que o levou a sofrer impeachment. 
"É suficiente mencionar que quanto mais profunda a crise e mais longa a crise e quanto menor for a confiança em que o governo será capaz de resolvê-la, mais racional se torna para todos agir (...) segue-se uma maior desarticulação e enfraquecimento e corrupção do aparelho do estado (...) com o pressuposto de que todos os outros farão o mesmo" (p.36).

Existe, conforme O'Donnel (1991) "uma marginalização dos partidos políticos e do Congresso das decisões mais importantes do país (...) um Congresso que não se sente politicamente responsável por políticas públicas que começaram por ignorá-lo (...) são um fator importante no acentuado declínio do prestígio de todos os partidos e políticos” (p.37).

Portanto, conforme os autores relacionados, as crises na democracia representativa na América Latina e no Brasil refletem na forma como a população passou a desconfiar da política. Ao mesmo tempo, tivemos as transformações na estrutura das redações, do próprio jornalismo e nas coberturas dos acontecimentos políticos como veremos a seguir.

\section{3 - Brasil: mídia e declínio da confiança na política}

No Brasil, o processo de modernização e profissionalização dos veículos de comunicação ganhou força na década de 50, quando, de acordo com Laurenza (2008), o país passou por mudanças radicais nas regras políticas e econômicas. Matos (2008) acrescenta que os veículos de comunicação brasileiros demoraram a estabelecer as características atuais na cobertura política, entre elas, as denúncias de corrupção e a vigilância dos jornalistas, porque o país viveu em um ambiente político conturbado até o fim da Ditadura Militar (1964-1984).

Durante o processo de democratização, em 1984, a "Folha de São Paulo" também propôs um novo modelo de jornalismo após a Ditadura Militar, o "Projeto Folha", idealizado por Otávio Frias Filho. Como descreve Villaméa (2008), após o engajamento político da Folha de São Paulo na campanha pelas "Diretas Já! ”, frustrada pela derrubada da emenda Dante de Oliveira pelo Congresso Nacional, o jornal "decidiu restringir a opinião aos editoriais e colunas assinadas em busca de um jornalismo crítico, pluralista, apartidário e moderno" (p.254).

A partir de então, os manuais de redação brasileiros fortaleceram a orientação ao jornalista de ouvir os diversos lados de uma história, caracterizado por Tuchman (1993) como parte do ritual estratégico da objetividade. Villaméa (2008) diz que no período da redemocratização, ao longo de todos os acontecimentos que levaram ao fim da ditadura 
militar como a morte de Vladimir Herzog (1975) e o atentado no Riocentro (1981), "uma certeza vigorava entre os jornalistas: a busca pelo o que está por trás dos fatos" (Villaméa, 2008, p.257).

Dois momentos foram marcantes para estabelecer as características atuais da cobertura política e do ethos jornalístico entre os profissionais de imprensa brasileiros na visão de Guazina (2011), Matos (2008), Villaméa (2008) e Rodrigues (2002). Primeiro, a constituinte de 1988, que evidenciou a diversificação da arena política no país: vários partidos de esquerda, direita e centro, além do reaparecimento dos movimentos sociais, reprimidos da Ditadura.

A nova Constituição, como lembra Rodrigues (2002) e Guazina (2011) deu autonomia e independência para o Ministério Público, tanto os estaduais, quanto o Federal, de investigar casos de corrupção nos altos escalões dos Poderes, função que foi prejudicada pela Ditadura Militar. Mesmo processo se deu com a Polícia Federal. No âmbito democrático, aumentou também a dependência dos jornalistas às fontes desses órgãos para garantir matérias exclusivas. "A imprensa começou a entrar numa era que mudaria profundamente sua relação com a sociedade" (Villaméa, 2008, p.271).

O outro momento, considerado ainda mais decisivo por Waisbord (2000), foi o escândalo que levou Fernando Collor de Mello, o primeiro presidente eleito por eleições diretas após a Ditadura Militar no Brasil, a sofrer impeachment, em 1992, por favorecimento financeiro irregular durante a campanha eleitoral com a ajuda do tesoureiro Paulo César Farias, o PC.

O desenrolar dos acontecimentos e denúncias de uma Comissão Parlamentar de Inquérito - CPI e o papel dos veículos de comunicação em levá-los à tona, segundo Waisbord (2000), estimulou e favoreceu a dedicação da imprensa brasileira para investigar escândalos de corrupção - isso aconteceu também em outros países da América Latina que saíram de regimes autoritários - categorizando os jornalistas como cães de guarda (watchdogs), fiscalizadores da política e guardiões da ética, como mencionamos na Introdução. Thompson (2002) completa que outra função do jornalista que cobre escândalos é mostrar as transgressões éticas da política que até então eram mantidas em 
segredo, sem o conhecimento do público. A teoria de Thompson (2002) sobre o tema e seus desdobramentos serão detalhados mais adiante.

Aldé aponta (2004) que, no Brasil, a Constituição de 1988 e o modelo democrático do país pós-Ditadura não contribuíram apenas para fortalecer a ideia de uma imprensa livre e comprometida com o interesse público. Ela lembra que no conjunto de mudanças na forma de noticiar a política, explicadas acima, entra o interesse mercadológico dos veículos de comunicação, que precisam tornar seus conteúdos atraentes para o público-consumidor. A dramatização da política, principalmente em relação à cobertura dos escândalos, é um desses instrumentos, tema que será aprofundado no capítulo teórico-metodológico.

Lima (2004) formulou o conceito de Cenários de Representação da Política na mídia e discorre inicialmente sobre a relação hegemônica entre os grandes veículos de comunicação e seus destinatários. O autor cita o pensamento de Antonio Gramsci de que a hegemonia, no sentido da teoria política, se dá a partir articulação de um bloco histórico dominante, que tem como base material a sociedade civil, para se manter no poder ou usar de coerção com quem tenta enfrentá-lo. “[A hegemonia] é um senso de realidade para a maioria das pessoas na sociedade, um senso de realidade absoluta (...) tem que ser continuamente renovada, recriada, defendida e modificada" (p.12). Segundo ele, a hegemonia também é desafiada e sofre pressões.

Muito além da definição de hegemonia como se fosse uma simples dominação de país sobre o outro, ou do que é considerado mais forte sobre o mais fraco, Lima (2004) aponta que se trata de um processo cultural que envolve práticas, expectativas, significados, valores e se constitui em cenários e espaços próprios. A hegemonia, na visão do autor, compõe o conjunto das representações, entre elas, as que são reforçadas pelas ideias predominantes (enquadramento) da mídia.

Ele exemplifica que, nas democracias contemporâneas, os cenários de representação na política são construídos por contrastes como direita e esquerda ou conservador e progressista. "O espaço específico das diferentes representações da realidade, lugar e objeto da articulação hegemônica total, construído em processos de longo prazo na mídia e pela mídia" (p.14). 
De acordo com o autor, as pesquisas em comunicação se utilizam do reconhecimento de que, numa sociedade de classes, existe desigualdade, domínio e subordinação nos processos sociais. "Porque sempre haverá necessariamente sempre um CR hegemônico, dominante e CR contra-hegemônicos, subordinados, alternativos" (LIMA, 2004, p.15).

Lima (2004) justifica que os veículos de comunicação têm o papel de produtores privilegiados da esfera pública na construção do cenário político, que expressa os interesses do bloco histórico dominante. "Um candidato em eleições nacionais e majoritárias, dificilmente vencerá as eleições se não ajustar sua imagem pública ao CR-P dominante" (p.31).

Nesse contexto, a mídia hegemônica se coloca como responsável por narrar fatos reais notíciáveis e de interesse público (que causem impacto no cotidiano, envolva muitas pessoas, escândalos políticos, tragédias, que sejam memoráveis para a audiência). Esse posicionamento é convergente ao que dizem os teóricos dos Estudos Culturais: existe uma realidade e também fatores externos que a representem. Lima (2004) destaca que a mídia é um desses fatores. As representações que a mídia faz da realidade passam a constituir a própria realidade.

Citando Wolf (1987), Lima (2004) aponta que a cobertura midiática dos fatos noticíaveis utiliza valores pré-estabelecidos, está inserida em um conjunto de práticas textuais que exigem dos destinatários das mensagens uma competência interpretativa. A estratégia da mídia diante disso é articulá-la por meio de textos já consumidos. "Ou seja, em referência aos textos precedentes e ao confronto intertextual. Essa cultura da mídia é a expressão do hegemônico" (LIMA, 2004, p.17).

Sobre isso, Lima (2000) afirma que a preferência editorial pelo denuncismo, termo também utilizado por Waisbord (2000), ao invés de noticiar na mesma medida os aspectos positivos das instituições públicas ou problemas reais do país, entre eles, o racismo e a desigualdade social, as representações políticas estão se tornando cada vez mais desacreditadas pela população por influência da mídia porque a política é tratada de forma hegemônica - o que pode levar o público a fazer associação direta da figura de todos os políticos com a corrupção - e espetacularizada. 
Portanto, para Lima (2000), o conflito entre personagens, que podem ser protagonistas ou antagonistas segundo a cobertura caracteriza a narrativa política. $\mathrm{O}$ próprio modelo democrático contemporâneo, dos políticos serem eleitos de forma individual e os governos não serem do povo e sim autorizados, como argumenta Aldé (2004), favorece esse comportamento padrão no fazer jornalístico brasileiro. "É a mutação do governo representativo, equivalente a revolução promovida pelo sufrágio universal e pelos partidos" (p.21). Seguindo os preceitos de Bernard Manin, Aldé (2004) reitera que o distanciamento ideológico, advindo da ausência de mediação dos partidos, que também tratamos no item acima, de fato, provoca o declínio "nas relações de identificação entre representantes e representados" (p.20).

Segundo Aldé (2004) o voto é um dos poucos instrumentos de participação popular, que transfere autoridade para um representante. O papel da mídia se tornou ainda mais central, porque é por meio dela que o eleitor se informa sobre os seus candidatos e pode até decidir seu voto. "é requisito que a opinião pública sobre os assuntos políticos seja livre e plural e que o cidadão comum tenha acesso suficiente à informação sobre política e decisões governamentais" (Aldé, 2004, p.21). Dentro desse contexto, as personalidades políticas se profissionalizam para serem midiáticas, para discursar em transmissões ao vivo, responder perguntas e também ser fonte para os repórteres.

Ao descrever o modelo de eleições nos Estados Unidos e a influência da mídia durante o período, McCombs (2009) reitera que nos momentos cívicos, os cidadãos precisam de orientação, principalmente em função do número de candidatos. Nos casos de eleições primárias, a filiação partidária também fica obsoleta porque os candidatos pertencem aos mesmos partidos. "Em todas as circunstâncias, os eleitores frequentemente buscam os mass media, seja para acumular notícias sobre a situação vigente ou endosso editorial dos jornais. Nem todo eleitor sente essa necessidade de orientação naturalmente" (p.90).

Da mesma forma como foi destacado acima por Martins (2005) e Lima (2000), Aldé (2004) concorda que a declaração de neutralidade política, ideológica e partidária dos veículos de comunicação é relevante para o modelo democrático contemporâneo. "Nesse tipo de sociedade, é possível observar um sistema jornalístico caracterizado pela homogeneização da informação política” (p.24). 
Matos (2008) acredita que esses valores foram importantes para dar seriedade à profissão do jornalista e credibilidade aos veículos de comunicação, "apesar das alegações de objetividade serem problemáticas no Brasil, um país mergulhado em instituições altamente politizadas" (p.71). Ela também considera que o jornalismo brasileiro tem que lidar com restrições políticas e econômicas "que incluem a maximização da concentração da mídia e o rebaixamento de certos padrões de qualidade para atingir públicos maiores" (p.281).

Para Guazina (2014), a credibilidade assegura ao jornalismo um lugar de poder na sociedade, quando os veículos de comunicação, por meio dos repórteres e da cobertura política, assumem a posição de porta-vozes do interesse público mesmo sem terem sido eleitos pelos cidadãos.

Já a separação entre o setor comercial e editorial se desenvolveu nos maiores veículos de comunicação para garantir a credibilidade e assim conquistar público/audiência e, consequentemente, anunciantes e receita, na visão de Bucci (2000). Diante da crise pela qual enfrenta os jornais impressos, principalmente após o advento da internet, as duas últimas décadas foram marcadas por demissões e enxugamento das redações e isso tem afetado profundamente a cobertura política, segundo Guazina (2011) e Miguel (2010): a busca pelo furo, a competição entre os jornalistas concorrentes, que leva a divulgação dos escândalos que, ao longo do tempo, no atual modelo democrático brasileiro, contribuiu para o declínio da confiança na política.

Apesar do entendimento que existe separação entre os setores comercial e editorial, por exemplo, Guazina (2011) destaca que irregularidades envolvendo empresas privadas não têm o mesmo destaque na mídia do que os escândalos e nem a mesma fiscalização. Ela considera que o princípio da desconfiança da política e dos políticos, com ênfase nos escândalos políticos, é um dos norteadores da prática profissional e do ethos jornalístico.

Segundo Miguel (2010), mesmo no século XXI, ainda vigora o senso comum de que os políticos não são confiáveis, gostam de mordomias e se utilizam da corrupção para conquistar seus objetivos. "Essa percepção está presente em países ricos e pobres em velhas e novas democracias" (p.223). Acrescenta que vários indicadores apontam para o declínio da confiança na política em ambientes democráticos no Ocidente, que conciliam 
valores como a soberania popular com "a falta de fé nos mecanismos institucionais" (p.223).

A alta expectativa depositada pela população em relação aos governos, por exemplo, ajuda a construir esse cenário para Miguel (2010). O pesquisador enumera outras explicações para esse fenômeno. Um deles se concentra na percepção dos cidadãos de que os políticos atuais não são tão bons quantos os do passado. Um dos exemplos é o fracasso no atendimento das demandas da sociedade civil que se mobilizou por direitos nos anos 1960: pacifismo (principalmente contra a Guerra do Vietnã), movimento negro e a ofensiva feminina. "Os governos democráticos, reféns do voto popular, tentavam atender sem possuir recursos para tanto" (p.225).

Desde então, a visão sobre a inutilidade da política começou a se consolidar entre os cidadãos que reduziram suas mobilizações por considerarem que não seriam atendidos; o envolvimento de políticos em escândalos de corrupção; a erosão das lealdades partidárias; o fracasso das alternativas socialistas e a influência midiática, principalmente da televisão. "Se os políticos se tornaram cínicos, isso se deu em reação ao cinismo no público. O elemento central, porém, seria a mídia, responsável por difundir uma imagem negativa dos agentes da esfera pública" (p.226).

Miguel (2010) argumenta, com base nos estudos de Capella e Jamieson (1997), que haveria um círculo vicioso envolvendo a cobertura midiática sobre política, as expectativas do público e comportamento dos políticos. Diante disso, os políticos sentem que não adiantaria assumir uma postura correta e voltada para o bem comum "pois sempre serão encarados como auto interessados e carreiristas. Os jornalistas saberiam que seus leitores esperam uma leitura neste diapasão" (p.227).

Sobre o jornalismo político especificamente, Miguel (2010) ressalta que os repórteres aprendem a especular quais os interesses e vantagens por trás da realização de políticas públicas, por exemplo, ao invés de explicar ou avaliar quais seriam seus efeitos positivos na população. "Nosso governo nos parece pior porque não faz o que os outros governos fazem e que os meios de comunicação não mostram" (p. 232).

Na visão do Miguel (2010), é um tipo de narrativa onde predomina a negatividade e a exigência por respostas rápidas, que prejudicam a qualidade das decisões políticas. Esse 
aspecto também é destacado por Waisbord (2000) quando trata da cobertura política no Brasil.

Segundo Guazina (2014), os estudos de Moisés (2008) indicam que o Brasil ocupa o primeiro lugar em relação aos baixos índices de identificação partidária. A avaliação negativa do Congresso Nacional também vigora entre esses itens, levando em consideração que "as experiências que a maioria dos cidadãos tem em relação aos poderes e em casos de denúncias de corrupção passam, necessariamente, pela mediação dos meios de comunicação" (Guazina, 2014, p.4).

No caso do Brasil, várias pesquisas com o objetivo de medir a confiabilidade da população em diferentes instituições apontam a prevalência da desconfiança da política.

Em uma das pesquisas mais recentes, citada por Guazina (2014), realizada pelo IBOPE Inteligência, em 2013, a imprensa está entre as cinco instituições consideradas mais confiáveis pela população e perde para o Corpo de Bombeiros, Igrejas e Forças Armadas.

Segundo levantamento, realizado pela Ordem dos Advogados do Brasil (OAB) em $2003^{1}$, 34\% dos brasileiros revelaram ter confiança no Poder Legislativo. Foi a instituição pública com pior avaliação, seguida pelo Poder Executivo, com 58\% e Judiciário com 37\%. $\mathrm{Na}$ mesma pesquisa, imprensa e a Igreja tiveram índices elevados de credibilidade, $60 \%$ e $74 \%$, respectivamente.

Em 2010, outra pesquisa, dessa vez realizada pelo Instituto Sensus, encomendada pela Confederação Nacional dos Transportes (CNT), constatou que 45\% dos eleitores não têm confiança no Congresso Nacional ${ }^{2}$. A imprensa aparece com 16,7\% da confiança e as Forças Armadas com 9\%. Foram as instituições que apresentaram os maiores índices. A pesquisa foi realizada entre os dias 25 e 29 de janeiro de 2010, em 136 municípios de 24 estados brasileiros. Duas mil pessoas foram consultadas. A margem de erro é de três pontos percentuais, para mais ou menos.

1

Disponível em Freitas:2008,p.19

${ }^{2}$ Disponível em http//:www1.folha.uol.com.br/folha/.../ult96u687573.shtml - acesso em 09 de maio de 2010. 
Os dados mais recentes do Consórcio Latinobarômetro sobre a relação do Brasil com o sistema democrático e confiança nas instituições são de 2013. A somatória de percentuais daqueles que responderam não muito satisfeito e não satisfeito com regime democrático no país é de 69,2\%. Porém, 48,5\% concordam que a democracia é preferível a qualquer outra forma de governo.

O Consórcio também mapeou os níveis de confiança dos entrevistados em várias instituições governamentais e não governamentais, inclusive os meios de comunicação jornal impresso, rádio e televisão. Para este trabalho, fizemos o recorte de comparação da somatória daqueles que responderam pouco confiar e não confiar em instituições públicas com os que responderam ter muita e alguma confiança nos veículos de comunicação.

No Quadro 1, observamos os dados do Latinobarômetro relativos à pouca e nenhuma confiança em instituições públicas no Brasil.

\section{Quadro 1}

\begin{tabular}{|l|l|}
\hline Congresso Nacional & $76,10 \%$ \\
\hline Administração Pública & $63,70 \%$ \\
\hline Governo & $58,80 \%$ \\
\hline Poder Judiciário & $54,80 \%$ \\
\hline Estado & $51,60 \%$ \\
\hline Forças Armadas & $30,30 \%$ \\
\hline
\end{tabular}

Fonte: Latinobarômetro/2013

\section{Quadro 2}

No Quadro 2, reunimos os dados relativos a muita e alguma confiança nos meios de comunicação de massa. 


\begin{tabular}{|l|l|}
\hline Jornal & $56,50 \%$ \\
\hline Rádio & $53,00 \%$ \\
\hline Televisão & $52,80 \%$ \\
\hline
\end{tabular}

Fonte: Latinobarômetro/2013

Ou seja, de 2003 a 2013, podemos concluir que os índices de descrédito na política se mantiveram em patamares altos, enquanto que os de confiança na mídia também, o que ajuda a compreender a importância da cobertura jornalística para dar visibilidade aos fatos que levam a desconfiança na política e nos políticos.

A seguir, vamos tratar especificamente dos escândalos políticos midiáticos, como eles se desenvolvem, suas causas, consequências e implicações na reputação dos políticos. 


\section{CAPÍTULO II}

\section{ESCÂNDALO POLÍTICO: CAUSAS, CONSEQÜÊNCIAS, REPUTAÇÃO E NARRATIVA}

\section{1 - O escândalo-político segundo Thompson}

No capítulo anterior, falamos sobre como as mudanças trazidas pela profissionalização do jornalismo influenciaram na busca pelo ideal de objetividade, imparcialidade e isenção das notícias. Nas sociedades democráticas modernas, é o caso do Brasil, a mídia passou a ocupar um papel de destaque na cobrança por honestidade e ética na política, principalmente por meio da divulgação de fatos que, ao longo da cobertura, se constituem em escândalos políticos.

O escândalo midiático, como tratado no capítulo 1, é um dos fatores que promovem a desconfiança da política e dos políticos, como afirma Guazina (2011). É onde vamos nos concentrar agora, levando em consideração, a partir dos estudos de Thompson (2002), que o Mensalão e as funções atribuídas a José Dirceu nas matérias da revista Veja sobre o caso, que serão analisadas na presente pesquisa, se enquadram nas definições, características e categorias de escândalos político-midiático enumeradas pelo autor.

De acordo com Thompson (2002), a cadeia produtiva dos escândalos se intensificou com a formação dos estados nação que proporcionaram mudanças políticas e econômicas após a Idade Média na Europa. Isso favoreceu o surgimento e os avanços tecnológicos da imprensa. O desenvolvimento dos meios de comunicação em cada país iniciou um processo de distinção entre o público e o privado a partir da consolidação dos poderes políticos.

Os meios de comunicação deram visibilidade aos fatos do dia a dia relacionados à política e aos políticos que antes eram inacessíveis ao grande público, diz Thompson (2002). O rádio contribuiu ainda mais para isso, levando em conta a ligação histórica do meio com a atuação dos líderes de regimes autoritários - fascistas e nazista - que precisavam se comunicar com milhões de pessoas para convencê-las a aderir às suas 
filosofias e convicções. No Brasil, esses recursos foram utilizados por Getúlio Vargas quando presidente da República de 1930 a $1945^{3}$.

A televisão e os meios eletrônicos ampliaram esse alcance, fazendo até com que o cidadão se sinta mais próximo dos políticos, como afirma Tavares (2014), por meio da interação nas redes sociais a exemplo do Facebook e do Twitter. Thompson (2002) também considera que a imagem gerada pela TV ou por outras mídias (podemos citar o canal de vídeos YouTube), parece tornar os políticos mais íntimos da audiência, porém, também os deixam mais vulneráveis aos escândalos.

Para se explicar os escândalos políticos, Thompson (2002) apresenta um histórico das definições sobre eles mais utilizadas, inclusive do sentido lingüístico. No século XVI, o termo era usado inicialmente no aspecto religioso, tratava de quem se desviava das crenças, ou as colocava em dúvida. Depois evoluiu para situações mais gerais relacionadas a "transgressões de códigos morais" (p.39). Nos dias atuais, segundo Thompson (2002), a definição de escândalo inclui o fato de certos tipos de transgressões serem realizados em sigilo e se tornarem públicos "e que são suficientemente sérios para provocar uma resposta rápida" (p.40). Dessa forma, entra o papel da mídia que possui instrumentos técnicos e de investigação para que os desvios éticos venham à tona.

Thompson (2002) detalha também as características dos escândalos políticos e ainda os divide em categorias, tais como: os escândalos sexuais (que afetam celebridades do mundo artístico e também personalidades da política); os escândalos financeiros; e os escândalos de poder (um dos exemplos é o caso Watergate que provocou o impeachment, nos anos 1970, do então presidente dos Estados Unidos Richard Nixon).

Segundo o autor, nos regimes democráticos liberais, escândalos são mais frequentes porque a imprensa é livre e não tem mais vinculação formal com partidos políticos, fatores que tratamos nos itens anteriores. O poder do voto confere à população a confiança de que seus líderes políticos vão atuar em favor do bem comum. Mas, ao mesmo tempo, essa relação pode seguir caminho oposto. "Cidadão comuns se tornaram propensos a acreditar que muitos políticos profissionais seriam tentados a colocar seus próprios interesses acima dos do povo que supostamente eles representam" (Thompson, 2002, p.305).

${ }^{3}$ Cf. Martins e Luca (2008). 
De acordo com Thompson (2002), as democracias liberais se configuram em um período de incertezas sobre como lidar com os problemas do mundo moderno. "Onde temos de colocar sempre mais fé em nossos líderes políticos para que tomem decisões sensatas e projetem nossos interesses" (p.147). Manifesta-se então o desejo popular pela garantia de que promessas serão cumpridas e de que os políticos sigam códigos morais.

Thompson (2002) reitera que, em alguns casos, existe mais preocupação com a honestidade ou com a vida privada do político do que com a sua capacidade técnica: "podem ser fonte de profundo desapontamento e assombro, pois, podemos perceber que indivíduos não correspondem às expectativas que deles tínhamos” (p.119).

Portanto, o sistema político molda, ao longo do tempo, os critérios de confiança dos cidadãos. Diz Thompson (2002) que, por meio da confiança, lidamos com a incerteza ou risco das ações e decisões que dependem dos outros. Implica a quem confia, pressupor a possibilidade do desapontamento. "A confiança, como a reputação é um recurso que não se consome com o uso. Pelo contrário, quanto mais ela é usada, maior será o estoque de confiança" (p.303).

Políticos fazem uso de seu estoque de confiança em articulações por alianças ou parcerias futuras. O próprio escândalo do Mensalão está relacionado com as alianças partidárias e acordos de campanha, como afirma Leite (2013). No Brasil, a base aliada dos governos começa a ser a formada desde a campanha eleitoral por meio das coligações e isso precisa envolver algum tipo de confiança de que acordos serão cumpridos.

Em relação aos cidadãos, Thompson (2002) afirma que as democracias liberais são marcadas pelo gradual declínio da política ideológica e a crescente importância da política de confiança. "Cada vez mais os partidos e seus líderes têm que lutar para ganhar apoio de uma crescente parcela de eleitores não comprometidos" (p.146).

Continua Thompson (2002) que "nenhum indivíduo, incluindo o proeminente detentor do poder, está acima da lei. Por conseguinte, alegações referentes a transgressões podem ser feitas mais facilmente por indivíduos e organizações da mídia” (p.129)

O autor (idem) justifica o declínio na confiança da política nos regimes democráticos contemporâneos - tema tratado no capítulo 1 - em função da burocracia que 
dificulta o desenvolvimento e a eficiência do serviço público. Para ele, a criação de órgãos fiscalizadores, que investigam casos de corrupção, é importante, mas é a transparência nas ações do poder público e dos políticos em geral que reduz o sigilo e as justificativas para a ocorrência de escândalos. "Uma maior abertura e prestação de contas em nossos sistemas de governo são uma característica desejável para uma ordem democrática e um meio essencial para combater abusos de poder" (p.320).

No caso do Brasil, os jornalistas e os órgãos fiscalizadores como o Ministério Público Federal, a Polícia Federal ou até mesmo as Comissões Parlamentares de Inquérito - CPIs podem ser considerados, a partir da ótica do Thompson (2002) como não participantes do escândalo por revelarem o que os participantes gostariam de esconder. "Se não houver não-participantes suficientemente interessados em, ou preocupados com a transgressão para expressarem sua inquietação aos outros, então o escândalo não aparecerá" (p.47)

O escândalo político-midiático é, na visão de Thompson (2002), uma característica endêmica da cultura política contemporânea. "Graças à mídia, alguns escândalos se tornaram parte das memórias coletivas em sociedades muito afastadas daquelas em que eles estiveram inicialmente situados" (p.151). De acordo com o autor, a cultura política reúne regras, convenções, atitudes e expectativas, além de moldar os processos comunicativos no campo político. "O próprio fato de ele (escândalo) surgir é condicionado pelo conjunto específico de convenções e expectativas que definem essa forma cultural" (p.152).

Podemos então afirmar, baseado em Thompson (2002), que o Mensalão é um escândalo político por envolver indivíduos ou ações que estão situados dentro de um campo político. "É um campo de ação e interação que tem a ver com a aquisição e o exercício do poder político" (Thompson, 2002, p.130). E, como sabemos, um dos objetivos pretendidos pelo campo político é o exercício do poder simbólico definido por Bourdieu (1998). "Os representantes devem usar o poder simbólico para persuadir e confrontar, para influenciar ações e crenças, cultivar relações de confiança e influenciar, o mais que puderem, o curso dos acontecimentos" (Thompson, 2002, p. 134). 
O Mensalão e outros escândalos na área são exemplos de que o campo político está se tornando cada vez mais um campo midiático. "Cidadãos estão sendo moldados pelas formas midiáticas de comunicação" (Thompson, 2002, p.142).

Uma das constatações de Guazina (2011) é que as disputas, tensões e conflitos entre o campo jornalístico e o campo político se acentuam durante os escândalos, no que ela chama de cobertura adversária. De um lado, os jornalistas "fiscalizadores do poder" e defensores do interesse público, de outro, o político afetado pelo escândalo que quer se fazer acreditar, mas precisa da mídia para isso. Ou seja, há também similaridades entre os dois campos, entre elas, a busca pela credibilidade.

“Aqueles que querem usar o escândalo como arma política irão provavelmente encontrar algum fórum midiático onde as revelações e alegações podem ser apresentadas à arena pública" (autor, p.111). Também participam desta arena aqueles políticos que, com estoque de confiança e reputação, questionam os desvios éticos dos colegas e se tornam referências para a mídia em situações de crise política. No Congresso Brasileiro, podemos citar três exemplos, os senadores Cristovam Buarque (PDT/DF), Eduardo Suplicy (PT/SP) e Pedro Simon (PMDB/RS).

Como já foi explicado no capítulo 1, após a modernização dos meios de comunicação, especialmente nos veículos impressos, a desvinculação dos jornais dos partidos políticos começou a vigorar junto com o ideal de imparcialidade e objetividade. Daí surgiu o jornalismo investigativo, que Correia (2012) define como "anatomia do escândalo político" (p.121). Porém, ele explica que, nos últimos anos, na maior parte dos casos, a imprensa não realiza investigações por conta própria e sim depende de órgãos fiscalizadores para publicar suas matérias reveladoras. "O jornalismo investigativo movese em um campo minado por interesses diversos e é mais dependente dos vazamentos de informação" (p.128).

Waisbord (2000) completa que mesmo na posição de cão de guarda (watchdog) e fiscalizador do poder, o jornalista bem-sucedido é aquele próximo das fontes oficiais, condição que pode gerar coberturas sobre problemas no governo, outras instituições ou órgãos. 
Nos Estados Unidos, o jornalismo investigativo ganhou mais espaço na cobertura política após o caso Watergate, na década de 1970. Segundo Thompson (2002), o escândalo político midiático implica na "revelação, através da mídia de atividades previamente ocultadas e moralmente vergonhosas" (p.82) e isso já acontece desde o século XIX. "Há certamente uma estreita afinidade entre escândalo e mídia que foi explorada pelos provedores da palavra impressa desde a era dos panfletos e dos libelos: escândalo vende" (p.59).

Em paralelo à emergência dos escândalos político-midiáticos, formou-se na comunidade profissional o ethos jornalístico, também mencionado no capítulo 1, quando os jornalistas começaram a entender sua importância em descobrir e apresentar os fatos, criar debate público e influenciar no processo político. "A revelação de segredos ocultos do poder é vista por alguns jornalistas como uma forma de exercer sua missão de guardiões do interesse público" (Thompson, 2002, p.60).

A partir das mudanças no cenário político contemporâneo e mais especificamente, Thompson (2020) aponta que a prevalência dos escândalos ocorre em função da visibilidade dos líderes políticos; avanços nas tecnologias da comunicação e na vigilância (com instrumentos cada vez mais sofisticados e acessíveis, que podem gerar evidências por meio de fotografias ou gravações); a internet, cujo ambiente torna mais difícil para o político manter um segredo, os órgãos de regulamentação e fiscalização da vida política e dos governos, a mudança na cultura jornalística, mudança na cultura política e fragmentação da vida pública, caracterizada pela diferenciação do que é interesse público ou invasão de privacidade.

O Estado Constitucional deu lugar a um Estado clandestino, invisível, composto
por lobbies que desvirtuam a vida pública. Com esta proclamação, não
pretendemos asseverar que todos os homens públicos se deixam corromper,
embora seja evidente a propensão do político para quebrar princípios éticos.
(PRIOR AT AL, 2015, p.5)

Os políticos passam a enfrentar as consequências da visibilidade midiática, entre elas, a vulnerabilidade aos escândalos. "Embora alguém queira gerenciar a auto apresentação através da mídia não se poderá controlá-la completamente” (Thompson, 2002, p.143). 
Thompson (2002) enumera assim as principais características do escândalo político-midiático:

- Sempre duram mais que um dia, pois isso depende de como os outros vão responder as revelações e alegações iniciais;

- Começa com um ato de revelação; além da imprensa, o objeto do escândalo é questionado por outras instituições públicas e jurídicas;

- O ponto final do escândalo quase sempre é uma confissão ou renúncia e o escândalo gera interesse da audiência pela intensa cobertura do desenrolar dos fatos e porque a conclusão é incerta.

Já as orientações para a criação de escândalos pela mídia são, na visão do autor, o lucro financeiro, objetivos políticos, auto concepções profissionais e rivalidades competitivas. "Em alguns casos, e especialmente em casos de escândalos políticos, poderá haver indivíduos particulares e grupos de interesse que estarão procurando usar o escândalo como meio de desacreditar em seus opositores" (Thompson, p.108).

O autor lembra também que os escândalos predominam nos jornais populares, mas os escândalos políticos, dependendo de sua relevância no cenário local, aparece com grande frequência nos grandes jornais. "A imprensa de qualidade desempenhou também papel importante na criação de escândalos midiáticos” (Thompson, 2002, p.295).

As pressões mercadológicas exercidas pelas empresas de comunicação para conquistar audiência - que o se tornou ainda mais necessário para a sobrevivência em relação aos concorrentes - também favoreceu a divulgação dos escândalos, incluindo não só os políticos, mas os que envolvem celebridades, evidenciando a mistura de fatos públicos e privados na cobertura jornalística.

Holanda (1995) explica que no Brasil, por exemplo, a confusão entre público e privado teve origens na dificuldade de distinção entre família e Estado, que iniciaram no século XIX, quando prevaleciam as vontades particularistas e provincianas. Porém, segundo ele, "só pela transgressão da ordem doméstica e familiar é que nasce o Estado e que o simples indivíduo se faz cidadão, contribuinte, eleitor, elegível, recrutável e responsável ante as leis da Cidade" (p.141). 
Os políticos em geral, pela visibilidade que possuem, acabam sendo obrigados a dar satisfação de sua vida pessoal, principalmente, e conforme a constatação de Holanda (1995), de suas relações familiares. É muito comum um candidato levar a esposa para seus comícios ou usar depoimentos dos filhos em campanhas eleitorais para mostrar que, como se trata de um bom pai, será um bom governante.

A figura da primeira-dama ainda é muito referenciada. A esposa do presidente da República acaba se tornando uma celebridade (com destaque para suas roupas, decoração da casa e estilo) e a falta dela também fragiliza, de alguma forma, o governante. Um dos exemplos é o ex-presidente Itamar Franco. Ele não era casado, então, a curiosidade da mídia de celebridades girava em torno de quem seria sua então namorada, June Drummond, que trabalhava no Itamaraty. Ela foi capa de várias revistas entre 1993 e 1994, mesmo sendo esse um período de crises e mudanças na economia brasileira. Se levarmos em consideração o que diz Holanda (1995) a vida pessoal do eleito não deve influenciar a visão sobre o seu papel perante o Estado que precisa ser cumprido, independentemente de suas decisões fora do âmbito público.

Quando se trata de José Dirceu, após a análise das edições apresentadas na presente pesquisa, Veja leva em consideração sua vida pessoal para justificar ações políticas, inclusive, no escândalo do Mensalão. A fama de bonitão e mulherengo construída desde a década de 60, como será detalhado mais adiante, se manteve ao longo dos anos, mesmo quando Dirceu mantinha relações afetivas consideradas estáveis.

A própria linguagem narrativa dos escândalos políticos, como mostra Prior at al (2015) gera uma estrutura de acontecimentos que se utiliza de elementos dramáticos, como a relação e o conflito entre os personagens da ação, que acabam promovendo a confusão entre público e privado.

Esse conflito ou a controvérsia figuram entre os valores-notícias propostos por Traquina (1993) como disputa simbólica entre líderes políticos. Já o valor-notícia da infração, supostamente cometida por políticos, principalmente, alimenta os escândalos midiáticos. Assim, a divulgação de escândalos compõe a rotina jornalística e os modos de produção: como a preferência por manchetes novas, atualizadas, chamativas e tendenciosas 
que podem ter a capacidade de transformar as notícias sobre política em entretenimento, por exemplo.

Gomes (2007) discorre sobre a analogia entre a novidade política e o espetáculo. Ele lista as características do espetacular: "o notável, admirável, o apreciável, o que não pode deixar de ser visto" (p.393). O autor considera que a exibição política que chega ao cidadão pelos veículos midiáticos o coloca na posição de espectador e consumidor de um produto do show business. "A política contemporânea seria espetacular porque se dedica à tarefa de providenciar eventos, fatos e situações e textos que se impõem na esfera de visibilidade da comunicação de massa" (p.394).

Porém, Thompson (2002) enfatiza que nem sempre o critério para a criação e divulgação de escândalos político-midiáticos é exclusivamente o lucro da empresa por parte de jornalistas e editores, quando isso acontece trata-se de exceções. "A importância do interesse no lucro econômico tem menos a ver com as motivações do pessoal da mídia do que com a estrutura geral das organizações da mídia" (p.109). O autor avisa que o escândalo se consolidou como gênero marcante no jornalismo e a estrutura das empresas contribui para isso.

Na comunidade jornalística, como aponta Traquina (1993), o escândalo é um dos motivos que favorece a busca pelo "furo": "uma conquista que está associada ao brilho profissional, razão justificada de vaidade pessoal e que fornece prestígio" (Traquina, 1993, p.55). Waisbord (2000) completa que as coberturas que envolvem a descoberta de atos de corrupção na política dão mais prestígio ao jornalista do que a denúncia de injustiças sociais. Segundo ele, para alguns profissionais, é mais fácil apurar e escrever sobre problemas evidentes do que sobre as entranhas do poder, que quase sempre são inacessíveis caso não haja investigações.

Portanto, a suspeita e a desconfiança nas democracias liberais podem contribuir para criar instrumentos de fiscalização regular sobre a atuação dos políticos, mas a imprensa se posiciona como um deles mesmo não tendo sido designados pelo poder público para atuar dessa forma. "O sigilo tende a aumentar escândalos que, por sua vez, tendem a aumentar a sensação de suspeita: em uma cultura marcada pelo escândalo, a 
impossibilidade de perscrutar as ações que são exercidas produz desconfiança" (Thompson, 2002, p.320)

Essa desconfiança pode se tornar profunda após uma sequência de escândalos. Aí está o risco na burocratização desses processos, o que pode fortalecer a ideia de ineficiência e a preocupação na opinião pública. Inclui-se nesse contexto, a preferência, como já foi dito, inclusive midiática, da ética em relação à qualificação profissional e técnica do político. Há mais julgamento de caráter. "Isso pode levar a um afastamento do processo político, que pode ser expresso pela falta de interesse em votar" (Thompson, 2002, p.307).

Mesmo os políticos comprovadamente competentes como gestores não estão imunes à perda da confiança trazida por um escândalo. "É difícil evitar a conclusão de que a cultura política do escândalo provavelmente não poderá contribuir para tornar mais fácil a construção de uma forma de democracia mais forte e mais participativa” (idem, p.311).

\section{2 - A reputação do político envolvido em escândalos}

Uma das principais características gerais dos escândalos, trazidas por Thompson (2002), que pode ser aplicada ao escândalo do Mensalão e a situação vivenciada por José Dirceu ao longo da cobertura jornalística sobre o caso, em especial, na revista Veja, é a de que "a revelação e condenação das ações e acontecimentos podem prejudicar a reputação dos indivíduos responsáveis por eles" (p.40). O autor explica que, ao longo de suas carreiras, alguns políticos acumulam capital simbólico dentro dos aspectos da ética e da honestidade e levam tempo para conquistar esse patamar. O envolvimento em um escândalo de corrupção pode destruir o poder, o capital simbólico e a reputação rapidamente.

Traquina (1993) completa que o político corrupto é o maior inimigo da comunidade jornalística pois se torna alvo dos jornalistas com o perfil de fiscalizadores do poder (cães de guarda ou watchdog), que se enxergam como defensores da ética na política e do interesse público. "Todos exercemos poder simbólico em nossas vidas para influenciar os outros e para confrontar o curso dos acontecimentos. A reputação é um desses recursos a fim de conseguir nossos interesses e objetivos" (Thompson, 2002, p.51). 
O caso do Brasil, no que diz respeito a escândalos políticos e sua divulgação na mídia após a redemocratização, pode ser associado à "sensibilidade ao Escândalo", termo usado por Thompson (2002) para definir o grau de influência das normas e valores de acordo com os valores culturais proeminentes em cada lugar onde o escândalo acontece. Os regimes democráticos são mais sensíveis aos escândalos por possuírem dispositivos legais que devem ser cumpridos por todos os cidadãos de forma igualitária. As transgressões de normas e valores podem frequentemente levar ao escândalo, principalmente quando "envolvem séria desonestidade ou corrupção" (Thompson, 2002, p. 42).

Podemos dizer então, baseado no que foi tratado no capítulo 1, que no Brasil possuímos uma espécie de "sensibilidade ao Escândalo" porque se instalou no país um clima de desconfiança na política e nos políticos em função da preferência dos veículos de comunicação pela investigação e cobertura dos escândalos em relação a outros assuntos, inclusive positivos, que envolvem os Poderes. "Os políticos poderão ter surpresas quando, em contextos onde há alto grau de sensibilidade à corrupção, até mesmo deslizes relativamente pequenos podem se tornar motivo de renúncia” (idem, p.58).

Além do escândalo do Mensalão, que será detalhado no capítulo sobre contextualização histórica, podemos citar outros casos que afetaram a atuação política dos envolvidos no Brasil. O senador Jader Barbalho (PMDB/PA) renunciou ao mandato após acusações sobre desvios de recursos públicos da Superintendência de Desenvolvimento da Amazônia - Sudam em 2001. Os senadores Antonio Carlos Magalhães e José Roberto Arruda também renunciaram ao cargo por envolvimento na quebra do sigilo do painel eletrônico do Senado referente à sessão que decidiu pela cassação de Luiz Estevão em 2000. O caso mais recente envolveu o senador Demóstenes Torres (DEM/GO), em 2012, que foi cassado após a divulgação de escutas telefônicas que trouxeram à tona supostas relações de troca de favores com o contraventor Carlinhos Cachoeira.

Outro ponto considerado pelo autor justifica a nossa análise sobre o impacto causado pelo escândalo do Mensalão. O PT, partido que José Dirceu ajudou a criar em 1980, manteve uma linha política de oposição aos governos após a redemocratização e também de defesa da ética e honestidade na política, como afirma Leal (2005). Por essas razões, estaria mais comprometido com valores morais relacionados ao combate à 
corrupção. Como ressalta Thompson (2002): "Muitos escândalos envolvem o elemento de hipocrisia, não apenas a transgressão de normas, mas a transgressão de normas por pessoas cuja prática não corresponde ao que elas pregam para si mesmas” (p.42).

O autor (2002) aponta ainda que nem todos os escândalos estão intimamente ligados com os interesses da população, assim como grande parte das pessoas pode não dar a atenção requerida pela mídia para o caso. "A construção de um escândalo está muitas vezes associada a um processo amplo de moralização pelos que denunciam a ação como escandalosa" (p.43).

Na visão de Thompson (2002) há casos de corrupção, por exemplo, que ofendem e chocam a sociedade. Mas essas reações têm se tornado raras, diante do enfraquecimento moral das normas tradicionais - a própria desconfiança nas instituições públicas como a Justiça, que gera o senso comum de que nenhum político será punido, é uma das características desde enfraquecimento.

É como se, para algumas pessoas, os escândalos políticos fossem rotineiros. Segundo Thompson (2002), mesmo com o desinteresse prático da população em relação a alguns escândalos, o que em algumas situações se reflete no voto, a dramatização e a espetacularização da notícia - como descrito na introdução - garantem a audiência. "A maioria se diverte um pouco em ver um ministro com as calças caídas” (p.47).

Sobre isso, um dos exemplos relacionados ao Mensalão que podemos citar foi o levantamento publicado por Azevedo (2011) de que o caso não prejudicou a reeleição do ex-presidente Luiz Inácio Lula da Silva em 2006, após um ano da eclosão do escândalo.

Em 2006, a campanha adversária, do PSDB, focou seus argumentos nos desvios éticos do PT e na corrupção trazendo à memória o escândalo do Mensalão. Mas, segundo Azevedo (2011), a economia estava em situação satisfatória, principalmente para os eleitores mais pobres e "nova classe média" o que contribuiu para a reeleição de Lula. "Em outras palavras, o eleitor recompensa ou pune o governo pelo seu desempenho econômico" (Azevedo, 2011, p.90).

Porém, mesmo que as consequências de um escândalo não prejudiquem o cenário eleitoral, quando a mídia constitui um fato como escândalo político-midiático, é impossível 
controlar a divulgação do caso. O jornalismo se apropria dos discursos moralizadores e difamantes porque, de acordo com Thompson (2002), é isso que sustenta a cobertura. "Os atos de fala podem ser transmitidos a longas distâncias instantaneamente (...) que é extremamente difícil conter revelações prejudiciais" (p.49).

No universo dos roteiros dos seriados de TV dos e filmes, observa Rodrigues (2014), há sempre uma espécie de pensata em torno de todas as histórias. Conforme a autora, isso significa que por trás de cada narrativa há princípios morais embutidos. No caso da narrativa da Veja sobre o Mensalão, esses princípios seriam o combate à corrupção política, a necessidade punição dos envolvidos e liberdade para a imprensa investigar os casos.

O escândalo do Mensalão veio à tona, em 2005, com as entrevistas de Roberto Jefferson ao jornal Folha de São Paulo. Isso mobilizou investigações da mídia junto com órgãos fiscalizadores como Ministério Público Federal - MPF, com o objetivo de provar, por meio de documentos, que houve a compra de votos e quais seriam as outras pessoas envolvidas, além do núcleo político do PT: José Dirceu, José Genoíno (ex-deputado federal) e Delúbio Soares (então tesoureiro do PT) apontados como articuladores do esquema. Thompson (2002) afirma que, por temer processo por calúnia e prejuízo à credibilidade, os grandes veículos de comunicação, diante de um escândalo político, publicam o que consideram como evidência, que passam não só por documentos, mas fotografias ou gravações.

Segundo os autos do processo da Ação Penal $470^{4}$, referente ao Mensalão, as acusações dos 37 réus estão enquadradas no Direito Penal no que diz respeito a crimes praticados por funcionários públicos contra a administração em geral; crimes contra a paz pública; quadrilha ou bando; crimes previstos na legislação extravagante e crimes de "lavagem" ou ocultação de bens, direitos ou valores. José Dirceu foi denunciado por formação de quadrilha e corrupção ativa e condenado pelos dois crimes em 2012. A condenação por formação de quadrilha foi derrubada pelo plenário em 2013 após o réu ingressar com o recurso de embargos infringentes. Um dos argumentos da defesa foi o placar de seis votos a favor da condenação e quatro contras.

\footnotetext{
${ }^{4}$ Disponível em: http://www.stf.jus.com.br/portal/processo/verProcessoAdamento.asp?incidente $=11541 \mathrm{~h}$
} 
Leite (2013) reitera que o Mensalão foi considerado um caso de corrupção entre governo e parlamentares pela aprovação da Reforma da Previdência e isso foi sustentado pela mídia e Ministério Público Federal - MPF antes mesmo da conclusão das investigações e elaboração da denúncia ao Supremo Tribunal Federal - STF. Ao definir suborno e corrupção, Thompson (2002) lembra que os dois estão relacionados à troca de favores - quase sempre envolve dinheiro - para "influenciar decisões ou resultados em favor daquele que paga" (p.56).

Thompson (2002) explica que o ato de suborno só pode ser caracterizado como corrupção se a ação "envolve um funcionário público e que seu comportamento constitui uma perversão dos padrões de integridade tida como necessária aos que desempenham uma função pública". (p.56). Para chegar ao nível de escândalo na cobertura midiática, o caso precisa envolver muito dinheiro irregular ou desviado e um nome importante da instituição investigada.

O escândalo do Mensalão, de acordo com a denúncia do $\mathrm{MPF}^{5}$ envolveu R\$ 141 milhões e o comando e articulação do esquema foi atribuída a José Dirceu, ministro Chefe da Casa Civil, o cargo mais próximo das funções do presidente da República. "A Casa Civil é o braço operacional da presidência, com a missão de promover a governança intra e interministerial, compatibilizando os atos submetidos ao presidente da República às diretrizes governamentais" (Queiroz, 2009, p.94).

Portanto, a reputação de José Dirceu como figura pública foi colocada à prova após a eclosão do Mensalão. Thompson (2002) explica que o escândalo é capaz de gerar o clima de desaprovação em cima dos políticos apontados como envolvidos. Isso ocorre por meio das manchetes dos jornais, avaliações e críticas negativas da imprensa e caricaturas humilhantes repetidas pelos meios de comunicação que "viram a mesa dos líderes políticos" (Thompson, 2002, p.152) e evidenciam o que está por trás de uma "auto apresentação cuidadosamente gerenciada" (p.140).

Para Thompson (2002), escândalos também trazem à tona questões relacionadas a caráter, retidão, legalidade na classe política em geral. "É um reflexo do fato de que parte

\footnotetext{
${ }^{5}$ Disponível em: http://www.s.conjur.com.br/dl/mensalão.pdf
} 
do que está em jogo é a credibilidade dos líderes, cuja reputação e bom nome foram questionados pelo desenrolar do escândalo ou pela ameaça de sua divulgação" (p. 140).

“A reputação de caráter, em contrapartida, é um tipo de reputação que alguém consegue por ser uma pessoa fidedigna e confiável, uma pessoa de probidade e integridade" (Thompson, 2002, p.297). Da mesma forma que a confiança, a reputação demora para ser conquistada e reconhecida, mas rapidamente pode ser esvaziada com o escândalo, por ser um recurso não-renovável. No caso dos políticos com alta visibilidade, que era o caso de José Dirceu, a reputação pode ser contestada. "Uma reputação manchada pode permanecer assim para sempre" (p.298-299).

O político apontado como agente ou promotor dos atos que culminaram no escândalo também corre o risco de ter sua credibilidade abalada entre os próprios aliados que "podem começar a se afastar, temerosos de serem atingidos devido ao fato de estarem ligados a eles" (p.140). Podemos ver em Pereira (2012), Villa (2012) e Leite (2013) as especulações da imprensa sobre um eventual afastamento político do então presidente Luiz Inácio Lula da Silva de José Dirceu, que foram valorizadas pela mídia quando Lula fez um pronunciamento no dia 12 de agosto de 2005. Na ocasião, o presidente disse que não teve conhecimento sobre esquema do Mensalão e estava se sentindo traído ${ }^{6}$.

Thompson explica que partidos e governos se tornaram vulneráveis ao esvaziamento de reputação principalmente porque precisam travar lutas altamente competitivas por apoio eleitoral. "Um dano a sua reputação impede sua capacidade de conseguir objetivos" (p. 301). Por isso, a reputação do político é um dos critérios para que os partidos escolham seus candidatos, de forma que não afetam as estratégias "para quem quer competir no exercício do poder" (Thompson, 2002, p.151).

Além disso, o escândalo pode fortalecer os representantes da oposição ao político ou governo atingido pelas acusações. Diz Thompson (2002) que alguns políticos "procuram cada vez mais fazer crescer o capital político a partir de falhas de caráter dos outros" (p.148).

\footnotetext{
${ }^{6}$ Disponível em: https://www.youtube.com.br/watch?v=Qj-w3i9_hpq
} 


\section{3 - A Estrutura Sequencial dos Escândalos aplicada ao caso Mensalão}

O escândalo político-midiático também possui uma sequência de fases, que pode variar, avisa Thompson (2002), de acordo com o contexto e local: 1) pré-escândalo, 2) fase do escândalo, 3) o clímax e 4) as consequências. "A maioria dos escândalos reais comportam uma variedade de outros elementos e detalhes que aumentam grandemente sua complexidade (...) o desdobramento de um escândalo se torna um tipo de narrativa com múltiplas tramas e subtramas" (Thompson, 2002, p.52).

Aqui podemos fazer uma relação entre o desenvolvimento de um escândalo midiático e as narrativas. Segundo o autor (2002), o tempo de sua durabilidade depende de muitos fatores, entre eles, o ritmo das organizações de mídia que possuem padrões distintos de publicação e difusão. Ao longo da cobertura aparecem fatos novos, motivados pela investigação de órgãos como o Ministério Público e a Polícia Federal, e os episódios se acumulam em sequência. "O desdobramento dos escândalos midiáticos é entrelaçado por um constante contar e recontar histórias sobre os acontecimentos ou supostos acontecimentos presentes no centro do escândalo" (p.102)

Villa (2012) faz uma linha histórica dos principais acontecimentos relacionados ao auge do escândalo do Mensalão. $\mathrm{O}$ caso se desdobrou e permaneceu constantemente nos veículos de comunicação de maio de 2005, quando foi publicada a edição da revista Veja com a denúncia de propina nos Correios (ver introdução), a abril de 2006 quando foi aprovado o relatório da CPI dos Correios - o assunto será detalhado mais adiante.

Vemos aqui a semelhança entre a organização narrativa dos escândalos políticos e a narrativa seriada estudada por Rodrigues (2014) cujo modelo predominante advém dos programas de televisão norte-americanos ${ }^{7}$. Sob o aspecto da crítica literária, Todorov (1971) enumera três características presentes na narrativa: encadeamento, alternância e encaixamento, que surgem na disposição temporal de uma só história.

Portanto, o escândalo do Mensalão possui um núcleo narrativo (a compra de votos no Congresso e os personagens principais envolvidos) mas foi relacionado pela mídia a outros episódios ocorridos ao longo da cobertura. Um dos mais emblemáticos foi flagrante de dinheiro na cueca do assessor do irmão de José Genoíno (PT/SP).

\footnotetext{
${ }^{7}$ Mais detalhes sobre este aspecto serão desenvolvidos no capítulo teórico-metodológico.
} 
A partir da estrutura sequencial do escândalo midiático, proposta por Thompson (2002), podemos identificar resumidamente as principais etapas do escândalo do Mensalão entre 2005 e 2006 :

- "A fase pré-escândalo pode envolver a publicação da informação que subsequentemente acabará sendo relevante para um escândalo" (p.104). Podemos então considerar que a edição de Veja sobre o recebimento de propina nos Correios pelo PTB foi a fase préescândalo do Mensalão em 2005.

- “O escândalo propriamente dito começa com a divulgação pública de uma ação ou acontecimento que coloca em ação o processo de afirmações e contra afirmações” (p.104). O escândalo do Mensalão e seus desdobramentos na imprensa começaram a partir das entrevistas de Roberto Jefferson ao jornal Folha de São Paulo, em junho de 2005, quando aponta José Dirceu como articulador do esquema.

- Ainda no auge do escândalo "são conformados pelo padrão específico de revelações, alegações, e denúncias que vão se desdobrando na mídia” (p. 104). Começam as investigações da Polícia Federal e da Comissão Parlamentar Mista de Inquérito - CPMI dos Correios e a atuação do Conselho de Ética e da Corregedoria da Câmara (Guazina, 2013, p.9) para tentar comprovar a ocorrência da compra de votos. Os grandes veículos de comunicação, entre eles, a revista Veja, acompanham esse trabalho e publicam as informações.

- "Os indivíduos colocados no centro do escândalo procurarão virar a mesa contra imprensa, acusando os jornalistas de sensacionalismo, de adotar práticas antiéticas ou de baixar o nível no debate público" (Thompson, 2002, p.104). A pesquisa realizada por Guazina (2011) traz os episódios, entre julho e agosto de 2005, em que José Dirceu acusa a TV Globo de "linchamento moral", e a emissora responde as acusações por meio de editoriais no Jornal Nacional como forma de defender sua credibilidade e jornalismo (ver Guazina, 2013, p.13).

- "A terceira fase de um escândalo político midiático é o clímax. A fase culminante pode levar a uma confissão de culpa uma renúncia, uma demissão ou instauração de um processo criminal” (Thompson, 2002, p.105). Dois momentos que marcaram o escândalo do Mensalão podem ser relacionados à terceira fase. A demissão de José Dirceu do cargo 
de ministro da Casa Civil em 16 de junho de 2005 e a cassação de seu mandato de deputado federal em $1^{\circ}$ de dezembro do mesmo ano.

- "A quarta e última fase são as consequências - o período em que o calor do drama do escândalo e seu desenlace passaram, quando jornalistas se engajam em uma reflexão sobre os acontecimentos e as implicações” (p.106). A consequência culminante do escândalo do Mensalão foi o julgamento em 2012, pelo Supremo Tribunal Federal, dos 37 réus que figuravam na denúncia do Ministério Público Federal - MPF, de terem participado do esquema. Desses 37, 25 foram condenados.

Neste capítulo, fizemos um resumo das origens e consequências do escândalo político midiático e como a cobertura jornalística sobre esses casos pode impactar na relação de confiança entre os cidadãos e políticos. Também relacionamos a estrutura sequencial dos escândalos com o Mensalão e utilizamos das constatações de Thompson sobre a reputação dos políticos envolvidos em escândalos.

No próximo capítulo, será traçado um breve histórico do escândalo do Mensalão e da cobertura da Veja sobre o caso. Em seguida, vamos fazer a contextualização da presença de José Dirceu na trajetória da revista que dedicou dez capas ao ex-ministro após o escândalo do Mensalão. 


\section{CAPÍTULO III}

\section{VEJA, JOSÉ DIRCEU E O ESCÂNDALO DO MENSALÃO}

Este capítulo tem como objetivo traçar um histórico da revista Veja, que foi fundada em 1968, mesmo período em que José Dirceu começou a ter visibilidade política no movimento estudantil em São Paulo. Recorremos a análises já realizadas por outros autores da cobertura da revista sobre as manifestações dos estudantes em 1968, a campanha presidencial de 2002, quando Dirceu já era apontado como o segundo homem mais poderoso do futuro governo Lula e, de forma mais específica, a respeito do escândalo do Mensalão com foco na cobertura de Veja sobre o caso no auge, em 2005, e nos anos posteriores que englobam o período de publicação das edições que serão analisadas (2011, 2012, 2013 e 2014).

\section{1 - Histórico da Revista Veja}

Inspirada nos modelos de revistas semanais norte-americanas e de alguns países da Europa, Veja foi lançada no dia 8 de setembro de 1968 pelo proprietário da Editora Abril Vitor Civita e seu filho, o jornalista Roberto Civita.

O formato da revista, menor em tamanho com a prevalência de textos longos, causou estranheza aos leitores. Veja levou seis anos para se consolidar no mercado editorial, principalmente após criar um departamento de assinaturas, como explica Corrêa (2008).

Hoje, Veja é considerada a quarta maior revista semanal do mundo, como afirma Corrêa (2008). Também possui a maior tiragem entre publicações semanais no Brasil (1 milhão 124 mil 197 exemplares) ${ }^{8}$.

Para Corrêa (2008) e Almeida (2008), Veja trouxe muitas inovações para o jornalismo na época. Criar uma revista semanal seria um desafio e o projeto levou um ano para se concretizar. A Editora Abril organizou um curso de jornalismo ${ }^{9}$ para selecionar os

\footnotetext{
${ }^{8}$ Dados de 2014, acessados em 27/10/2014, disponível em (http://www.publiabril.com.br/tabelasgerais/revistas/circulacao-geral/imprimir)

${ }^{9} \mathrm{O}$ ex-professor da FAC-UnB José Salomão Amorim foi professor do curso de profissionais da Veja
} 
repórteres e já contava com uma equipe experientes de editores, entre eles, o jornalista Mino Carta. "O cursinho intensivo era destinado a quem não era jornalista ainda, mas a qualidade do curso também atraiu muita gente formada" (Almeida, 2008, p.27).

Ao aceitar o cargo de diretor de redação, Mino Carta, como aponta Almeida (2008), exigiu autonomia editorial. Porém, os dois proprietários deixaram claro qual seria o direcionamento ideológico da revista. Em depoimento a Almeida (2008), Roberto Civita disse que não iria interferir no dia-a-dia da redação, mas sempre estabeleceu grandes linhas. "Você não pode ter uma editora achando que a livre iniciativa é a solução para o país e ter uma redação que acredita que o ideal é acabar com o lucro" (p.26).

O produto pioneiro teria um custo alto: tratava-se de uma revista informativa com notícias atuais, mas também trazia reportagens mais elaboradas em plena Ditadura Militar. Apontam Coelho e Valle (2008) que o sucesso da revista mensal Realidade, também da Editora Abril, que existia desde 1966 e se utilizava de um jornalismo de atualidade mais próximo do literário, preparou o caminho para a criação de Veja: "Os diretores da editora passaram a acreditar na viabilidade econômica do lançamento de uma revista semanal" (p.140). A revista projetada também precisava se diferenciar de uma das concorrentes da Editora Abril, a revista Manchete, que tinha tom mais sensacionalista e maior espaço para fotos.

Almeida (2008) que realizou levantamentos sobre a censura política sofrida por Veja na Ditadura Militar, afirma que a revista foi um "um dos veículos de comunicação que mais sofreu retaliação do regime” (p.19). Segundo a autora, a saída da censura na rotina produtiva da publicação, em 1976, pode ser considerada um dos marcos do processo de redemocratização em relação à imprensa brasileira a partir do governo de Ernesto Geisel. Segundo Almeida (2008), todos os veículos de comunicação, grandes, pequenos ou alternativos, sofreram algum tipo de censura na Ditadura Militar, mesmo aqueles que apoiaram o Golpe em 1964. Mesmo assim, “A Editora Abril teve uma rica contribuição no modo de fazer jornalismo em um Brasil sob regime de exceção” (p.15).

Em sua pesquisa, Almeida (2008) catalogou 138 matérias de Veja que foram censuradas entre os anos de 1969 e 1976. Um dos momentos mais tensos ocorreu em 1969, quando a revista começou a publicar matérias detalhadas sobre os métodos de tortura 
contra os presos pela Ditadura. De acordo com Almeida (2008), inicialmente a censura se dava por meio de telefonemas e bilhetes até os censores se instalarem na redação para fazerem a leitura prévia das matérias e assim vetá-las ou cortar as partes de textos que seriam "incômodas" ao governo.

A partir da abertura democrática, Veja se destacou nas reportagens sobre a anistia, da campanha das "Diretas Já" pelas eleições diretas a presidente em 84 e responsável pela divulgação de Fernando Collor de Mello o "Caçador de Marajás" (edição 1020 23/03/1988) e (edição 1078 - 17/05/1989) como a nova força política contra a corrupção, o que fortaleceu o político para ganhar as eleições para presidente em 89, segundo afirma Conti (1999).

Em 1992, a revista foi decisiva para o impeachment de Collor, (ver Waisbord, 2000, p.100) ao publicar uma entrevista do irmão do presidente Pedro Collor de Mello que divulgou um dossiê com os números de contas bancárias no exterior assinadas por Paulo César Farias. Até aquele momento, as evidências da culpabilidade de Collor no esquema ainda eram fracas, mas a entrevista de Pedro para Veja "moveu a investigação para uma nova fase" (Waisbord, 2000, p.100).

A diferença ideológica com o governo Lula (2002-2010) e com o PT foi outro destaque na história da revista. Conforme o trabalho de Araújo (2013), não só a discordância ideológica de Veja em relação ao PT marcou a cobertura do escândalo e do julgamento do Mensalão, mas também o fato de a revista se colocar como porta-voz de uma comemoração do povo brasileiro, por exemplo, pela condenação dos réus (Araújo, 2013, p.44 - 45).

Baseado em Goffman (1959), Araújo (2013) argumenta que as revistas brasileiras, entre elas, a Veja, atuaram de forma a construir discursivamente a imagem dos atores sociais envolvidos durante a cobertura do julgamento da AP 470. Em nossa visão, essa construção se dá desde as primeiras denúncias do escândalo e sua extensa cobertura em 2005. Para o autor, "a certeza de que um esquema de compra de parlamentares nos primeiros anos do governo Lula realmente existira, constituiu o 'quadro simbólico' nuclear da abordagem" (2013, p. $44-45)$. 


\section{2 - Veja X José Dirceu: o Movimento de 1968 e o começo dessa história}

Na visão de Coelho e Valle (2008), a linha editorial de Veja ainda era marcada pela ambiguidade durante a eclosão do Movimento de 1968, quando José Dirceu começou a ter destaque como líder estudantil na resistência contra Ditadura. Os autores afirmam que a combinação atual da revista onde prevalece as posições políticas conservadoras e ideologicamente de direita com matérias de comportamento e saúde ainda não existia na iniciante Veja de 1968: "Em sua fase inicial oscilou entre o engajamento político e o jornalismo de entretenimento" (p.139).

A primeira edição da revista já demonstrava que a política seria uma das tônicas em suas coberturas mesmo com as eventuais limitações impostas pela Ditadura Militar. Com fundo vermelho e a imagem de uma foice e um martelo trazia a chamada: "o grande duelo do mundo comunista", se referindo a disputa entre chineses e soviéticos (Coelho e Valle, 2008, p.146).

A cobertura de Veja do Movimento Estudantil em 1968 foi realizada em meio a essa oscilação, de acordo com Coelho e Valle (2008). Veja destacou a atuação e comportamento de dois protagonistas deste momento: Vladimir Palmeira, líder estudantil no Rio de Janeiro, e José Dirceu, presidente da União Estadual dos Estudantes de São Paulo - UEE. Por meio de pesquisa histórica, os autores constataram que a revista noticiou a tensão daquele momento sob a ótica dos confrontos de rua entre os estudantes e a polícia; retratou os líderes como celebridades, "expondo suas vidas pessoais" (p.144) e incentivavam a procura por culpados pela violência, utilizando "fórmulas de jornalismo espetacular" (p.143). Essas evidências se mostraram principalmente nas chamadas de capa e os títulos das matérias.

Outra percepção da análise de Coelho e Valle (2008) é que o sensacionalismo e o espetacular, presentes na cobertura de Veja sobre os fatos que marcaram a resistência estudantil à Ditadura, estão relacionadas à lógica mercantil para a venda de produtos com apelo às emoções que despertam interesse do público. Dentro dos estudos da narrativa, que trataremos no capítulo posterior, é a definição semelhante ao efeito de sentido, citado por Motta (2013), uma das intencionalidades do narrador. "O interesse por intermédio de 
sensações como amor, ódio, desejo, medo, coragem, repulsa, curiosidade é principal característica da imprensa sensacionalista" (p. 147).

Em Veja, a visibilidade de José Dirceu em 1968, que estudava Direito na Pontifícia Universidade Católica - PUC/SP, transitava entre a sua fama de "namorador" e "bonitão", inclusive com os apelidos "Ronnie Von das massas" e "Alain Delon dos pobres" com os questionamentos sobre sua capacidade de liderar os estudantes, principalmente após o episódio conhecido como "Batalha da Rua Maria Antônia", que foi matéria de capa na edição 5 , de 9/10/68.

Durante a "Batalha" cerca de três mil estudantes da Universidade Mackenzie e 2.500 da Faculdade de Filosofia da Universidade de São Paulo - USP se enfrentaram fisicamente na rua Maria Antônia. Um estudante da USP levou um tiro e morreu. A violência foi auge das disputas ideológicas entre os grupos estudantis de esquerda e os de direita, como o Comando de Caça aos Comunistas - CCC. Coelho e Valle (2008) ressaltam que a cobertura de Veja enfatizou que o José Dirceu seria um dos responsáveis pela violência na Maria Antônia por incentivar os estudantes a enfrentar a repressão policial para "aumentar a divulgação do movimento" (p.149).

Em seguida, também em 1968, ele surge em outra matéria de capa (edição 6) que trata do $30^{\circ}$ Congresso da União Nacional dos Estudantes - UNE em Ibiúna (SP) que foi descoberto pela polícia e levou Dirceu, um dos candidatos à presidência da entidade, à prisão. Para Coelho e Valle (2008), em seu enredo, Veja representou personagens do movimento estudantil como perigosos, por isso, denunciados pela revista, e transpareceu que o fracasso de Ibiúna e a prisão dos envolvidos seria um alívio e "um ponto final na luta contra o terrorismo" (Coelho e Valle, 2008, p.151). A revista destacou que UNE era clandestina pois havia sido extinta em 1964, que os líderes enganaram a polícia várias vezes e associou o Congresso com as “peculiaridades do terrorismo em 1968” (p.150).

A conclusão de Coelho e Valle (2008) é que a revista Veja colaborou para instaurar um clima de medo na população com a ideia prevalente de que protestos de 1968 contra a Ditadura estariam perdendo o controle, usando elementos de entretenimento em seu jornalismo. A expectativa seria que, com a prisão dos líderes, o presidente Costa e Silva não endureceria o regime e a censura, mas isso acabou acontecendo com o Ato 
Institucional - AI-5. "Ao assinar o AI-5, ele se transformou, de salvador da Pátria em bandido, vilão da imprensa e da narrativa construída por Veja” (p.152).

\section{3 - "O homem que faz a cabeça de Lula"}

Ao longo de sua história, até os dias atuais, Veja dedicou 15 capas a José Dirceu, dez delas, as que serão analisadas na presente pesquisa, são relacionadas ao Mensalão: auge do escândalo, o que estaria fazendo após o escândalo que provocou a cassação de seus direitos políticos, julgamento da Ação Penal - AP 470 no STF e prisão.

O ex-ministro fez parte da cobertura da revista Veja em vários momentos da história política brasileira. A primeira capa em que ele aparece é de 1969, na edição 53, durante a Ditadura Militar, quando foi libertado junto com outros presos políticos após o resgate do embaixador americano Charles Elbrick. Anteriormente, como já foi explicado, ele recebeu destaque nos conflitos envolvendo o Movimento Estudantil de 1968.

Após ser solto, José Dirceu passou uma temporada em Cuba, onde afirma em Dirceu e Palmeira (1998), ter participado de um treinamento para guerrilha. Ele acabou optando pela clandestinidade. Para isso, fez plásticas no rosto e voltou para o Brasil com outro nome: Carlos Henrique Gouveia de Melo.

Na década de 80, após a anistia e durante o processo de redemocratização do país, pode reassumir sua identidade e passou a ser considerado um dos líderes da nova geração da esquerda conforme descreve Markun (2004). Também por participar da criação do Partido dos Trabalhadores - PT cujo principal fundador foi Luís Inácio Lula da Silva, líder sindical que havia comandado as greves no ABC Paulista no final dos anos 70. Ao voltar, Dirceu conta em Dirceu e Palmeira (1998) que precisou recomeçar a vida quase do nada: trabalhou como funcionário da Assembleia Legislativa de São Paulo e concluiu a faculdade de Direito na PUC.

Na década de 1990, requereu, na Câmara dos Deputados, junto com Eduardo Suplicy (PT/SP), a realização da Comissão Parlamentar de Inquérito - CPI que investigou o esquema de corrupção de Paulo César Farias, tesoureiro de campanha do Fernando Collor de Melo que culminou no impeachment do presidente. 
Krieger at al (1992) destaca que Dirceu sofreu ameaças nesse período, vindas da área militar, para desmoralizá-lo e assim desqualificar a investigação, que estava alimentando a cobertura jornalística do caso. "Dirceu foi acusado de ser um agente da KGB (serviço secreto russo) e organizador de um núcleo gay do serviço de espionagem inglês" (Krieger at al, 1992, p.141). As informações foram publicadas em uma reportagem no jornal BSB Brasil que costumava publicar matérias pagas pelo Palácio do Planalto.

Após o caso Collor, Dirceu representou a oposição aos governos de Itamar Franco (1992-1994) e de Fernando Henrique Cardoso (1995-2002), que havia derrotado Lula em duas eleições presidenciais. Nesse período, ele se destacou, como presidente do PT e deputado federal, por suas críticas à privatização da Telebrás, da política econômica de FHC e foi um dos incentivadores da "Passeata dos Cem Mil" realizada em 1999, na Esplanada dos Ministérios, em Brasília, que pedia a saída de Fernando Henrique do poder (Markun, 2004, ps.296 e 303).

Mas foi nas eleições de 2002 que Veja voltou a dar atenção a José Dirceu. Com a possibilidade da vitória de Lula para a Presidência da República, a revista reinicia sua vigilância sobre o futuro ministro-chefe da Casa Civil, uma das características da imprensa nas democracias liberais, como afirma Thompson (2002), que mantém fiscalização sobre os políticos.

Na matéria da edição 1770/2002 com a chamada "O homem que faz a cabeça do Lula", Veja faz referência sobre a função de José Dirceu como articulador da campanha presidencial do PT naquele ano. O ex-ministro era o presidente do Partido desde 1995 e a revista o descrevia como pragmático e autoritário em relação às tendências mais radicais do partido.

Porém, é interessante destacar que nesta matéria, de forma semelhante ao que aconteceu em 1968, Veja novamente questiona a capacidade de liderança de José Dirceu em um eventual governo petista, conforme descreve Dobbeck (2003), que enumera várias características do discurso da revista sobre o ex-ministro naquela ocasião. Entre elas, podemos destacar o julgamento de caráter de José Dirceu como político a partir das histórias sobre sua vida pessoal, inclusive, durante seu exílio e clandestinidade que duraram de 1969 a 1979, quando foi decretada a anistia. 
É possível observar essa ideia na chamada da matéria: “voz moderada do PT, exlíder estudantil José Dirceu foi preso pelo regime militar, treinou guerrilha em Cuba e fez até plásticas no rosto para despistar a polícia” (Veja, 2002, p.46).

Prevalece na matéria, na visão de Dobbeck (2003), a descrição de José Dirceu como cabeludo, rebelde, bonitão e falante, de que ele praticava o amor livre e tinha várias namoradas simultaneamente. A revista se refere às histórias sobre ele como "lendas" e o compara com ídolos pop das décadas de 60 e 70, além de afirmar que Dirceu possui uma biografia mais interessante do que a de Lula.

De acordo com Dobbeck (2003), esse levantamento histórico da revista sobre Dirceu, ao noticiar que seria o homem poderoso do governo Lula, leva o leitor a entender que ele seria egoísta, não teria limites para alcançar objetivos e abandona as pessoas quando não lhe servem mais. A entrevista da primeira esposa de Dirceu, Clara Becker, é utilizada na matéria para comprovar isso.

Dirceu se uniu a Clara na década de 70 com a identidade de Carlos Henrique Gouvêa de Melo. Os dois tiveram um filho em 76, mas em 79, Dirceu precisaria voltar a ser ele mesmo com a anistia e teve que contar a verdade a ela e o casamento acabou (ver Cabral, 2013, p.112).

Com essa matéria, analisada por Dobbeck (2003), Veja enfatiza que Dirceu poderia ser o sucessor de Lula. Entende-se então que o personagem é relevante para o agendamento político e midiático da revista e isso se refletiu na cobertura do escândalo do Mensalão.

\section{4 - "O Chefe da Quadrilha”: a cobertura de Veja sobre o Mensalão e José Dirceu}

A seguir, vamos fazer um resgate histórico sobre o escândalo do Mensalão e assim traçarmos aqui os assuntos recorrentes na cobertura de Veja a respeito do caso, principalmente no que se refere às matérias sobre José Dirceu na revista e as funções atribuídas a ele no escândalo.

Guazina (2011) lembra que o escândalo do Mensalão esteve presente na cobertura midiática brasileira durante um ano (maio de 2005 a abril de 2006). Como já mencionado na introdução, as denúncias sobre o caso começaram a partir de uma matéria publicada na 
edição 1905 da revista Veja, de 18/05/2005, com denúncia sobre corrupção na Empresa Correios e Telégrafos - Correios.

O caso ganhou repercussão no Jornal Nacional, da TV Globo, em função de um vídeo - produzido por uma câmera escondida - em que o chefe do Departamento de Administração e Contratação dos Correios Maurício Marinho, ligado ao PTB, aparece recebendo R\$ 3 mil em dinheiro vivo de um interlocutor. "O vídeo levantou suspeitas sobre a negociação do governo e os partidos da base aliada", (Guazina, 2011, p.97).

No vídeo, Marinho diz que Jefferson tem conhecimento do esquema: "Eu não faço nada sem o consultar. Tem vez (sic) que ele vem pro Rio de Janeiro só pra acertar um negócio" (Villa, 2012, p.20). Villa (2012) afirma, com base nas matérias jornalísticas da época, que o vídeo foi produzido por empresários que pretendiam ser fornecedores dos Correios. Para isso, deveriam pagar propina a Marinho.

Em contrapartida à matéria de Veja, Roberto Jefferson deu duas entrevistas ao jornal Folha de São Paulo nas edições de 06/06/2005 e 11/06/2005 concedidas à colunista Renata Lo Prete. O deputado mencionou pela primeira vez o termo "Mensalão" nome dado por ele ao denunciar que o governo comprou votos da base aliada para a aprovação de matérias do Poder Executivo.

Villa (2012) afirma que as revelações de Jefferson à Folha também teriam sido motivadas por uma entrevista dada por José Dirceu ao programa Roda Viva, da TV Cultura, no dia 16 de maio. Para os jornalistas, o então ministro chefe da Casa Civil disse que não via "necessidade de prestar solidariedade ao deputado Roberto Jefferson" (p.50).

Guazina (2011) destaca que, nas entrevistas à Folha, Jefferson faz as revelações que nortearam o núcleo narrativo do escândalo do Mensalão: que o dinheiro seria não contabilizado (caixa dois) e gerado pela "arrecadação de recursos ilegais para campanhas eleitorais" realizadas pelo publicitário mineiro Marcos Valério, também apontado por realizar transações semelhantes em campanhas do PSDB mineiro. (p.98).

José Dirceu foi mencionado por Jefferson, na entrevista do dia 11, entre os ministros do governo Lula que não só teria conhecimento do esquema do Mensalão, como participado das negociações sobre cargos. O líder do PTB revelou que também teria feito o 
alerta ao presidente Lula. De acordo com Cabral (2013), a partir desse momento, Dirceu começou a ser pressionado pelo Palácio do Planalto, por ter sido um dos responsáveis pela formação da base aliada, a pedir demissão da Casa Civil (Cabral, 2013, ps.242-245).

Mas antes da entrevista de Jefferson, o escândalo gerado pela matéria de Veja sobre a "propina dos Correios" já estava movimentando o Congresso Nacional. A reação foi imediata. No dia seguinte à publicação da matéria, os parlamentares da oposição iniciaram a coleta de assinaturas pela abertura de uma Comissão Parlamentar Mista de Inquérito CPMI no Congresso Nacional para investigar o caso. O Ministério Público Federal - MPF também abriu inquérito civil na mesma semana para averiguar as denúncias da revista (Villa, 2012, ps.50-51).

Após a demissão da Casa Civil, quando reassumiu o mandato de deputado federal, Dirceu foi envolvido em outras denúncias oriundas de investigações e depoimentos da CPMI, o que agravou a crise política que estava vivenciando. Apesar de Roberto Jefferson tê-lo citado em suas entrevistas à Folha, foi a mulher de Marcos Valério, Renilda Fernandes de Souza que, ao depor na CPMI, afirmou que o ex-ministro se reunia com o seu marido, sabia de todo o esquema e teria encontrado com representantes dos bancos BMG e Rural, acusados de operar transações financeiras fraudulentas para abastecer o Mensalão (Villa, 2012, p. 39; Cabral, 2013, p.259).

Na edição 1916, de 3 de agosto de 2005, Veja publicou matéria sobre o registro de que Roberto Marques, assessor de Dirceu, teria sacado R\$ 50 mil do Banco Rural no dia 13 de junho de 2004, em Belo Horizonte (MG). A informação teria sido dada pessoalmente a Dirceu, antes de ser veiculada, pelo presidente da CPMI dos Correios, o senador Delcídio Amaral (PT/MS) como afirma Cabral (2013).

Em entrevista ao jornal Folha de São Paulo na edição de dia 3 de agosto de 2005, Roberto Jefferson disse que José Dirceu articulou de negociações com a empresa Portugal Telecom para a "liberação de fundos para pagamento de dívidas dos partidos (PT e PTB) em campanhas eleitorais". Segundo Jefferson, a negociação também envolveu Marcos Valério (Guazina, 2011, p.100; Villa, 2012, p.79).

As acusações que pairavam sobre os atos atribuídos a Dirceu no esquema também envolveram sua vida pessoal com a revelação, vinda da CPMI, de que sua ex-mulher 
Ângela Saragoça teria contraído empréstimos dos bancos envolvidos na investigação do Mensalão. Uma das consequências foi abertura do processo de cassação de Dirceu.

Apesar da recomendação de colegas para renunciar ao mandato, ele decidiu enfrentar o processo no Conselho de Ética e a votação da cassação em plenário. Afirmou ser inocente, que as provas eram insuficientes paras as acusações contra ele, que não era homem de "fugir à luta pela porta de trás" (ver Cabral, 2013, p.263). Cabral (2013) também destaca, afirmando estar baseado em depoimentos de amigos do ex-ministro, que Dirceu se sentiu abandonado pelo PT e por Lula durante a crise do Mensalão.

Leite (2013) aponta que a culpa de Dirceu não foi registrada pela Polícia Federal PF e que os fatos apurados pela instituição durante as investigações do caso não foram capazes de incriminá-lo. "Não há provas contra ele, não há uma denúncia nem uma testemunha" (p.50). O jornalista completa que Roberto Jefferson, por exemplo, não relatou um caso específico ou uma situação precisa envolvendo o ex-ministro à PF.

Cabral (2013) sistematizou as acusações enfrentadas por Dirceu que constam no relatório do Conselho de Ética indicando a cassação, que viriam também basear a denúncia do MPF e os crimes (Corrupção Ativa e Formação de Quadrilha) para os quais o exministro foi acusado e julgado no STF (Cabral, 2013, p.270):

- Comandar o pagamento do Mensalão;

- Compactuar com falsos empréstimos bancários ao PT;

- Tráfico de influência para beneficiar sua ex-mulher;

- Ajudar um banco com crédito consignado;

- Contemplar outro banco com investimentos de fundos de pensão;

- Defender interesses patrocinados por Marcos Valério;

- Ter um assessor na lista de beneficiados com dinheiro irregular arrecadado por Marcos Valério.

Além dos mandatos de José Dirceu e Roberto Jefferson, o plenário da Câmara cassou os mandatos de mais nove deputados denunciados como integrantes do esquema 
durante a CPMI. Ao todo, o Conselho de Ética recomendou cassar 19. Quatro foram absolvidos e outros quatro renunciaram, entre eles José Genoíno (PT/SP), que também renunciou à presidência do PT, e Paulo Rocha (PT/PA), (Guazina, 2011, p.100).

Abaixo, por meio de linha histórica, estão relacionados os principais acontecimentos do escândalo do Mensalão e seus desdobramentos da cobertura da revista Veja, e onde estão inseridas as edições das revistas que serão analisadas na presente pesquisa. A linha histórica é baseada na cronologia de Villa (2012), em informações de Cabral (2013) e na sequência de edições de Veja que está no acervo digital da revista.

2005

18/05 - Na edição 1905, Veja publica a matéria sobre a propina recebida pelo diretor dos Correios, Maurício Marinho, do PTB, de fornecedoras que pretendiam assinar contratos com a empresa.

19/05 - José Dirceu diz, em entrevista ao programa Roda Viva, da TV Cultura, que não prestará solidariedade a Roberto Jefferson em relação às denúncias de Veja e que é contra a criação de uma CPI.

25/05 - Veja, na edição 1906, publica matéria sobre o corretor Henrique Brandão, amigo de Roberto Jefferson e dono de uma seguradora que teria fechado contratos milionários com diretorias ocupadas por indicados pelo PTB em Furnas, Infraero e Eletronuclear. (Villa, 2012, p.31).

26/05 - O ministro chefe da Casa Civil José Dirceu critica os parlamentares do PT que apoiaram a criação da CPMI dos Correios em entrevista ao Jornal Nacional, da TV Globo. (Villa, 2012, p.58).

03/06 - Veja publica em seu site o áudio de uma entrevista realizada com Lídio Duarte, expresidente do Instituto de Resseguros de Brasil, em que ele dá mais detalhes sobre como seria o esquema de favorecimentos do PTB em relação aos cargos que ocupava. Segundo Lídio, os indicados deveriam recolher R $\$ 400$ mil ao partido mensalmente. (Villa, 2012, p. 62) 
06/06 - Em entrevistas à colunista Renata Lo Prete, do jornal Folha de São Paulo, Roberto Jefferson revela a existência de um esquema de mesada para parlamentares da base aliada paga pelo PT. Ele afirma que avisou ao presidente Lula, a José Dirceu e a outros ministros do governo Lula sobre o que chamou de "Mensalão". Os ministros da Integração Nacional, Ciro Gomes e das Comunicações Miro Teixeira confirmaram as afirmações do líder do PTB (Villa, 2012, p.63).

9/06 - Após vários conflitos entre parlamentares do PT, da base aliada e da oposição é instalada a CPMI dos Correios.

16/06 - José Dirceu deixa o cargo de ministro chefe da Casa Civil e reassume seu mandato de deputado federal.

22/06 (primeira edição a ser analisada) - Na edição 1910, Veja publica matéria sobre os bastidores da demissão e como o presidente Lula estaria reagindo ao momento mais difícil de seu governo. (Ver anexos, Figura 1).

29/06 (segunda edição a ser analisada) - Veja, em matéria de capa na edição de 1911, afirma que o Mensalão destruiu a imagem ética do PT e que o partido estaria se apropriando da estrutura do Estado para beneficiar seus integrantes, entre deles, José Dirceu. Um dos textos aponta que o ex-ministro da Casa Civil representava um fantasma de ideais que morreram. (Ver anexos, Figura 2).

06/07 - Veja publica, na edição 1912, matéria sobre um empréstimo de R $\$ 2,5$ reais do banco BMG ao PT com assinatura do presidente do partido José Genoíno. Segundo a revista, o avalista da operação foi Marcos Valério.

30/06 - Roberto Jefferson depõe na CPMI dos Correios e mesmo sem apresentar provas afirma que o dinheiro do Mensalão, arrecadado por Marcos Valério, era sacado do Banco Rural.

26/07 - Em depoimento para a CPMI dos Correios, a esposa de Marcos Valério Renilda Fernandes de Souza relata que presenciou encontros de José Dirceu e com o seu marido para negociar os empréstimos do PT feitos às empresas de Valério. 
02/08 - É realizada acareação no Conselho de Ética da Câmara dos Deputados entre José Dirceu e Roberto Jefferson, um dos ápices da cobertura do escândalo, segundo Cabral (2013). O líder do PTB acusou Dirceu de negociar quitação de saldos de campanhas do PT com a Portugal Telecom. O ex-ministro negou. Foi nesse momento que Jefferson disse que tinha medo de Dirceu e que ele despertava seus "instintos mais primitivos". (Cabral, 2013, p. 262).

03/08 (terceira edição a ser analisada) - Na edição 1916, Veja põe José Dirceu na capa e, na matéria principal, aponta que ele estaria fazendo ameaças diretas a Lula e a cúpula do PT para sobreviver politicamente. Outra matéria revela que, a partir de documentos da investigação da CPMI dos Correios, que Roberto Marques, assessor do ex-ministro da Casa Civil, teria sacado 50 mil da conta de Marcos Valério no Banco Rural. (Ver anexos, Figura 3).

Nesse mesmo dia, segundo Cabral (2013), a CPMI revelou que a ex-mulher de Dirceu Ângela Saragoça teria conseguido empréstimos dos bancos apontados como envolvidos no Mensalão. $\mathrm{O}$ autor afirma que, nesse momento, Dirceu teria dito a amigos que não escaparia de um processo de cassação.

10/08 - Conselho de Ética instaura processo de cassação de mandato contra José Dirceu.

11/08 - Depoimento de Duda Mendonça à CPMI dos Correios. O publicitário revelou que recebeu mais de $\mathrm{R} \$ 11$ milhões, em pagamento do PT pela campanha de 2002, oriundo de caixa 2.

12/08 - Lula afirma em discurso transmitido em rede nacional que não sabia da existência do Mensalão, se sentia traído, e que o PT precisava pedir desculpas ao povo brasileiro.

24/08 - Na edição 1919, Veja veicula matéria com a denúncia do doleiro Toninho da Barcelona de que o Banco Rural operava uma conta bancária clandestina do PT no exterior.

14/09 - Roberto Jefferson tem o mandato cassado pela Câmara dos Deputados.

30/10 - Veja veicula matéria sobre acusações de que o PT teria recebido doações clandestinas vindas de Cuba para a eleição de Lula em 2002. O PFL (hoje DEM) e o PSDB pedem que o TSE investigue as denúncias (Villa, 2012, p.88). 
01/12 - Câmara cassa o mandato de José Dirceu por 293 votos a 192.

2006

05/04 - O relatório da CPMI dos Correios é aprovado. A Comissão concluiu que o Mensalão existiu, mas sem conseguir provar o envolvimento do presidente Lula (Villa, 2012, p.94). A Comissão teve o auxílio da Polícia Federal - PF e do Ministério Público Federal - MPF e outros órgãos nas investigações ${ }^{10}$.

16/04 - Em sua edição número 1952, Veja repercute a denúncia do MPF em sua matéria de capa em que chama Lula de "sujeito oculto" do Mensalão. A revista se refere aos acusados como "40 ladrões de dinheiro público".

2007

28/08 - O Supremo Tribunal Federal - STF aceita a denúncia do Ministério Público Federal - MPF de julgar os 40 acusados de envolvimento no esquema do Mensalão. A relatoria ficou a cargo do ministro Joaquim Barbosa. Dirceu seria julgado por formação de quadrilha e corrupção ativa.

05/09 - A revista Veja dedica a capa da edição 2024 a Joaquim Barbosa e o chama de "herói" no combate à "impunidade dos corruptos".

\section{1}

31/08 (quarta edição a ser analisada) - Cinco anos após a denúncia do MPF ser aceita pelo STF, período em que o Mensalão saiu dos destaques da imprensa, Veja publica mais uma matéria de capa, na edição 2232, onde afirma que Dirceu estaria conspirando contra a presidente Dilma Rousseff mesmo sem exercer cargo público. Com o título de "O Poderoso Chefão", a reportagem, com o uso de câmeras escondidas, registra nomes importantes do governo Dilma e do PT que teriam sido recebidos por Dirceu em um quarto de hotel em Brasília. (Ver anexos, Figura 4).

\footnotetext{
${ }^{10}$ Na semana seguinte, o então procurador Geral da República Antonio Fernando Barros e Souza impetra a denúncia referente ao escândalo do Mensalão no Supremo Tribunal Federal - STF. O Ministério Público Federal - MPF acusou 40 pessoas de envolvimento no suposto esquema, entre eles, José Dirceu e concluiu que o Mensalão foi resultado de uma "organização criminosa". A denúncia está disponível em: file://C:/Users/usuaRIO/Downloads/INQ\%202245\%20\%20denuncia\%20mensalao.pdf
} 
06/06 - STF marca o início do julgamento da Ação Penal - AP 470, conhecida como julgamento do Mensalão, para o dia $1^{\circ}$ de agosto.

01/08 (quinta edição a ser analisada) - A reportagem especial de Veja sobre o início do julgamento do Mensalão (AP 470) traz José Dirceu na capa na edição 2280, com o título "Réu", aponta os possíveis planos do ex-ministro em caso da eminência de condenação, entre eles, até a fuga para outro país. (Ver anexos, Figura 5).

19/09 - Veja publica a matéria de capa "Os segredos de Valério", na edição 2287, sobre supostas revelações de Marcos Valério a respeito do escândalo do Mensalão diante da possibilidade de ser condenado a mais de 100 anos de prisão na AP 470. Segundo a revista, o publicitário teria dito que "não sobrou para o Lula" porque ele, José Dirceu e Delúbio Soares não falaram.

10/10 - José Dirceu é condenado pelo STF por corrupção ativa.

22/10 - José Dirceu é condenado pelo STF por formação de quadrilha. Já tinham sido condenados o ex-presidente do PT José Genoíno e Delúbio Soares, ex-tesoureiro do partido.

12/11 - STF define que José Dirceu deverá cumprir pena de 10 anos e 10 meses de prisão pelos crimes de corrupção ativa e formação de quadrilha.

17/12 - STF realiza última sessão do julgamento da AP 470. Dos 38 reús, 25 foram condenados.

\section{3}

12/06 (sexta edição a ser analisada) - O jornalista Otávio Cabral, que foi editor de Veja na sucursal de Brasília, lança o livro "Dirceu, a biografia". A matéria de capa, na edição 2325, é uma resenha da publicação que faz um resumo da vida de José Dirceu de acordo com o autor: o manipulador político, homem de negócios e condenado pelo Mensalão que “sequestrou, teve múltiplas identidades e chantageou Lula". (Ver anexos, Figura 6).

18/09 - O STF decide que José Dirceu, José Genoíno e Delúbio Soares teriam direito a um novo julgamento por formação de quadrilha. Isso ocorreu porque as defesas dos réus 
ingressaram com o recurso dos embargos infringentes que pode ser concedido a condenados pelo STF por um voto de diferença, como foi o caso de Dirceu, condenado por seis votos a cinco.

15/11 - José Dirceu se entrega à Polícia Federal para início de cumprimento da pena de sete anos e onze meses de reclusão em regime semi aberto por corrupção ativa, após o STF decretar a prisão dos condenados na AP 470. O novo julgamento sobre formação de quadrilha estava previsto para o ano seguinte.

20/11 (sétima edição a ser analisada) - Na edição 2348, Veja repercute a prisão de José Dirceu, José Genoíno, Delúbio Soares e outros réus do Mensalão na capa. (Ver anexos, Figura 7).

27/11 (oitava edição a ser analisada) - Na semana seguinte, Veja dedica outra capa a José Dirceu, José Genoíno e Delúbio Soares, na edição 2349. A revista afirma que os presos estariam tendo privilégios na penitenciária da Papuda, no Distrito Federal, para onde foram transferidos após se entregarem na PF em São Paulo. (Ver anexos, Figura 8).

\section{4}

27/02 - José Dirceu, José Genoíno e Delúbio Soares são absolvidos do crime de formação de quadrilha pelo plenário do STF. Dessa forma, o ex-ministro não precisaria cumprir pena em regime fechado.

05/03 (nona edição a ser analisada) - Na edição 2363, Veja repercute a absolvição de Dirceu, Genoíno e Delúbio na matéria de capa, como "melancólica". Ao invés de fotografia, a revista se utiliza de uma charge dos três condenados fazendo alusão ao carnaval que iniciaria naquela semana: "quanto riso, oh, quanta alegria", trecho de marcha carnavalesca, de autoria de Zé Kéti e Pereira Matos, foi a chamada da capa. (Ver anexos, Figura 9).

19/03 (décima edição a ser analisada) - Veja dá destaque à rotina de José Dirceu na prisão e traz uma foto do ex-ministro que teria sido tirada na biblioteca da penitenciária da Papuda, onde ele trabalhava, na capa da edição 2365. A revista trata novamente dos supostos privilégios. (Ver anexos, Figura 10). 
26/06 - José Dirceu recebe autorização do STF para trabalhar em um escritório de advocacia em Brasília durante o dia e dormir na prisão.

28/10 - STF autoriza a Dirceu a cumprir pena em regime domiciliar. O ex-ministro estava residindo em Brasília. Mas em agosto de 2015, ele foi preso novamente, dessa vez, acusado de participação em um esquema de propina da Petrobras, conhecido como Petrolão

Portanto, analisaremos um total de 12 matérias publicadas em 10 edições de Veja, referentes aos dias 22/06, 29/06, 03/08 de 2005; 31/08/2011; 01/08/2012; 12/06, 20/11 27/11 de 2013; 05/03 e 19/03 de 2014.

No próximo capítulo, serão detalhados os aspectos teóricos e metodológicos da pesquisa. 


\section{CAPÍTULO IV}

\section{PERCURSO TEÓRICO E METODOLÓGICO}

\section{1 - Aspectos Teóricos}

Para melhor compreensão e sistematização dos aspectos teóricos será feita uma divisão das categorias que serão consideradas na análise das doze matérias escolhidas para compor a presente pesquisa. Nosso objetivo principal, conforme mencionado anteriormente, é identificar como se constitui a narrativa jornalística da revista Veja sobre o personagem José Dirceu durante e após o escândalo do Mensalão entre os anos de 2005 e 2014.

O trabalho se baseia na afirmação de Tuchman (1993) de que as notícias são estórias construídas pelos repórteres diante de acontecimentos reais e de Motta (2013) que encontrou nas teorias da narratologia - o conjunto de estudos lingüísticos sobre as narrativas - modelos de interpretação das notícias, definidas, em seus estudos, como narrativas jornalísticas. As principais características dos roteiros das narrativas seriadas e fílmicas, levantadas por meio dos estudos de Rodrigues (2014) e Vogler (2006), também compõe o referencial teórico-metodológico porque, ao longo das análises, observou-se o uso de estratégias de linguagem semelhantes à destas mídias pela revista Veja na estruturação e enredo das matérias.

A divisão se dará da seguinte forma: primeiro vamos apresentar as principais características das narrativas jornalísticas e conceitos relacionados à sua estrutura e elementos baseados nos autores da narratologia. Em seguida, serão enumeradas as funções dos personagens das notícias, mais especificamente, no jornalismo político e como isso pode se relacionar com as narrativas da TV e do cinema. As estratégias argumentativas e intencionalidades do narrador concluirão o levantamento. Vamos olhar mais detidamente sobre as narrativas jornalísticas a fim de compreender melhor o processo de construção dos personagens jornalísticos; isto é, para apreendermos os múltiplos sentidos das funções dos personagens, devemos observá-los dentro do contexto das narrativas noticiosas. 
A narrativa jornalística - De acordo com Tuchman (1993), os relatos de acontecimentos noticiosos são estórias e "localizam temas e conflitos de uma sociedade particular" (p.258). A socióloga norte-americana, baseada nas etnografias que realizou, também afirma que, com a rotina nas redações, os jornalistas aprendem um conjunto de normas técnicas e se utilizam de valores- notícias, também propostos por Traquina (ver capítulo 1), para contar e recontar as mesmas estórias dando a elas enquadramentos diferentes. "Dizer que a notícia é uma história não é de modo algum rebaixar a notícia, nem acusá-la de ser fictícia” (p.262).

Uma das técnicas exigidas ao repórter é a de identificar o lead - o primeiro parágrafo das matérias que contém as informações mais importantes. A partir de então, cabe a ele organizar os parágrafos sobre um mesmo fato que será relatado de outras formas por outros profissionais. Esse critério de seleção depende de vários fatores desde a linha editorial do veículo até as características culturais de quem escreve. Para Tuchman (1993), mesmo com a presunção de que o jornalista se baseia na objetividade, imparcialidade e isenção - valores-notícia compartilhados na comunidade jornalística - não se pode desconsiderar de que o jornalista é um contador de histórias e que a notícia é uma realidade construída. "Os relatos noticiosos, mais uma realidade seletiva do que uma realidade sintética, como acontece na literatura, existem por si só" (p.262).

Na visão de Bird e Dardenne (1993), os relatos noticiosos são culturalmente construídos e há dificuldade no meio profissional jornalístico de compreender o valor narrativo das notícias principalmente em função da defesa da objetividade. "Os dispositivos retóricos e estruturais são vistos simplesmente como métodos de transmitir informação com precisão e eficácia" (p.263). Segundo os autores, as notícias é um gênero específico do sistema simbólico e é necessário compreender "o contexto no qual os jornalistas constroem estórias" (p.264).

Os autores apontam o mito e o folclore como parte da construção narrativa das notícias. Mesmo sendo relatos de acontecimentos reais, trazem à tona valores préestabelecidos, definem o bem e o mal, além de provocar emoções nos membros de uma cultura por meio de "um conjunto de tradições e crenças populares" apontam Bird e Dardenne (1993, p.266). 
Bird e Dardenne (1993) exemplificam essa ideia com o jornalismo policial. Podemos fazer uma analogia com a cobertura política em relação aos escândalos. De acordo com eles, os leitores não se interessam pelos crimes para se manterem bem informados e então se precaverem. "Em vez disso, as histórias tornam-se parte de uma estória ou mito mais amplo acerca do crime e valores" (p.276), o que faz, por exemplo, os casos mais impactantes como os assassinatos, serem noticiados em detrimento a situações mais rotineiras como pequenos furtos ou roubo de carros.

Os assassinatos trazem à tona os valores da piedade, da desolação e do medo de perder um ente querido, identificaram os autores. Na política, os escândalos políticos, baseado nos estudos de Thompson (2002), provocam as sensações de impunidade, revolta e desconfiança no poder público, na política e nos políticos, além de serem priorizados no enquadramento da cobertura jornalística. "Os jornalistas têm de que fazer o news judgements rapidamente e recorrem inevitavelmente aos enquadramentos existentes" (Bird e Dardenne,1993, p.276).

Tuchman (1993) categoriza as notícias em hard, as informativas e factuais, e soft, aquelas que dão ao repórter mais espaço para escrever reportagens de interesse humano, entretenimento ou comportamento. Para Motta (1993), é mais fácil para o analista identificar nas notícias soft os elementos de uma narrativa como o enredo, as sequências, intrigas e personagens. No gênero hard os textos são mais diretos, fragmentados e inconclusos e "reúnem informações dispersas sobre um mesmo tema ou assunto" (Motta, 2013, p.97).

Segundo Motta (2013), as notícias são narrativas factuais, que se propõem a relatar os fatos de maneira mais próxima possível do real e "procura estabelecer reações lógicas e cronológicas das coisas físicas e das relações humanas reais ou fáticas" (idem, p.89).

As narrativas fáticas ou de ficção estão presentes nos romances, contos, novelas, filmes, geram efeito de verossimilhança (Gancho, 2002. p.10). O leitor acredita no que lê mesmo a história sendo imaginária. No caso do jornalismo, Motta (2013) afirma que há entre o narrador e o destinatário um contrato cognitivo baseado na credibilidade. "É delegado ao jornal e ao jornalista-narrador a autoridade e legitimidade para dizerem a verdade sobre fatos reais" (p.39). 
Conforme Mota (2012), quando a narratologia examina objetos de comunicação, sai da teoria literária para uma análise mais ampla ao nível das relações culturais, atos de fala em contexto, práticas sociais e culturais e, dessa forma, examina relatos impregnados de narratividade, "enunciando uma sucessão de estados de transformação, que ocorrem muitas vezes por conta de conflitos entre os personagens, pelo jogo de sentidos em busca de hegemonia" (Mota, 2012, p.12).

Podemos concluir, com esses estudos, que a construção das narrativas jornalísticas possui características próprias relacionadas à cultura, aos valores-notícias e à comunidade profissional, mas podem ser analisadas sob a ótica estrutural. Utilizaremos aqui os conceitos de Todorov, a sistematização presente em Gancho (2002) e Abdala Junior (1995) e os estudos de Motta (2013) sobre narrativa jornalística.

Narrativas são compostas pelos elementos, segundo lista Gancho (2002): enredo, personagens, tempo, espaço, ambiente e narrador e são separadas por gêneros (romance, novela, conto e crônica, por exemplo) e tipos de narrativa (épica, lírica e dramática). Como o objeto de análise é a narrativa jornalística, alguns elementos utilizados em análise literária não serão utilizados.

A presente análise se concentrará inicialmente nos elementos. O enredo é o "conjunto de fatos de uma história" (p.9) que é estruturado pelo conflito, definido por Gancho (2002) como "qualquer componente da história que se opõe a outro, criando uma tensão que organiza os fatos da história e prende a atenção do leitor” (p.11). Um desses conflitos pode ser moral e envolver um personagem, que entendemos ser uma das características da narrativa da revista Veja sobre José Dirceu. Também já tratamos no capítulo 2 a importância do conflito para as coberturas políticas.

No caso do jornalismo, de acordo com Motta (2013), a maioria das matérias diárias não possui começo, meio e fim definidos. Então, o analista precisa reunir todos os fragmentos, "que podem estar separados por intervalo de dias, semanas ou meses no noticiário" (p.97). Na análise literária, é possível relacionar as características do conto e da crônica com as narrativas jornalísticas. Abdala Júnior (1995) aponta que, nesses gêneros, o autor precisa concentrar efeitos de impacto no leitor em textos menores, omitir o que não 
for essencial e "apresentar pontos de vista entre a voz do narrador e as vozes das personagens que não se afastem do tema central” (p.18).

Analisaremos matérias da revista Veja separadas entre os anos de 2005 e 2014 que abrange a maior parte enredo sobre escândalo do Mensalão, onde é possível traçar um ciclo histórico do personagem que será estudado. "A recorrente presença de personagens, conflitos e cenários nos autoriza a unir as partes" (Motta, 2013, p.98)

Todorov (1971) também enumera categorias da narrativa literária que podem ser utilizadas em análises de narrativa jornalística. Ele afirma que as narrativas são ao mesmo tempo história e discurso e aparecem em um universo povoado pelas obras já existentes, raciocínio semelhante ao de Bird e Dardenne (1993) em relação à influência dos mitos na construção narrativa da notícia.

Segundo os estudos de Todorov (1971) sobre o tempo da narrativa, o enredo pode ser constituído de encadeamento, alternância e encaixamento quando várias histórias se ligam em uma única trama. Isso ocorre principalmente em romances ou novelas, segundo o autor. Mas a narrativa jornalística pode ser fragmentada, como já mencionamos, então, compreende-se que essas três situações podem ocorrer na construção da narrativa jornalística e poderão ser observadas pelo analista, de acordo com Motta, no momento de recompor o acontecimento-intriga.

Na visão de Motta (2013), sem uma análise rigorosa, os incidentes relatados pelo jornalismo permanecem fragmentados, confusos, difusos pois estão imersos em metanarrativas maiores. "Com a análise, a realidade imediata adquire novos clímax, suspenses, desenlaces de histórias sucessivas que se encaixam em novos episódios” (p.107).

Todorov (1971) explica que o encadeamento é a justaposição de diferentes histórias: "uma vez acabada a primeira, começa-se a segunda e a unidade é assegurada neste caso por uma semelhança de construção de cada uma" (p.236). Já o encaixamento, é um tipo de combinação em que uma história é incluída em outra, mas sua existência depende do enredo central. A alternância consiste em "contar duas histórias simultaneamente, interrompendo ora uma, ora outra, para retomá-la na interrupção seguinte” (p.236). 
A alternância foi observada na análise com o uso de quadros e boxes que tratam de questões relacionadas ao acontecimento-intriga, porém nem sempre relacionados ao núcleo narrativo. Por exemplo, se o núcleo narrativo é a prisão de Dirceu, Veja usa um boxe para contar a história de um outro condenado no julgamento do Mensalão ou de outro escândalo político. Já o encaixamento é constatado quando ao invés de abrir as matérias com o que seria o fato mais importante a ser noticiado e assim desenvolver a história, a revista inicia os textos narrando histórias do passado recente. Seria uma estratégia para situar o leitor, o que comprova que a narrativa sobre José Dirceu durante e após o escândalo do Mensalão obedece uma continuidade.

O tempo e o espaço são dois elementos da narrativa literária que podem ser utilizados pelos jornalistas nas matérias soft, muito frequentes no jornalismo de revista. Há mais espaço para descrição do espaço físico onde se desenrola o acontecimento. Já o ambiente reúne também as características sociais, psicológicas presentes no local e no momento com os personagens envolvidos na história. Abdala Júnior (1995) destaca que o ambiente pode ser um elemento "útil a continuidade do conflito, constituindo índices, isto é, informações reveladoras".

Sobre o tempo, Motta (2013) aponta que as notícias contam a história do presente. Os jornalistas relatam fatos recentes - em matérias de jornal impresso podem ser divulgadas no dia seguinte ou semanas depois, dependendo do assunto - em tempo real ou horas depois como é o caso da rádio, da TV e da internet. "Parte do pressuposto de que percebemos e construímos o sentido do presente como uma história, como uma continuidade entre o que está acontecendo com o que acabou de acontecer” (Motta, 2013, p. 104).

As matérias de revista, a exemplo da Veja, quando não exploram um fato novo, um furo, repercutem os assuntos da semana anterior. Para Abdala Junior (1995), quando a distância entre o tempo do narrador e do leitor é pequeno, prevalece na narrativa o tempo histórico, mas isso não significa que a história não vai se desenvolver em torno do tempo psicológico, quando "o tempo cronológico é distorcido em função das vivências subjetivas das personagens" (p.54). 
Sobre o narrador há várias diferenças entre as narrativas fáticas e as de ficção. As matérias jornalísticas, como afirma Motta (2013), principalmente na categoria hard, exigem um narrador em terceira pessoa, também chamado de "narrador observador" ou “narrador onisciente" por (Gancho, 2002, p.27). Portanto, precisa ser mais objetivo e direto, manter determinada distância dos fatos, dos entrevistados e de outras pessoas envolvidas no acontecimento. Mas como já explicamos, esses valores também compõem o mito da objetividade, como vimos em Biroli (2010). Porém, nas notícias soft isso pode variar, pois, segundo Motta (2013), o jornalista "ganha liberdade para imaginar e sugerir no texto efeitos estéticos de sentido" (p.95). Então, percebemos em publicações brasileiras como a revista Piauí, textos em que os repórteres relatam os fatos, mas falam também sobre a experiência vivida na apuração, sobre os seus sentimentos e ações em relação a si mesmo ou aos personagens e ambientes. Com base em Gancho (2002), esses são exemplos de "narrador testemunha", "narrador personagem" ou "narrador parcial" (ps.27-28).

A onisciência e a onipresença dos narradores, citados por Gancho (2002) entre os componentes da análise literária, também variam, porque, de acordo com as observações ao longo da pesquisa, o jornalista não é o único narrador da história: precisa dos relatos das fontes e entrevistados. Nas matérias de Veja, outro elemento se mostrou evidente: o narrador principal, além de onisciente, é intruso, divulga seus posicionamentos e juízos de valor a respeito dos fatos.

Porém, sabemos que não é possível o repórter estar em todos os lugares (onipresente) onde se passam os acontecimentos que pretendem organizar na matéria e também, provavelmente, não tem conhecimento integral (onisciência) sobre o acontece, aconteceu e acontecerá, pois, lida diariamente com a imprevisibilidade. O escritor de ficção se utiliza da criação e imaginação próprias sobre o enredo e possui mais controle sobre a narrativa. "No jornalismo não existe ordem clara nem fixa entre a informação nova que entra e as informações internas que o próprio sujeito ativa no ato" (Motta, 2013, p.100).

O levantamento teórico sobre construção do personagem como elemento da narrativa jornalística, que compõe um dos objetos centrais do presente estudo, será detalhado a seguir. 
Personagens - Mesquita (2003) realizou estudos em que utiliza elementos de análise literária para traçar a construção das personagens jornalísticas. Segundo ele, a criação de personagens é comum aos vários tipos de narrativa e também parte essencial da jornalística e midiática. “Os jornalistas gostam de propor imagens simplificadoras das pessoas" (p.125).

O personagem, como elemento das narrativas, é quem realiza a ação no enredo, de acordo com Gancho (2002), e podem ser planas (que possuem poucos atributos e suas características e não passam por transformações complexas ao longo da história) e redondos (quando a história apresenta uma variedade maior de características, podendo ser físicas, psicológicas, sociais, ideológicas e morais).

Citados por Motta (2013), os teóricos a seguir definem o personagem. Gerald Prince (1987) o conceitua como um ser dotado de traços antropormórficos e realça sua representação humana. Na visão de Reuter (2002), os personagens são elementos chave na estória e capazes de gerar identificação dos leitores em relação ao que é narrado. Também diz que toda estória é uma intriga entre eles.

Sobre o papel desempenhado pelos personagens, o que Propp (2001) classifica como funções, é possível identificar quem são os protagonistas e antagonistas, estrutura utilizada nas matérias jornalísticas principalmente quando se trata de política, onde predomina o conflito e está presente na cobertura do escândalo do Mensalão. Mesquita (2003) aponta que as figuras heróicas e também anti-heróicas compõem os modelos de identificação das personagens jornalísticas.

A partir das observações sobre a cobertura jornalística, podemos afirmar que a imagem de José Dirceu, por exemplo, foi construída ao longo dos anos pela mídia brasileira por causa de sua biografia, muito semelhante ao que Campbell (1997) conceitua como ciclo do herói. Essa representação sofreu uma ruptura a partir do momento em que Dirceu passou a articular a eleição de Lula nas eleições presidenciais de 2002, chegou ao poder como ministro chefe da Casa Civil e se consolidou com os crimes atribuídos a ele no "Mensalão", o que nos faz concluir que ele se tornou um anti-herói.

Para Campbell (1997), o herói pode ser determinado pelas seguintes características: alguém que se destaca, é mais forte que os outros seres ou possui poderes mágicos, capaz 
de salvar os fracos e oprimidos. Faz parte, principalmente, das histórias de ficção, quadrinhos ou mitológicas. Porém, a presença de heróis nas narrativas jornalísticas tem sido constante. Pode ser representado, dando exemplo, por um bombeiro, policial ou anônimo que salva vidas em um incêndio ou soterramento.

O herói, por conseguinte, é o homem ou mulher que conseguiu vencer suas limitações históricas e pessoais e locais e alcançou formas normalmente válidas, humanas. As visões, ideias e inspirações dessas pessoas vêm diretamente das fontes primárias da vida e do pensamento humano. (CAMPBELL, 1997, p.29)

Segundo Propp (2001), folclorista russo, cuja obra "Morfologia do Conto Maravilhoso", é conhecida por extrair elementos semelhantes dessas narrativas, as ações ou funções dos personagens quase não mudam. Propp (2001) analisou que, nos contos, o inimigo é aquele que se apodera de bens, foge, sequestra, engana e quando se confronta com o herói, que representa a ética e os bons costumes, é vencido.

Em linhas gerais, eis algumas das constatações de Propp (2001): ao herói é feito o pedido para reparar um dano, ele aceita o desafio e decide ir; em seguida ele é submetido ao ataque do inimigo ou antagonista; depois reage a esse ataque quando recebe poderes mágicos ou a ajuda de outros personagens para vencer o antagonista; mesmo após a vitória e o regresso, o herói sofre perseguições, consegue se salvar e reinicia sua busca até reparar o dano e ser reconhecido pelo feito.

Diferente de Propp (2001) que estudou os contos do folclore russo, Campbell (1997) traçou as características comuns nos rituais dos heróis da mitologia grega, da civilização judaico-cristã e de religiões em países como Índia e Japão e como isso influencia no imaginário coletivo das pessoas.

A narrativa jornalística em torno de José Dirceu o apresenta como um personagem que exerce determinadas funções de acordo com o contexto histórico em que está inserido, principalmente, por ter tido destaque na política brasileira em vários momentos de sua trajetória, criando ao seu redor uma espécie de imaginário.

De acordo com Campbell (1997), o ciclo do herói - semelhante aos resultados dos estudos de Propp (2001) - segue os seguintes padrões: nascimento, chamado, jornada aliada a uma luta norteada por sacrifícios e amor, capazes de revolucionar a vida do próprio herói e das pessoas a sua volta. A jornada é marcada por dificuldades que são superadas. 
A primeira tarefa do herói consiste em retirar-se da cena mundana dos efeitos secundários e iniciar uma jornada pelas regiões causais da psique, onde residem efetivamente as dificuldades, para torná-las claras, erradicá-las em favor de si mesmo e penetrar no domínio da experiência e da assimilação, diretas e sem distorções. (CAMPBELL, 1997, p.12)

O autor lembra o que acontece com o herói que consegue alcançar o seu objetivo. Quando não há reconhecimento pela bravura, ele pode ser perseguido - afirmação levantada também por Propp (2001) - e sofrer por isso.

Se o herói, em lugar de submeter-se a todos os testes da iniciação, tiver simplesmente alcançado seu alvo (pela violência, pelo engenho ou pela sorte) e levado à graça obtida para o mundo que ele desejou, então os poderes que desequilibrou podem reagir tão violentamente que ele será destruído tanto a partir de dentro como de fora - crucificado. (CAMPBELL, 1997, p.20)

Mesquita (2003) enumerou as modalidades de identificação presentes nas personagens jornalísticas, baseadas em H.R.Jauss (2002): a identificação por simpatia, cujo objeto é o herói imperfeito cujas fraquezas levam ao sentimento de compaixão; a identificação irônica, quando o herói é eliminado na narrativa ou é substituído por um antiherói. Há também as identificações admirativas quando se trata de um herói perfeito; catártica, quando o herói está em dificuldade ou associativa quando personagem assume um papel em situação dramática ou competição.

Ao citar Carlos Reis (1995), Mesquita (2003) aponta que o personagem pode ser realçado durante determinado momento de sua vida, mas isso pode ser modificado ao longo das emissões, e ele desaparecer ou se tornar subalterno. "A personagem é considerada um lugar ideologicamente marcado, área privilegiada de investimento de valores e visões de mundo" (Mesquita, 2003, p.131).

Conforme Mesquita (2003), os personagens jornalísticos, são pessoas reais, que inseridos na narrativa jornalística são retratados, principalmente quando há em volta deles consensos ao assumirem situações de liderança ou de idolatria. "O personagem é também uma reconstrução do leitor (...) aos seus olhos, a personagem existe no quadro de uma narrativa que torna plausível sua representação", (p.132). Mesquita (2003) considera que essa representação é fragmentada e que os traços biográficos de figuras públicas como os políticos são selecionados pelo jornalismo. "Não conheceremos delas nunca senão aquilo que os mídia dizem a seu respeito" (p.133). 
Sobre isso, Motta (2013) concorda com Mesquita (2003), e afirma que os personagens quando narrados pelo jornalismo não se tratam de pessoas reais e, sim, figuras do discurso. Motta (2013) completa que o posicionamento dos personagens no enredo pode evidenciar as manipulações discursivas do narrador que o recobrem de significações para enquadrá-los em seus desejos e intenções.

A crítica de Mesquita (2003) vem ao encontro dessa fabricação de personagens da notícia incentivar a invasão de privacidade. Vimos em Thompson (2002) que a invasão de privacidade pode manchar a reputação de uma figura pública de forma irreversível em contextos de escândalos que levam a espetacularização da notícia. "Fica evidente a premeditação rumo aos efeitos de sentido pretendidos, incluindo os truques para estimular a identificação entre personagens da estória e a audiência” (Motta, 2013, p.186).

Mesquita (2003) defende que o personagem jornalístico é construído a partir dos critérios de escolha do autor propostos pelo real, quando ordena os dados de acordo com o objetivo da narrativa. "O jornalista possui uma ampla margem de liberdade ao modelar o retrato de determinada personalidade" (p.135). Ele considera as novas tecnologias de informação estimulam a construção de personagens.

É interessante destacar que Mesquita (2003) faz um paralelo entre a construção de personagens e a política. Segundo ele, as transformações das instituições públicas refletem nas mudanças estruturais das notícias e reportagens. "A personagem jornalística é um elemento estruturante, não só da narrativa midiática, mas também do próprio sistema político" (p.137). Observamos uma convergência das ideias de Mesquita (2003) e Thompson (2002) ao considerar que as opções eleitorais têm sido baseadas no caráter de quem pretende alcançar um cargo público, ou seja, sobre a pessoa do candidato e não com “determinados temas e interesses" (Mesquita, 2003, p.137). Citamos aqui Traquina (1993) que considera a personificação um dos valores-notícias da comunidade jornalística.

Sobre a política, Motta (2013) exemplifica o caso do ex-senador Antônio Carlos Magalhães (DEM/BA), falecido em 2007, que ficou conhecido pela sigla ACM e o apelido de Toninho Malvadeza, por ter sido muito influente em seu estado e na região nordeste. Para Motta (2013), o noticiário sobre ACM era norteado por esses estereótipos e imaginários que podem gerar nos receptores a identificação de que o personagem é um 
herói ou um vilão. Esse é um dos objetivos da análise das matérias sobre José Dirceu durante e após o escândalo do Mensalão: identificar qual o imaginário criado em torno dele como figura construída entre o mundo da identificação e da projeção. "As notícias constroem conflitos, enredos, personagens, mocinhos, bandidos. O objeto da análise é a versão e não a história" (p.192).

De acordo com Mesquita (2003), a construção do personagem jornalístico começa com a negociação entre fonte e jornalista ao longo da apuração de informações que farão parte da notícia: documentos, testemunho de pessoas, observação e interpretação dos gestos dos personagens, bem como seus comportamentos e obras. "Não resulta de um mero trabalho de cópia ou reflexo da pessoa existente, mas da criatividade do jornalista, que lhe dá unidade, coerência interna e forma final” (p.140).

Mesquita (2003) concluiu, baseado nas idéias Freud, que a verdade biográfica das pessoas não é acessível e que os jornalistas deslocam sua subjetividade em relação aos assuntos noticiados aos personagens envolvidos na história que são retratados. Por isso, dez edições da revista Veja serão analisadas para identificar qual a representação de real que a revista atribui a José Dirceu entre os anos 2005 e 2014.

O personagem nas narrativas seriadas e fílmicas - Como já mencionado, esse item foi incluído na pesquisa a partir das observações da autora sobre as semelhanças de características das matérias de Veja com a estruturação dos roteiros dos seriados de TV (modelo norte-americano) e dos filmes que compõem a cultura popular, que possuem narrativas mais simples e atraentes aos olhos do público.

Vogler (2006) que atuou em estúdios de cinema nos Estados Unidos como avaliador de roteiros antes de suas execuções, desenvolveu um modelo técnico de elaboração de narrativas chamado de "A Jornada do Escritor". O autor se baseou nos estudos de Campbell (1997) sobre o "Ciclo do Herói” para traçar essa estruturação, cujo objetivo central é identificar o ciclo do personagem e suas funções na composição dos enredos.

O Ciclo do Herói norteia o inconsciente coletivo por isso é tão bem compreendido pelo público. Constatamos que os narradores de Veja, se utilizam de alguns desses elementos. "Todas as histórias consistem em alguns elementos estruturais comuns encontradas universalmente em mitos, contos de fada, sonhos e filmes" (Vogler, 2006, 
p.26). De acordo com o autor, essa relação estreita de identificação emocional entre o público e os personagens tem a ver com a definição de arquétipos. "O psicólogo suíço Carl G. Jung empregou o termo arquétipos para designar antigos padrões de personalidade que são uma herança compartilhada por toda a raça humana" (p.48).

Vogler (2006) destaca que os arquétipos são constantes através dos tempos e nas mais variadas culturas, presentes nos sonhos e na imaginação mítica. "Um narrador instintivamente escolhe personagens e relações que dão ressonância à energia dos arquétipos para criar experiências dramáticas reconhecíveis por todos” (p.48).

Portanto, os arquétipos são como funções que os personagens desempenham para obter efeitos de sentido nos destinatários, símbolos das várias qualidades humanas. "Pode se pensar nos arquétipos como máscaras, usadas temporariamente pelos personagens à medida que são necessárias para o avanço da história" (p.48). Rodrigues (2014) completa que a imaginação dos narradores, a exemplo dos roteiristas de TV e cinema, está impregnada do mito, suas características e etapas.

Estes são os arquétipos, de acordo com Vogler (2006):

1. Herói: possui história ligada a um sacrifício de si mesmo, transcende limites e ilusões, vive uma trajetória de rompimento ou separação, enfrenta inimigos para corrigir danos, lida com a morte e busca integralidade.

Para Vogler, os heróis precisam ter qualidades admiráveis para que as pessoas queiram ser como eles, para tornarem as narrativas interessantes e emocionantes (p.53).

Um personagem real, como uma pessoa real, não é apenas um traço, mas uma combinação única de muitas qualidades e impulsos, alguns deles conflitantes. E quanto mais conflitantes, melhor. Um personagem dilacerado por forças opostas, que o puxam em sentidos contrários para o amor e o dever (...) uma combinação única de impulsos contraditórios, como confiança e suspeita (Vogler, 2006, p.53).

No entanto, dentro do arquétipo de herói, existem variedades, conforme indica Vogler (2006): a exemplo do anti-herói que "não é o oposto de herói, mas um tipo especial de herói, alguém que pode ser um marginal ou um vilão, do ponto de vista da sociedade, mas com quem a plateia se solidariza" (p.58). Percebe-se, sob a ótica da revista Veja, que José Dirceu não deve suscitar nenhum tipo de solidariedade do público e que não evolui 
como personagem ao longo do recorte narrativo analisado. Por esse motivo, o ex-ministro se enquadra no conceito de anti-herói trágico.

São heróis com defeitos, que nunca conseguem ultrapassar seus demônios íntimos e são derrotados e destruídos por eles. Podem ser encantadores, alguns podem ter qualidades admiráveis, mas o defeito ganha no final. Alguns dos antiheróis trágicos não são tão admiráveis, mas observamos sua queda com fascínio. (Vogler, 2006, p.58)

2. Mentor: é o que ensina, dá presentes, motiva e dá informações ao herói. Até o mensalão, Dirceu exerce, para Veja, o papel de mentor de Lula. Na primeira fase do escândalo, ele se torna um anti-mentor, que tenta levar o herói para o caminho do crime e da destruição, como detalharemos no capítulo sobre a análises.

3. Guardião do Limiar: é uma espécie de vigia do vilão que precisa ser vencido pelo herói antes dele enfrentar o maior desafio, o bloqueia e testa seus poderes. Psicologicamente podem ser "neuroses, cicatrizes emocionais, vícios, dependências e autolimitações que seguram nosso crescimento e progresso" (p.72). Um herói bem-sucedido reconhece o guardião do limiar e até se alia com ele para conseguir o objetivo.

4. Arauto: é aquele que anuncia a necessidade de mudança, que envia mensagens ao herói. Pode ser uma pessoa ou uma força.

5. Camaleão: personagem que começa a história com uma função dramática, porém muda de acordo com as circunstâncias. Mudam fisicamente ou de estado de espírito. Induz o herói a dúvida ou à incerteza sobre sua sinceridade ou lealdade. "É uma máscara que pode ser usada por qualquer personagem (...) quando se deseja retratar personagens cuja aparência ou comportamento se alternam para satisfazer às necessidades da história" (p.82).

6. Sombra: desafia o herói e apresenta a ele um oponente a sua altura. "Quando o protagonista está paralisado pelas dúvidas ou culpa, age de modo autodestrutivo, manifesta vontade de morrer ou está inebriado pelo sucesso está tomado pela sombra” (p.84). Ajuda a compreender os vilões e antagonistas e aspectos do herói que ficam ocultos.

7. Pícaro: é o personagem que suaviza a história, provoca risos. "Quando estamos nos levando demasiadamente a sério, a parte Pícaro da nossa personalidade pode surgir de repente para nos devolver a necessária perspectiva” (p.87). 
Seguindo os passos propostos por Campbell (1997), Vogler (2006) propõe os seguintes estágios da jornada do herói: Um mundo Comum; Chamado à aventura; Recusa do Chamado; Encontro com o Mentor; Travessia do Primeiro Limiar; Testes, aliados e inimigos; aproximação da Caverna Oculta; provação; Recompensa; caminho de Volta; Ressureição e Retorno com o Elixir.

Sobre a narrativa seriada, Rodrigues (2014) trata do mundo inconfundível dos personagens, que insere o telespectador no universo de caracterização e da vivência dos protagonistas e coadjuvantes. Esse "mundo" precisa ser muito bem identificado para permanecer na memória do destinatário porque os seriados de TV, diferente dos filmes, prolongam a história em várias temporadas que levam até quase dez anos para serem concluídas. É o caso semelhante da narrativa sobre os escândalos políticos, que se estendem, e a função dos envolvidos, como ocorreu com José Dirceu na Veja, precisa se consolidar ao longo da trama.

Utilizamos esses estudos ao perceber que a análise da narrativa também permite encontrar similaridades entre a cobertura jornalística e o mundo da ficção. Isso não significa que os textos jornalísticos sejam invenções dos narradores, é uma questão de estrutura textual que, como já mencionamos, envolve construções culturais e mitológicas, que torna as histórias mais acessíveis ao público em geral. Os elementos da narrativa permanecem os mesmos, a despeito das singularidades com que são constituídos. Mesmo que o jornalismo se estabeleça a partir da referencialidade de fatos reais, a forma de organizar/estruturar a narrativa, dependendo do tema trabalhado, precisa por exemplo de personagens e enredo.

Para a autora (2006), que é roteirista, o mundo inconfundível é criado a partir dos elementos da narrativa: história, enredo, construção da trama e dos personagens para tornalo marcante. "Lugar, cenários, personagens, relação entre personagens, contexto cultural e valores morais são elementos do mundo inconfundível que garante a interação com o espectador e a verossemelhança" (p.35).

Ela acrescenta que os elementos do mundo inconfundível precisam estar evidentes. $\mathrm{Na}$ caracterização dos personagens, é importante constarem a profissão do protagonista, por exemplo, seus obstáculos na história e sua competência em resolver os problemas. $\mathrm{O}$ 
mundo inconfundível vai determinar em que direção os grandes temas como amor, sexo, dinheiro e poder vão conduzir os personagens.

Vogler (2006) diferencia o Mundo Comum do Mundo Especial que são duas etapas necessárias para que o personagem (que pode ser o heroí, o vilão ou outra função) possa sair de sua zona de conforto para partir em busca de um desafio. O Mundo Comum é aquele ainda sem conflitos, é a vida cotidiana.

Já o Mundo Especial é o que está em desequilíbrio, que precisa ser restaurado, é bomba-relógio que o público está sendo lembrado de que pode explodir, é o momento em que todas as saídas se fecham e o personagem precisa enfrentar a questão. "É sentido de modo diverso, tem outro ritmo, diferentes prioridades e valores, regras diferentes. Muitas vezes as coisas ficam perigosas e o preço dos erros é mais alto" (ps. 138 e 139).

Toda narrativa de ficção, de acordo com o Rodrigues (2014), possui as seguintes etapas: início, ruptura, perda, obstáculo, divisão, auxílio, decisão e conclusão, além de ter a capacidade de partilhar aventuras que as pessoas não viveram, mas gostariam de ter vivido. Isso possibilita a convivência com personagens que aumentam a compreensão do ser humano. Para ela, existem muitas fontes de histórias. "A primeira é a nossa própria vida. A segunda é a vida das pessoas próximas. A terceira é a vida da nossa cultura. A quarta é a literatura, o cinema, a TV e tudo o que fizeram antes de nós (p.19).

Rodrigues (2014) concorda com o Vogler (2006) de que as narrativas possuem vários elementos comuns, inclusive os arquétipos. Mas, conforme a autora (2014), o que determina o rumo dessas narrativas, a diferença entre elas, são "a localização do protagonista na sua sociedade, seu objetivo e o obstáculo existente [que] rendem uma história de curta ou longa duração ou uma história com muitas ou poucas possibilidades de ramificações” (Rodrigues, 2014, p.20).

Já algumas características das narrativas seriadas, elencadas por Rodrigues (2014) foram encontradas nas matérias da Veja analisadas nesta pesquisa. Foi uma sequência de 12 matérias que compõe uma narrativa que durou dez anos e é marcada pela trajetória do personagem José Dirceu e o surgimento de novos fatos no caso, investigações, nomes, julgamento e prisões. É por isso que em todas as análises foram identificados os 
acontecimentos-intriga e os núcleos narrativos de cada uma das matérias. De acordo com Rodrigues,

Toda narrativa seriada possui um núcleo narrativo. Tramas paralelas vão se multiplicando, aguçam a curiosidade a respeito das possíveis relações entre um enredo e os outros. Esse tipo de protelação serve para protelar a expectativa do leitor e o fechamento do enredo (Rodrigues, 2014, p.72).

Outra característica das narrativas são as perguntas sem resposta que surgem ao longo da narrativa: "são os links para os atos e as viradas das sequências" (p.75). Durante a fase do escândalo, muitas perguntas sem respostas surgem em Veja sobre a suposta participação de Dirceu até o depoimento de Renilda Souza e o envolvimento da ex-mulher dele Angela Saragoça em um empréstimo, como vimos no capítulo 3.

Por fim, a revista também se utiliza do enredo não linear para compor suas narrativas, também presente nos roteiros dos seriados de TV e do cinema. De acordo com Rodrigues (2014), as etapas da história são lineares, mas as etapas que vão ao ar podem ser apresentadas de forma linear ou não.

Estratégias Argumentativas - Também pretendemos identificar na pesquisa as estratégias argumentativas presentes nas narrativas e quais os jogos de linguagem usados pela revista Veja quando se refere a José Dirceu como personagem na narrativa da publicação. Vários elementos podem ser usados nas mensagens que caracterizam as intenções do narrador como figuras de linguagens e ironia.

No caso da narrativa jornalística, uma das intencionalidades propostas por Motta (2013) é o efeito de real que leva o narrador a recorrer à objetividade, uso de citações de fontes que tem autoridade ou conhecimento para falar de determinado tema, localização geográfica, dados estatísticos e a identificar os personagens.

Segundo Motta (2013), a narrativa é um dispositivo de argumentação e evidenciar pistas de efeito de real contribui para a constatação dos possíveis efeitos estéticos de sentido no receptor da mensagem. "As narrativas realistas utilizam uma linguagem referencial para vincular sempre os fatos ao mundo físico, mas criam efeitos catárticos, como na ficção" (p.196). Para ele, existe um jogo permanente entre intenções do narrador e as interpretações do receptor. "O narrador é, por natureza, discreto. Utiliza recursos de linguagem que procuram camuflar seu papel” (p. 197). 
A retórica do jornalismo, conforme Motta (2013), procura formas de aproximar o leitor da notícia ou dos episódios narrados, mesmo em editorias consideradas difíceis e duras como a de economia. Todas as narrativas fáticas são capazes de "dissimular os aspectos argumentativos" (p.198). Um dos objetivos dessa dissimulação é fazer crer que os fatos são evidentes para naturalizar o discurso narrativo.

Para isso, de acordo com Motta (2013), o jornalismo se utiliza de operações lingüísticas para "convencer o leitor de que o texto é uma representação fiel da verdade e da realidade" (p.201). São essas operações que precisam ser identificadas pelo analista de narrativas. Uma delas são as aspas dos entrevistados ou falas que são atribuídas a pessoas envolvidas na narrativa.

O efeito de sentido gerado pelas estratégias argumentativas do narrador ao receptor também norteou estudos de pesquisadores de várias áreas. Iser (1999), que realizou estudos sobre análise literária, expõe por meio de uma linha de pensamento denominada readerresponse-criticism suas suposições a respeito da experiência mental do receptor durante a leitura, por exemplo, que pode ser aplicado a textos jornalísticos mais bem elaborados como as grandes reportagens. Esses textos se utilizam elementos ficcionais como enredo, personagens e clímax.

De acordo com Iser (1999), o processo de negociação começa pelas lacunas e hiatos encontrados pelos leitores que vão construindo uma autonomia de interpretação e de sentido em relação ao texto.

Nenhuma história pode ser contada na íntegra (...)o padrão textual se revela um jogo, uma interação entre o que está expresso e o que não está.Isso se torna uma experiência para o leitor que o incorpora (o padrão textual) segundo sua própria compreensão e identifica como o sentido do texto. Desse modo, o significado do texto resulta de uma retomada ou apropriação daquela experiência que o texto desencadeou e que o leitor assimila e controla segundo suas próprias disposições (1999, ps.28 e 29).

No caso do jornalismo, a produção de conteúdo nas redações é caracterizada por elementos relacionados às preferências da audiência/leitores e aos interesses mercadológicos das empresas de comunicação. Estudos apresentados por McCombs (2004) apontam que os efeitos de sentidos gerados pelo agendamento e o enquadramento de determinados assuntos pelos veículos de comunicação influenciam no comportamento das pessoas após a ampla exposição de matérias. Ele exemplificou o clima de medo em 
moradores de uma localidade sendo uma das consequências quando há destaque para cobertura demasiada de um crime.

\begin{abstract}
O agendamento de atributos foca na habilidade da mídia em influenciar como nós capturamos os objetos. Os enquadramentos chamam nossa atenção para as perspectivas dominantes destas imagens que não somente sugerem o que é relevante e irrelevante, mas que, ativamente, provocam um problema particular, de definição, interpretação causal, avaliação moral e/ou recomendação de tratamento para o item descrito (McCombs, 2004, p.140).
\end{abstract}

Já Walter Benjamin incorpora o desenvolvimento dos veículos de comunicação, a impressão dos romances e o próprio jornalismo como parte da falência da narrativa oral que permitia maior liberdade de interpretação por parte do ouvinte e identificação com a experiência do narrador. Para ele, a narrativa jornalística retirou os elementos passíveis de interpretação por causa da busca pela objetividade. "Mas a informação aspira a uma verificação imediata, antes de mais nada, ela precisa ser compreensível em si e para si (p.203).

Ele constata que, mesmo que a cada manhã recebamos notícias de todo o mundo, elas são pobres em histórias surpreendentes por serem excessivamente explicativas. Benjamin afirma que a narrativa é deixada de lado a serviço da informação.

Metade da arte narrativa está em evitar explicações. O extraordinário e o miraculoso são narrados com a maior exatidão, mas o contexto psicológico da ação não é imposto ao leitor. Ele é livre para interpretar a história como quiser e com isso o episódio narrado atinge uma amplitude que não existe na informação (p.203).

Van Djik (1996), que estuda análise de discurso e da cognição, inclusive na estrutura das notícias, acredita que as experiências individuais influenciam no processo de compreensão das histórias e discursos.

O processamento do discurso como outros processos complexos de informação é um processo estratégico no qual uma representação mental, na memória, é construída a partir do discurso, usando informações externas e internas com o objetivo de interpretar (entender) o discurso (p.16).

$\mathrm{Na}$ visão do autor, a representação do discurso na memória depende da disponibilidade/interesse do ouvinte em saber o que será narrado, objetivos e intenções do narrador/locutor ao contar uma história e da motivação/atenção do ouvinte durante a narração. 
A manipulação dos receptores não está totalmente descartada nesses casos, principalmente, porque a mídia, além de objetivos mercadológicos, também tem interesses políticos e afinidades partidárias, por exemplo, que refletem a linha editorial do veículo. A própria estrutura dos jornais e do fazer jornalístico acentuam as estratégias eficientes do discurso manipulador, segundo Van Djik (2012). Ele explica que a manipulação é uma influência mental exercida pelo discurso por meio da informação, ensinamentos e persuasão, capaz de mudar ou modelar conhecimentos e opiniões a partir da Memória de Curto Prazo - MCP. Além de ser um meio de dominação e abuso de poder.

\begin{abstract}
Ao imprimir parte do texto em fontes grandes ou em negrito, esses dispositivos atrairão mais atenção e serão processados com recursos extras de tempo e memória, como é o caso das manchetes, títulos ou slongansque também funcionam como categoria convencional do texto para a expressão das macroestruturas semânticas ou tópicos que organizam as estruturas semânticas locais e afetam o gerenciamento da compreensão estratégica da MCP (p.241).
\end{abstract}

Já em relação ao jornalismo, Van Djik (2012) aponta que as estratégias de manipulação ficam ainda mais evidentes da cobertura política. É importante lembrar que as estratégias da MCP nos meios eletrônicos são ainda mais acentuadas por causa do estilo mais simples e direto nas matérias.

"Se os meios de comunicação de massa fornecem informações incompletas ou, por outro lado, tendenciosas, sobre um político específico durante uma campanha eleitoral com o propósito de influenciar os votos dos eleitores, poderíamos ter um caso de manipulação", aponta Van Dijk (2012, p.239). O autor afirma que há vários estudos cognitivos gerais de processamento de discurso, realizados por ele e outros autores, que comprovam a influência da manipulação contextual ou textual na compreensão de determinados assuntos.

Van Djik (2012) completa que "isso não significa que um jornal não poderia apoiar ou favorecer seu próprio candidato, mas isso deveria ser feito com argumentos, fatos, ou seja, através da informação adequada e da persuasão" (p.239).

Os fundamentos de Van Djik a respeito da relação entre o emissor e o receptor no processamento dos discursos apontam para uma das constatações de Motta (2013) quando a análise do jornalismo é feita sob a ótica da narrativa: existe um contrato cognitivo entre jornalista-narrador e o leitor/espectador que envolve principalmente a credibilidade e a objetividade. Para Motta, as narrativas jornalísticas produzem efeito de real a partir da organização discursiva de veridicção. 
O leitor ou ouvinte entra nessa relação com um tipo semelhante de intenção e desejo: ele quer saber a verdade e acredita, por razão de autoridade e hierarquia que seu interlocutor tem legitimidade para discernir a verdade, e confia que ele vai lhe contar a verdade, estabelecendo-se um contrato comunicativo e cognitivo para a instituição da realidade objetiva (p.39).

Nesses casos, também é mais difícil identificar a negociação de sentido com o destinatário do narrador, segundo Motta (2013), quando se trata da representação de jogos de poder e correlação de forças - muito presentes em narrativas jornalísticas sobre política no Brasil.

Os conflitos políticos inseridos nos escândalos político-midiáticos compõem uma série de estratégias enunciativas usadas pela mídia e, consequentemente por Veja, para espetacularizar os fatos por meio de recursos dramáticos, com o objetivo de construir realidades e convencer o destinatário de que a informação é verdadeira.

\footnotetext{
A enunciação narrativa é uma atitude intencional e argumentativa, portanto: toda narrativa se origina em uma estratégia enunciativa. Ao tomar a decisão de contar uma história alguém tem em mente uma intencionalidade. Ninguém conta uma história ingenuamente. (MOTTA, 2013, p.38)
}

Pode-se dizer que uma das estratégias argumentativas da revista é algo presente no agendamento da cobertura política no Brasil: priorizar os escândalos e denúncias nas matérias e reportagens, além de reforçar a constate desconfiança na política e nos políticos. Nos últimos 10 anos, o embate ideológico de Veja com o Partido dos Trabalhadores - PT, que governa o país desde 2003, contribui decisivamente para o pacto cognitivo com os seus leitores e com outros veículos de comunicação que repercutem suas reportagens.

Dessa forma, a repercussão dos assuntos influencia decisões de governo, de parlamentares, além de pautar eventuais demandas da opinião pública. O caso de José Dirceu é emblemático: a pressão externa exercida pela mídia e outras organizações culminou em sua demissão da Casa Civil e cassação no Congresso em 2005 após o escândalo do Mensalão.

\section{2 - Aspectos Metodológicos}

Foram analisadas doze matérias em dez edições da revista Veja entre os anos de 2005 e 2014, em que José Dirceu está presente na capa, com o objetivo de investigar quais as funções que são atribuídas a ele como personagem da narrativa da publicação. Esse, porém, não é o universo completo de matérias sobre Dirceu na Veja. O recorte foi 
escolhido a partir do escândalo do Mensalão por ser um ponto de virada de total transformação na trajetória do personagem na narrativa da revista. Ele não havia sido apontado como articulador de esquema de corrupção até o momento e sido destaque de capa na publicação por isso.

Como já mencionamos na Introdução, a metodologia de análise se baseou em vários elementos presentes na Análise Crítica da Narrativa, preconizada por Motta (2013), da análise estrutural da narrativa, presente em Todorov (1971), Gancho (2002) e Abdala Junior (1995) e pela identificação nas matérias de características presentes nos roteiros das séries de TV e do cinema por meio dos estudos de Rodrigues (2014) e Vogler (2006).

Abaixo, listamos no Quadro 3 as principais funções já observadas de personagens que estão relacionados com a narrativa sobre José Dirceu na Veja.

\section{Quadro 3}

\begin{tabular}{|c|c|c|}
\hline Personagens & Descrição & $\begin{array}{c}\text { Ações atribuídas pela cobertura da } \\
\text { Veja }\end{array}$ \\
\hline José Dirceu & Ex-ministro Chefe da Casa Civil & Mentor do esquema \\
\hline Roberto Jefferson & Ex-deputado federal (PTB/RJ) & Delator do esquema \\
\hline Lula & Ex-presidente da República & Não foi comprovada sua culpabilidade \\
\hline José Genoíno & $\begin{array}{l}\text { Ex-deputado federal (PT/SP) e ex-presidente } \\
\text { do PT }\end{array}$ & $\begin{array}{l}\text { Um dos articuladores das alianças do } \\
\text { governo }\end{array}$ \\
\hline João Paulo Cunha & Ex-presidente da Câmara dos Deputados & Recebeu dinheiro do Mensalão \\
\hline Delúbio Soares & Ex-tesoureiro do PT & $\begin{array}{l}\text { Administrar e distribuir o dinheiro } \\
\text { arrecadado }\end{array}$ \\
\hline Marcos Valério & Publicitário e empresário & $\begin{array}{l}\text { Arrecadar o dinheiro de caixa } 2 \text { para o } \\
\text { PT }\end{array}$ \\
\hline Renilda Fernandes & Esposa de Marcos Valério & $\begin{array}{l}\text { Disse ter visto Dirceu em reuniões com } \\
\text { o marido }\end{array}$ \\
\hline Silvio Pereira & Ex-secretário do PT & $\begin{array}{l}\text { Um dos articuladores das alianças do } \\
\text { governo }\end{array}$ \\
\hline Duda Mendonça & Publicitário da campanha de Lula em 2002 & $\begin{array}{l}\text { Disse ter recebido do PT mais } \mathrm{R} \$ 11 \mathrm{mi} \\
\text { de caixa } 2\end{array}$ \\
\hline $\begin{array}{l}\text { Antonio Fernando } \\
\text { de Souza }\end{array}$ & Procurador-Geral da República em 2005 & $\begin{array}{l}\text { Autor da acusação do MPF referente ao } \\
\text { Mensalão }\end{array}$ \\
\hline Delcídio Amaral & Ex-senador e presidente da CPI dos Correios & $\begin{array}{l}\text { Conduziu as investigações da CPI } \\
\text { mesmo sendo do PT }\end{array}$ \\
\hline Roberto Marques & Assessor de José Dirceu & $\begin{array}{l}\text { Saque de R\$ } 50 \text { mil do dinheiro do } \\
\text { Mensalão }\end{array}$ \\
\hline $\begin{array}{l}\text { Waldemar Costa } \\
\text { Neto }\end{array}$ & Ex-deputado federal e líder do PR & $\begin{array}{l}\text { Líder partidário que recebeu dinheiro do } \\
\text { Mensalão }\end{array}$ \\
\hline Joaquim Barbosa & Ex-presidente do STF e relator da AP-470 & $\begin{array}{l}\text { Combatente da corrupção e da } \\
\text { impunidade }\end{array}$ \\
\hline
\end{tabular}




\begin{tabular}{|l|l|l}
\hline $\begin{array}{l}\text { Ricardo } \\
\text { Lewandovisk }\end{array}$ & Ministro do STF e revisor da AP-470 & $\begin{array}{l}\text { Protetor dos réus do núcleo político do } \\
\text { PT }\end{array}$ \\
\hline Roberto Gurgel & Procurador-Geral da República em 2012 & $\begin{array}{l}\text { Combatente da corrupção e da } \\
\text { impunidade }\end{array}$ \\
\hline Clara Becker & $\begin{array}{l}\text { Ex-mulher de Dirceu durante a } \\
\text { clandestinidade }\end{array}$ & $\begin{array}{l}\text { Enganada por Dirceu, foi uma de suas } \\
\text { vítimas }\end{array}$ \\
\hline Otávio Cabral & Jornalista & $\begin{array}{l}\text { Responsável por revelar a verdade sobre } \\
\text { Dirceu }\end{array}$ \\
\hline
\end{tabular}

A escolha desses personagens obedeceu a critérios qualitativos, de acordo com as observações e leituras das doze matérias escolhidas. O principal critério foi o grau de relação desses personagens com o protagonista José Dirceu. Todos os personagens descritos acima se relacionaram, nas páginas de Veja, com a narrativa do protagonista nas três fases que englobam o escândalo, o julgamento e a prisão do ex-ministro.

As funções de personagens podem ser identificadas principalmente por meio das descrições psicológicas, morais e sociais propostas por Gancho (2002). As características físicas são consideradas, caso estejam relacionadas com alguma decisão ou atitude do personagem, isso também se enquadra ao espaço físico ou o ambiente.

No escândalo do Mensalão, observamos que cada um dos personagens exerce um papel diferente em várias situações relacionadas ao esquema. Em nosso campo de análise, serão considerados os personagens que estão no quadro 1 por terem tido mais visibilidade ao longo de todo o caso, desde a sua eclosão até o julgamento dos acusados. Todos eles estão relacionados a José Dirceu. Como exemplo, podemos citar a mulher de Marcos Valério, Renilda Souza, que não teve destaque constante ao longo da cobertura, como aconteceu com o marido, mas causou impacto para a trajetória de José Dirceu por ter revelado a CPI dos Correios que o ex-ministro se encontrava com Valério para tratar dos empréstimos (ver capítulo 3).

Outro exemplo é Clara Becker, que não está envolvida diretamente ao escândalo, mas volta à tona sempre que Veja faz questionamentos morais a Dirceu. Clara, que se uniu ao ex-ministro sem saber que ele havia assumido outra identidade, representa, para a Veja, o papel de uma das vítimas de Dirceu porque, como foi observado em análises preliminares, desde a Ditadura Militar, a revista procura motivos ou situações para confirmar que ele seria "capaz de tudo" para conseguir o que quer na política, mesmo a situação com Clara sendo de cunho pessoal. 
O jornalista Otávio Cabral, autor de algumas das matérias que constam entre as edições estudadas, é considerado pelo estudo como narrador-personagem. Isso acontece porque ao lançar o livro "Dirceu - A Biografia"11, Cabral assume a condição de antagonista a Dirceu, na matéria publicada na edição 2325, de 12 de junho de 2013, que simboliza o repórter vigilante, que fiscaliza os políticos e, dessa forma, combate a corrupção. A matéria evidencia que Cabral seria um dos responsáveis em desvendar o que José Dirceu esconde.

Abaixo, listamos as etapas metodológicas da pesquisa, algumas delas já executadas na elaboração deste projeto que será submetido a exame de qualificação.

\subsection{1 - Metodologia}

A metodologia da pesquisa foi organizada de acordo com os problemas e objetivos do trabalho, conteúdo das reportagens e a cronologia que seguem após leitura aprofundada com vistas para a interpretação dos textos.

A análise individual das matérias selecionadas é orientada pela ótica da narrativa do escândalo político-midiático como acontecimento-intriga e o ciclo vivido pelo personagem nas páginas da Veja. Portanto, se concentra nos episódios, sequências cronológicas das ações, enredo, intriga, conflito, cenários, papéis e funções dos personagens e seus pontos de virada.

Este ciclo, chamado no trabalho de "ciclo político-midiático" é baseado no "Ciclo do Herói" proposto por Campbell (1997) e na "Teoria do Escândalo" de Thompson (2002). O ponto de partida para a análise da função do personagem das narrativas é o estudo de Propp (2001) sendo também considerados outros autores.

Por meio da interpretação das 12 matérias, foi possível traçar como este ciclo político midiático caracteriza as funções que José Dirceu exerce no encadeamento das narrativas noticiosas selecionadas: formação até se tornar político, momento em que alcança poder, escândalo, questionamento de reputação, pressão da opinião pública, punição imediata (perda de cargos e mandato) e ostracismo.

\footnotetext{
${ }^{11}$ O livro de Otávio Cabral é considerado polêmico e inclui informações não confirmadas. Porém, foi utilizado como fonte por ser uma biografia de José Dirceu que reúne informações de maior parte do período de 2005 a 2013, que não está presente no livro "Abaixo a Ditadura" (Dirceu e Palmeira, 1998) e em "O Sapo e o Príncipe" (Markun, 2004) que trazem referências históricas sobre Dirceu.
} 
Com os dados apurados e a relação entre as matérias analisadas, foi possível direcionar a conclusão da pesquisa. $\mathrm{O}$ estudo observou de que forma o enunciado narrativo sobre José Dirceu foi construído por Veja no papel de narrador, recursos estratégicos para destacar certas características do personagem e de seus antagonistas e quais são, se foram elaborados efeitos dramáticos de sentido por meio dos recursos de linguagem utilizadas pela revista (estratégias argumentativas) que evidenciaram e, finalmente, quais intencionalidades do discurso realizado pelo narrador foram reveladas pela interpretação das narrativas.

Passamos agora para o capítulo 5, onde nos concentraremos nas análises das doze matérias sobre José Dirceu de 2005 a 2014 presentes em dez edições de Veja em que o personagem tem destaque de capa na publicação. 


\section{CAPÍTULO V}

\section{ANÁLISE DA NARRATIVA DA REVISTA VEJA SOBRE O PERSONAGEM JOSÉ DIRCEU DURANTE E APÓS O ESCÂNDALO DO MENSALÃO}

Segundo categorias presentes nas metodologias apresentadas no capítulo teóricometodológico, as doze matérias foram analisadas a partir dos seguintes itens: capa, foto principal, recursos gráficos, narrativa/tempo, espaço predominante, ambiente, narrador principal e as funções dos personagens com destaque para José Dirceu.

\section{1) Edição 1910 - 22 de junho de 2005}

Capa: Tem conserto?

Com a demissão de José Dirceu Lula tenta salvar o governo e sua biografia

Chamada: Nocaute - Cinquenta horas depois de Roberto Jefferson, o homem a quem o governo fez tudo para desqualificar ter dito "rápido, sai daí rápido Zé", José Dirceu deixa a Casa Civil

Resumo: reportagem conta os bastidores da saída de José Dirceu da Casa Civil em função das primeiras denúncias do mensalão, a influência de Roberto Jefferson nesse processo, a relação de Lula e Dirceu que segundo a revista é marcada por discordâncias e como o presidente estaria reagindo ao momento mais difícil de seu governo até o momento por José Dirceu ter articulado as principais alianças partidárias.

\section{Análise:}

Capa: céu que representa um cenário nebuloso com uma estátua de Lula que está prestes a desmoronar. A imagem reforça a ideia da revista de que o então presidente era um político forte que, naquele momento, estaria sofrendo abalos em sua trajetória e estrutura de governo. A dúvida apontada pela revista é se as "rachaduras" teriam conserto com a demissão de Dirceu.

Foto principal: mostra Dirceu ao lado de Lula com um jogo de luz e sombras. O presidente fazia um movimento com a mão. Mas a sombra por trás remete que Lula estaria prestes a dar um soco no ex-ministro. A imagem justifica a chamada principal da matéria "Nocaute". É importante observar aqui a intencionalidade da revista em mostrar que a política possui um lado conhecido e outro desconhecido (que seria a sombra). O lado conhecido seria a proximidade entre Lula e Dirceu e o lado sombrio seria uma espécie de competição entre os dois, vencida pelo ex-presidente, que demitiu seu ministro em meio a acusações em um escândalo político. O distanciamento de aliados é destacado por Thompson (2002) em situações desse tipo.

Recursos gráficos: Dois boxes cronológicos. Um na parte de cima sobre a ascensão e queda de Dirceu no primeiro mandato do governo Lula. O outro destaca que Roberto Jefferson confirmou as denúncias publicadas em matérias anteriores da revista sobre corrupção no PTB que evidencia a cobertura adversária e que os veículos midiáticos buscam a credibilidade no contexto dos 
escândalos (Guazina, 2011).

\section{Narrativa:}

O acontecimento-intriga é o escândalo do Mensalão, mas o núcleo narrativo da matéria é a demissão de José Dirceu do cargo de ministro da Casa Civil. Outros episódios relacionados ao escândalo também são relatados como os depoimentos de Roberto Jefferson em Comissões Parlamentares com destaque quando se refere a Lula e a Dirceu e denúncias de corrupção no PTB feitas pela Veja em anos anteriores.

O enredo é não-linear. A matéria é de repercussão de um fato já ocorrido, porém amplia o assunto com informações oriundas de bastidores (confirma que Veja mescla os estilos hard e soft news) inclusive com a descrição de situações que teriam ocorrido antes da eclosão do caso. É marcado por encadeamento de fatos (faz uma cronologia da trajetória de José Dirceu no governo até a sua demissão) e também por encaixamento dos outros episódios citados acima.

Tempo: não-cronológico. Mistura fatos de um passado recente e os mostra como indícios do mensalão (2003), do que estaria acontecendo no presente (2005), faz previsões futuras, além de resgate histórico sobre as trajetórias e origens políticas de Lula (década de 70) e Dirceu (década de $60)$.

Espaço predominante: Brasília, Congresso Nacional e Palácio do Planalto.

Ambiente: hostilidade entre adversários políticos, traição de ideais, ambição e ganância por dinheiro ilícito e poder.

Narrador principal: é o jornalista de Veja, autor da matéria, Otávio Cabral. É onisciente e intruso. Também descola para as fontes, entrevistados e falas públicas a narração de alguns fatos.

\section{Personagens principais da matéria:}

A função de Dirceu é de protagonista, porém "fracassado". Para a revista, ele teria realizado ações decisivas para construção do acontecimento-intriga e é o centro das atenções no núcleo narrativo.

Na matéria, Veja destaca a glória e o fracasso de José Dirceu, no espaço de tempo entre o início do governo e sua demissão da Casa Civil. Mas a publicação tenta ampliar, de forma irônica, essa percepção ao acrescentar que o fracasso do ex-ministro não foi algo relacionado exclusivamente ao governo Lula e ao escândalo e, sim, a toda sua história de militante de esquerda. Ou seja, ele passou a fazer parte do conjunto de estereótipos do político comum.

\section{Trechos em destaque:}

“(...) (Dirceu) fez de seu notável triunfo político (a chegada do PT ao poder) um emocionado tributo ao que tombaram na luta contra a opressão” (pg.47).

Em seguida, a revista volta ao presente para contrastar as concepções ideológicas da realidade vivida pelo ex-ministro. O narrador principal utiliza a expressão popular "flagrado com a boca na botija" (pg.47) quando se refere à situação atual de José Dirceu e ironiza a forma como o exministro se defendeu. 
“(...) saiu do Palácio do Planalto pela porta dos fundos sob o peso de acusação de ter comandado o mensalão (...). No discurso de despedida, ecoando o lamentável estilo dos políticos ortodoxos flagrados com a boca na botija, José Dirceu disse que saía de 'mãos limpas'e 'cabeça erguida'," (pg.47).

A liderança e influência de Dirceu no primeiro governo Lula e no PT são os elementos cruciais na caracterização social do personagem, como forma de justificar os atos para os quais estava sendo acusado, principalmente por Roberto Jefferson. Os atos seriam fruto de um pragmatismo político que se utiliza de corrupção e pagamento de dinheiro ilícito a terceiros para se manter no poder.

"Sobre Dirceu (Jefferson) contou que o ministro reclamara que o PT estava na penúria porque a Polícia Federal 'meio tucana' prendera dezenas de doleiros e 'a turma que ajuda não está podendo internar dinheiro no Brasil'," (pg.48).

As alusões de crime organizado ao PT estão presentes na frase acima com as expressões "penúria", ou seja, o partido estaria em dificuldades financeiras ou de conseguir o dinheiro para manter o esquema; e a "turma que ajuda" que levam a revista mais adiante a afirmar, por meio de entrevistados, que a suposta relação entre PT, partidos aliados e com o auxílio de terceiros se assemelhava a máfia. Portanto, diante da caracterização feita pela revista de que Dirceu havia se tornado o principal articulador e líder petista, Veja leva o leitor a concluir que o ex-ministro seria uma espécie de "Poderoso Chefão", conforme exemplos abaixo.

“'O Dirceu foi a pessoa mais importante do governo', diz o líder do PT no Senado, Delcídio Amaral, escalado para o delicado cargo de presidente da CPI dos Correios. 'Ele não tinha crise de consciência, segurava o PT, mostrava claramente o ônus e o bônus de ser governo'”' (pgs. 49 e 50).

“'José Dirceu acabou vítima de si próprio', analisa o filósofo Roberto Romano, professor de ética política da Universidade Estadual de Campinas. 'Procurou Roberto Jefferson que jamais cairia no colo de um governo petista e acabou destruído por ele. Era uma aliança nos moldes da máfia, que não tinha como acabar bem,'” (p.49).

A ideia desse tipo de caracterização do personagem José Dirceu também é reforçada pelo resgate do passado recente. No anterior, 2004, a revista "Época" publicou matéria com uma gravação em que um dos principais assessores de Dirceu, Waldomiro Diniz, estaria pedindo dinheiro de propina durante as eleições de 2002 do PT para o governo do Rio de Janeiro. Na época das denúncias, o exassessor pediu demissão do que cargo que exercia na Casa Civil. É possível observar a caracterização no exemplo abaixo:

"Na Casa Civil, a turma de Dirceu ficou conhecida como o 'pedaço mais contaminado do governo'. Agora (após o escândalo envolvendo Waldomiro Diniz) cai o próprio José Dirceu também com água até o pescoço em um mar de suspeitas" (p.49).

A função de Roberto Jefferson, até aquele momento, era a de antagonista de José Dirceu, mas também de um delator que participou de um esquema de corrupção. A matéria remete, em várias passagens, ao fato de que Jefferson não é inocente por denunciar, principalmente quando se refere a denúncias de corrupção no PTB publicadas pela revista e negadas por ele mas que, após o mensalão vir à tona, foram confirmadas pelo próprio . Isso demonstra que Veja, apesar de considerar a importância do deputado petebista para as evidências sobre o escândalo do mensalão, 
com informações e até diálogos detalhados, quer manter sua oposição à corrupção política e o seu papel de defensora do interesse público, ainda mais em um caso que envolve o PT, seu adversário político-ideológico.

Os trechos abaixo exemplificam os aspectos que mencionamos:

"Numa das várias tentativas de purificar-se, banhando-se na própria lama, Jefferson contou que a bancada do seu honrado PTB chegou a votar - votar! - se queria ou não receber o mensalão de 30 mil reais" (p.48).

"Jefferson procurou comporta-se como se fosse um, digamos, gigante da baixa política: confessou crimes que ele próprio cometeu, desmentiu mentiras que ele próprio contara antes de distribuiu acusações aberta a cinco ministros e sete deputados". (p.47)

Portanto, não há intenção prioritária em inocentar Jefferson, sua posição como personagem no escândalo é, inclusive, ironizada. A diferença está na forma em que a publicação destaca as falas do líder do PTB em seus depoimentos, principalmente quando relacionadas ao presidente Lula e a Dirceu. Na visão de Veja, a influência do líder do PTB nos episódios que levaram à demissão é, de certa forma, humilhante para um político como José Dirceu, um homem poderoso, quase intocável pelo nível de confiança que teria com Lula. Por isso, Jefferson é chamado de "gigante da baixa política" pela revista para reiterar o fracasso de Dirceu. O trecho abaixo exemplifica este aspecto em Veja:

"O anúncio da demissão do ministro foi ainda precedido por uma cena melancólica. Ao depor no processo de cassação do seu mandato Jefferson pediu a demissão de Dirceu. 'Zé Dirceu, se você não sair dai rápido, você vai fazer réu um homem inocente que é o presidente Lula'. E olhando para a câmera de televisão, aduziu: 'rápido. Sai dai rápido, Zé”. Cinqüenta horas depois disso, o que aconteceu? O Zé saiu” (p.47).

A demarcação de antagonismo entre Jefferson e Dirceu fica evidente quando a revista afirma que, após saber da demissão de Dirceu, o petebista deu uma gargalhada. Outra significação possível é de contraste entre a melancolia da queda de Dirceu em relação à alegria irônica e sarcástica de Jefferson, que poderia estar se sentindo vingado. As passagens em que são destacadas as falas de Jefferson são carregadas de dramaticidade, diálogos entre personagens da matéria, um estilo de retórica do próprio deputado aproveitado pelos veículos de comunicação, principalmente os canais de televisão.

Já a função do então presidente Lula seria de uma possível vítima, "um homem inocente", segundo Jefferson (p.47). A matéria afirma que, até aquele momento, não havia provas da existência do mensalão, nem da participação de Lula. Mas os indícios de supostos esquemas de corrupção na base aliada, relatados pelo líder do PTB e por outras fontes, ajudam a revista construir sua narrativa para convencer o leitor de que existe corrupção no governo do PT e isso é condenável moralmente. Então, a caracterização de Lula é baseada nos depoimentos de Jefferson e nas informações que a revista afirma terem sido repassadas por interlocutores não identificados do presidente.

A inocência e sentimento de traição por parte de Lula é outro contraste exposto pela revista sobre a possível atuação de José Dirceu no PT e, posteriormente, no governo. Agindo nas sombras como propõe a foto principal da matéria, Dirceu teria feito coisas que o presidente não teve conhecimento. 
Durante a crise, Lula não teve alternativa a não ser demitir Dirceu, mas sentiria falta de seu articulador. Então, constata-se a intenção da revista de mostrar que o poder do ex-ministro era tanto que fazia de Lula seu dependente, conforme pode se verificar a seguir:

"Lula manifestou certa perplexidade na semana passada. 'E agora como é que fica o meu governo' comentou com interlocutores próximos. Lula está decidido a recolocar seu governo nos trilhos (...) quer recuperar sua autoridade” (p.51).

O poder de decisão de Lula como presidente da República antes da demissão de Dirceu é questionado por Veja. É como se finalmente ele fosse conseguir governar com certa autonomia. Semelhante a Jefferson, a revista utiliza supostas falas de Lula (repassada pelos interlocutores) com teor dramático, demonstrando a fragilidade do presidente em relação à crise trazida ao governo pelo escândalo do mensalão. As próximas decisões de Lula são relatadas como incertas. É possível conferir este tratamento da revista ao ex-presidente no trecho abaixo:

"Em pleno choque de perder um auxiliar como Dirceu, Lula voltou a ameaçar desistir da reeleição. 'Eu não sou Collor, não sou Fernando Henrique. Não vou sujar minha biografia por causa de uma reeleição'”' (p.51).

Para Veja, Lula também se contradiz em seus atos públicos em relação aos depoimentos que a matéria teve acesso, inclusive em questões administrativas, conforme se observa a seguir:

"(Lula) disse que estava indignado com as denúncias (...) e que não sobrará pedra sobre pedra. Mas dois dos sete diretores afastados do comando dos Correios sob denúncias de corrupção foram contratados como consultores da nova diretoria sem que se tenha colhido um único indício de que ambos sejam inocentes" (p. 51 e 52).

\section{Personagens secundários:}

Elencamos, a seguir, as principais personagens que completaram as narrativas de Veja nesta edição em análise.

- José Genoíno, Silvio Pereira e Delúbio Soares (o núcleo político do PT, que teria articulado as alianças e o pagamento aos partidos da base aliada do governo).

- Marcos Valério (acusado de ser o operador do esquema) é citado apenas uma vez. Há uma matéria maior sobre ele em seguida.

- Delcídio Amaral (presidente da CPMI dos Correios) foi entrevistado para repercutir a saída de Dirceu. Ele disse à revista que o ex-ministro era a pessoa mais importante do governo.

- Deputados demitidos por Sandro Mabel (não identificados) porque, de acordo com a revista, a fonte de dinheiro para mantê-los no cargo teria acabado.

- Ex-tesoureiro do PP Benedito Domingos (aspas dadas ao estadão, ele foi entrevistado).

- Três deputados do PSDB que votaram com o governo foram ameaçados de expulsão e recorreram a Dirceu. Segundo Veja, a história foi confirmada por três líderes tucanos. Só José Aníbal é identificado, mas não é citado se o próprio confirma as informações. 
- Antonio Palocci (ministro da fazenda): Veja afirma que a política econômica era satisfatória e que Dirceu tentava intervir sem sucesso. Em sua pesquisa, Guazina (2011) destacou que a satisfação com a política econômica do governo acabou protegendo Palocci de eventuais ataques durante a cobertura do escândalo do Mensalão no Jornal Nacional.

\section{Considerações sobre a matéria em análise:}

- A revista não entrevistou José Dirceu para a reportagem e também não informa se tentou e não conseguiu. Apenas cita que o ex-ministro alega inocência, porém, a diz de forma irônica.

- As frases mais fortes da matéria relacionadas a José Dirceu são de Jefferson e Lula. As falas de Jefferson são as que foram registradas publicamente em seus depoimentos. As de Lula teriam sido repassadas por interlocutores.

- O narrador utiliza recursos de linguagem como a ironia, o sarcasmo e ditos populares quando se refere aos personagens principais. Há um foco dramático sobre Lula que estaria sofrendo os abalos da crise. Por isso, as falas do então presidente são carregadas de tensão, dúvidas e incertezas.

- Há também a intenção de comparar Dirceu a Lula, suas biografias e origens. Para Veja, Lula é "um homem das massas" (pg.53) oriundo do Movimento Sindical na década de 70 e ia continuar sendo e Dirceu, que começou no Movimento Estudantil na década de 60, se tornou um político de bastidores. Há também o destaque para a incerteza se Lula e Dirceu são realmente amigos ou se a relação é apenas política (isso também é observado em outras matérias analisadas).

Para dizer isso, a revista utiliza a informação de que José Dirceu estava perdendo espaço para Palocci e Luiz Gushiken (ministro da Secretaria de Comunicação Social) entre os conselheiros de Lula "a saída de José Dirceu não provocará alterações significativas" (pg.53).

- Para Veja, a "imagem imaculada" (p.53) de Lula sofreu um estrago e pergunta se tem conserto, como na capa.

\section{2) Edição 1911 - 29 de junho de 2005}

Capa: ilustração do brasão da República com a estrela do PT e abaixo escrito "República Federativa do Zé”. Manchete: O grande erro - confundir o partido com o governo

Chamada matéria 1: $\mathrm{O}$ assalto ao estado - $\mathrm{O}$ mensalão destrói a imagem ética do PT mas o problema do país está na ocupação predatória do governo por petistas e aliados.

Resumo: A matéria faz uma relação de situações em que o PT estaria se apropriando da estrutura do Estado para beneficiar o partido e seus integrantes da cúpula, um deles José Dirceu. Um dos exemplos é a estrela do PT desenhada na grama do jardim do Palácio da Alvorada. Também faz uma retrospectiva do caso do Mensalão.

\section{Análise:}

Capa: a ilustração é simbólica sobre o que Veja considera como o erro do PT em "confundir partido com o governo". O mais interessante para a pesquisa são os dizeres "República Federativa do Zé", logo abaixo do brasão. A matéria principal da edição não é centralizada na figura de José Dirceu mas a revista faz essa referência. Há a possibilidade também de interpretação dúbia. Na 
linguagem popular o nome Zé pode significar "qualquer um". A exemplo de expressões como "Zé Ninguém". Com base na análise da edição anterior, a partir do Mensalão e da demissão de José Dirceu, Veja começa a construir uma narrativa em torno do ex-ministro o caracterizando como fracassado.

Foto principal: militantes do PT nas galerias da Câmara para recepcionar José Dirceu que, após a demissão da Casa Civil, iria reassumir seu mandato de deputado federal. Para Veja, as pessoas não estavam lá de livre e espontânea vontade, teriam sido convocadas pelo ex-ministro, seria uma "claque" como diz o jargão político para representar o público que só aplaude, sem identificação ideológica, por algo em troca.

Recursos gráficos: boxes na parte inferior das páginas da matéria principal com números a respeito da popularidade de Lula e uma enquete com eleitores do então presidente e de José Serra (candidato a presidente pelo PSDB em 2002) sobre o combate à corrupção e punição dos que a cometem.

\section{Narrativa}

O acontecimento-intriga continua sendo o escândalo do Mensalão. Porém o núcleo narrativo é composto pelo o que a revista considera como corrupção no governo do PT, suas alianças e loteamento de cargos para partidos aliados. Da mesma forma como na matéria da edição anterior, não há um fato novo que reforce a narrativa sobre o escândalo. A revista repercute assuntos já noticiados e afirmações nos depoimentos, mas dá detalhes do que o então presidente Lula estaria fazendo para fortalecer sua base aliada: dar mais espaço no governo para o PMDB que, na época, era o partido com o maior número de parlamentares e prefeitos do Brasil. A narrativa da revista gira em torno de erros administrativos que o PT deveria corrigir após as denúncias do Mensalão: distribuir cargos para partidos, que originou do escândalo, seria um deles.

Tempo: o tempo é não cronológico. A matéria já começa dizendo que o presidente Lula está a seis semanas enfrentando a crise causada pelo escândalo do Mensalão. A revista faz projeções sobre os objetivos do PMDB na aliança com o PT, por exemplo, e se baseia no passado recente para reforçar as evidências de que o mensalão existiu. Estes aspectos podem ser observados nos dois trechos a seguir.

"A cúpula do PMDB agora faz jogo duro para consumar o matrimônio com o governo (...) exige que o casamento não represente compromisso em apoiar Lula no ano que vem” (p.59).

"As acusações contra o PT no que diz respeito à compra de apoio do PTB por $R \$ 20$ milhões no ano passado estão acompanhadas dos detalhes mais criveis" (p.62).

Espaços predominantes: Câmara dos Deputados (onde estavam ocorrendo os depoimentos em Comissões), Palácio do Planalto (onde Lula estaria recebendo possíveis aliados), Palácio da Alvorada (onde foram plantadas flores vermelhas em forma de estrela no jardim) e casa de José Janene (onde o mensalão teria sido distribuído).

Ambiente: é de incertezas (sobre as reações do governo diante da crise), pressão (esta sofrida por Lula principalmente) conflitos políticos e acusações.

Narrador principal: É o jornalista Otávio Cabral, que assina a matéria. Ele é onisciente e intruso, 
pois emite juízos de valor sobre os partidos e políticos envolvidos no escândalo do Mensalão. O narrador acusa o PT de promover a "ocupação predatória do Estado" (p.59) e afirma que isso se trata de um "pecado capital" (p.59) e um "assalto ao Estado" (pg.59).

\section{Personagens}

Percebe-se que há uma pulverização dos personagens e não a centralização em um ou mais. O que o texto sugere é a interligação desses personagens na construção narrativa do que seria o escândalo do Mensalão. O PT pode ser considerado como protagonista da ação, pois é mostrado como responsável por todos os problemas que envolvem a distribuição de cargos no Poder Executivo.

\section{Personagens principais}

Lula: é descrito como alguém "meio perdido", tentando lidar com a crise mesmo sem a presença de José Dirceu. O Mensalão já não seria mais uma incógnita. Ele está precisando de apoio no Congresso. O maior desafio seria se fortalecer para as eleições de 2006. Para a revista, isso seria mais urgente, na visão do presidente, do que corrigir, de forma mais profunda, as origens da corrupção. Tais características podem ser observadas nos exemplos a seguir.

"O presidente Lula está perdendo uma oportunidade histórica de reformar antigos hábitos da política nacional” (p.60)

"Já aparecem fartos sinais de que o Mensalão pode ter mesmo existido no Congresso Nacional". (p.60)

José Dirceu: "Homem forte do governo no preenchimento dos cargos e no arranjo da base parlamentar" (p.63)

Fica o indício de que José Dirceu teria provocado situações que levaram ao Mensalão e que Lula estaria tentando reverter para fortalecer o governo. Porém, a revista condena os métodos baseados em coalisões partidárias e distribuição de cargos.

Ao longo da matéria até a página 63, Veja não cita José Dirceu. De forma crítica, enumera o que considera como erros do PT até citar o comportamento do ex-ministro entre eles. Nesse caso, podemos afirmar que a função de José Dirceu na matéria é o de mentor das ações dos personagens secundários que compõem o enredo em torno do escândalo do Mensalão.

Por exemplo, digamos que o enredo de uma trama policial apresenta uma sequência de fatos que levam a um crime maior. Porém, o mentor desse crime não aparece até a conclusão da narrativa, quando os indícios de sua realização se encaixam e fazem sentido. O destaque das características psicológicas e sociais de Dirceu, enumeradas pela revista, é outra maneira de reforçar ao leitor os motivos de um suposto esquema de corrupção do PT, conforme o exemplo abaixo.

"As suspeitas em torno de Dirceu decorrem também de sua concepção leninista de poder no qual o partido está acima do Estado" (p.63).

Para Veja, Dirceu, ao voltar para a Câmara, tenta deslocar sua crise para o resgate do que seria o seu heroísmo como militante de esquerda, que ocupou o poder, mas manteve suas origens. Porém, o narrador desqualifica esses atributos e alerta que o destino do personagem já estaria traçado, como se pode observar no trecho a seguir. 
"Dirceu, de volta a condição de deputado, quase tocou fogo na Câmara ao levar uma claque às galerias para saudá-lo como se seu regresso à Casa fosse um trunfo - e não como é, de fato, uma ameaça de cassação" (p.63)

A expressão "tocou fogo" pode ser relacionada ao imperador romano Nero, mas uma analogia da figura de Dirceu com um líder autoritário. Há também o uso da ironia quanto o que Dirceu argumenta como defesa:

"Dirceu depôs a portas fechadas, na Corregedoria da Câmara (...) negou as acusações, com respostas curtas 'nunca fiquei sabendo de estatal repassando dinheiro para partido'", (p.63)

Ressalte-se que a estratégia da pergunta e resposta é muito utilizada em narrativas policiais para organizar as informações. A revista faz as perguntas e ela mesma responde. Com a pergunta "José Dirceu era o chefe do mensalão?", Veja retoma pela terceira vez na mesma matéria a ideia de que Dirceu concentrava poder no governo e no PT e exercia influencia sobre as pessoas envolvidas no escândalo, entre elas, Silvio Pereira e Delúbio Soares. O trecho a seguir ilustre a situação:

"É altamente improvável até por sua personalidade concentradora, que algo parecido existisse no Congresso e não tivesse o aval ou, pelo menos, o conhecimento de Dirceu” (p.66).

Na última pergunta "O que se fará para dificultar a vida dos corruptos?" (p.66), a revista se coloca como autoridade para responder a pergunta. Por isso, o narrador é onisciente e intruso. Depois de sugerir redução de cargos no serviço público, a revista conclui a matéria com uma espécie de conselho que não é dirigida a nenhum personagem. Ao que parece, esse conselho poderia ser direcionado, de forma indireta, ao então presidente Lula, como se pode observar no trecho abaixo.

"As crises, como se sabe, são grandes encruzilhadas: delas pode-se tomar o rumo do abismo, mas não se pode seguir sem pegar o caminho da superação para melhorar" (p.67).

\section{Personagens secundários}

Na matéria em análise, são dois os personagens secundários: Maurício Marinho e Roberto Jefferson. Marinho dá detalhes do que seria, segundo Veja, "um cenário devastador das roubalheiras na estatal". Sua função na matéria é o de protagonista do vídeo que gerou a eclosão do escândalo.

Já Roberto Jefferson é o antagonista do PT e de José Dirceu. Mas na matéria, suas afirmações sobre o Mensalão são mais gerais e ele repercute a fala de Marinho. “'É mais barato pagar o exército mercenário do que dividir o poder', disse ele, referindo-se ao Mensalão, numa de suas explosivas entrevistas" (p.60). Pode-se dizer que ele é um antagonista que aponta o que a revista considera como erros, mas participa deles, uma espécie de anti-herói. Veja tem atração pelas afirmações de Jefferson mesmo sabendo que o ex-deputado teria participado do Mensalão. O personagem se mostra vingativo ("o homem bomba") e alimenta a espetacularização e a dramatização da política no caso.

\section{Considerações sobre a matéria 1 em análise}

Nesta matéria, Veja reúne vários indícios, baseados no que afirma serem características psicológicas e sociais de Dirceu, para concluir que ele pode ter sido chefe do Mensalão. Nenhuma fonte com autoridade ou provas foram ouvidas para explicar se a conclusão da revista faz sentido 
nas investigações em curso.

O que a revista deseja é um herói que possa corrigir o dano. $\mathrm{O}$ vilão, sintetizado pela revista, representa os métodos do PT de fazer política. Dirceu exerce a função de mentor, aquele que está por trás das sequências de enredo que a revista propõe relativas ao escândalo do Mensalão.

Chamada matéria 2: Muito barulho por nada - não há complô das elites, não há movimentos sociais que incendeiem o Brasil. Não há também José Dirceu, o revolucionário, mas um fantasma de uma ideia que morreu

Resumo: a matéria aponta a derrocada de José Dirceu, agora ex-ministro da Casa Civil, que pediu demissão do cargo por causa das denúncias do mensalão. A matéria faz comparações da situação de Dirceu com obras de William Shakespeare. Diz que ele é uma "fera de muitas cabeças" - frase da peça "Coriolano" e o critica por ainda resgatar certos valores revolucionários para ter seguidores fanáticos no PT.

Foto: Dirceu chegando na Câmara após a demissão da Casa Civil, rodeado de militantes do PT. Na matéria anterior, Veja chama os simpatizantes de Dirceu de "claque" e considera que sua volta não se trata de um triunfo. Há também uma foto de Dilma Rousseff que era ministra de Minas e Energia e assumiu o lugar de Dirceu. Na entrega do cargo, chamou Dilma de "camarada de armas", fazendo referência à atuação dos dois na resistência à ditadura militar.

Acontecimento-intriga: é o escândalo do Mensalão. O núcleo narrativo é a volta de José Dirceu à Câmara dos Deputados.

Narrativa: o enredo é não linear, mas nesse texto, em especial, há uma edição de fatos do passado recente (fatos ocorridos em semana ou dias), em sequencia, com a caracterização de personagens e flashbacks relacionado ao que seria Dirceu antes e depois de alcançar o poder.

Espaço predominante: Câmara dos Deputados para onde Dirceu voltou.

Ambiente: antagonismo, disputa política, crise de identidade referente ao passado e ao presente do PT e dos movimentos sociais.

Narrador principal: é onisciente e intruso, ou seja, emite opiniões. O autor do texto é Mário Sabino.

\section{Personagens}

\section{Protagonista: José Dirceu}

O narrador levanta vários questionamentos que divide o personagem entre ser um político de esquerda e alguém que, após assumir o poder, passa a ter hábitos refinados. A revista descreve o que considera intenções de Dirceu com a volta à Câmara. Para "Veja", o ex-ministro tentou resgatar um "fervor incendiário" de quando era combatente da Ditadura.

Paira sobre o personagem a negação de que houve qualquer tentativa dele de se reaproximar dos movimentos sociais e da militância do PT. Conforme "Veja", toda a movimentação de sua chegada seria uma farsa. O narrador faz uma analogia com uma peça de teatro ou uma obra de ficção por meio das expressões "efeitos coreográficos" e "estreia", e que Dirceu constrói seu próprio 
personagem, como se percebe no trecho abaixo.

"É o novo velho Dirceu que se reapresenta na Câmara dos Deputados. E com efeitos coreográficos especiais. Na sua estreia, fez-se acompanhar de um contingente de militantes embandeirados que mataram expediente nas repartições" (p.76).

Além de negar a proximidade de Dirceu com a militância do PT durante a crise do Mensalão que culminou em sua demissão da Casa Civil, "Veja" também personifica os integrantes do grupo que foi à Câmara apoiá-lo.

A expressão "militantes embandeirados" põe em dúvida o que significa ser militante. Militante é aquele que luta por uma causa. Mas aqueles que seguem Dirceu são apenas carregadores de bandeiras que conseguiram cargos de confiança no governo do PT.

Quando chama Dirceu de "novo velho", "Veja" e evidencia que o personagem é contraditório e precisa ser desmascarado: se diz de esquerda e representante de um governo que seria popular, mas, na verdade, gosta dos luxos trazidos pelo poder, como no trecho a seguir.

"[Dirceu] promoveu-se a povo não dentro daquele espírito de humildade redentora tão ao gosto da esquerda romântica” (p.76).

Na sequência, o narrador inicia suas analogias da caracterização de Dirceu com um personagem de William Shakespeare; inclusive, analisa a volta com a frase do escritor inglês de "Muito barulho por nada".

"Dirceu fez-se povo mas de acordo com a definição magistral de William Shakespeare na peça 'Coriolano' - uma fera de duas cabeças. 'Quero, em nome do PT, convocar todas as forças políticas e sociais, não só para defender, mas para discutir os rumos do governo, disse ele'”' (p.76).

Neste momento, entendemos que "Veja" inicia a desconstrução do personagem que Dirceu estaria assumindo: o de militante de esquerda e do PT, capaz de mobilizar movimentos sociais para fazerem protestos em defesa do governo diante do escândalo do Mensalão, como se vê abaixo.

"Dirceu parece ter-se livrado das tentações burguesas do champanhe cristal (900 reais a garrafa) e tinto chileno Almaviva (250 reais) que tanto os deslumbraram no poder" (p.76)

"Veja" também critica a reação dos dirigentes do PT (que chama de "caciques") que estariam divulgando que o escândalo do Mensalão seria um complô das elites para derrubar um governo operário. A convocação de Dirceu para que os movimentos sociais façam protesto é uma das justificativas para a revista chegar a essa conclusão:

"Não há movimentos sociais que possam incendiar o Brasil. O mais rebelde deles, o MST, é um bezerro satisfeito, que mana nas tetas do governo" (p.77).

Veja conclui a matéria reforçando a ideia inicial. José Dirceu, o herói da Ditadura, não existe mais. O José Dirceu ministro, poderoso, não existe mais. A ideia da esquerda salvadora, que constitui o discurso de Dirceu, também não existe mais. A função de José Dirceu é de um político derrotado mas que continua dissimulado, finge ser o que não é. Com o termo "felizmente", o narrador deixa claro que é prazeroso ver essa sequência de derrotas, como no trecho abaixo. 
"E, por fim, não há Dirceu. Pelo menos não aquele que se apresenta como Danton. Esse desceu a rampa. Tornou-se um fantasma de contornos fugidios de uma ideia que morreu há um quarto de século. Felizmente" (p.77)

\section{Secundários:}

\section{Roberto Jefferson}

Roberto Jefferson se mantém antagonista de Dirceu e é colocado como fundamental para a demissão do ex-ministro da Casa Civil. A abertura da matéria trata do assunto, demonstrando a importância da função do ex-deputado petebista na derrocada do protagonista:

"O ex-ministro José Dirceu apeado da Casa Civil cinquenta horas depois do ultimato do deputado Roberto Jefferson ('Dirceu, se você não sair daí rápido, você vai fazer réu um homem inocente, o presidente Lula'), reassumiu seu cargo de deputado federal" (p.76).

\section{Dilma Rousseff}

O passado de Dirceu na Ditadura Militar, quando ganhou evidência ao atuar no Movimento Estudantil e ao ser preso, também gera desconfiança na visão da revista. Ao comparar o ex-ministro com Dilma Rousseff, "Veja" desqualifica a atuação de Dirceu na resistencia ao governo militar em relação a sua substituta na Casa Civil.

O assunto é tratado no texto porque, durante a entrega do cargo, Dirceu chamou Dilma de "companheira de armas". A revista então reforça a negação de que Dirceu teria lutado efetivamente contra a Ditadura e à ideia de que ele seria uma espécie de herói por sua trajetória:

"Ele passou o periodo mais duro da Ditadura refestelado em Cuba, enquanto ela [Dilma] apanhava nos porões da Ditadura, na condição de comandante guerrilheira de uma facção esquerdista" (p.76).

\section{Lula}

Apesar das críticas ao governo, Veja mantém a ideia de que Lula seria uma vítima de Dirceu e que poderia ter sido traído, a partir do ponto de vista de Roberto Jefferson.

Já Olívio Dutra é criticado por dizer que alguns companheiros do PT estariam andando em "más companhias"

\section{Considerações sobre a matéria 2 em análise}

- O título é uma referência a Shakespeare. A matéria traz referências literárias e históricas, que um público leigo não entenderia. Apesar de estar no espaço destinado às matérias jornalísticas, o texto tem formato de artigo ou editorial.

- A matéria desqualifica alguns argumentos usados por Dirceu em relação, inclusive, à

\footnotetext{
${ }^{12} \mathrm{O}$ narrador se refere a Georges Jacques Danton, um dos idealizadores da Revolução Francesa.
} 
cobertura midiática do Mensalão. Diz que "não há complô das elites", "não há movimentos sociais" e "não há José Dirceu, o revolucionário, mas um fantasma de uma ideia que morreu" (pg.36).

- Dilma não era comandante guerrilheira, fazia parte de um grupo chamado VAR-Palmares e atuava nos bastidores de atuação. A palavra facção dá o tom criminalizante ao grupo e uma conotação negativa quando o chama de "esquerdista". Há muita ambiguidade nessa frase na comparação que faz aos dois personagens. A revista critica a postura de Dirceu e diz que seu heroísmo de esquerda não faz mais sentido. Depois, quando se refere a Dilma, a coloca como superior a ele no combate a Ditadura (como se fosse a verdadeira heroína da história) e ao mesmo tempo critica os movimentos de esquerda.

- A revista revê até alguns posicionamentos ideológicos e editoriais de acordo com o posicionamento de Dirceu na narrativa. O que se observa com Lula, que pode ser uma vítima traída e com Dilma, uma heroína da Ditadura que não teve a mesma visibilidade, é que Dirceu é maior vilão de todos. Qualquer um, mesmo que já tenha sido criticado pela revista, não alcança ou é vítima das tramas e conspirações de que envolvem Dirceu.

\section{3) Edição 1916 - 3 de agosto de 2005}

\section{Capa: O Risco Dirceu}

\section{Subtítulos}

- Os recados ameaçadores que ele manda ao governo

- Seu secretário particular foi autorizado a sacar dinheiro de uma conta de Valério

Chamada da matéria 1: Ele assusta o governo - No olho do furacão, às vésperas de seu duelo com Roberto Jefferson, o ex-ministro José Dirceu manda recados ameaçadores, inclusive a Lula, para evitar que sua cabeça seja dada como prêmio a oposição

Resumo: Após pedir demissão da Casa Civil, José Dirceu tenta a todo a custo, de acordo com a revista, sobreviver politicamente diante das denúncias de que teria articulado o esquema do mensalão. Isso estaria se dando por meio de ameaças diretas a Lula e a cúpula do PT.

Capa: foto do rosto de Dirceu com o fundo preto. Há uma divisão na foto. De um lado, o rosto de Dirceu está claro. Do outro, está escuro. São várias interpretações. O fundo preto pode significar o momento difícil que ele estava vivendo: foi acusado de chefiar o Mensalão, demitido da Casa Civil e prestes a ter o mandato de deputado federal cassado. O jogo do claro-escuro no rosto do personagem, remete a primeira edição analisada. Ele teria dois lados. Um que mostra e outro que não. Na posição de narradora principal, caberia Veja mostrar o lado escuro, o que é feito nos bastidores, quem seria o verdadeiro José Dirceu a partir da descrição psicológica de que o exministro é capaz de articular traições para conseguir o que quer. Dirceu representa um risco ao governo, mesmo estando fora dele: manda recados ameaçadores. A capa também traz um anúncio da matéria seguinte sobre o assessor de Dirceu que teria sacado dinheiro de uma conta de Marcos Valério, o operador do Mensalão.

Foto Principal: foto do rosto de Dirceu, dessa vez, sem o jogo do claro-escuro. Na imagem, o 
personagem parece tenso, com a mão na boca (essa é foto foi utilizada na capa do livro "Dirceu", de Otávio Cabral, ex-editor de Veja). Na matéria, a revista traça um perfil psicológico de Dirceu diante da possibilidade de ser cassado pela Câmara e como ele estabeleceu um círculo de relações no Planalto e na cúpula do PT. Segundo Veja, Dirceu estaria ameaçando o governo ao dizer o que sabe. A mão na boca dá a entender que ele ainda está em silêncio. Porém, é um arquivo vivo do governo.

Recursos Gráficos: o fundo das duas páginas de abertura segue o modelo da capa e também são pretas. A montagem da matéria privilegia as fotos de todos os personagens citados que são aliados ou antagonistas de Dirceu. Destaque para a foto em que Dirceu e Lula estão frente a frente. Veja reforça a ideia apresentada em edições anteriores de que os dois não são amigos íntimos, que a relação entre eles é política, e há tensão psicológica, principalmente por parte de Lula nessa relação.

Narrativa: O acontecimento-intriga continua sendo o escândalo do Mensalão e o núcleo narrativo da matéria é a preparação de José Dirceu para o encontro com Roberto Jefferson em uma audiência do Conselho de Ética da Câmara, diante da possibilidade do ex-ministro ter o mandato cassado. A matéria é construída a partir da relação entre Dirceu, aliados e antagonistas. O enredo é não linear, o narrador principal encaixa momentos do passado recente com o que estaria acontecendo no presente para demonstrar que as funções de José Dirceu no governo poderiam ter culminado na existência do esquema do Mensalão. Posteriormente, no mesmo texto, o narrador desenvolve outra história - vemos aqui o exemplo de narrativa de alternância, previsto em Todorov - que é a construção psicológica de Dirceu em relação à crise que envolve a tensa correlação de forças com Lula e demais petistas que estariam abrindo mão de defender o ex-ministro em nome da integridade do então presidente da República.

Espaço predominante: Palácio do Planalto, Congresso Nacional, apartamento onde José Dirceu morava quando era deputado em Brasília. Não há descrição física desses espaços na matéria.

Ambiente: tensão, incerteza, acordos políticos e possibilidade de traição.

Narradores principais: são oniscientes e intrusos. A autoria da matéria é de Otávio Cabral e Julia Duailibi.

\section{Personagens}

Nesta matéria, Veja traça as relações entre os personagens citados com José Dirceu. As tramas mais marcantes são sobre a relação entre Dirceu e Delúbio Soares e de Dirceu e Lula, que serão destacadas na análise. A revelação feita por Renilda Santiago, mulher de Marcos Valério, de que o ex-ministro teria se encontrado com executivos do Banco Rural, é o gancho da matéria, mas Lula e Delúbio tem mais espaço, por evidenciarem os bastidores do poder, além da carga dramática sobre os fatos relatados.

Veja constrói o perfil de Delúbio e Dirceu, os coloca "frente a frente", dá começo, meio e fim a relação dos dois e os trata como antagonistas. A história dos personagens inicia com a informação de que Dirceu seria uma espécie de mentor de Delúbio ao torná-lo tesoureiro do PT. Ele teria o aval do ex-ministro para ter status no governo Lula.

De acordo com a revista, o antagonismo começa quando Dirceu percebe que Delúbio estaria tendo acesso direto a Lula. Conforme observado em edições anteriores, Veja traz como um dos episódios 
da crise vivida pelo Planalto com o escândalo, como no exemplo a seguir.

Desde o início do governo, [Delúbio] transitava livremente pelos principais gabinetes de Brasília como se fosse autoridade. $O$ ex-tesoureiro era visto com frequência no 40 andar do Palácio do Planalto, onde funciona a Casa Civil e chegou a integrar comitiva presidencial em viagens ao exterior (...) Dirceu tem dito a interlocutores que suas relações com Delúbio não eram tão boas (...) "Delúbio estava deslocado, agindo por conta própria, falando diretamente com o presidente", disse o ex-ministro. (p.55)

Mas para explicar o alcance de Delúbio em suas funções no PT, Veja levanta características sociais e psicológicas de Dirceu, que podem justificar seu poder tanto no âmbito do governo, como ministro, quanto no partido após ter deixado o cargo de ministro chefe da Casa Civil.

Entre as características sociais destacadas por Veja, Dirceu foi o arquiteto da campanha de 2002 que elegeu Lula, montou o governo. Por ser um rosto de comando, um "manda-chuva", Veja aponta que Dirceu promoveu lideranças do PT que aparecem envolvidos no escândalo. Após a descoberta do Mensalão tinha se tornado ex-todo poderoso, porém ainda era um arquivo vivo:

"[Dirceu] viu-se incumbido, ainda, da montagem do governo em todas as esferas, atendendo a interesses políticos legítimos e também aos inconfessáveis. Como chefe da Casa Civil comandou a máquina administrativa (...) José Dirceu tem a memória boa e ruim do governo Lula” (p.55)

Já as primeiras características psicológicas destacadas pela matéria são as negativas de Dirceu sobre sua caracterização social. O ex-ministro nega ser centralizador, diz que fez tudo (montagem do governo) com o aval de Lula. Percebe-se que o narrador encaixa todos esses fatos para indicar que Dirceu estaria chantageando o presidente, que iria dizer o que sabe.

Conforme a revista, no momento presente, também faria sentido Delúbio ser uma ameaça para Dirceu e ao governo por assumir a responsabilidade pelo Mensalão. O tesoureiro, que havia sido promovido por Dirceu e ganho espaço no Planalto, seria outro arquivo vivo do PT e do governo.

Após desenvolver a narrativa sobre a relação que considera antagônica entre Dirceu e Delúbio, Veja afirma que o então tesoureiro poupou o ex-ministro em relação ao que disse sobre o Mensalão. A revista ainda aponta que a "turma de Dirceu" também estaria disseminando informações de que o publicitário Marcos Valério teria se encontrado com Lula no Palácio do Planalto, como pode-se identificar a seguir

"O curioso é que, ainda assim, Delúbio fez questão de preservar Dirceu em seu depoimento à CPI, dizendo que o ex-ministro não sabia nadica de nada dos empréstimos (...) No depoimento, Delúbio afirma que usou recursos do caixa dois do PT para financiar a festa de posse de Lula. Por último, ninguém consegue expulsar Delúbio do PT, apesar de todos os seus trambiques, com medo da reação do ex-ministro. Isso que é inimizade"(p.59).

Observamos aqui um ponto de virada na história. Apesar da crise, a revista aponta que o exministro ainda é um manipulador político nos bastidores, inclusive de Delúbio, e questiona o antagonismo que ela mesma levantou na matéria. A lealdade do ex-tesoureiro a Dirceu seria, para revista, um sinal de que Dirceu ainda exercia um tipo de poder.

\section{Lula x Dirceu}


Após contar como se daria a relação entre Dirceu e Delúbio e contextualizá-la com o escândalo do Mensalão, Veja parte para outro momento em sua narrativa que se dirige a a analisar quais as implicações da convivência entre Dirceu e Lula para o futuro político dos dois.

A revista utiliza novamente descrições psicológicas e sociais para desenvolver a trama. De um lado, Lula, presidente da República, que já estaria em processo de afastamento de Dirceu desde quando ele ainda era ministro, tentando se preservar em meio ao escândalo que eclodiu em ano pré-eleitoral, como se percebe abaixo.

"[Dirceu] comenta que o presidente tinha ciúmes de sua capacidade administrativa. Todas as vezes que apareciam notícias de que ele deixaria o governo, contou o ex-ministro a um amigo, havia uma fileira de pedidos a seu favor. Isso irritava o presidente (...) a situação, de acordo com relatos de Dirceu, chegou a tal ponto que o presidente passou a não convidá-lo para eventos e encontros importantes" (p.59).

Do outro lado, Dirceu, ressentido pela forma como teria sido tratado após seu nome figurar entre os supostos articuladores do Mensalão. Durante a análise das edições até o momento, é a primeira vez que Veja tentar humanizar a figura de Dirceu. A revista descreve as frustrações que estariam sendo vividas pelo ex-ministro com base em depoimentos de interlocutores não identificados.

Veja sugere que Dirceu se sentiu traído e esperava a gratidão de Lula naquele momento difícil. E aponta também a expectativa do ex-ministro era ser o sucessor do então presidente. Em relação a demissão da Casa Civil, o narrador detalha como teria sido a conversa entre Lula e Dirceu em um primeiro momento:

"O ex-ministro diz que, por culpa de Lula, saiu do governo de maneira humilhante. Afirma que decidiu deixar o cargo logo depois das primeiras acusações do deputado Roberto Jefferson de que ele seria o chefe do Mensalão (...) Lula teria pedido para que ele [Dirceu] ficasse” (p.60).

Depois, a revista, algo também o observado nas duas edições anteriores, inclui o ex-deputado Roberto Jefferson como aquele que teria provocado a derrocada de Dirceu, uma espécie de pivô da separação entre Lula e o ex-ministro:

"O então ministro saiu do [Granja do Torto, uma das residências do presidente] se sentindo prestigiado e decidido a enfrentar a crise ainda como homem poderoso. Dois dias depois (...), e horas após o famoso discurso de Jefferson em que ele aconselha Dirceu a deixar o governo, foi chamado no gabinete do presidente. 'Acho melhor você sair', disse Lula" (p.60).

Segundo o que foi mostrado na fundamentação teórica desta pesquisa, o jornalismo político se utiliza dos elementos da narrativa fíccional com o objetivo de dramatizá-la. Portanto, o antagonismo entre Dirceu e Jefferson é um dos elementos que move a narrativa sobre o Mensalão, como se depreende do trecho abaixo:

"Dirceu, ele e o governo se transformaram em reféns de Roberto Jefferson. Ao narrar esse episódio aos seus assessores, Dirceu se referiu a Lula com os mesmos termos que um torcedor de futebol costuma dedicar ao juiz que marcou um pênalti injusto contra seu time” (p.60).

Dando continuidade à descrição psicológica de Dirceu, Veja afirma que o ex-ministro estava isolado, preparando sua defesa para levá-la à audiência no Conselho de Ética, e recebeu em seu 
apartamento vários aliados, todos citados como envolvidos no esquema que levou ao Mensalão. Ele estaria se sentindo ameaçado por ex-aliados e temia ser um trófeu para a oposição ameaçar politicamente o PT.

Neste momento, a revista confirma que Dirceu teria razões para estar com medo: o PT e o governo já estariam se articulando com a oposição para garantir a preservação de Lula em troca da cassação do ex-ministro:

"O governo até já nomeou um interlocutor para discutir com a oposição a lista da guilhotina. José Dirceu é o primeiro nome da lista oficial. O algoz petista é o secretário-geral do PT e ex-ministro do Trabalho Ricardo Berzoini (...) em troca quer a preservação de Lula e a entrega de alguns oposicionistas, como Eduardo Azeredo, que usou valerioduto em sua campanha ao governo de Minas Gerais em 1998” (p. 60 e 61).

\section{Renilda x Dirceu}

O depoimento de Renilda Santiago, mulher de Marcos Valério, é o gancho da matéria. O episódio piorou a situação de Dirceu, que já estava em vias de ter o mandato cassado pela Câmara. A rede de intrigas e possíveis chantagens ainda não tinham aparecido de forma detalhada nas revistas analisadas anteriormente, quando as informações sobre o Mensalão ainda pareciam desencontradas.

O fato de Renilda ser a mulher do publicitário apontado como operador do esquema reforça a ideia de Waisbord (2000) de que os escândalos político-midiáticos se fortalecem quando alguém da família dos envolvidos resolve falar. O autor cita o exemplo da entrevista de Pedro Collor de Melo à Veja, irmão do ex-presidente Fernando Collor. A cobertura que levou ao impeachment de Collor ganhou mais sustentação com o depoimento de Pedro.

Renilda contou, no depoimento, que Valério disse a ela ter ouvido de Delúbio Soares que Dirceu teria se encontrado com executivos do Banco Rural e que o ex-ministro sabia do esquema do Caixa 2. Veja destaca que ela deu essa informação mesmo sem ter sido questionada. Entende-se que ao dizer isso na matéria, a revista tenta dar credibilidade ao que o Renilda relatou. Ela teria feito de forma espontânea, sem pressões.

De acordo com Veja, em um primeiro momento, Dirceu se calou diante da denúncia. Depois confirmou o encontro, após o banco se manifestar oficialmente sobre as reuniões e dizer que elas aconteceram em decorrência do interesse do Banco Rural em comprar o Banco Mercantil de Pernambuco.

A revista faz uma referência ao que descreveu no início da matéria e se utiliza da ironia como recurso de linguagem pois já tinha dito que Dirceu teria a memória boa e ruim do governo Lula: "Só após o Banco Rural ter emitido uma nota confirmando a reunião é sua memória [se referindo a Dirceu] sempre muito boa funcionou” (p.62).

O uso da ironia também deixa claro que Veja reforça a ideia de que Dirceu poderia estar mentindo e que o ex-ministro despertava desconfiança. Essa afirmação é confirmada quando a matéria aponta que o assunto tratado no encontro do ex-ministro com executivos do Banco Rural "está completamente fora das atribuições" de chefe da Casa Civil. Então, a revista liga esse ponto com o assunto da matéria seguinte. Percebe-se, pela primeira vez, dentro do recorte da pesquisa, o encadeamento entre as matérias analisadas 
Chamada da matéria 2: Aonde Dirceu vai... Bob vai atrás - documento em poder da CPI mostra que ajudante e amigo do ex-chefe da Casa Civil foi autorizado por Marcos Valério a sacar 500 mil reais no Rural

Resumo: a matéria trata do envolvimento do assessor de José Dirceu Roberto Marques, conhecido como Bob, em um suposto saque de 500 mil reais da conta de Marcos Valério. A revista classifica o caso como o mais forte indício de que Dirceu teria alguma ligação com o esquema do Mensalão até o momento.

Foto principal: Foto de José Dirceu caminhando com Roberto Marques, o assessor está o seguindo com uma pasta na mão. Vale destacar a legenda da foto: "o que será que o ajudante Bob Marques carregava na mala da foto? Documentos, autorizações de saque, fotos de Fidel Castro, as cuecas de José Dirceu? Os dois, segundo Bob, são amigos há mais de vinte anos” (p.64).

A imagem é altamente significativa para a caracterização de Dirceu construída por Veja nas edições anteriores analisadas. A presença de um empregado fiel, que é chamado pelo apelido (Bob), conhecido popularmente como aquele "testa de ferro", que faz o trabalho sujo dá a Dirceu a função de chefe na narrativa.

No caso, não se trata de liderança política e influência, como foi destacado na matéria anterior, mas a chefia de algo considerado ilícito e o uso de gente anônima para fazer as coisas por ele.

Na legenda, a revista expressa ironia e sarcasmo, colocando na "mala" várias referências à vida particular de Dirceu (cuecas), ideológica (Fidel) e os indícios de participação no mensalão (documentos, autorizações).

Recursos gráficos: a revista mantém o padrão da matéria anterior. A imagem fo suposto documento de autorização de saque aparece nas páginas 65 e 66. Isso demonstra que o documento é muito importante para a revista, que ainda não tinha sido noticiado um indício da investigação da CPI dos Correios que liga alguém próximo a Dirceu no escândalo do Mensalão.

Narrativa: $O$ acontecimento-intriga é o escândalo do Mensalão e o núcleo narrativo é a autorização de saque de R \$ 50 mil no Banco Rural para o secretário particular de Dirceu. O enredo é linear. Dessa vez, a revista enumera possíveis fatos relacionados ao documento e ao saque. $\mathrm{O}$ caminho percorrido até o saque, de acordo com a revista, não teve participação presencial de Dirceu. Há entrevistas aspeadas com os supostos envolvidos. Nenhum deles assume a responsabilidade. Observa-se uma narrativa mais concreta, factual e menos dramática. Porém, que se trata de Dirceu, prevalecem as descrições psicológicas e as conversas de bastidores com diálogos entre personagens que expressam o clima de tensão vivido por ele durante o curso das investigações da CPMI dos Correios.

Tempo: Prevalece o tempo cronológico e a descrição de episódios ocorridos no momento presente, apesar da revista fazer previsão do que poderia acontecer nas próximas semanas. Não há resgate, relacionado a Dirceu, de situações que ocorreram em um passado mais distante.

Espaço predominante: Congresso Nacional, Banco Rural em Belo Horizonte, Palácio do Planalto, residência de José Dirceu (não identifica se é em São Paulo ou em Brasília).

Ambiente: Tensão, de investigação e aparecimento de possíveis provas. 
Narrador principal: Onisciente e intruso. A matéria é de autoria de Julia Duailibi e Victor Morino. A narração é dividida com entrevistados e fontes não identificadas.

\section{Personagens}

José Dirceu é o protagonista da narrativa. Algumas ações são atribuídas a Roberto Marques, porém sem participação presencial. Na matéria, José Dirceu assume a função de mentor do assessor. Assim como apareceu na matéria de abertura em relação a Delúbio Soares.

Roberto Marques é entrevistado, mas os narradores principais fazem juízo de valor quanto a veracidade das explicações dele. Defendem também a legitimidade do documento e do envolvimento de Dirceu a partir da relação pessoal do ex-ministro com o assessor.

A parceria entre Bob e Dirceu é tão intensa que o assessor chegou a representar oficialmente o então ministro da Casa Civil em solenidades (p.65).

O problema é a CPI resolveu investigar e descobriu que a autorização foi, sim, dada ao assessor legislativo [Roberto Marques], embora ele não tenha sido o autor do saque. "Só pode ser armação para complicar a vida do Zé Dirceu”, afirma [Roberto]. Esse Bob é mesmo esponja” (p.66).

Outro recurso de descrição utilizada pela revista e encontrado nas edições anteriormente analisadas é a incerteza sobre a procedência dos personagens e quais funções exercem para comprovar o clima de desconfiança.

Bob é uma espécie de secretário particular de Dirceu. Faz as vezes de motorista, de despachante e carregador de bagagem. Funcionário da Assembleia Legislativa de São Paulo, ninguém sabe direito o que é realmente - só que está sempre na companhia de Dirceu (p.65).

A revista destaca que Dirceu e Roberto são amigos há 20 anos e que o assessor faz companhia ao ex-ministro. Veja o chama, de forma irônica, de "amigo secretário". A indefinição do que seria público e privado é observada ao longo da narrativa. O grande questionamento que tenta ser respondido pela revista é se a relação entre Roberto e Dirceu seria profissional ou de subserviência.

Na matéria, os narradores principais apontam dois petistas como "pedras no sapato de Dirceu". O sub-relator da CPMI dos Correios Carlos Abicail (MT) e o presidente da Comissão Delcídio Amaral. Abicail, no âmbito da CPMI, segundo Veja, que a autorização do saque foi dada ao assessor de Dirceu e não um homônimo que como havia alegado Roberto Marques.

Segundo os narradores principais, Dirceu teria conhecimento da autorização e sabia que o documento viria a público.

A partir de então, a revista retoma o uso de recursos dramáticos para descrever, com detalhes, episódios ocorridos nos bastidores. Na matéria, o episódio seria o encontro entre Delcídio Amaral e José Dirceu. De acordo com a descrição psicológica de Veja, Dirceu estava preocupado e incomodado com a rapidez das investigações da CPMI e os vazamentos de documentos, como se observa a seguir:

Desde o início da semana passada, Dirceu procurava insistentemente falar com o presidente da CPI, o senador Delcídio Amaral. Na terça-feira, Delcídio foi à casa do ex-ministro, onde passou meia hora. Os dois tiveram uma conversa dura, segundo relatos ouvidos por membros da CPI 
(p.66).

No trecho acima, os narradores principais se utilizam de detalhes temporais: datas e duração da conversa. Trata-se de uma estratégia argumentativa recorrente no jornalismo para provocar no destinatário a credibilidade que a informação é verdadeira.

A suposta preocupação de Dirceu o leva, conforme a revista, a tentar negociar com Delcídio uma forma de evitar um depoimento na CPMI. Veja aponta que tal atitude desperta suspeitas sobre a responsabilidade do ex-ministro no esquema.

(...) um estranho incômodo para quem [José Dirceu], em tese, nada tem a ver com o assunto (...). Por fim, fez uma proposta indecorosa ao presidente da CPI. Sugeriu a Delcídio que barganhasse seu depoimento em troca da não-convocação do presidente do PSDB, Eduardo Azeredo, cujo nome também apareceu como beneficiário do dinheiro de Marcos Valério. Delcídio desconversou (p.66).

Esse trecho evidencia várias caracterizações do protagonista já sustentada por Veja nas edições anteriores analisadas. Dirceu continua sentindo as consequências de sua derrota política, após sua demissão da Casa Civil. Os próprios colegas de partido não se mobilizam para ajudá-lo. Ele tenta persuadir por vantagens como se ainda tivesse o poder de influência, que estava se esgotando com o escândalo. Quando se trata de Eduardo Azeredo, presidente do principal adversário do PT, Dirceu demonstra pragmatismo na busca por conseguir o que quer, já que o envolvimento de Azeredo em esquema semelhante e sua visibilidade poderia ser um ganho político para o PT diante da crise.

Segundo Veja, Dirceu comentava nos bastidores que poderia argumentar que o documento de autorização seria um papel avulso, sem validade jurídica. Sobre o aparecimento do nome do seu secretário particular, ajudante, amigo e, agora se sabe, pau pra toda obra, Dirceu mandou dizer que tudo indica tratar-se de uma 'plantação' para prejudicá-lo (p.66).

\section{4) Edição 2232 - 31 de agosto de 2011}

Capa: O Poderoso Chefão - o ex-ministro José Dirceu mantém um "gabinete" num hotel de Brasília onde despacha com graúdos da República e conspira contra o governo da presidente Dilma

Chamada: Ele ainda manda em ministro, senador... - Há muitas histórias em torno das atividades do ex-ministro José Dirceu. Veja revela a verdade sobre uma delas: mesmo com os direitos políticos cassados, sob ameaça de ir para a cadeia por corrupção, o chefe da quadrilha do mensalão continua o todo-poderoso comandante do PT. Dirceu é um homem de negócios, mas continua a ser um homem do partido. O "ministro" como ainda é tratado em tom solene pelos correligionários, mantém um gabinete em um hotel em Brasília, onde despacha com senadores, deputados e até ministro de Estado - reuniões que aconteceram em horário de expediente como se ali fosse uma repartição pública. E agoracom um ingrediente ainda mais complicador: ele usa o poder e toda a influência que ainda detém no PT para conspirar contra o governo Dilma - e a presidente sabe disso.

Resumo: é a polêmica matéria que a Veja utilizou câmeras para espionar Jose Dirceu em um hotel em Brasília. O equipamento foi utilizado no corredor onde ficava o quarto dele e, dessa forma, foi possível registrar as pessoas que o ex-ministro recebia. Veja faz associações das visitas com um eventual poder que Dirceu ainda teria sobre o PT, inclusive chamando o quarto de bunker. Veja enumera o que Dirceu estaria fazendo profissionalmente, entre as atividades, consultorias 
milionárias a empresas. Por causa dessa matéria, Dirceu registrou boletim de ocorrência contra Veja por invasão de privacidade.

Capa: Foto de Dirceu usando óculos escuros e sorrindo. O fundo tem, assim como em outras edições, jogo de cores. A parte de cima é branca, ao meio cinza e, ao fim, preto. A relação claroescuro, observadas nas outras edições, evidencia que a revista atribui a Dirceu um lado obscuro, que a revista se encarrega de desvendar, tornar público.

O título "O Poderoso Chefão" é uma referência aos nome dos três filmes, dirigidos por Francis Ford Copolla, nos anos 70, baseado no livro de Mario Puzo. Inicialmente, a história se passa na década de 40, quando cinco famílias da máfia disputam poder e dinheiro em Nova York e New Jersey, nos Estados Unidos. O protagonista do primeiro filme é Vito Corleone (Marlon Brando), o chefe de uma dessas famílias, que dirige os negócios e está sempre rodeado de aliados e inimigos.

Grafia do título na capa da revista, especialmente o nome "Chefão" traz semelhanças em relação à grafia do título que consta nos cartazes do filme. O título original é "The Godfather". No cartaz, há uma mão manipulando cada letra da palavra "Father" como se fossem marionetes. Na capa de Veja, o mesmo acontece com a palavra "Chefão": percebe-se que fios estão ligados a cada letra, porém sem a mão e a cruzeta que sustenta os fios.

De acordo com Menegatti e Teixeira (2012) que analisam o cartaz do filme baseados em preceitos semióticos, a mão e a cruzeta representam símbolos de dominação. "A mão, por si só, já tem um significado de poder, e as marionetes representam a influência que o chefe da máfia exerce sobre outras pessoas" (p.7).

Foto Principal: Ilustração gráfica feita a partir de uma foto de Dirceu, também de óculos escuros onde predominam as cores preto, vermelho e branco. O personagem está em pose informal, segura o paletó para trás e usa uma gravata vermelha. A ilustração transmite a ideia da reportagem: ele não é mais ministro (ou seja, não tem mais obrigação de usar o paletó), porém insiste em continuar mandando. $\mathrm{O}$ tipo de óculos escuro usando tanto na capa, quanto na foto principal, transmite a ideia de poder e soberba, de alguém que esconde algo ou quer se disfarçar, observados em outros personagens fictícios ligados à máfia, como é possível observar na foto a seguir: 

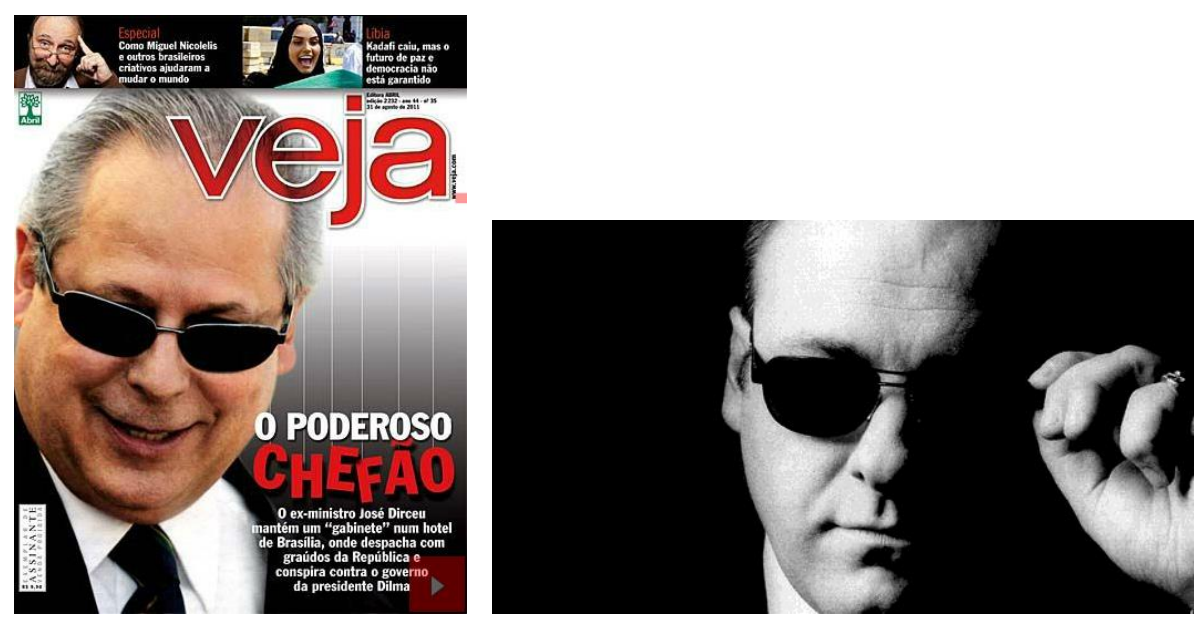

Figura 1: José Dirceu e Tony Soprano: o destaque é o mesmo modelo de óculos, que remete ao poder

A imagem é de uma das cenas do seriado "The Sopranos", da HBO, que conta a história de um chefe de máfia na atualidade (diferente de Don Corleone, que se passa na década de 40), Anthony Soprano (James Gandolfini) comanda os negócios da família, porém dentro de um ciclo antiheróico: apesar de viver do crime é um bom pai e faz terapia para tratar uma síndrome do pânico. Como veremos mais adiante, Veja associa Dirceu ao imaginário em torno da máfia, porém não ressalta nenhuma qualidade positiva do personagem.

Recursos Gráficos: as fotos das visitas são em preto e branco, capturadas por câmeras de segurança, cujo acesso ao público é restrito. Em cada foto, as visitas são identificadas, inclusive porque as imagens são ruins e também porque são 10 pessoas que Dirceu recebeu em um quarto de hotel entre os dias 6 a 8 de junho. Além das datas, as legendas trazem a duração de cada conversa e a explicação de cada um sobre o motivo e o que foi dito na reunião. Esse recurso facilita a leitura, traz as informações fundamentais para que o destinatário compreenda e assimile a ideia de que, mesmo sem ocupar função pública, Dirceu recebeu várias visitas, de deputado, senador, ministro e presidente de estatal em espaço curto de tempo. Para a revista, tratou-se de articulações e conspirações que estavam sendo feitas em segredo.

No restante das páginas, prevalecem o preto, o branco e o vermelho. Traz fotos dos personagens citados na matéria, com destaque para Antônio Palocci, que seria o centro dos assuntos que teriam sido tratados nas reuniões com Dirceu.

Narrativa: Dessa vez, o acontecimento-intriga não é mais escândalo do Mensalão e sim as escolhas da presidente Dilma Rousseff, eleita em 2010 como sucessora de Lula, para cargos de confiança. O núcleo narrativo é a atuação de Dirceu nesse contexto: estaria se articulando para conseguir cargos para seus aliados no governo, por isso, o motivo das reuniões, às vésperas da demissão do então chefe da Casa Civil Antonio Palocci. O enredo é não-linear porque, apesar das visitas serem enumeradas de forma cronológica, a matéria começa resumindo o passado de Dirceu, da Ditadura até o Mensalão, para então tratar do momento presente. O resgate da trajetória de Dirceu é recorrente nas matérias de Veja sobre o personagem, com o objetivo de desconstruir o imaginário heróico sobre ele.

Espaço predominante: é o hotel onde Dirceu estava hospedado e foram realizadas as reuniões. O 
Palácio do Planalto também é citado.

Ambiente: é de articulação política e possível conspiração feitas por Dirceu, que afetaria Dilma Rousseff. A revista também cita um clima de suspeitas em torno do que o personagem estaria fazendo no tempo presente.

Narradores principais: são os repórteres Daniel Pereira e Gustavo Ribeiro. A reportagem cita fontes ligadas ao governo e ao PT mas não cita nomes.

\section{Personagens:}

O protagonista é José Dirceu. Veja aponta que seis anos após o escândalo do Mensalão, mesmo com os seus direitos políticos cassados, ele continua se reunindo com nomes importantes do governo e do PT. Com a narrativa do mensalão consolidada e no aguardo do julgamento pelo Supremo Tribunal Federal - STF, a revista reconstrói o personagem que não aparecia na capa da revista desde 2005. Usa referências do passado: ditadura, fundação do PT, eleições 2002, o cargo de ministro Chefe da Casa Civil e a queda em 2005 (de certa forma, traça o ciclo do herói do personagem, que se encerra com o escândalo).

O resgate do passado de Dirceu para justificar o que ele faz no presente é novamente observado. As características principais atribuídas ao ex-ministro na matéria é a de "chefe de quadrilha" (uma das acusações judiciais no processo que tramitava no STF), conspirador, audacioso e ganancioso por dinheiro em função de ser consultor de empresas das áreas de petróleo e gás. Veja descreve o que seria o clima das relações entre Dirceu e os visitantes. Ele ainda é o "chefão", dá ordens para ministro, senador e deputado, tem poder nos bastidores, gosta de ser chamado de ministro e desperta suspeitas.

"A três quilômetros do Palácio do Planalto, Dirceu mostra que suas garras estão afiadas (...) José Dirceu não vai até as autoridades. As autoridades é que vão a José Dirceu. Essa inversão de papeis poderia se explicar por uma natural demonstração de respeito pelos tempos em que ele era do governo. Não é. É uma efetiva demonstração de que o chefe ainda é poderoso" ( $p .74$ e 75).

Em seguida, a reportagem relaciona as ações do presente com o passado da atuação de Dirceu na Ditadura Militar. Uma delas é a clandestinidade. Após temporada de exílio em Cuba, onde diz ter participado de treinamentos de guerrilha, o ex-ministro voltou ao Brasil, na década de 70, com outra identidade e a manteve por três anos até a Anistia.

No tempo presente, Veja dá exemplos de que Dirceu coloca em prática o que aprendeu e viveu na Ditadura. Diz que os encontros no quarto do hotel, que a revista compara com um bunker, foram realizados em segredo, que o ex-ministro convoca seus aliados como soldados. Alguns seriam até adversários internos no PT, como o então ministro José Pimentel, mas ele se alia com quem tem interesses em comum, é pragmático. O uso de termos usados na linguagem militar evidencia outra característica atribuída ao personagem: o autoritarismo.

Os visitantes registrados por Veja foram: Fernando Pimentel (então ministro do Desenvolvimento); os senadores petistas Walter Pinheiro, Delcídio Amaral e Lindbergh Farias; José Sérgio Gabrielli (então presidente da Petrobras), o senador Eduardo Braga (PMDB); o deputado federal Devanir Ribeiro (PT); o deputado federal Candido Vacarezza (PT) e o deputado federal Eduardo Gomes (PSDB). 
Ao longo da matéria, Veja constrói vários cenários de antagonismo que envolvem Dirceu, Palocci, a presidente Dilma e a própria revista que serão detalhados a seguir.

\section{Dilma x Dirceu}

O governo Dilma Rousseff começou em janeiro de 2011. No primeiro semestre, a presidente realizou uma série de demissões nos ministérios e outros órgãos após denúncias de corrupção divulgadas pela imprensa. Apesar de não estar envolvido diretamente em nenhum dos esquemas, o ministro-chefe da Casa Civil Antonio Palocci também foi demitido, após divulgação de que teria faturado milhões por meio de consultorias.

Veja, por meio dos narradores principais, dá indícios de que apoia a presidente em relação às demissões e se coloca como o narrador que alerta o personagem dos perigos que corre. Esse perigo seria Dirceu que, ainda influente no PT, estaria conspirando contra ela e cobiçando cargos vagos deixados pela demissão de Palocci.

Segundo a matéria, Dilma sabia das reuniões e não estaria cedendo à pressão de manter nos cargos pessoas ligadas ao ex-presidente Lula e a Dirceu. A resistência se estendia também a escolha de ministros estratégicos, como se observa abaixo.

"Dilma está resistindo bem. Uma faxina menos visivel é a que ela está fazendo nos bancos públicos. Aos poucos, vem substituindo camaradas ligados a Dirceu por gente de sua confiança. E o chefão não está nada contente com isso. Tanto que tem alimentado o noticiário com denúncias contra pessoas muito próximas a presidente" (p.80).

Dirceu estaria se articulando para que Cândido Vacarezza, um dos participantes das reuniões, fosse escolhido para a pasta de Relações Institucionais. Porém, a presidente nomeou Ideli Salvatti para o cargo. De acordo com a revista, a situação de José Sérgio Gabrielli era instável e ele procurou Dirceu para continuar no cargo de presidente da Petrobras. O ex-ministro, por sua vez, lucraria financeiramente com a manutenção de Gabrielli.

“A presidente não cultiva nenhuma simpatia por ele [Gabrielli]. Palocci pretendia tirar Gabrielli do comando da estatal. Gabrielli precisava - e precisa - do apoio, sobretudo do PT, para se manter no cargo. Dirceu é consultor de empresas do setor de petróleo e gás. Precisa manter-se bem informado no ramo para fazer dinheiro" (p.76).

O passado de Dilma na Ditadura Militar - ela fez parte do grupo guerrilheiro VAR-Palmares - vem à tona para justificar o presente num patamar de igualdade a Dirceu quanto a alguns métodos de fazer política para enfrentá-lo.

"Mas Dilma também conhece bem os caminhos da guerrilha política. Chamada de 'minha camarada de armas' por ele quando lhe foi passado o comando da Casa Civil, em 2005, a presidente não perde de vista os passos do chefão. Como? Pedindo a algumas autoridades que visitam Dirceu em Brasília informações sobre suas ambições" (p.80).

Conclui-se, então, que Dilma exerce a função de heroína na matéria. A narrativa de Veja leva a crer que a presidente está tentando reparar os danos deixados pelo ex-presidente Lula. Este e Dirceu representariam o lastro de corrupção do governo anterior, que foi marcado pelo escândalo do Mensalão. 


\section{Dirceu x Palocci}

O antagonismo entre José Dirceu e Antônio Palocci gira em torno dos cargos que seriam deixados após sua demissão. Na matéria, a revista também deixa claro que os dois já disputavam poder durante o primeiro mandato do governo Lula, inclusive a possibilidade de serem nomes naturais para a sucessão presidencial. Palocci era ministro da Fazenda e foi demitido em 2006, após denúncias de recebimento de propina e de ter invadido a conta do caseiro Francenildo Santos Costa que seria testemunha de acusação no caso.

Em 2011, Palocci se tornou ministro-chefe da Casa Civil no início do governo Dilma Rousseff, mas ficou no cargo até junho do mesmo ano. Ele não conseguiu permanecer após a divulgação de que teria feito consultorias milionárias. Segundo Veja, Dirceu foi um dos nomes que influenciou a segunda demissão de Palocci. Uma das justificativas da revista é a reunião com Delcídio Amaral, Walter Pinheiro e Lindbergh Farias que estariam "insatisfeitos com Palocci" (p.78), conforme se observa no trecho a seguir.

"No governo Lula, o ex-ministro Antônio Palocci perdeu o cargo depois de quebrar o sigilo bancário de um caseiro que o acusava de frequentar uma casa de lobistas. No governo Dilma, foi demitido por não conseguir explicar a origem de sua fortuna obtida de forma meteórica. Dessa última vez, no entanto, o processo de fritura de Palocci contou com a ajuda de José Dirceu” (p.75).

De acordo com a revista, mesmo com as reuniões, a tentativa de Dirceu de preencher os cargos deixados pela saída de Palocci não vingaram. Como foi citado acima, Dilma Rousseff escolheu Gleisi Hoffman para a Casa Civil e Ideli Salvatti para Relações Institucionais.

\section{Dirceu x Veja}

A revista também se coloca como heroína e antagonista de José Dirceu por ter descoberto o que seriam ações secretas e conspiratórias do ex-ministro. Ainda mais por se tratar de reuniões realizadas no âmbito privado com pessoas públicas. Os narradores emitem opinião sobre as acusações que pesavam sobre Dirceu.

Os métodos de apuração para a reportagem também causaram polêmica na época da publicação. O hotel onde foram realizadas as reuniões registrou um Boletim de Ocorrência, em uma delegacia de polícia em Brasília, por violação de domicílio. Dirceu disse que o repórter tentou se passar por um assessor para entrar no quarto ${ }^{13}$.

Sobre isso, Veja afirma na matéria que o nome de Dirceu não constava na lista de hóspedes do hotel e que isso precisava ser investigado, conforme abaixo.

"O jornalista esteve mesmo no hotel investigando, tentando descobrir que atração é essa que um homem acusado de chefiar uma quadrilha de vigaristas ainda exerce sobre tantas autoridades (...) Enfim, tentando mostrar a verdade sobre as atividades de um personagem que age sempre nas

13 http://noticias.terra.com.br/brasil/politica/ze-dirceu-acusa-veja-de-invadir-seu-apartamento-embrasilia,3efccc00a90ea310VgnCLD200000bbcceb0aRCRD.html 
sombras. Mas a máfia não perdoa” (p.80).

\section{Considerações sobre a matéria em análise}

A seguir, reunimos os principais dados elencados pela revista que corroborariam a conclusão de que as reuniões seriam conspiratórias:

- As reuniões foram realizadas em curto espaço de tempo (três dias seguidos) e no mesmo lugar

- As reuniões ocorreram às vésperas da demissão de Palocci

- Alguns visitantes eram adversários internos de Dirceu dentro do PT, teriam interesses por cargos. Porém Dilma indica outros nomes e Veja demonstra simpatia pela decisão da presidente

- Depois da cassação, Dirceu se tornou consultor de grandes empresas. Teria interesses financeiros em relação às mudanças de cargos.

Além disso, observamos que a revista explora algumas semelhanças da narrativa sobre Dirceu com a narrativa de "O poderoso chefão". Por exemplo, quanto às características do personagem Don Corleone:

- Gosta que lhe chamem de padrinho/"Ainda é chamado de ministro" (p.74)

- As pessoas beijam as mãos e o rosto dele/ "Dirceu tenta recuperar o prestígio político que tinha no governo Lula, usando como arma os muitos aliados que ainda lhe beijam o rosto" (p.75).

- Exige lealdade

- As cenas de reuniões são em locais escuros, escondidos/"mantém um concorrido gabinete num quarto de hotel, tem carro à disposição, motorista, secretário" (p.74)

- Tenta ser conciliador de interesses com adversários/"Um cacique petista tenta explicar a união recente de Pimentel com José Dirceu: 'No PT, é comum adversários num determinado instante se aliarem mais à frente para atingir um objetivo comum"”

- Está sempre em reunião com aliados e é influente/ "Sua agenda sempre está recheada de audiências com próceres da República” (p.75).

- Tentam tirar-lhe o poder mas ele consegue mantê-lo/"O chefe ainda é poderoso (...) oficialmente, ele ganha a vida como um bem sucedido consultor de empresas instalado em São Paulo. Mas é em Brasília que ele continua a exercer seu principal talento" (p.74).

\section{- Funções}

O ex-presidente Lula deixou danos que precisam ser corrigidos. A heroína é Dilma, que está corrigindo os danos. Veja se mostra aliada e, por meio da matéria sobre as reuniões de Dirceu, tenta alertar a presidente do perigo que o ex-ministro representa.

Veja também se coloca como heroína ao relatar que estaria sendo perseguida por investigar Dirceu, que age nas sombras. Coube a ela mostrar quem é o vilão da história, revelá-lo. 
Dirceu se mantém como anti-herói trágico. A narrativa não revela boas ações e intenções em seus atos. Fala sobre seu passado, mas o desconstrói imediatamente.

\section{5) Edição 2280 - $1^{\circ}$ de agosto de 2012}

Capa: Réu - O petista José Dirceu e mais 37 acusados no caso do mensalão começam a ter seu destino decidido nesta semana no "julgamento do século" no Supremo Tribunal Federal - STF em Brasília

Chamada na linha superior da capa: Os planos A,B,C de Dirceu - o " $D$ " era fugir do Brasil: "sair clandestino de novo não custa nada"

Chamada da matéria: Destemido e temido. Frio, impiedoso e agora no banco dos réus - O Lado Escuro: a enigmática personalidade de José Dirceu, as incríveis histórias de sua vida e os três destinos que o principal réu do mensalão traçou para si para depois do julgamento que começa esta semana

Resumo: a matéria faz uma retrospectiva histórica de momentos da vida de Dirceu em que ele despertou suspeita, inclusive no treinamento em Cuba durante o seu exílio. Dessa forma, especula as possibilidades traçadas por Dirceu em relação ao julgamento do mensalão, entre elas fugir do país e se tornar clandestino de novo. Traça um perfil emocional de Dirceu: que estaria insatisfeito por seu projeto político ter dado errado e compensa o fim da carreira política ganhando dinheiro com negócios escusos.

\section{Análise}

Capa: em fundo preto, a revista traz uma foto de Dirceu com o semblante aparentemente preocupado e logo abaixo o título "Réu" com a fonte em caixa alta e vermelha. Observou- se que a aparência de Dirceu na capa é semelhante à imagem do personagem Don Vito Corleone, interpretado por Marlon Brando, em uma das cenas do filme "O Poderoso Chefão".

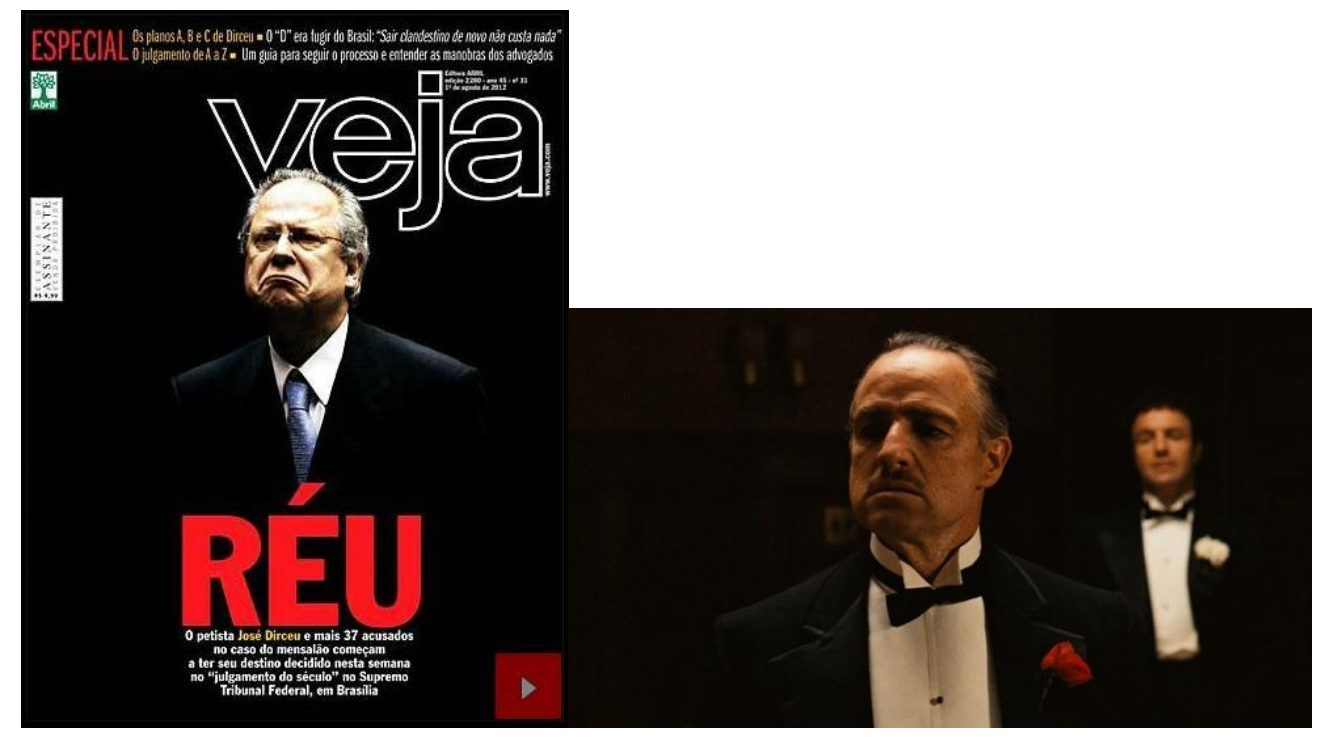




\section{Figura 2: José Dirceu e Don Corleone: o destaque são as expressões faciais}

Foto Principal: As fotos com close no rosto do personagem, remetem à chamada principal, pois a luz está apenas do lado direito. O lado esquerdo acompanha o fundo preto das duas primeiras páginas do texto. O termo "Lado Escuro" evidencia várias características que foram elencadas em no levantamento teórico. É uma metáfora visual com alusão à desconfiança na política e nos políticos. Pressupõe-se que José Dirceu tem um lado escuro, ou seja, escondido, que deve ser investigado e publicado: "a enigmática personalidade de José Dirceu, as incríveis histórias da sua vida e os três destinos que o principal réu do Mensalão traçou para si para depois do julgamento que começa esta semana" (Veja, 2012, p.67).

Recursos Gráficos: Na página 68, há uma foto desfocada de Roberto Jefferson com José Dirceu ao fundo. Na legenda, a revista explica que a imagem se refere ao depoimento do ex-chefe da Casa Civil no Conselho de Ética da Câmara dos Deputados em 2005. Como foi considerado o "delator" do esquema, as narrativas jornalísticas sobre o "Mensalão" destacam Jefferson como o antagonista de José Dirceu, o que evidencia o conflito como categoria estruturante da narrativa política.

Narrativa: O acontecimento-intriga é o início do julgamento do "Mensalão" no Supremo Tribunal Federal - STF e o núcleo narrativo é o protagonismo de José Dirceu no julgamento. O enredo é não-linear e o tempo não-cronológico. A revista inicia o texto contando um episódio que teria acontecido com Dirceu nos anos 60. A matéria analisada é distribuída em quatro páginas e abre uma série de reportagens sobre as expectativas do julgamento, as possibilidades de votos dos ministros do STF, cronologia do caso, perfil dos réus e dos advogados.

É sabido que o enredo integral sobre o escândalo do "Mensalão" não se resume ao protagonismo de José Dirceu. Envolvem outros fatos que se interligam, elementos, antagonistas e coadjuvantes, elementos comuns a qualquer narrativa. Mas na matéria analisada, Veja conta a história do Mensalão a partir da ótica do personagem.

A revista especula os planos de Dirceu em todos os cenários possíveis de condenação para traçar como seria a sua vida e anseios após o julgamento da AP-470, planos e até a participação em episódios relatados por fontes não reveladas, aqui também consideradas como narradores que os teriam presenciado.

Espaço Predominante: Locais privados como restaurantes, apartamentos e escritórios frequentados por Dirceu e por interlocutores.

Ambiente: o ambiente é de tensão e incertezas em torno do início do julgamento.

Narrador Principal: é o repórter Otávio Cabral que um ano depois lançou uma biografia sobre José Dirceu. É onisciente, ou seja, mesmo não tendo presenciado os fatos, ele teria conhecimento sobre eles por meio de suas fontes e intruso, pois manifesta opiniões, juízos de valor e posicionamentos políticos da revista.

\section{Personagens: José Dirceu (Proganonista)}

O adjetivo "principal réu" que está na chamada da matéria remete à categorização de José Dirceu como personagem e protagonista da narrativa sobre o julgamento do Mensalão, também demonstrado com a atribuição dada pela revista ao ex-ministro como "chefe de quadrilha", uma das acusações para qual foi julgado pelo STF, de ter sido mentor do esquema do Mensalão.

Portanto, para iniciar a leitura da matéria propriamente dita, o destinatário se depara com várias chamadas e um texto de abertura, então, é possível afirmar que a revista já traz a caracterização psicológica do personagem como forma de incentivar a continuação da leitura: "Destemido e temido. Frio, impiedoso e agora no banco nos réus" (Veja, 2012, p.67). 
Momentos de intimidade do ex-ministro, no passado e em situações recentes, são relatados com riqueza de detalhes - pressupõe-se que foi testemunhado por fontes - mas a estrutura do texto é narrativo.

A revista diz em qual espaço físico aconteceu uma conversa, além de atribuir juízo de valor ao ambiente (restaurante tradicional no bairro dos Jardins, que remete a ideia do local ser reservado, ou seja, freqüentado por pessoas públicas ou de alto poder aquisitivo); os personagens que estavam no local (José Dirceu e o ex-presidente Lula); as falas dos dois por meio de discurso indireto (no caso da narrativa jornalística, sem aspas) e a reação e o pensamento conclusivo de Dirceu diante das afirmações atribuídas a Lula (descrição psicológica do personagem).

Em um tradicionalíssimo (restaurante) português dos Jardins (José Dirceu) ouviu de Lula a sugestão de transferir seu domicílio eleitoral para o Distrito Federal e disputar por lá o cargo de governador ou senador. Gostou muito. Governador do Distrito Federal dá mais relevância do que deputado federal por São Paulo (Veja, 2012, p.68).

Fazendo uso do discurso direto, a revista também atribui falas ao ex-ministro e a outros personagens (o ex-presidente Lula é um deles) com o recurso das aspas, quando os fatos aconteceram e quais testemunhas estavam presentes. No trecho abaixo, observamos não só as aspas, mas novamente a descrição de um ambiente reservado e dos sentimentos do personagem José Dirceu diante da possibilidade de ser preso após o julgamento do Mensalão.

O pavor da prisão fez com que, há dois meses, ele chegasse a pensar em fugir do Brasil. "Para quem já viveu o que eu vivi, sair daqui clandestino de novo, não me custa nada", disse em um jantar na casa do advogado Ernesto Tzirulnik, em São Paulo, na presença de uma dezena de convidados, entre eles, o ministro da Justiça José Eduardo Cardoso (Veja, 2012, p.68)

Já na citação a seguir abaixo, observa-se um dos pontos destacados na matéria, o mistério em torno da amizade entre José Dirceu e Lula após o escândalo do Mensalão. José Dirceu foi demitido do cargo de ministro chefe da Casa Civil em 2005 e, desde então, percebe-se um afastamento público entre os dois.

[José Dirceu] veio para São Paulo e ajudou a fundar o PT no qual desenvolveu com Lula uma relação sianesa e tensa também. Embora até hoje se falem todos os dias, ambos concordam que não são amigos - o "Zé não é amigo de ninguém”, diz Lula (Veja, 2012, p. 70).

De acordo com os fatos relatados pela matéria, José Dirceu se ressente de ter perdido a possibilidade de ascender no poder, no caso descrito no texto, a Presidência da República, por causa do escândalo do "Mensalão". Pode-se dizer que esse é um ponto de virada na trajetória do personagem que mudou o rumo do que poderia estar sendo planejado por ele no campo político.

Para Veja, Dirceu, mesmo com o seu legado histórico de combatente da Ditadura Militar e líder influente no PT, detentor de poder como ministro da Casa Civil, se tornou um político corrupto e, após o escândalo do Mensalão, uma figura decadente.

A partir da descrição de fatos históricos que envolveram Dirceu e construíram em torno dele um imaginário heroico, é evidente, na matéria analisada, a intenção de Veja em persuadir o leitor a quebrar esse imaginário e, principalmente, desqualificar Dirceu como alguém, que muito antes do Mensalão, já despertava suspeita.

Em 1970, ele era o $13^{\circ}$ elemento na Casa Brasil em Havana, alojamento preparado por Fidel Castro para receber e treinar guerrilheiros exilados ou fugitivos do Brasil. Os outros doze desconfiavam que Dirceu fosse agente de Fidel infiltrado entre eles. Só ocasionalmente ele dormia na Casa Brasil. Dormia mal. A suspeita foi ganhando corpo. Em um exercício noturno de sobrevivência no mar, alguns camaradas tentaram afogá-lo. (VEJA, 2012, p.67) 
Portanto, é possível afirmar que a função do personagem na matéria analisada é a de anti-herói trágico, pois a revista ressalta vários aspectos negativos sobre ele nas descrições psicológicas e nos episódios relatados na matéria em que ele está envolvido. No Quadro 4, está uma lista dos adjetivos e ações atribuídos na matéria analisada a Dirceu, nenhum deles evidencia qualquer evolução do personagem.

Quadro 4: Adjetivos e ações atribuídos a Dirceu

\begin{tabular}{|l|c|c|}
\hline Personagem & Adjetivos & Ações atribuídas ao personagem e descrições psicológicas \\
\hline José Dirceu & Misterioso & Alterna momentos de glória com momentos obscuros \\
\hline & Rico & Consultor de contratos sigilosos e vultuosos \\
\hline & Chefe de Quadrilha & Principal réu do Mensalão \\
\hline & Símbolo do Mensalão & Estará sob os holofotes durante o julgamento \\
\hline & Rejeitado & Tem medo de vaias \\
\hline & Decadente & Quer voltar para a política em caso de absolvição \\
\hline & Destemido & Pensa em fugir do país \\
\hline & Frustrado & Quer ganhar muito dinheiro se não voltar à política \\
\hline & Frio ve fortalece e foca a mente em momentos de crise \\
\hline & Realista & Se condenado, acha que nunca mais voltará à política \\
\hline & Não tem amigos & Possui uma relação siamesa e tensa com Lula \\
\hline & Passou o rolo compressor nas tendências radicais do PT \\
\hline
\end{tabular}

José Dirceu foi condenado pelo STF por dois crimes (formação de quadrilha e corrupção ativa), em 2012, mas as especulações sobre o destino do personagem, apontado pela revista na edição analisada, caso isso ocorresse, não se realizaram.

O plano B leva em conta o pior cenário: a condenação com pena alta - e cadeia. Nesse caso, Dirceu já definiu o seu projeto: vai virar mártir. Desmontará sua consultoria e voltará para os braços do PT radical. Cogita até mesmo denunciar o estado brasileiro a cortes internacionais de direitos humanos. (VEJA, 2012, p.68)

Como foi observado na matéria analisada, não há no texto nenhuma referência de que José Dirceu foi entrevistado pela reportagem para dar sua versão da história e nem se foi procurado pela revista para esse objetivo. A ele são atribuídas falas, pensamentos e outras informações ditas por fontes não reveladas.

\section{Considerações sobre a matéria em análise:}


- Foi identificada a utilização do encadeamento, elemento estruturante da narrativa caracterizado pela presença de uma história seguida da outra sobre um enredo central, como proposto por Todorov (1971). A presente análise se concentra nos adjetivos e ações atribuídos a José Dirceu para investigar suas funções de personagem.

- Na visão de Motta (2013), as aspas e diálogos detalhados são estratégias argumentativas da narrativa jornalística para, ao garantir a exatidão do texto, ganhar a credibilidade do destinatário.

- Esses acontecimentos descritos pela matéria são pano de fundo para a dramatização midiática de um incidente destruidor para um personagem que protagonizou um escândalo político dentro uma estrutura seqüencial elaborada por Thompson (2002).

- A partir das observações de outras matérias de Veja que serão analisadas e com base nos estudos de Campbell (1997) sobre o ciclo do herói, observamos que há um interesses nas narrativas da revista sobre o José Dirceu, após o escândalo do Mensalão, de fazer referência ao passado do exministro quando era líder estudantil em 1968 e sobre o que fez durante o exílio e clandestinidade durante a Ditadura Militar.

\section{6) Edição 2325 - 12 de junho de 2013}

Capa: A verdade sobre José Dirceu - uma biografia não autorizada contra a transformação do jovem militante em um exímio manipulador político, homem de negócio e condenado que sequestrou, teve múltiplas identidades, chantageou Lula

Chamada da matéria: Todas as caras de Dirceu - na mais completa e surpreendente biografia do petista, as aventuras, traições, amores e tramoias do líder estudantil bonitão e mulherengo que virou o segundo homem mais poderoso da República e agora se encontra a caminho da prisão

Resumo: é uma resenha do livro de Otávio Cabral "Dirceu, a biografia" e traz os trechos mais marcantes do livro a respeito da vida do ex-ministro: do movimento estudantil ao governo Lula, ele seria alguém que gosta de poder e de usufrui-lo. Destaca situações da vida pessoal, os seus casamentos, crimes que ele teria cometido na Ditadura, a clandestinidade, a relação com Lula e situações de bastidores ocorridas durante a explosão das denúncias do Mensalão em 2005. A matéria deixa claro que tudo que Dirceu fez não foi por um ideal e sim para satisfazer suas vontades.

\section{Análise}

Capa: É consolidação de como Veja construiu o personagem José Dirceu desde o início da vida pública do ex-ministro que começou no movimento estudantil. Ao jogo de cores claro-escuro ao fundo (um bege que se torna marrom), observada em outras edições, foi acrescentada uma máscara da imagem de José Dirceu jovem, na época da Ditadura, que é tirada por ele próprio a partir de uma montagem de imagens. Por baixo da máscara, está o José Dirceu mais atual, político e de paletó e gravata.

Foto principal: como se trata de uma matéria sobre a biografia de Dirceu, a foto principal é uma montagem de fotos do personagem em cada fase da sua vida. A primeira da esquerda pra direita, mostra um Dirceu jovem com o olhar seguro e sorridente. A última da direita para a esquerda mostra um Dirceu abatido e envelhecido. Só pela montagem das fotos é possível identificar o ciclo vivido por Dirceu desde a juventude. Do passado heróico de militante, a um político fracassado e condenado por corrupção. As primeiras duas páginas também trazem uma foto de 
Otávio Cabral, pequena abaixo da chamada "Todas as caras de Dirceu".

Recursos Gráficos: mesclam o texto da matéria com fotos e trechos do livro referentes aos assuntos destacados: "o sequestrador" (p.65), "o protegido de fidel" (p.65), "Pedro Caroço" (p.67), "melhor inimigo de Lula" (p.67), "o ministro e os deslumbrados" (p.68), "o início do fim" (p.69).

As páginas seguem um padrão gráfico, aos fundo, remontam a papel amassado ou rasgado. Se relacionarmos a Dirceu, podemos dizer que o rasgado representa ruptura e o amassado, um passado que não possui mais serventia.

Narrativa: não há acontecimento intriga, nem núcleo narrativo. A matéria é uma resenha do livro de Otávio Cabral e reúne vários fatos negativos sobre a vida de Dirceu, que Veja chama de "verdades". O enredo é não linear: a história começa com a posse de Dirceu como ministro-chefe da Casa Civil em 2003 para então traçar um resumo da biografia dele do passado (começando pela infância) ao presente.

Otávio Cabral foi editor de Veja, então grande parte do que está nas páginas da revista sobre Dirceu desde 68 é utilizada pelo autor. Porém, a biografia não mostra apenas o lado ruim de Dirceu. A obra expõe o que teriam sido conflitos de consciência do personagem, suas frustrações amorosas, sua relação com os filhos e outros dramas.

Mas, para a matéria, a revista seleciona os fatos negativos, os mistura de forma que o leitor possa concluir que se Dirceu sequestrou e criou outra identidade para voltar clandestino ao Brasil, é capaz de qualquer outra coisa. $\mathrm{O}$ sequestro e posteriormente a clandestinidade foram consequências dos confrontos entre grupos de direita e de esquerda na Ditadura Militar, um outro momento histórico, diferente do que seria a vida atual do ex-ministro.

Espaço predominante: Não há espaço predominante. Vários são elencados para localizar os fatos relacionados ao personagem. Passa Quatro (terra natal de Dirceu), São Paulo (onde Dirceu começou no movimento estudantil), Cuba (onde Dirceu se exilou), Cruzeiro do Oeste (onde Dirceu morou durante o período da clandestinidade) e Brasília (onde Dirceu exerceu seus mandatos de deputado e de ministro).

Ambiente: é de permanente desconfiança em relação ao protagonista. É predominante a construção negativa do passado, presente e futuro de José Dirceu.

\section{Personagens}

José Dirceu é o protagonista da matéria que gira em torno do lançamento do livro de Otávio Cabral. No contexto narrativo, o personagem e o jornalista são colocados em lados opostos. O papel de investigador é de Cabral que afirma ter entrevistado 63 pessoas e lido mais de 15 mil páginas de documentos durante a pesquisa que realizou para escrever a biografia do ex-ministro. Esses dados são ressaltados na matéria como garantia de credibilidade do autor. $\mathrm{O}$ fato de ser editor da revista também complementa essa ideia.

Para Veja, Dirceu é revelado no livro "na forma de decisões imperiais, arroubos de grandeza e também viagens em jatinhos e noitadas com belas mulheres - o imenso apreço de Dirceu pelo poder e tudo que dele decorre" (p.63). A revista também considera a obra como "a mais completa e surpreendente biografia [de José Dirceu]" (p.64).

Na chamada da capa, a revista afirma que a biografia traz "a verdade sobre José Dirceu" e resume o 
que seria o universo de caracterização relacionado à vida dele: Ditadura, política, queda e a condenação pelo STF. Todo esse ciclo, construído pela revista de forma espaçada, foi reunido no livro de Otávio Cabral, que foi editor de Veja, cobriu o escândalo do mensalão e está entre os narradores principais das edições analisadas. "'Dirceu - a biografia' conta essa e outras histórias definidoras da personalidade do biografado" (p.63)

Ao longo das análises anteriores, foi observado que Veja faz associações da vida pessoal de Dirceu e de seu passado, da Ditadura até a Anistia, com o que seriam atitudes atuais dele. O personagem é inserido na narrativa da revista como alguém que nunca mediu esforços para ter o que quer: poder, mulheres e dinheiro. Isso é observado pelos verbos de ação atribuídos a Dirceu: "sequestrou", "teve múltiplas identidades", "chantageou Lula".

No período em que o livro foi lançado, Dirceu já tinha sido condenado pelo STF por corrupção ativa e formação de quadrilha no julgamento do Mensalão. Ele estava esperando a votação de recursos e ainda não tinha sido preso.

Predominam na matéria as características sociais e psicológicas de Dirceu. O texto começa relatando que o primeiro ato de Dirceu como ministro-chefe da Casa Civil já era um indício de sua busca pelo poder individual. O livro traz a informação de que, até Dirceu ser empossado, o primeiro a seguir o presidente durante cerimônias oficiais era o ministro da Justiça. "Dirceu transferiu a prerrogativa para si: quem apareceria caminhando logo atrás do presidente seria ele, o chefe da Casa Civil" (p.63).

Os principais pontos considerados essenciais por Veja na caracterização de Dirceu constam no livro e ficam evidentes da matéria que organiza as informações sob uma ótica biográfica. Para a revista, tanto Dirceu, quanto Lula possuem "biografias extraordinárias" e "prometiam mudar o Brasil" (p.63).

Antes de chegar aos trechos do livro selecionados para a matéria, a revista resume o que entende como traços de personalidade de Dirceu, que constam na biografia, manifestados desde o seu período como líder estudantil. "Narra sua mudança para São Paulo e os primeiros envolvimentos com a política e as mulheres, duas paixões que o dominariam ora como obsessão, ora como problema" (p.64).

Ao detalhar episódios da infância do biografado em Passa Quarto, a revista destaca o trecho do livro que o descreve como "terror da vizinhança e contumaz torturador de gatos" (p.64).

A matéria cita três mulheres que fizeram parte da vida de Dirceu. Iara Iavenberg, militante de esquerda que teve um relacionamento com ele antes de ir pra luta armada; Heloísa Helena Magalhães, a espiã da Ditadura que teria "seduzido" Dirceu, conhecida pelo codinome de "Maçã Dourada" e Clara Becker, com quem se casou no período da clandestinidade. "Três dos seus quatro casamentos terminaram com uma traição (da parte dele). Dois de seus quatro filhos foram concebidos fora das cobertas conjugais" (p.64).

É recorrente nas matérias de Veja em que José Dirceu é protagonista uma espécie de julgamento moral relacionado a sua vida afetiva. A história com Clara Becker, por exemplo, é mais citada na narrativa da revista para justificar o pragmatismo de Dirceu na política e seu suposto gosto pela "traição" e "chantagens". 
A atuação de Dirceu como militante de esquerda e de líder estudantil na Ditadura Militar também é usada como justificativa para a personalidade do biografado, algo que Veja destaca na matéria pela seleção de dois episódios ocorridos durante o regime militar que teria tido o envolvimento do personagem: o sequestro do estudante João Parisi, que fazia parte do Comando de Caça aos Comunistas - CCC em 1968 e o assassinato de um sargento da Polícia Militar de São Paulo em 1972.

Otávio Cabral afirma que essas informações seriam inéditas. Percebe-se então a intencionalidade da revista em publicar esses trechos. Como observado em outras edições, a revista procura divulgar possíveis fatos que teriam acontecido nesse período para contradizer e desconstruir o imaginário de herói da esquerda atribuído a Dirceu principalmente pelos militantes do PT. "O norte moral de José Dirceu sempre foi regido por outra bússola" (p.64).

Outra característica psicológica presente nas matérias de Veja, uma das principais levadas em consideração por Otávio Cabral no livro, é o pragmatismo de Dirceu para alcançar o poder e mantê-lo. A matéria fala sobre a relação do protagonista com o ex-presidente Lula e a importância dos dois na condução que levou o PT a conquistar a Presidência da República.

Porém, Dirceu e Lula teriam funções diferentes nesse processo, como se observa abaixo.

"Nesse arranjo cabia a Lula brilhar no palanque, enquanto Dirceu fazia o serviço pesado - e sujo quando preciso (...) "a relação [ entre Lula e Dirceu] nunca foi um passeio no campo e incluiu até chantagem" (...) "um jamais confiou interinamente no outro" (p.68).

A principal caracterização ideológica e social que Veja atribui ao personagem, que também aparece em edições já analisadas, é que Dirceu se apresenta como um político de esquerda, mas não é. Para a revista, ele se utilizou dessa ideia para alcançar poder no PT, posteriormente a Presidência da República. Mas uma vez, a revista cita situações relacionadas a vida pessoal do ex-ministro para justificar a relevância e crédito dessa informação quando salienta que Iara Iavemberg teria dito a uma amiga que Dirceu não teria dotes intelectuais. "Dirceu não perde tempo com ideologias. Trama, conspira, dissimula, confronta" (p.68).

O termo anti-herói como definidor da função de José Dirceu na biografia é citado pela primeira vez em um matéria que integra o corpus da análise. Veja também complementa que o projeto de poder individual de Dirceu fracassou, o que já tinha sido especulado pela revista no período em que o escândalo do Mensalão eclodiu e ele foi demitido do cargo de ministro-chefe da Casa Civil e teve o mandato de deputado federal cassado. Essa conclusão faz parte da análise da edição "Réu", que traz a expectativa para o julgamento no STF:

"Parece irrecorrivelmente perdido o projeto de poder pessoal, a única causa pela qual genuinamente lutou. 'Dirceu' é uma reportagem magistral sobre a vida de um anti-herói sem escrúpulos" (p.68).

\section{7) Edição 2348 - 20 de novembro de 2013}

Capa: Uma lição aos corruptos - o Supremo Tribunal Federal - STF decreta a prisão dos condenados no maior escândalo de corrupção da história

Chamada da matéria: A quadrilha na cadeia - oito anos e seis meses depois de revelado, o escândalo do mensalão leva a prisão os chefões do PT, deputados, ex-deputados e empresários 
envolvidos no maior caso de corrupção da história recente

Resumo: matéria faz um panorama sobre os condenados no processo do mensalão que serão presos, com destaque para os "chefões do PT": José Dirceu, José Genoíno e Delúbio Soares. Trata também dos recursos impetrados para protelar a execução penal, que os condenados não acreditavam que seriam presos e quais as penitenciárias para onde deviam ir. Sobre Dirceu, o destaque fica para a mudança radical de vida que o ex-ministro passará - "acostumado com luxo" - indo para a prisão.

Capa: claro e escuro novamente. Um lado do rosto claro e outro escuro. A luz vem através das grades que refletem no rosto de Genoíno, Dirceu (cujo a imagem tem mais destaque, ao meio, até pela função que exerce no caso - chefe) e Delúbio Soares. Fundo marrom para dar destaque às fotos e à luz. Foram 25 condenados, mas revista opta por associar o mensalão aos condenados e protagonistas do núcleo politico do esquema. Quando o escândalo foi revelado, Dirceu era ministro, Genoíno presidente do PT e Delúbio o tesoureiro da legenda.

Foto Principal: Os mesmos personagens da capa. Dirceu é o primeiro da esquerda pra direita, com maior destaque - a foto parece maior que as de Delúbio Soares, que está de cabeça baixa, e a de Genoíno. As fotos principais são diferentes das fotos de capa.

Recursos Gráficos: fotos dos outros condenados citados na matéria, de ministros do STF e do plenário da Corte. Uma cronologia sobre o caso, desde a matéria de Veja sobre a propina nos Correios até o decreto emitido pelo STF para execução penal. Duas boxes. Uma sobre um processo de 2007 que tramita no Supremo contra o ex-presidente Fernando Collor de Melo. E a outra com uma entrevista com o juiz Ademar da Silva Vasconcelos, da Vara de Execução Penal do DF, gestor do processo de prisão dos condenados.

Narrador principal: é o repórter Daniel Pereira, junto com Hugo Marques e Adriano Ceolim. Onisciente e intruso.

Narrativa: o acontecimento-intriga é o julgamento do Mensalão e o núcleo narrativo é a execução penal. O enredo é não-linear, mescla informações atuais e passado recente. José Dirceu, condenado em 2012 por formação de quadrilha e corrupção ativa, foi preso no dia 15 de novembro, assim como outros condenados. A matéria repercute o fato, relata situações de bastidores. O foco é a ideia de que, diferente de outras ocasiões, políticos e empresário foram julgados, condenados e presos no Brasil. O texto conduz o leitor a concentrar a expectativa de combate à corrupção ao STF mais precisamente ao então presidente da corte, relator do Ação Penal 470, Joaquim Barbosa.

A matéria personifica as instituições Imprensa, Ministério Público Federal e STF. Esses órgãos teriam conseguido derrubar o que Veja considera como falácias do PT divulgadas com o objetivo de provocar esquecimento do escândalo do Mensalão. Veja também atribuiu perseguição do PT aos órgãos em nome disso, porém, na visão da revista, não o partido não teria conseguido o que queria:

"Caixa dois eleitoral. Piada de salão. Golpe da elite contra o governo do povo. Durante mais de oito anos, petistas estrelados entoaram esses mantras" (p.61)

Ao personalizar instituições e definir um antagonista para elas (no caso, o PT), Veja as torna heroínas do escândalo do Mensalão. Imprensa, MPF e STF corrigiram não só os danos relacionados ao caso, mas também combateram a ideia de que o Brasil é o país da impunidade, de uma Justiça que não manda prender político e empresário: 
"Anunciadas as condenações de 25 réus em dezembro do ano passado, restou aos mensaleiros pressionar - por meio de seu esquadrão milionário de advogados renomados - pelo adiamento da execução das penas (...) esta última cartada parecia fadada ao sucesso. Afinal de contas, a cadeia no Brasil não é lugar para políticos e empresários" (p.61).

Em novembro de 2013, o STF decretou a prisão de alguns condenados, entre eles, José Dirceu, mesmo sem que recursos ingressados pelos réus fossem analisados. Veja deu destaque à informação:

"Na semana passada, no entanto, o STF deu um basta às chicanas e mostrou que está mesmo disposto a devolver aos cidadãos de bem a confiança no Poder Judicário" (p.62).

Nesse momento, Veja traça mais um perfil de José Dirceu. Dessa vez, o personagem já é condenado e agora preso. "Mais de um adezena de mensaleiros começará já a expiar seus pecados na prisão" (p.62).

O uso da expressão "cidadãos de bem" é outro indício da personalização do heroísmo do STF, representado principalmente por Joaquim Barbosa, apesar de Veja citar outros ministros. A matéria faz a separação do bem (STF) contra o mal (PT/Mensaleiros). E quando utiliza a palavra "pecados", comum nos discursos religiosos, decreta seu posicionamento sobre os condenados de que precisam não só pagar o que devem a Justiça, mas também precisam sofrer. O pagamento de pecados está relacionado, no universo de algumas religiões, ao sacrifício e ao sofrimento, em nome da purificação da alma.

\section{José Dirceu}

O personagem ocupa um espaço menor na matéria em comparação às anteriormente analisadas, mas continua sendo um dos protagonistas da narrativa de Veja sobre o escândalo e o julgamento do Mensalão. Novamente, a informação de que Dirceu está preso é destacada.

"Em menos de uma década, Dirceu trocou o Palácio do Planalto pelo Congresso, teve o mandato de deputado cassado e, agora, passará uma temporada atrás das grades" (p.62).

O ciclo destrutivo de Dirceu apresentado por Veja na matéria é um resumo da trajetória do exministro após a eclosão do escândalo em 2005. A função de anti-herói trágico se mantém. "[A prisão] é uma mudança e tanto para quem desfilava por Brasília como o todo-poderoso da República" (p.62).

Descrever a frustração de Dirceu por não ter concretizado seu projeto pessoal de poder, também é recorrente como descrição psicológica do personagem em Veja:

"Dirceu, por exemplo, tinha a certeza de que, depois dos mandatos de Lula, seria presidente da República" (p.62).

A expectativa de um apoio que viria de Lula para que Dirceu se livrasse da prisão também integra essa descrição psicológica. As afirmativas da revista de que existe antagonismo na relação entre Dirceu e Lula - inclusive quando trabalhavam juntos no PT e no governo - também reaparece. Dessa vez, a visão de Dirceu apontada pela revista é do anti-herói trágico que não encontra mais aliados fortes para tirá-lo do ciclo destrutivo. A matéria cita Lula e também a presidente Dilma Rousseff entre aqueles que Dirceu considera que o abandonaram. Estes aspectos podem ser identificados nos trechos a seguir:

"Até a véspera do início do julgamento, em agosto de 2012, ele [Dirceu] ainda acreditava na promessa de Lula de desmontar a 'farsa do mensalão' e ajudar a absolver os companheiros 
acusados no processo" (p.62).

Veja cita também o desapontamento de Dirceu de ter sido excluído da chapa do diretório do PT "sem ser consultado" (p.62).

"A amigos garante que só soube [da exclusão da chapa] pelos jornais. O petista pragmático reclamou do pragmatismo dos antigos companheiros" (p.62).

A revista considera que mesmo sem ter o apoio que desejava de Lula, Dilma e de outros nomes fortes do PT, Dirceu ainda parecia imaginar que não seria preso mas, novamente teria se frustrado. $\mathrm{O}$ fato de o ex-ministro estar num resort com a família, na Bahia, às vésperas da execução penal seria uma das evidências que a revista traz para continuar compondo a descrição psicológica do personagem:

"Parecia ainda nutrir a crença de que a cadeia era apenas uma miragem. Mas só parecia. A crença na impunidade já tinha dado lugar à expectativa de expiação dos pecados" (p.62).

A possível aceitação da possibilidade de ser preso mostra Dirceu como um personagem resiliente e frio. A frieza e o pragmatismo atribuídos pela revista a ele são características reforçadas também em outras edições, inclusive, anteriores ao mensalão.

\section{Descrição dos Presídios}

Após atribuir a José Dirceu quais seriam suas reações enquanto ele esperava ser preso, Veja faz a descrição físicas dos presídios e celas para onde os condenados iriam cumprir pena.

Além do ministro, a revista destaca outros condenados: João Paulo Cunha, Pedro Henry, Waldemar Costa Neto, Roberto Jefferson, Marcos Valério, Katie Rabello e Henrique Pizzolato.

A matéria traz a descrição física detalhada de uma ala especial do Presídio Pedrolino Oliveira, conhecida como Bangu 8, no Rio de Janeiro, para onde iriam Roberto Jefferson e Henrique Pizzolato:

"A ala especial é composta de um grande galpão com treliches, um banheiro com três chuveiros e três vasos sanitários. Acomoda anualmente cerca de trinta pessoas, o que não configura superlotação" (p.64).

Segundo a revista, os presos podem ter uma TV de 14 polegadas, ventilador e receber comida de casa:

"Eles [presos] passam o dia na cela comum ou num pátio aberto, com campo de futebol e aparelhos de musculação. Depois de três meses de reclusão podem trabalhar na faxina ou na administração" (p.64).

Para divulgar mais informações sobre como seria o espaço no Complexo Penitenciário da Papuda, no Distrito Federal, onde uma parte dos condenados ficaria, Veja entrevistou o juiz Ademar da Silva Vasconcelos.

Entre os condenados estava José Dirceu, que após a execução penal foi transferido de São Paulo para Brasília. Para isso, a revista destacou a entrevista do juiz em um boxe.

Nas perguntas, o repórter Hugo Marques manifesta o interesse da revista em saber se os condenados teriam privilégios na prisão. Essa ideia começou a ser construída no início da matéria quando Veja compara as penas a "pecados". 
Se pagar pecados denota sacrifícios, não parecia ser justo para a revista que os condenados tivessem qualquer mais conforto ou privilégio em relação aos presos "comuns":

"Em setembro passado, o governo do Distrito Federal, comandado pelo petista Agnelo Queiroz, aproveitou uma reforma prevista no cronograma de obras do Presídio de Brasília para, na surdina, construir quatro celas individuais com banheiro, janela e instalações para receber chuveiro elétrico e ar condicionado" (p.68).

$\mathrm{Na}$ entrevista, o juiz nega que os presos ficariam nos locais descritos no texto de abertura da entrevista. Porém, seriam alocados a celas individuais para evitar conflito com os demais presos, por questões de segurança. Segundo ele, celas individuais para ex-deputados, ex-promotores, expoliciais estão previstas em lei:

"Essa ameaça não acaba gerando um privilégio para os mensaleiros? [resposta de Ademar Silva Vasconcelos] $O$ sistema não permite privilégios. O sistema penal tem uma dimensão que não particulariza as pessoas (...) não há estrutura pra isso" (p.68).

O repórter, porém, insiste em basear suas perguntas com a ideia de que, se há diferença no cumprimento da pena dos condenados pelo Mensalão em comparação com outros detentos, ou seja, se os "mensaleiros" não sofrerem com as limitações do sistema penal, isso não fará efeito para o fim da impunidade. Até o fato de alguns deles terem sido condenados ao regime semi-aberto parece não ser suficiente para o ideal castigo que revista deseja para os seus vilões. Para justificar isso, Veja afirma em outras edições que é um "desejo dos brasileiros" como será explicado mais adiante.

A resposta de Ademar Vasconcelos confirma que a revista quer exercer o papel de heroína disposta a ultrapassar limites legais para destruir o inimigo:

"Condenar corruptos ao cumprimento de pena em regime semiaberto não parece leniência? [resposta de Ademar Silva Vasconcelos] a pena não pode ser vingança do coletivo contra o individual (...) o Supremo discutiu demoradamente o quantitativo da pena (...) o status de condenado já é suficiente, já é uma exclusão social" (p.68).

Parte do heroísmo que Veja atribui a si mesma é personificada na figura de Joaquim Barbosa e dos ministros do STF que tomam decisões mais duras em relação aos réus. Todos os ministros citados na matéria, Luís Roberto Barroso e Gilmar Mendes, se posicionaram favoráveis à execução penal.

"Os ministros (...) divergiram sobre pontos secundários mas concordaram no principal: era chegada a hora de executar as penas incontroversas e encaminhar o processo para o seu encerramento" (p.65).

O fato de Barroso ter concordado com a execução é manifestado na narrativa como um o fator positivo. O ministro foi decisivo para a concessão do direito de alguns réus, entre eles, José Dirceu, ingressar com os embargos infringentes, que poderia absolvê-lo no crime de formação de quadrilha. Veja, como narradora principal e heroína, alivia o tom das críticas a Barroso e exalta as afirmações dele sobre combate a corrupção.

"Luís Roberto Barroso (...) lembrou que, apesar das condenações anunciadas no processo do mensalão, o país continuava a ver uma sucessão de escândalos de corrupção. 'Esta ação penal pode ter, ao menos a médio prazo, um impacto salutar sobre como se faz política no Brasil'" (p.65).

Em relação à Gilmar Mendes, que votou contra os embargos infringentes, a revista dá mais espaço. O ministro é posicionado como um aliado de Joaquim Barbosa por acompanhar seus votos. O que a 
revista chama de "sintonia fina"(p.65). Para Gilmar, os embargos seriam recursos protelatórios para adiar a aplicação das penas.

Outra questão abordada pela revista que aparece nas falas de Gilmar Mendes, é como a vacância de dois ministros do STF (deixadas por César Peluzo e Aires Britto) ao longo do julgamento, pode ter influenciado no ingresso dos embargos. Veja deixa claro que esse tipo da manobra envolve o pagamento de altos valores aos advogados de defesa.

São dois motivos que embasam a Veja para discordar dos embargos infringentes: não é visto como um direito dos réus e sim um privilégio. E só quem possui poder aquisitivo tem condições de ingressar com esse tipo de recurso. Portanto, para a revista, os réus se enquadram nesse perfil de quem usa poder, influência e dinheiro para escapar das penas e manipular a mídia.

"O PT e o governo petistas jogaram pesado para que a imprensa independente, o Ministério Público, o Congresso e o Poder Judiciário compactuassem com os crimes cometidos. Os poderosos tentaram sempre reescrever a história" (p.66).

Quando se coloca no lado contrário aos dos poderosos, Veja não só quer exercer uma função heroica, como também mostra que é aliada das instituições que considera perseguidas pelo governo do PT para que o mensalão fosse esquecido e prevalecesse a impunidade.

\section{Considerações sobre a matéria em análise}

Podemos observar, nesta matéria, a confirmação do que afirmaram Traquina (1993) e Guazina (2004): a imprensa se vê como defensora do interesse público, mesmo não sendo um órgão cuja atuação contribua no combate efetivo da corrupção política. Também não é conferida à mídia o voto popular eleitoral para que tome atitudes nesse sentido.

Em box publicada na página 67, Veja dá o exemplo de Collor que, após o impeachment, foi absolvido pelo STF. Considera que, em função do que decidiu o Tribunal, na década de 90, o expresidente não poderia ser chamado de corrupto. Mas destaca que, naquele momento, Collor estava respondendo a um processo, no STF, por corrupção passiva, peculato e falsidade ideológica por receber de propina em troca de contratos com governo.

"Vinte anos depois, a impunidade pode sofrer um novo golpe - afastando a tese de a punição dos mensaleiros não foi apenas um espasmo da justiça" (p.67)

Esse argumento de que "a justiça é para todos" é usado pela revista para justificar seu posicionamento editorial. É mais um indício de que Veja quer assumir também o papel da heroína "perseguida" e "acusada" de parcialidade quando o assunto é corrupção no PT.

"O STF (...) lembrou aos poderosos que nenhum deles, por mais popular que seja, está acima das instituições e das leis que valem para todos os brasileiros" (p.68).

\section{8) Edição 2349 - 27 de novembro de 2013}

Capa: A Lei... e os fora da Lei - como a hipocrisia e a propaganda tentaram transformar culpados em vítimas e corruptos em juízes dos juízes que os condenaram

Chamada da capa: A Lei e os fora da lei - Os mensaleiros presos em Brasília reclamam de humilhações no cárcere e tentam se passar por juízes dos juízes que os mandaram para a cadeia

Resumo: já presos, os condenados pelo mensalão, entre eles, Dirceu, estariam reclamando das 
condições de suas unidades carcerárias e recebem visitas privilegiadas em relação aos outros familiares de presidiários. A revista destaca que os petistas estariam se fazendo de "vítimas" no processo por "conspiração das elites". Há uma defesa das decisões de Joaquim Barbosa, presidente do STF, a respeito das execuções penais, a partir da opinião de um advogado da PUC-SP e uma entrevista com o ex-deputado Pedro Correa um dos condenados. Nos parágrafos finais, a revista descreve em tom de satisfação o depoimento de um agente carcerário de que Dirceu, como preso, deve obediência às autoridades penitenciárias e deve responder "sim, senhor" e que a "impunidade estaria fazendo mal aos brasileiros".

Capa: De forma semelhante à capa da edição "O Poderoso Chefão", Veja utiliza elementos da cultura pop do universo da ficção, dessa vez dos quadrinhos. Joaquim Barbosa aparece de costas, com a capa preta da toga usada pelos ministros do STF. Essas características se assemelham ao figurino do super-herói Batman, criado pela DC Comics. A narrativa predominante que paira sobre Batman é de um justiceiro de Gothan City, cidade tomada pelo crime, onde nem sempre a polícia local é suficiente para combatê-lo. Barbosa não tinha poder monocrático no julgamento do mensalão, a maioria das votações foram decididas em plenário, mas mesmo assim, a revista sintetiza todo o significado do julgamento em um único personagem e o torna um herói. A imagem do então presidente do STF, que havia decidido sobre as prisões de José Dirceu, José Genoíno, Delúbio Soares, Marcos Valério e de outros condenados, está acompanhada à chamada "A Lei" que, de antemão, define a função que Joaquim Barbosa exerce na narrativa do julgamento do mensalão: ele representa bem e os "Fora da Lei", o mal.

A divisão também aparece graficamente na capa. O lado onde está a foto de Joaquim Barbosa, tem o fundo azul, que só aparece na parte de baixo, porque a perspectiva da imagem do ministro ocupa quase todo o espaço vertical da página. No lado onde estão as fotos de Dirceu, Genoíno e Marcos Valério, o fundo é preto eles estão em tamanho menor, numa montagem. Dirceu e Genoíno aparecem com o punho erguido, o gesto que fizeram antes de entrarem no prédio da Polícia Federal após se entregarem, que é um dos símbolos da esquerda.

Foto Principal: Fotos de instalações da Penitenciária da Papuda para onde José Dirceu, José Genoíno e Delúbio Soares foram encaminhados para o cumprimento das penas. Em outras imagens, Delúbio aparece com o rosto coberto e a cabeça baixa ao chegar no local. Outra foto mostra Genoíno sentado com roupas hospitalares, abaixo, José Dirceu está de punho erguido no momento em entrou na sede da Polícia Federal em São Paulo. As imagens sintetizam o tema da matéria. O foco é falar sobre possíveis privilégios que os condenados estariam tendo em relação aos outros presos na Papuda e evidenciar o merecimento pela pena. A revista também destaca que os condenados petistas não aceitariam humilhações no cárcere.

Recursos Gráficos: a revista mantém o padrão de usar fotos dos personagens citados na matéria com legendas irônicas. Há também quatro quadros (boxes) para tratar de assuntos específicos: as razões das decisões de Joaquim Barbosa, a entrevista com Pedro Correia, detalhes sobre a rotina de presos e visitantes na Papuda e uma matéria sobre Henrique Pizzolato que havia fugido após ter a prisão decretada.

Ambiente: vigilância quanto ao cumprimento da execução penal e se os condenados pelo Mensalão estão tendo privilégios na cadeia.

Espaço físico: Complexo Penitenciário da Papuda e o plenário do Supremo Tribunal Federal - STF. 
Narrador: Onisciente e intruso. A matéria foi escrita pelos repórteres Daniel Pereira, Rodrigo Rangel, Hugo Marques e Adriano Ceolim.

Narrativa: o acontecimento-intriga é o julgamento do Mensalão e o núcleo narrativo é a execução penal dos condenados. O enredo é não-linear. A narrativa começa contando um fato do passado - a resposta de Lula dada em 2005 sobre o escândalo do mensalão - para então chegar ao presente. A matéria é bastante descritiva quanto aos estabelecimentos penitenciários, às pessoas que os frequentam e como os condenados pelo Mensalão estariam se sentindo em seus primeiros dias presos e também se comportando. Há também destaque para dois destes condenados em quadros: Pedro Correia e Henrique Pizzolato.

\section{Personagens:}

Na análise desta edição, destacamos, além de José Dirceu, os personagens Lula, José Genoíno, Joaquim Barbosa e Pedro Correa. A diferença de tratamento entre eles, quanto suas caracterizações conduzem à narrativa da revista para que o leitor entenda e tenha conhecimento o que poderia estar acontecendo nos bastidores das prisões de políticos diante do que seria, na visão da revista, o costumeiro cenário brasileiro de impunidade para aqueles que possuem poder. Sentimentos e descrições físicas, psicológicas e sociais de locais, fatos e de personagens são alguns dos elementos que fazem parte da construção da história e de possíveis efeitos de sentido nos leitores.

Inicialmente, Veja caracteriza o PT como o partido dos poderosos que tenta impedir a atuação do Supremo. Na matéria, há acusações sobre isso, porém sem citar nomes ou instrumentos que poderiam concretizá-las, como podemos observar nos exemplos abaixo:

"O partido passou a gritar pega ladrão a fim de transformar em criminosos justamente aqueles que tentam enquadrá-los na lei (...) até mesmo uma tentativa frustrada de convencer senadores aliados a aprovar o impeachment do presidente do Supremo Tribunal Federal Joaquim Barbosa" (p.76).

Da mesma forma, a revista se refere ao MPF. "Tentaram cassar o mandato de Roberto Gurgel, o procurador-geral da República, que pediu a condenação dos mensaleiros” (p.80).

Segundo a revista, a relação do PT se deu porque Joaquim Barbosa não emitiu as Cartas de Sentença que deveriam preceder a prisão. "Foi com base nesses argumentos que os senadores do PT tentaram abrir um processo por crime de responsabilidade contra o presidente do STF" (p.80). Como já mencionamos acima, Veja não cita os nomes desses senadores, nem descreve como se deram essas tentativas de cassar Barbosa ou Gurgel.

Outra questão relacionada ao comportamento do partido em relação aos petistas condenados é que estaria promovendo privilégios na Papuda em relação a outros presos. A tese seria corrobada principalmente pelo fato de o governador do Distrito Federal ser |Agnelo Queiroz do PT. Conforme Veja, algumas visitas foram realizadas em dias diferentes e que o tratamento dos visitantes dos condenados pelo Mensalão seria diferente.

"Durante a revista [Antônia Leite, 57 anos, mãe de outro preso], teve que ficar completamente nua. "Eu precisei tirar a roupa toda. Já as mulheres dos politicos entraram na Papuda bonitinhas (...) a esposa de Dirceu e a de Delúbio foram liberadas dessas regras e desses obstáculos. Elas visitaram os petistas na terça-feira - e não na quarta-feira, que é o dia correto (...) humilhação e tratamento 
desrespeitoso só para os populares” (p.78).

\section{Lula}

Lula assume o papel de defensor dos companheiros de partido diante de suas prisões e Veja afirma que ele se coloca como vítima de classe. Em outras edições, a revista também reitera que o PT se diz vítima de conspiração das elites que seriam representadas pela grande mídia, onde Veja se inclui.

Nesse e em outros episódios das narrativas em que a revista critica o PT por essas argumentações, fica evidente a cobertura adversária no jornalismo político, como prevê Guazina (2011). "uma delas é assumir o papel de vítima de uma conspiração da elite inconformada com a chegada ao poder de um metalúrgico, chefe do primeiro governo popular da história e blá blá blá" (...) Lula, a eterna vítima das injustiças e do preconceito de classe" (p.76).

A revista questiona o posicionamento de 2005, quando o ex-presidente afirmou sentir vergonha do escândalo do Mensalão, e cobram coerência:

"O ex-presidente ecoava uma carta escrita dois dias antes pelos petistas presos numa cela do presídio da Papuda. No texto, o ex-ministro José Dirceu, o ex-tesoureiro Delúbio Soares e o expresidente do PT José Genoíno exigiam respeito a lei e diziam não aceitar humilhação" (p.76).

\section{Joaquim Barbosa}

Joaquim Barbosa é apresentado como o herói pois teria consertado o dano da impunidade. Além disso, é questionado e perseguido pelos vilões da narrativa: o PT e os poderosos. Para defendê-lo, Veja usa como referência quatro fontes da área do Direito. Num quadro de perguntas e respostas sobre o caso, eles tratam da Teoria do Domínio do Fato que justificou votos pela condenação de Dirceu por formação de quadrilha.

"Não, ele não errou. Nenhuma das decisões tomadas na última semana pelo ministro Joaquim Barbosa em relação aos mensaleiros desrespeitou a lei. É o que afirmam dois ministros do STF, o ex-ministro da Justiça Miguel Reale Junior, o ex-presidente do STF Carlos Velloso, o advogado Serguei Arbex, o procurador da República Antonio Cabral e o professor da PUC-SP Guilherme de Souza Nucci” (p.78).

No quadro sobre as decisões de Joaquim Barbosa, observa-se alguns desses argumentos que sustentam a função de herói do personagem.

Um dos destaques é a explicação sobre a decisão do então presidente do Supremo a respeito das Cartas. "A expedição da carta de sentença embora prevista na Lei de Execução Penal e cobrada pelo Conselho Nacional de Justiça (CNJ), é um ato meramente protocolar e administrativo" (p.78).

Outro exemplo está na página 79:

"A teoria [do Domínio do Fato] dá status de autor àquele que tem controle sobre a empreitada criminosa ainda que outras pessoas sujem as mãos em seu lugar (...). Teoria nenhuma dispensa provas. O que ampara a condenação de José Dirceu é o Código Penal, em particular, os artigos 29 e 62" (p.79). 


\section{José Genoíno}

Sobre Genoíno, Veja tenta desconstruir qualquer imaginário de inocência associada a seu problema de saúde. Há preocupação em detalhar sintomas e naturalizá-los para que isso não prejudique o objetivo de manter as mensaleiros na cadeia. A citação: "a própria tosse com sangue é comum desde que o deputado realizou a cirurgia no coração" (p.82), é um dos exemplos disso.

Há claras evidências de que a revista conduz a narrativa para que em nenhum momento o leitor se compadeça de Genoíno que, doente ou não, de acordo com a caracterização na matéria, é um petista mensaleiro e bandido. Precisa ficar atrás das grandes.

A sequências de trechos da reportagem a seguir comprova essa constatação. A defesa de Genoíno afirmou que ele passou mal na Papuda (um princípio de infarto) e estaria sem condições de ter feito a viagem de São Paulo a Brasília para ser transferido.

"Há, portanto, documentos técnicos que justificam a decisão de transferir o deputado - uma medida prudente diante de sua saúde precária, mas que dispensava a encenação de infarto" (p.82).

Na matéria, o narrador principal rebate esses argumentos, desmente o infarto, e responsabiliza o personagem pelos riscos que eventualmente poderia ter corrido.

“José Genoíno (...) ao ser detido no feriado da República, ele não quis se submeter ao exame médico (...) também não disse a Polícia Federal que não poderia fazer essa viagem. Se houve risco, não foi criado pelas autoridades" (p.80).

Ao desmentir o infarto, a revista cita que ouviu fontes, mas não as identifica. A reportagem também desaprova o atendimento dado a Genoíno após o que não acredita ter sido uma emergência.

"O que foi anunciado como uma emergência médica estava programado desde o dia anterior. Funcionários do hospital confirmaram a Veja que a ida do petista estava prevista para acontecer na véspera, mas foi adiada" (...) o deputado foi conduzido por advogados e companheiros de partido e passou a tarde na companhia da mulher e da filha, uma liberalidade que jamais seria concedida a um preso comum" (p.82).

\section{José Dirceu}

Aqui, José Dirceu é o homem de cabeça baixa, mãos para trás que diz "sim, senhor". O oposto da imagem de chefão que Veja sustentava nas edições anteriormente analisadas:

"Assim que chegaram à área onde passariam sua noite dentro da Papuda, os petistas receberam, cada um, seu kit presidiário: um lençol, um uniforme azul claro destinado aos detentos da área federal, uma caneca e uma colher de plástico, um par de sandálias de borracha e um tubo de pasta de dentes da marca sorriso - sorriso, obviamente, era tudo que não se via por ali. Dirceu torceu o nariz ao receber seu kit e disse que preferia usar os próprios pertences. $O$ outrora todo poderoso ministro de Lula foi imediatamente avisado que de que receber o kit não era uma opção. Foi o primeiro baque. Pouco depois, o ex-ministro disse que precisava falar com o seu advogado e pediu aos agentes que lhe emprestassem um celular. Dirceu foi lembrado de que não tinha esse direito. Aos poucos, ia conhecendo as agruras da prisão" (p.84).

O tom na descrição psicológica de Dirceu é de sarcasmo e comemoração por parte do narrador. O 
kit presidiário também é usado como elemento de caracterização física e social do personagem. Psicologicamente, segundo a revista, o ex-ministro estaria abatido, frustrado por não usufruir das vantagens de se estar livre, como usar o celular.

"Tão logo chegaram a Papuda, os mensaleiros foram apresentados ao código de conduta do lugar: andar de mãos para trás, cabeça baixa e sempre pedir autorização para falar, de preferência com a expressão 'por favor'. Dito e feito" (p.84).

A revista mantém a ideia de que Dirceu foi obrigado a estar em par de igualdade em relação aos outros presos quando se trata do kit e das regras de tratamento interno, porém, reitera que, ainda assim, pairam desconfianças sobre possíveis privilégios como já foi mencionado acima.

A matéria também sintetiza o sentimento de satisfação que, em sua visão, "seria dos brasileiros", a partir do relato de um agente penitenciário não identificado e provável narrador do espaço físico e do ambiente da prisão. A satisfação também é de Veja que se coloca como, por se considerar guardiã do interesse público, porta-voz desses brasileiros.

"'Nunca pensei que um dia fosse ouvir dos ilustres Genoíno, Dirceu e Delúbio um 'com licença, senhor'. E o melhor foi vê-los de mãos pra trás e de cabeça baixa. Isso não tem preço', comentou um agente penitenciário (...). Manifestações como essa - por mais controversas que sejam mostram como a impunidade dos poderosos fazia mal aos brasileiros" (p.84).

\section{Pedro Correa}

A caracterização de Pedro Correa, ex-deputado pelo PP, condenado a sete anos e dois meses de prisão por corrupção passiva e lavagem de dinheiro no julgamento do Mensalão, que também esperava receber voz de prisão é diferente em comparação as de José Genoíno e José Dirceu. Tem espaço para entrevista e não sofre escárnio. Admite o erro, se diz conformado com a prisão. Também fala que vai ajudar os outros presos por ser médico. As perguntas são respeitosas. Abaixo um dos exemplos.

"Não o constrange ser considerado um político corrupto? Evidentemente, ninguém se prepara para isso (...). Eu nunca tive um processo, nunca houve uma condenação. É o primeiro processo jurídico que enfrento na vida. Nunca tive um título protestado na vida, nunca passei um cheque sem fundos, nunca fui processado, nem por calúnia, nem por difamação. Não sou corrupto” (p.80).

\section{9) Edição 2363 - 5 de março de 2014}

Capa: Quanto riso, Oh! Quanta alegria... - O STF decidiu que eles não formaram quadrilha e estarão soltos logo. Para os brasileiros, isso é melancólico

Chamada de capa: "Quanto riso, Oh! Quanta alegria..."- O Supremo Tribunal Federal voltou atrás e decidiu que a quadrilha do mensalão não é mais quadrilha. Com isso, os chefes, que agora cumprirão pena somente por corrupção, podem deixar a cadeia a partir de agosto

Resumo: matéria ataca firmemente a decisão do STF de conceder embargos infringentes aos condenados por formação de quadrilha no julgamento do mensalão - entre eles Dirceu - e faz associação do fato com os novos ministros que tomaram posse desde 2013: Teori Zavascki e Luís Barroso que votaram pela derrubada das condenações. Também critica as doações feitas pelos 
militantes aos petistas por meio de "vaquinha". Cita também que, para o STF, Dirceu "não é mais o chefe da quadrilha" e que a Casa Civil não seria mais o bunker dos quadrilheiros.

Capa: Ao invés de fotos e montagens gráficas, a revista usa o recurso da ilustração. Como a votação dos embargos infringentes ocorreu na semana do carnaval, a edição relaciona o fato a um bloco carnavalesco composto por condenados que se beneficiaram pela decisão. Na capa, estão caricaturas de José Genoíno, José Dirceu (que está ao centro) e Delírio Soares. Há confete, serpentina e dinheiro sendo jogados para cima, enquanto os três parecem felizes. Por trás, estão várias pessoas tristes com narizes de palhaço. $\mathrm{O}$ verde, a cor do dinheiro, é a principal na ilustração. Dirceu está ao centro, com a fantasia mais luxuosa em comparação a Genoíno e Delúbio. Os dois estão com camisas listradas, como as de presidiários mostradas nos quadrinhos dos irmãos Petralhas. Porém, ao invés de pretas, as listras são vermelhas, a cor do PT. A fantasia de Dirceu e o fato de ele carregar o estandarte do "Bloco dos Mensaleiros" representa o papel de superioridade que ele tem na narrativa: o chefe da quadrilha. A chamada também possui apelo cultural. É um trecho da marcha de carnaval "Máscara Negra", que fala em "mais de 1000 palhaços no salão" e conta a história melancólica do casal Arlekim e Colombina. Apesar das referências à música não é necessário conhecê-la para entender o contexto.

Foto principal: A chamada da capa se repete e a ilustração se mantém. É acrescida uma outra página com as ilustrações de outros beneficiados Henrique Pizzolato, Kátia Rabelo, Marcos Valério e João Paulo Cunha.

Recursos Gráficos: destaque para o quadro de ministros do STF que votaram contra e a favor da extinção da pena por formação de quadrilha. A revista aponta os novos ministros Teori Zavascki, que substituiu Cezar Peluso, e Luís Barroso, que substituiu Ayres Britto, como decisivos para a mudança no quadro das condenações e as reduções de pena que levariam presos como José Dirceu a entrar no regime aberto a partir de agosto. No quadro, aqueles que votaram a favor estão do lado vermelho e os que votaram contra do lado verde. Pode-se então fazer a relação com a ilustração de capa onde os palhaços que representam os brasileiros estão pintados de verde. Há também um quadro com o detalhamento das penas revistas e em quanto tempo Dirceu, Delúbio, Genoíno e João Paulo Cunha estariam soltos e outro com uma matéria sobre uma visita que o governador do DF Agnelo Queiroz teria feito a Dirceu na Papuda.

Espaço predominante: plenário do STF, complexo penitenciário da Papuda Ambiente: decepção pela decisão do STF, vigilância em relação a possíveis privilégios dos condenados na prisão. Narrador Principal: são os repórteres Daniel Pereira e Rodrigo Rangel. Onisciente e intruso.

Narrativa: o acontecimento intriga é o julgamento do Mensalão e o núcleo narrativo é a extinção das penas de formação de quadrilha conquistada pelos réus a partir dos embargos infringentes. $\mathrm{O}$ enredo é não-linear. A matéria inicia explicando o que foi o esquema do Mensalão e o ano em que foi descoberto, 2005 e que o momento seria de decepção pela extinção da pena por formação de quadrilha. O fato noticioso só é explicado na página seguinte, quando detalha como foi a votação e as opiniões de Teori e Barroso. Dessa vez, os protagonistas da história são os ministros. José Dirceu tem mais destaque que os outros condenados citados.

A revista também comemora o que seria o "fim da impunidade". 
"Enfim, os poderosos não eram blindados com a impunidade (...). Enfim, a lei valia para todos no Brasil, de pés-rapados a excelências" (p.46).

O fim da impunidade mencionado acima se refere à matéria anterior analisada, quando trata de igualdade em relação a políticos quando o assunto é crime e prisão.

"Semana passada, no entanto, [a decisão de condenar e prender] recebeu uma emenda simbólica e prática significativa - e que beneficia a ala dos mensaleiros-chefes, às vésperas do carnaval" (p.46).

A revista também destaca as opiniões dos ministros do STF.

Teori:

"É difícil afirmar que José Dirceu ou José Genoíno tivessem se unido a outros agentes com o objetivo comum de praticar crimes" (p. 46).

Barroso:

"E considero que a causa da discrepância foi o impulso de superar a prescrição do crime de quadrilha, com consequência de elevar parte das condenações e até de modificar o regime inicial de cumprimento das penas" (p.46) "Num intervalo de apenas um ano e três meses, a condenação virou absolvição graças a duas mudanças na composição do tribunal. Os novatos Luís Roberto Barroso e Teori Zavascki, que não participaram o julgamento inicial, foram decisivos para a reviravolta" (p.47).

Para Veja, a principal característica dos ministros acima citados é a de que são novatos. A revista também afirma que o posicionamento era previsto e crítica o discurso deles por se tratar de ser totalmente o oposto á narrativa midiática contra a corrupção onde paira a desconfiança na política e nos políticos e existe pressão por julgamento e punição rápidas. A citação dita por Barroso exprime o porquê dessa discordância da revista com os ministros:

"É compreensível a indignação contra a histórica impunidade das classes dirigentes no Brasil. Mas o discurso jurídico não se confunde com o discurso político" (p.47)

Um dos argumentos usados por Veja é que os dois foram indicados pela presidente Dilma Rousseff e sabiam que poderiam mudar o resultado do julgamento com as votações referentes aos recursos.

A presidente ainda não havia sido citada nas matérias anteriormente analisadas como figura decisiva para qualquer mudança no curso do processo sobre o escândalo do Mensalão.

Mas em outras ocasiões a revista cita protestos de Lula, possíveis tentativas de deter a atuação do STF e do MPF, porém, sem nada concreto.

Os personagens detentores de poder que, até agora, movimentaram o caso de forma prática, segundo a narrativa da revista, foram Joaquim Barbosa, Agnelo Queiroz e agora a presidente Dilma.

Para fazer frente a Teori e Barroso, Veja oferece dois aliados ao ainda herói do julgamento Joaquim Barbosa: os ministros Gilmar Mendes e Luiz Fux, conforme se pode ver a seguir.

"Integrantes da corrente vitoriosa em 2012 e agora derrotada, Barbosa e o relator dos embargos Luiz Fux, alegaram que a formação de quadrilha era cristalina, uma vez que os mensaleiros executaram seus crimes durante pelo menos dois anos" (p.49).

Para Gilmar Mendes, o Mensalão era uma forma do PT se perpetuar no poder "deste tão desejado 
'bolivarianismo' à brasileira".

Para a revista, a extinção da pena por formação de quadrilha, muda inclusive a função de José Dirceu e do governo Lula em toda a narrativa do Mensalão. Até a importância do espaço físico do Palácio do Planalto onde as articulações deveriam ter sido feitas, é citada:

"Dirceu não é mais o chefe da quadrilha. Já a Casa Civil de Lula não é mais o bunker dos quadrilheiros. A partir de agora, Dirceu é apenas corrupto" (p.49).

A crítica da revista também está relacionada com o que considera ilusão de que um dia os poderosos seriam condenados e presos em par de igualdade com as pessoas comuns.

"Dirceu e Delúbio, que atentaram contra a democracia e a República com dinheiro desviado dos cofres públicos, ficarão menos de um ano na cadeia, enquanto brasileiros que nem sequer foram julgados de forma definitiva passam às vezes décadas encarcerados por crimes bem mais brandos" (p.49).

Esse "anseio" da revista é mais um elemento de que ela se considera uma guardiã do interesse público, dos mais fracos em detrimento aos poderosos. A revista se coloca novamente como heroína, defensora dos brasileiros ofendidos pela extinção da pena por formação de quadrilha.

\section{0) Edição 2365 - 19 de março de 2014}

Capa: Exclusivo - José Dirceu: a vida na cadeia

Chamada de capa: "Sou um preso exemplar" - o exemplo: leituras, visitas fora de hora, refeições diferenciadas e até podólogo à disposição. Essa é a vida dos mensaleiros na penitenciária da Papuda

Resumo: matéria começa dizendo que o ex-super poderoso do PT, José Dirceu, agora é apenas o preso 95.413 da penitenciária da Papuda, em Brasília. A capa é a primeira foto de Dirceu na cadeia divulgada pela imprensa e teria sido feita por um agente penitenciário. Veja lista os supostos privilégios que os condenados pelo mensalão teriam em relação aos outros presos a partir de depoimentos dos funcionários da Papuda. Segundo a revista, Dirceu passa o dia na biblioteca, já recebeu comida diferenciada e até uma podóloga. Também trata da situação de José Genoíno e o acusa de ter parado de tomar os remédios para forçar a prisão domiciliar.

Capa: a capa é simples, fundo preto, e foto com baixa resolução de José Dirceu no presídio.

Foto Principal: foto de José Dirceu no presídio em baixa resolução que toma as duas páginas de abertura. É explícita a importância desse momento na linha editorial da revista.

Recursos Gráficos: Simples, com fotos dos personagens citados na matéria. Um quadro sobre os crimes e penas de oito condenados no julgamento do Mensalão, entre eles, José Dirceu, Delúbio Soares e José Genoíno.

Narrativa: O acontecimento-intriga é a execução das penas dos condenados no julgamento do Mensalão. O núcleo narrativo é a rotina de José Dirceu na Complexo Penitenciário da Papuda. O enredo é não linear, a matéria começa falando de um passado recente. O texto faz um flashback de quando Dirceu era poderoso e cita que ele "um dia alimentou o sonho de substituir o chefe [Lula] no Palácio do Planalto" (p.50). 
A matéria é baseada em relatos de fontes que seriam da Papuda. A sequência de fatos relatados dá conta da rotina de Dirceu na prisão. Descrição de espaço físico, ambiente, condições físicas e psicológicas do protagonista e de outros personagens.

As características de Dirceu estão mais bem dispostas no texto, mais facilmente identificáveis, como veremos adiante. Veja conduz a narrativa para a ideia de que Dirceu está recebendo vantagens em relação aos outros presos, além disso, teriam uma "boa vida" pois passava a maior parte do tempo na biblioteca lendo livros e escrevendo redações para conseguir a regressão da pena. A revista deixa claro que a imagem de Dirceu preso é simbólica. Era o elemento que faltava até o momento para o ciclo de Dirceu desde a eclosão do escândalo do mensalão.

Espaço predominante: penitenciária da Papuda e plenário do STF.

Ambiente: desconfiança e vigilância em relação a possíveis privilégios de Dirceu e outros condenados pelo Mensalão na penitenciária da Papuda.

Narradores principais: são os repórteres Rodrigo Rangel e Hugo Marques.

\section{Personagens:}

Como se trata do protagonista da narrativa, a caracterização de José Dirceu preso é detalhada na primeira parte da matéria. Para identificá-la, ao invés de citações extraídas do texto, optamos em resumi-las no quadro abaixo. Essas descrições estão presentes nas páginas 50, 51 e 52.

\section{Quadro 5 - Caracterização de José Dirceu}

\begin{tabular}{|l|}
\hline Características Sociais \\
\hline Foi influente, agora é o preso 95413 (mais um) \\
\hline $\begin{array}{l}\text { Rotina: biblioteca e conversas - Lê em ritmo frenético - Faz refeições preparadas para ele - } \\
\text { Recebe visitas fora de hora }\end{array}$ \\
\hline $\begin{array}{l}\text { Negou privilégios durante depoimento dado aos juízes da Vara de Execução Penal do Distrito } \\
\text { Federal por meio de vídeo conferência. }\end{array}$ \\
\hline Características psicológicas \\
\hline - Sonhou em ser presidente da República \\
\hline $\begin{array}{l}\text { - Queria ser atendido por podólogo - Não abre mão de certos cuidados - Se considera um preso } \\
\text { exemplar - Corrupto resignado - Se apresentou com humildade Características físicas }\end{array}$ \\
\hline Está magro - Usa roupa branca e cabelos aparados
\end{tabular}

Fonte: original da autora.

\section{Considerações sobre a matéria em análise}

Como trata-se da última matéria a ser analisada, podemos concluir que as descrições e caracterizações de Dirceu em relação aos textos anteriores mudaram consideravelmente. Inclusive, a descrição física. Dirceu, que era visto como bonitão e conquistador em outras narrativas da revista, é aqui um homem abatido pela prisão. Isso também é observado na descrição psicológica quando se trata da resignação e da humildade. 
"Dirceu não falou em complôs da elite ou teses conspiratórias nem demonstrou disposição para continuar tentando desqualificar a Justiça, o que seus aliados insistem em fazer (...) 'só quero cumprir minha pena como foi determinado'” (p.52).

Dentro do contexto das mudanças de vida que Dirceu precisou passar na prisão, Veja cita que ele não poderia nem comemorar seu aniversário. Ao longo das análises, a revista descreve Dirceu como homem refinado, que gosta de reunir pessoas em torno dele, regados a vinhos caros e comida sofisticada. A prisão significaria solidão em um momento que seria comemorativo.

"Neste domingo, 16 de março, Dirceu completa 68 anos. O domingo não é dia de visitas e, oficialmente, ninguém está autorizado a entrar na Papuda e promover algum tipo de cerimônia lá dentro. Isso, pelo que se vê, não significa muita coisa” (p.52).

A matéria também trata do desfecho do julgamento do Mensalão. Diz que dos 38 acusados, 24 foram condenados "entre eles, banqueiros, empresários, deputados e altos dirigentes partidários" (p.52). Assim como na matéria anterior analisada, esta mantém o posicionamento de desconfiança sobre a doença cardíaca de José Genoíno.

"Exames posteriores não detectaram nada que pudesse indicar a impossibilidade de o ex-deputado cumprir a pena no presídio. Se os exames não apontarem alterações graves, Genoíno deverá se juntar novamente aos companheiros que estão na Papuda” (p.54).

O comportamento de Delúbio Soares na cadeia também faz parte do texto, apesar de Dirceu ser capa e protagonista da matéria.

"Durante a instrução do processo, em tom de deboche Delúbio previu que tudo terminaria em piada de salão. Não terminou, mas ele continua rindo, como mostra a imagem captada da Papuda" (p.53).

O incômodo pelo sorriso de Delúbio transparece a lógica da revista de que o regime semi-aberto não seria suficiente para os mensaleiros. No início da matéria, Veja revela que ninguém em sã consciência imagina que aqueles que atentaram contra o bem público poderiam levar uma boa vida na cadeia. "No máximo a vida poderia ser menos amarga" (p.50).

Podemos considerar esse momento como aquele em que o narrador relembra um fato passado e o associa ao presente para provocar a memória do destinatário. O personagem, no caso, Delúbio, era de um jeito e não mudou ou se utiliza de uma mesma frase do passado.

Outro personagem que volta à cena é Agnelo Queiroz. É o Governo do Distrito Federal que administra o complexo penitenciário da Papuda. A matéria não fala em privilégios ou sobre a rotina dos demais condenados em penitenciárias em outros estados, como Rio de Janeiro e Minas Gerais. Nem de outros presos, inclusive Roberto Jefferson, um dos protagonistas da fase escândalo que, assim como Genoíno, também enfrentava um problema de saúde.

As descrições de espaço físico da Papuda demonstram que narrador desejava uma punição mais dura aos condenados. Há críticas sobre a ala especial que teria sido construída especialmente para os presos do mensalão. Porém, os citados como privilegiados são Dirceu e Delúbio, apesar de outros condenados estarem no local. Àquela altura, Genoíno já era mantido em prisão domiciliar.

"O tratamento é totalmente diferenciado. Para os mensaleiros, foi disponibilizado um refeitório antes reservado aos agentes encarregados da vigilância. A comida é preparada por dois presostaifeiros, encarregados de elaborar o cardápio (...). No banheiro, em vez da latrina encravada no 
chão, que os detentos chamam de 'boi', há um civilizado vaso sanitário” (p.51).

A revista descreve com detalhes a rotina de presidiário e não faz a distinção entre os direitos dos presos do no regime semi-aberto, que é o caso de Dirceu e os do regime fechado. Mesmo assim, demonstra insatisfação com privilégios. Na matéria, a revista considera que o regime semi aberto é brando, mesmo sendo o que prevê a pena.

"Como o lugar fica longe dos olhos dos presos comuns, os mensaleiros podem desfrutar o tratamento especial sem que seus colegas de prisão reclamem. Dentro da cela, já foram recolhidos restos de lanche do McDonalds. Por lá também já foram vistos itens como perfumes "importados", frisa um servidor" (p.51).

A narrativa da revista não pretende dar um ponto final para a história, não propõe fins de ciclo para os personagens, como o cumprimento da pena e a reinserção a sociedade. Percebe-se a intenção do narrador em desejar que a história continue.

"Num país em que a impunidade de gente poderosa sempre foi uma tradição, a imagem [de José Dirceu preso] tem um magnífico valor simbólico. Reforça que é possível colocar e manter corruptos influentes na cadeia. Reforça que os ladrões de dinheiro público não estão acima da lei. A imagem porém também serve para advertir que, apesar de tudo isso, a vigilância tem que ser permanente" (p.50).

Veja defende os presos comuns mas não dá exemplos claros. A revista não dialoga com possibilidade de recuperação dos detentos, não entrevista ninguém sobre isso. Os "mensaleiros" não teriam remissão.

O objetivo das análises foi traçar a construção narrativa do personagem José Dirceu no período e matérias selecionadas. As características predominantes do personagem são as psicológicas: ele seria frio, calculista, pragmático, não mede esforços para alcançar o que deseja, principalmente o poder. Mesmo após o escândalo do Mensalão, ele manteve alguma influência e persuasão para ainda ter prestígio e ganhar dinheiro. Com iminência da prisão, durante o julgamento do caso, Veja mostra Dirceu temeroso e ressentido por ter sido abandonado pelos companheiros de partido, entre eles, o ex-presidente Lula. Preso, foi obrigado a seguir as regras da prisão, mas continuou sendo alvo de desconfianças por supostos privilégios que estaria tendo em relação a outros detentos.

As análises mostram também que as escolhas editoriais de Veja independem dos profissionais que lá trabalharam no período analisado, tratando-se de uma política editorial.

A seguir, passaremos às Considerações Finais, onde serão detalhadas as funções de Dirceu e dos demais personagens analisados no encadeamento das narrativas. 


\section{CONSIDERAÇÕES FINAIS}

A construção do personagem José Dirceu na revista Veja é reflexo de várias mudanças ocorridas no jornalismo nas últimas décadas, principalmente no Brasil que, após 20 anos de Ditadura Militar, conquistou o direito da liberdade de expressão e da liberdade de imprensa sobre os assuntos relacionados à política e poderes. Veja é um veículo importante para a história do jornalismo brasileiro e para a pesquisa sobre José Dirceu, pois acompanha a trajetória do personagem desde quando se tornou figura pública.

Essas mudanças aconteceram inicialmente em função da modernização dos jornais, aumento no número de leitores que se escolarizaram, a profissionalização e disciplinamento da rotina produtiva dos jornalistas. A Veja surgiu nesse contexto, em 1968. A proposta da Editora Abril era criar uma revista informativa semanal que teria matérias factuais e grandes reportagens.

A partir do AI-5, quando o regime foi endurecido pelo presidente Costa e Silva, Veja foi um dos veículos que sofreu censura entre 1969 e 1976 e teve dificuldades para publicar reportagens sobre as sessões de tortura dos presos, por exemplo. Havia também os jornais engajados e de resistência, como o Pasquim, que tiveram alguns jornalistas presos ou exilados. Iniciou-se então o caminho para um jornalismo marcado por profissionais mais individualistas e céticos em relação à política, que estavam nos cursos de comunicação das faculdades se preparando para o mercado de trabalho.

Um dos fatores que contribuiu para a profissionalização dos jornalistas foram os valores de objetividade, imparcialidade e isenção, explicados nos manuais de redação, segundo Biroli (2010). O jornal precursor nesse processo, após a ditadura militar, foi a Folha de São Paulo, o primeiro a se informatizar, um dos veículos de comunicação que se destacou nas investigações que levaram ao impeachment de Fernando Collor junto com a revista Veja conforme diz Conti (1999).

A visão sobre objetividade, considerada um valor-notícia por Traquina (1993) e ritual estratégico na rotina produtiva das redações, segundo Tuchman (1993), causa polêmica entre os estudiosos do jornalismo. No presente trabalho, fizemos a opção em 
tratá-la como imaginário da objetividade. Nele, o jornalista e as empresas justificam práticas de manipulação e se protegem de eventuais processos de difamação, como lembra Tuchman (1993). Nesse caso, o destaque da presente pesquisa é em relação aos entrevistados e personagens que, de certa forma, dão vazão à subjetividade das notícias sobre política.

Com a ajuda de órgãos fiscalizadores e de fontes do meio político, após a Constituição de 88 , os jornalistas brasileiros passaram a ter acesso às informações que antes eram sigilosas. A caça aos escândalos e a descoberta de transgressões por parte dos políticos se tornou uma das prioridades na cobertura, principalmente após o caso Collor. Isso é confirmado pelos estudos de Waisbord (2000) sobre o jornalismo watchdog (cão de guarda) na América Latina. A partir de então, se consolidou a construção de um ethos jornalístico, muito comum em democracias liberais, segundo Thompson (2002): os jornalistas se consideram fiscalizadores da política, guardiões da ética e do interesse público.

É daí que surgem os questionamentos e cobranças da imprensa pelo caráter, retidão, transparência e legalidade da classe política. Em contrapartida, nesse mesmo contexto, aumenta a dependência dos jornalistas com as fontes oficiais e do meio político por vazamentos de informações que podem constituir um escândalo midiático. Para Corrêa (2012), criou-se uma ilusão de que isso se configura como jornalismo investigativo. Tratase de jornalismo de investigação, pois apuração de evidências e provas é realizada pelos órgãos fiscalizadores.

Dentro da cobertura política, observamos os valores-notícias enumerados por Traquina (1993): conflito, inversão de valores, personalização infração e escândalo. É nesse contexto que inserimos o objeto de estudo da presente pesquisa: a construção da narrativa sobre José Dirceu na revista Veja no escândalo do Mensalão.

A partir de nossas observações, é possível afirmar que a revisa constrói um personagem na política como forma de tornar mais acessível a identificação do público com a cobertura por meio do recurso da dramatização. No contexto da disputa ideológica de Veja com o PT, José Dirceu é um alvo mais frágil de ser atingido por ter sido apontado como responsável de um ato supostamente ilícito, contra os valores morais defendidos pela 
revista, como a ética na política, que permeia o senso comum da população, mas precisamente dos eleitores.

Além disso, o sistema eleitoral brasileiro é personalista e isso fomenta cobertura jornalísticas focadas em escândalo, culpabilização de políticos mandatários e destaque a quem são os acusadores, mantendo a disputa política como termômetro para as próximas eleições ou especulando cenários incertos para o futuro.

A discussão sobre os escândalos de corrupção e o modelo de produção das notícias sobre o tema, também passa pela desconfiança na política e nos políticos tratada por Guazina (2011) e Miguel (2010). Thompson (2002) explica que esse fenômeno ocorre nas democracias liberais, como é o caso do Brasil, é uma das consequências do escândalo político-midiático, e do julgamento de caráter dos políticos e não de suas capacidades técnicas. Por isso, os políticos se preparam para serem midiáticos.

Isso ocorre também porque o modelo eleitoral concentra expectativas da população em pessoas e não em partidos ou ideologias. A política é tratada de forma hegemônica nas coberturas, com silenciamento de alguns aspectos positivos da política ou menos visibilidade aos problemas sociais mais graves do país.

O tratamento midiático para a política apenas fortalece o senso comum de que os políticos não são confiáveis, de acordo com Miguel (2010). Para ele, a mídia é responsável por difundir uma imagem negativa dos agentes da esfera pública, exige respostas rápidas e os leitores esperam essa visão.

A concorrência mercadológica, profissional e a busca pelo furo após a democratização também contribuem decisivamente para a criação dos escândalos políticos e a desconfiança na política e nos políticos pelo clima de desaprovação criado em cima dos envolvidos. Primeiro, porque as pessoas buscam os meios de comunicação para se informarem sobre política, conforme McCombs (2004). O escândalo é um processo moralizador e, ao mesmo tempo, com a espetacularizado, pode ser motivo de diversão e entretenimento.

A partir dos estudos de Thompson (2002), consideramos que o escândalo do Mensalão se enquadra nas características enumeradas pelo autor: é um escândalo político 
midiático e possui uma estrutural sequencial que é alimentada pela cobertura jornalística sobre as investigações. Também evidencia as disputas entre os campos jornalístico e político por legitimidade e credibilidade.

Após revisão bibliográfica sobre mídia e política, concluímos que Mensalão foi impactante para a opinião pública, é um escândalo político relacionado à aquisição e o exercício do poder por ter envolvido pessoas importantes e altas quantias em dinheiro. $\mathrm{O}$ escândalo também contou com os não-participantes que mostrar inquietação com o ocorrido e interesse em investigá-los. Entre eles, a Comissão Parlamentar Mista de Inquérito - CPMI dos Correios e o próprio Ministério Público Federal - MPF.

Segundo Thompson (2002), diante do escândalo, o político envolvido sofre com a perda da reputação que acumulou ao longo dos anos e os opositores podem se beneficiar disso, atraindo a eles mais credibilidade principalmente na imprensa, isso pode ser motivo de renúncia ou cassação, como foi o caso de José Dirceu, e também impede a realização de objetivos futuros. Quanto mais visibilidade o político tem, mais vulnerável fica aos escândalos por estar em constante vigilância. Constatamos isso em relação à cobertura de Veja sobre o ex-ministro.

No presente trabalho, as matérias publicadas por Veja sobre o envolvimento de José Dirceu no Mensalão, foram analisadas sob a ótica dos estudos narrativos, pressupondo que são componentes de um enredo e constroem um personagem que é central na narrativa da revista em vários episódios sobre o caso. Por isso, foram analisadas 12 matérias, publicadas em dez edições de capa sobre o ex-ministro entre 2005 e 2014.

Entre os resultados da pesquisa estão a função predominante de José Dirceu, a de anti-herói trágico, o personagem que não evolui na história, não se recupera dos danos que causa e que a revista se utiliza de elementos da narrativa seriada para (presente na TV e no cinema) para caracterizá-lo por meio de cenas dramáticas, descrições físicas, psicológicas e de ambiente.

Com base nos estudos narrativos levantados para o estudo, as notícias podem ser analisadas sob a ótica da narrativa também por possuírem elementos como: tempo, espaço, ambiente e narrador. Segundo Motta (2013) a narrativa jornalística conta a história do presente e evidenciam conflitos presentes no jornalismo político. 
Para Motta (2013) o analista de narrativas jornalísticas precisa reunir todos os episódios da história em função da narrativa jornalística não tem começo, meio e fim. A partir disso, conclui-se que as dez capas de Veja sobre José Dirceu podem ser divididas em episódios, semelhantes aos das séries de TV, que se interligam e compõe uma intriga que vai desde o início do escândalo, julgamento do caso no STF e a prisão do ex-ministro. A narrativa da revista também é influenciada pela diferença ideológica com o governo Lula que, na visão de Araújo (2013), constrói discursivamente os atores sociais envolvidos na história.

Constatamos que a revista Veja recobre de desconfiança a atuação política de José Dirceu desde o movimento estudantil de 68 quando duvidou de sua capacidade como líder e o colocou como um dos responsáveis pela violência ocorrida no episódio conhecido como Batalha da Rua Maria Antônia segundo Coelho e Souza (2008). As características de Dirceu destacadas pela revista durante a ditadura voltam a ganhar evidência em outras ocasiões, entre elas, em 2002, quando da possibilidade de Lula chegar à presidência da República e também no escândalo do Mensalão. A desconfiança se mantém no período pós-escândalo, quando a revista investiga as visitas que Dirceu recebe em seu quarto de hotel em Brasília em 2011, quando o define como "O Poderoso Chefão", e considera que ele ainda tinha poder e influência sobre o PT e o governo naquele período e, durante a prisão, quanto a possibilidade do ex-ministro receber privilégios na Penitenciária da Papuda em relação a outros presos.

Entendemos que, quando a revista Veja se assume como personagem que tem a função de ser antagonista de personagens políticos em suas narrativas, isso pode afetar a legitimidade e credibilidade do veículo que, mesmo sob críticas em relação a parcialidade ideológica com o governo do PT e com os movimentos sociais de esquerda, apresenta-se e vende como produto jornalístico confiável. Observou-se, por exemplo, na amostra pesquisada uma minuciosa descrição psicológica de José Dirceu; realizada, porém, sem entrevistá-lo para ouvir o outro lado, como sugerem as boas práticas jornalísticas.

Foi possível constatar que existe um ciclo midiático do personagem José Dirceu traçado pela revista. A conclusão sobre a existência deste ciclo foi possível após cruzamento do ciclo do herói proposto por Campbell (1997) - nascimento, chamado, luta, derrota, retorno e vitória-, à estrutura sequencial dos escândalos midiáticos de Thompson 
(2002) pré-escândalo, escândalo, clímax e as consequências - e os relatos sobre a vida de José Dirceu, marcada por reviravoltas e pontos de virada, segundo explicamos no capítulo 3.

Concluímos que a revista contempla vários momentos da biografia do ex-ministro, relatando histórias do presente de acordo com o período. O ciclo seria o início da carreira política, acúmulo de reputação, ascensão e queda.

A partir do que Todorov (1971) chama de encadeamento, alternância e encaixamento, podemos considerar que elementos compõem a narrativa sobre os escândalos políticos, pois várias outras histórias surgem ao longo das investigações e da visibilidade do caso na mídia dentro de uma narrativa maior. Durante auge do Mensalão, em 2005, por exemplo, a revista buscou evidências que comprovassem a participação do ex-ministro no esquema e relatou o que ele estaria fazendo nos bastidores.

José Dirceu é anti-herói trágico da revista não só durante o escândalo do Mensalão, mas durante toda a sua história. Veja faz associações de ações atribuídas a ele no passado com o presente e nas projeções futuras gerando a desconfiança sobre ele em todos os momentos. Conforme Bird e Darnenne (1993), notícias trazem valores pré-estabelecidos como o bem o mal, além de características próprias relacionadas à cultura. Para Tuchman (1993), os relatos noticiosos são uma realidade seletiva e a partir deles os jornalistas constroem "estórias".

Propp (2001) propõe que o personagem que assume a função de inimigo se apodera de bens, foge, sequestra e engana. Constatamos que essas são algumas das definições compõe o imaginário de Veja sobre o José Dirceu.

Constatamos que os jornalistas que escrevem as matérias da Veja no período que foi estudado são narradores oniscientes (sabem o que se passa ao redor) e intrusos (dão opiniões sobre o que é narrado). As fontes são narradoras também e contribuem para a organização dos relatos de bastidores, onde o jornalista não pode estar. A negociação entre fontes e jornalistas durante a apuração fazem parte da construção dos personagens, segundo Mesquita (2003). Isso justifica o que acontece com José Dirceu em Veja. A revista relata fragmentos da biografia do ex-ministro de acordo com suas necessidades editoriais. 
Portanto, o personagem não é real, é construído, é uma figura do discurso como também afirma Motta (2013).

Mesquita (2003) também aponta que o personagem é parte essencial do jornalismo e o modelo produtivo das notícias preza por imagens simplificadoras que evidenciam valores e visões de mundo, principalmente se o personagem é uma liderança. Na narrativa política, por exemplo, há protagonistas e antagonistas e o que caracteriza o conflito. Nesse espaço midiático e em outros as figuras anti-heroicas compõem modelos de identificação das personagens, como aponta Mesquita (2003).

Motta (2013) afirma que a partir dos personagens o narrador pode traçar estratégias argumentativas que geram efeito de sentido, no caso da narrativa jornalística, para causar efeito de real e, dessa forma, fazer com o que os destinatários acreditem que os jornalistas estão relatando fatos reais. Entre elas, estão as aspas com afirmações dos entrevistados, os números e as datas. Mas Motta (2013) completa que essas estratégias criam efeitos catárticos nos destinatários. McCombs (2004) considera que a mídia pode influenciar no comportamento das pessoas após ampla exposição das matérias e isso faz parte do processo de compreensão das mensagens.

Nas matérias analisadas, constatamos a presença de elementos narrativos, descrição de episódios, das falas dos personagens e a caracterização psicológica de José Dirceu sobressaindo sobre sua atuação política. Nos concentraremos na conclusão para as semelhanças da trajetória de Dirceu na Veja com as narrativas seriadas e de TV onde consideramos haver predominância dessas características que levantamos a partir dos estudos de Rodrigues (2014) e Vogler (2006):

Cria-se atmosferas, metáforas e imagens como referências para o início da narrativa com o objetivo de transmitir sentimentos ao público.

- Os textos da revista alertam os destinatários para as questões que serão enfrentadas pelos personagens.

- São elaborados títulos metafóricos com a intenção de deixar a plateia curiosa. "Ele assusta o governo"; "Destemido e Temido, agora no banco dos réus"; "A vida na cadeia". 
- Gestos personalizados do narrador indicam o clima da narrativa: triste, irônico, dramático, etc.

- Acontecimentos que precedem a entrada do protagonista são elencados antes do desenvolvimento da narrativa o que, para um texto jornalístico, torna o enredo nãolinear.

- Na primeira fase, o Mundo Especial do governo Lula é a eclosão do escândalo do Mensalão. Na segunda, é o julgamento. Na terceira, a prisão dos condenados.

- São expostos dilemas íntimos e morais dos personagens. São informadas suas atitudes, estados emocionais, problemas e futuras soluções. Sempre há comportamentos descritos que definem e revelam os personagens. Dirceu é marcado como frio, pragmático e sem limites pelo poder, por exemplo. Quais seriam os objetivos de Dirceu com o Mensalão, segundo a narrativa de Veja? Se manter no poder. Seus impulsos? Fazer tudo o que for necessário para isso. Seus desejos? Ser rico, poderoso, ter sido presidente da República. Sua necessidade? Se salvar em meio ao escândalo.

- Na posição de narradora, Veja propõe como necessidade universal a punição dos poderosos - o alvo principal são os acusados de participar do Mensalão que integram a cúpula do PT. Se baseia na ideia de que o Brasil precisa deixar de ser o país das "maracutaias", vantagens e de impunidade para políticos. Esse é o problema da narrativa que precisa ser resolvido desde a primeira fase da trama.

- Um dos poucos personagens que crescem e enfrentam desafios na narrativa de Veja sobre o Mensalão é Joaquim Barbosa. O fato é que, durante a eclosão do escândalo, o Roberto Jefferson não é suficiente para reparar o dano. Veja elege o herói no âmbito da justiça, no caso, um ministro do STF decisivo para o julgamento.

- Dirceu é marcado por ter cometido uma falha e não pode ser perdoado por isso. Há uma semelhança segundo Vogler (2006), com as histórias dos heróis trágicos nas tragédias gregas, com a daqueles personagens que são levados a destruição mesmo possuindo qualidades. 
- “Os heróis trágicos, frequentemente, são pessoas superiores, com poderes extraordinários, que tendem a se considerar iguais aos deuses ou até melhores que eles. Ignoram advertências sensatas ou desafiam os códigos morais, achando que estão acima das leis divinas" (Vogler, 2006, p.101).

- Não faltam nos textos as histórias pregressas e exposição daquilo que deixou o personagem na situação de risco exposta no começo da história. Também são destacados a classe social do personagem José Dirceu, sua formação, seus hábitos, experiências, condições sociais dominantes e forças adversárias que possam afetálo. Para Vogler (2006), isso é tudo que a plateia precisa saber para compreender o personagem. "Muita coisa se descobre pelo o que as pessoas não fazem ou não dizem (...) as sucessivas camadas de defesas que protegem um segredo difícil vão sendo rasgadas" (p.104).

- É possível isolar características de Dirceu em todas as matérias, ou seja, a revista estabeleceu um mundo inconfundível para o personagem. Ele mescla características de herói, mentor, anti-herói trágico e vilão psicopata. Mas a narrativa predominante de Veja sobre ele é a de anti-herói trágico.

- Nos roteiros de TV e cinema, sempre acontece uma situação desconfortável que vai crescendo. Isso caracteriza também a narrativa dos escândalos político-midiáticos. No caso do Mensalão, o gatilho é a matéria da Veja sobre a propina dos Correios, que geram as entrevistas de Roberto Jefferson à Folha de São Paulo com as revelações sobre o esquema.

- "Como uma bruxa que pronunciasse uma maldição" (Vogler, 2006, p.119), Roberto Jefferson, anuncia a demissão de Dirceu e se torna seu antagonista. Porém, para a Veja, ele é uma espécie de anti-herói que participa do erro, mas tentar consertar o dano. Após as matérias sobre os escândalos, Roberto Jefferson perde destaque, mas sua importância para eclosão do escândalo é lembrada de forma recorrente nas edições analisadas.

- "Histórias são símbolos da curiosidade humana, do impulso poderoso de conhecer todos os segredos, tudo o que está escondido" (Vogler, 2006, p.120). Aqui entra a 
função da Veja de elucidar os crimes. Os narradores são intrusos, participam da história, inclusive com exemplos moralizantes.

- Não há encontros com mentores. Até porque até o julgamento, não há um herói identificado que precise de proteção e orientação. O próprio Joaquim Barbosa não parece precisar disso conforme a narrativa da revista.

- No entanto, "a máscara do mentor pode ser usada para enganar um herói e aliciá-lo para uma vida de crimes" (Vogler, 2006, p.127). É o que aparece na relação de Dirceu e Lula na narrativa de Veja na fase escândalo. Lula, aqui no que seria a posição de herói, seria vítima de Dirceu, seu mentor. Segundo a Veja, Dirceu também se sentiu traído por Lula por sua demissão da Casa Civil. Ou seja, fica evidente o conflito os dois.

- Lula vive seu ciclo do herói desde as greves do ABC Paulista. Não recusa seus chamados, porém é derrotado em eleições presidenciais. Dirceu surge como mentor de Lula. O ex-ministro teve auxílio técnico para isso e realizou articulações políticas de bastidores. O herói (Lula) confia a Dirceu (Mentor) algumas atribuições para ficar livre e ter contato direto com o povo. Lula finalmente vence a jornada em 2002. No poder, Dirceu continua exercendo a função de mentor, começa o escândalo do Mensalão e, desde então, ele vai sendo liquidado. É dentro desse imaginário que Veja constrói o papel de anti-herói trágico de Dirceu.

- “A morte deve ser real e não uma conveniência do enredo" (Vogler, 2006, p.166). Veja desenvolve a ideia de que o mensalão destruiu Dirceu, que o imaginário heroico sobre ele acabou.

- Os dilemas de alguns personagens criam expectativas, principalmente, durante o escândalo do Mensalão. Uma parte deles é de Lula e de Delcídio Amaral que precisam "cortar na carne" e estão sob pressão.

- Alguns personagens são transitórios (camaleões) e mudam de lado como ocorreu com Roberto Jefferson. É assim na política, principalmente no Brasil, marcada pelas alianças partidárias em nome da governabilidade. 
- As etapas de evolução do herói na história não acontecem com Dirceu na Veja. Na fase ressureição, por exemplo, a narrativa evidencia mudanças na personalidade do personagem, já amadurecido pela jornada tanto no comportamento, quanto na aparência. Dirceu já não se enquadra nesse ponto. Desde o mensalão, ele tentou ressurgir, mas não conseguiu e, ao fim, está preso e fragilizado.

- Podemos concluir que no período em que as matérias foram analisadas, José Dirceu já vai superado o seu ciclo do herói, iniciado na Ditadura Militar: Mundo comum (vivia na cidade natal): Passa Quatro; Chamado à Aventura (resolveu ir embora pra estudar): ida a SP/entrada no movimento estudantil; Travessia do Primeiro Limiar (primeiras dificuldades): Conflitos entre estudantes na Rua Maria Antônia; Testes, aliados e inimigos (novos desafios): Congresso da Une/prisão/exílio em Cuba; Aproximação da caverna oculta (local onde se prepara para enganar o vilão): volta ao Brasil como clandestino; Recompensa: anistia/desfaz a plástica; Retorno com o elixir: retoma a carreira política

- O ciclo que José Dirceu estava vivendo até a eclosão do escândalo do Mensalão foi o que começou após a anistia. Na Política, funda o PT, se aproxima de Lula, vira deputado, se torna presidente do PT e reorganiza o partido que era muito dividido em tendências. Daí vem a fama de passar o rolo compressor; Eleições 2002: articula alianças políticas e empresariais para eleger Lula, assume o poder; Mensalão: tudo se descontrói em sua volta e ele é derrotado.

Veja utiliza adjetivos, figuras de linguagem e termos precisos como horários, locais e detalhes de ambientes físicos como estratégias argumentativas em relação a José Dirceu. É importante lembrar que adjetivação não é recomendada pelos manuais de redação, segundo Biroli (2010), pois prejudicaria a objetividade jornalística e o afastamento do jornalista narrador em relação aos fatos. A percepção de Veja sobre Dirceu ser uma pessoa impiedosa e temida demonstra a importância do personagem para a revista demarcar o seu juízo de valor sobre a corrupção baseada na diferença ideológica do veículo em relação ao PT.

Segundo Motta (2013) os personagens são recobertos de significações para enquadrá-los nos desejos e intenções do narrador. "Em todas as narrativas, mesmo nas 
narrativas fáticas, não estamos nos referindo a pessoas reais, mas personagens, figuras criadas pelo discurso" (Motta 2013, p.208). Essa linha de raciocínio é semelhante a de Mesquita (2003), como observado no item 4.1.

A matérias analisadas evidenciam o que vem a ser ciclo político-midiático vivido por José Dirceu desde o início de sua trajetória política: início da carreira política (movimento estudantil), acúmulo de reputação (quando líder da oposição ao governo FHC no Congresso), ascensão (quando chegou ao poder) e queda (depois do escândalo do Mensalão). A última etapa seria o ostracismo, ou seja, o sumiço da pessoa envolvida no escândalo. O diferencial em relação a José Dirceu o ciclo ainda está aberto porque ele ainda é destaque nos veículos de comunicação, mesmo estando preso.

Ruiz (1980) lembra que no decorrer da história, o narrador pode possuir espírito crítico e espírito de crítica. Ruiz (1980) afirma que o espírito crítico busca a seriedade e a verdade, além de ponderar razões e confrontar motivos. Já o espírito de crítica é manifestado por inquietação pessoal, julgamento e definição de juízo de valor que pode levar ao ceticismo. Portanto, observamos, na matéria analisada, tendência da revista pelo espírito de crítica em relação ao personagem.

Obviamente, nossa pesquisa não se esgota aqui porque o personagem José Dirceu continua na mídia e, consequentemente nas páginas da revista Veja. Provavelmente, o ciclo midiático do ex-ministro não se fechou, apesar de outros condenados pelo escândalo do Mensalão ainda estarem presos, porém sem a mesma visibilidade.

Em agosto de 2015, José Dirceu foi preso novamente, alvo das investigações da Operação Lava-Jato, acusado de fazer parte de um esquema de recebimento de propina de empresas que prestavam serviço para a Petrobras. Até o momento, ele está em uma Penitenciária Federal de Curitiba, onde cumpre prisão preventiva em regime fechado.

Novos problemas de pesquisa podem ser suscitados tais como identificar as funções de outros personagens que giram em torno de Dirceu após o Mensalão, entre eles, Joaquim Barbosa e o juiz federal Sérgio Moro, que decretou a prisão de Dirceu na Lava-Jato. Isso pode ser feito por meio da relação heroica que a mídia faz da imprensa nos casos de corrupção, como aponta Araújo (2013). 
Outros dois personagens que também podem ser melhor investigados: se houve evolução do papel do personagem Roberto Jefferson após o escândalo do Mensalão, cuja a prisão não teve a mesma divulgação que a de Dirceu, e de José Genoíno no mesmo período analisado pela presente pesquisa. Observou-se que a função do ex-deputado e presidente do PT não ficou bem definida na narrativa do escândalo em função da visibilidade de José Dirceu. Mas estes são aspectos a serem desenvolvidos em outras oportunidades de pesquisa 


\section{REFERÊNCIAS}

ABDALA JUNIOR, Benjamin. Introdução à Analise de Narrativa. São Paulo, Scipione, 1995.

ADGHIRNI, Zélia Leal; MOURA, Dione Oliveira; PEREIRA, Fábio Henrique (orgs.). Jornalismo e Sociedade - Teorias e Metodologias. Florianópolis.Insular, 2012.

ALDÉ, Alessandra. Vasconcelos. Ao Vivo de Brasília: Escândalo Político, oportunismo e circulação de notícias. Revista de Ciências Sociais, v.39, n.2, 2008. Os 61-69.

Alessandra. A construção da política: democracia, cidadania e meios de comunicação de massa. Editora FGV, Rio de Janeiro, 2004.

ALMEIDA, Maria Fernanda Lopes. 1968-1976: Veja Sob Censura. Jabuticaba. 2008, São Paulo.

ALSINA, Miguel Rodrigo. A construção da notícia. Editora Vozes, Rio de Janeiro, 2009.

ARAÚJO, B. B. Justiça, Media e Espaço Público: A cobertura jornalística do

Julgamento do Mensalão em Veja e Época. Dissertação de Mestrado em Comunicação e Jornalismo. Faculdade de Letras da Universidade de Coimbra, 2013.

AZEVEDO, Fernando Antônio. O declínio da grande imprensa. Revista USP, São Paulo, n.9, p.84-101, junho/agosto, 2011.

BENJAMIN, Walter. Obras Escolhidas - Magia, Técnica, Arte e Política. Editora Brasiliense. São Paulo, 1980.

BOURDIEU, Pierre. The Political Field, the social Field and the jornalistic Field. In benson, Rodney e Neveu, Erick. Bourdieu and the journalistic field. Malden, Polity press, 2005.

, Pierre. O Poder Simbólico. Rio de Janeiro: Bertrand Brasil, 1998.

BIRD, S. Elizabeth. DARDENE, Robert W. Mito, Registo e 'Estórias': explorando as qualidades narrativas das notícias. P. 263-277 
BIROLI, Flávia. Miguel, Luis Felipe (org). Mídia: representação e democracia. Editora Hucitec. São Paulo, 2010.

Flávia. Técnicas de poder, disciplinas no olhar: aspectos da Construção do "Jornalismo Moderno" no Brasil. 195-222 In Mídia: representação e democracia. Editora Hucitec. São Paulo, 2010.

BUCCI, Eugênio. Sobre Ética e Imprensa. Companhia das Letras, São Paulo, 2008.

CABRAL, Otávio. Dirceu - A Biografia. São Paulo: Record, 2013.

CAMPBELL, J.O Herói de Mil Faces. São Paulo: Cultrix, 1997.

CHANDHOKE, Neera. Revisiting the crisis of representantion thesis: the indian context. Democratization. v.12, n.3, p. 308-330

COELHO, Cláudio Novaes Pinto. Valle, Maria Ribeiro. A Revista Veja e o Movimento de 68: entre o engajamento e o entretenimento. Revista Clio - Série Revista de Pesquisa Histórica, No 26-1, 2008. Pgs de 139 - 154.

CONTI, Mario Sergio. Notícias do Planalto - a imprensa e Fernando Collor. Companhia das Letras, São Paulo, 1999.

CORRÊA, Thomaz Souto. A Era das Revistas de Consumo. In Martins, Ana Luiza e Luca, Tania Regina de. História da Imprensa no Brasil. ps. 208-232. Editora Contexto, São Paulo, 2008

CORREIA, Eduardo Luiz. História e Ficção na Narrativa de Escândalo Midiático. Tese de doutorado. Universidade de Brasília, 2011.

CUNHA, Maria Jandira; MOTA, Célia Ladeira; MOTTA, Luiz Gonzaga (orgs.).Narrativas Midiáticas. Florianópolis. Insular, 2012.

DIRCEU, José. PALMEIRA, Vladimir. Abaixo a Ditadura: o movimento de 68 contado por seus líderes, Garamond, 1998.

DOBBECK, Vera Lúcia Aparecida de Castro. "A Imprensa - o dito e o não dito: uma análise da revista Veja, 14o Congresso de Leitura do Brasil. Associação de Leitura do Brasil, 2003, Campinas (SP). 
DUARTE, Jorge. Barros, Antonio (orgs.). Métodos e Técnicas de Pesquisa em Comunicação. São Paulo: Atlas, 2012.

GANCHO, Cândida Vilares. Como analisar narrativas, editora ática, São Paulo, 2002.

GUAZINA, Liziane. Jornalismo em busca de credibilidade: a cobertura adversária do Jornal Nacional no escândalo do Mensalão. Tese de Doutorado em Comunicação Social. Universidade de Brasília, 2011.

Liziane. Campos em Disputa: jornalismo versus política na cobertura do Jornal Nacional sobre o escândalo do Mensalão. Trabalho apresentado no $11^{\circ}$ Encontro Nacional de Pesquisadores em Jornalismo, 2013.

, Liziane; MOTTA, Luiz Gonzaga. O Conflito como categoria Estruturante da Narrativa Política: o caso do Jornal Nacional. BrazilianJournalismResearch, v.6, p.132-149, 2010.

, Liziane. Quando cultura política e subcultura jornalística andam de mãos dadas: a desconfiança na política em tempos de escândalos. Trabalho apresentado no $23^{\circ}$ Encontro Anual da Associação Nacional dos Programas de Pós-Graduação em Comunicação - Compós, 2014.

GOMES, Wilson. Transformações da política na era da comunicação de massa. Paulus, São Paulo, 2007.

GONÇALVES, Souza e Renó. A mídia constrói imagens: José Dirceu e o Mensalão. Trabalho apresentado no Congresso Multidisciplinar de Comunicação para o Desenvolvimento Regional. São Bernardo do Campo, São Paulo, 2006.

GUIMARÃES at al. A Mídia e o Poder: Análise da cobertura do Caso Waldomiro Diniz. Trabalho apresentado no $27^{\circ}$ Congresso Brasileiro de Ciências da Comunicação (Intercom), 2004.

ISER, Wolfgang. Teoria da Ficção, UERJ, Rio de Janeiro, 1999.

KRIEGER, Gustavo. Novaes, Luiz Antonio. Faria, Tales. Todos os sócios do presidente. Scritta Editorial. 1992, São Paulo. 
LAURENZA, Ana Maria de Abreu. Batalhas em letra de forma: Chatô, Wainer e Lacerda. In Martins, Ana Luiza e Luca, Tania Regina de. História da Imprensa no Brasil. ps. 179205. Editora Contexto, São Paulo, 2008.

LEITE, Paulo Moreira. A outra história do Mensalão: as contradições de um julgamento político. Geração, São Paulo, 2013.

LIMA, Venício Artur de. Mídia: crise política e poder no Brasil. São Paulo. Perseu Abramo, 2006.

Cenários de Representação da Política, CR-P. In Comunicação e Política - Conceitos e Abordagens. Antonio Albino Canelas Rubim (Org.).Unesp, 2004.

MARKUN, Paulo. O Sapo e o Príncipe: personagens, fatos e fábulas do Brasil contemporâneo. Objetiva, Rio de Janeiro, 2004.

MARTINS, Ana Luiza e Luca, Tania Regina de. História da Imprensa no Brasil. Editora Contexto, São Paulo, 2008.

MARTINS, Franklin. Jornalismo Político. São Paulo: Contexto, 2005.

MATOS, Carolina. Jornalismo e Política Democrática no Brasil. Publifolha, São Paulo, 2008 .

MCCOMBS, Maxwell. A Teoria da Agenda: a mídia e a opinião pública. Editora Vozes, Rio de Janeiro, 2009.

MENEGATTI, Luiz Gustavo Cella; TEIXEIRA, Níncia Cecília Ribas Borges . A Semiótica no Cartaz de Godfather I. Artigo apresentado no XIII Congresso de Ciências da Comunicação da Região Sul - Intercom Sul. Chapecó, Santa Catarina, 2012.

MENDEZ, Rosemary Bars. Pompeu de Sousa: jornalista que mudou o jornalismo brasileiro. Tese de Doutorado em Comunicação Social. Universidade Metodista de São Paulo, 2006.

MESQUITA, Mário. O quarto Equívoco - o poder dos media na sociedade contemporânea. Minerva, Coimbra, 2003. 
MIGUEL, Luis Felipe. A mídia e o declínio da confiança na política. In . In Mídia: representação e democracia. ps 223-240. Editora Hucitec. São Paulo, 2010.

MOTTA, Luiz Gonzaga. Análise Crítica da Narrativa. Brasília. Editora Universidade de Brasília, 2013.

A narrativa mediada e a permanência da tradição: percurso de um anti-herói brasileiro. Estudos de Literatura Contemporânea, n.38. Julho/Dezembro. 2011. P. 185-2012.

NASCIMENTO, Solano. Jornalismo sobre investigações: relações entre o Ministério Público e a Imprensa. Tese de Doutorado. Universidade de Brasília - UnB, 2007.

O'DONNEL, Guillermo Democracia Delegativa? Novos Estudos v. 31. ps. 25-40.

ORTEGA, F e HUMANES, M.L. Algo más que periodistas - sociologia de uma profissión. Barcelona, Arial, 2000.

PEREIRA, Merval. Mensalão: O dia a dia do mais importante julgamento da história política do Brasil, Record, Rio de Janeiro, 2012.

PROPP, Vladimir I. Morfologia do Conto Maravilhoso. São Paulo. CopyMarket.com, 2001.REIS, Carlos. Narratologia e teoria da Personagem. Revista do Programa de PósGraduação em Letras da Universidade de Passo Fundo, v.2,p.26-36, jan./jun. 2006

RODRIGUES, Malena Rehbein. Imprensa e Congresso ou Como a mídia pauta a política. Brasília:Câmara dos Deputados, Coordenação de publicações, 2002.

RODRIGUES, Sonia. Como escrever séries: roteiro a partir dos maiores sucessos da TV. São Paulo:Aleph,2014.

ROSAVALLON, Pierre. Counter-democracy: policy in a age of distrust. New York: Cambrigde University, 2008.

RUIZ, João A. Metodologia Científica. São Paulo. Atlas, 1980.

SANTOS, Maíra Blanchini de. De Love Lucy a Lost: Aspectos históricos, estruturais e de conteúdo das narrativas seriais televisivas norte-americanas. ps 473-506. In Amaral at al. Perspectivas da Pesquisa em Comunicação Digital, São Paulo, Intercom, 2010. 
SCHMITT, Carl. O Conceito do Político. Rio de Janeiro. Vozes, 1992.

TAVARES, Daniel Nardin. Nos Esconderijos da Virtualidade O "homem cordial" nas vinculações via redes sociais online entre senadores e cidadãos. Dissertação de Mestrado, 2014.

THOMPSON, John. O Escândalo Político: poder e visibilidade na era da mídia. Rio de Janeiro. Vozes, 2002.

TODOROV, Tzvetan. As categorias da narrativa literária. In Análise Estrutural da Narrativa, os 211-256. trad. Milton José Pinto. Editora Vozes, 1971.

TUCHMAN, Gaye. A Objetividade como Ritual Estratégico: uma análise das noções de objetividade dos jornalistas. In .) Jornalismo: questões, Teorias e Histórias. Lisboa, Vega, 1993.ps. $74-90$

Contando estórias. In. Jornalismo: questões, Teorias e Histórias. Lisboa, Vega, 1993. ps. 258-262

Making News. A Study in the Construction of Reality. New York: Free Press, 1978.

TRAQUINA, Nelson (org.) Jornalismo: questões, Teorias e Histórias. Lisboa, Vega, 1993. , Nelson. Teorias do Jornalismo. Florianópolis: Insular, 2005.

VAN DJIK, Teun a. Cognição, Discurso e Interação. Contexto. São Paulo, 1996. . Discurso e Poder. Contexto. São Paulo, 2012.

VILLA, Marco Antonio. Mensalão: o julgamento do maior caso de corrupção da história política brasileira. Leya, São Paulo, 2012.

VILLAMÉA, Luiza. Revolução Tecnológica e reviravolta política. In Martins, Ana Luiza e Luca, Tania Regina de. História da Imprensa no Brasil. ps. 249-267. Editora Contexto, São Paulo, 2008.

VOGLER, Christopher. A Jornada do Escritor. Nova Fronteira, Rio de Janeiro, 2006. 
WAISBORD, Silvio. Watchdog Journalism in South America: news, accountability and democracy. Columbia University Press, New York, 2000.

WARREN, M. Democracy and Trust. Cambridge: Cambridge Univ. Press, 1999

Reportagens de Veja

Veja. “Tem Conserto?”. São Paulo. Edição 1910, 22 de junho, ps. 46 a 53, São Paulo, Abril, 2005.

Veja. “O Grande Erro”. Edição 1911, 29 de junho, ps. 59 a 69, Abril, São Paulo, 2005.

Veja. “O Risco Dirceu”. Edição 1916, 3 de agosto, ps. 56 a 66, Abril, São Paulo, 2005.

Veja. "O Poderoso Chefão". Edição 2232, 31 de agosto, ps. 72 a 78, Abril, São Paulo, 2011.

Veja. "Réu”. Edição 2280, $1^{\text { }}$ de agosto, p.66 a 70, Abril, São Paulo, 2012.

Veja. “A Verdade sobre José Dirceu”. Edição 2325, 12 de junho, ps. 62 a 69 , Abril, São

Paulo. 2013

Veja. "Uma lição aos Corruptos". Edição 2348, 20 de novembro, ps. 60 a 68, Abril, São Paulo, 2013.

Veja. "A Lei e os Fora da Lei”. Edição 2349, 27 de novembro, ps. 76 a 84, Abril, São Paulo, 2013.

Veja. "Quanto Riso! Oh! Quanta Alegria”, Edição 2363, 5 de março, ps. 44 a 51, Abril, São Paulo, 2014.

Veja. "José Dirceu: a vida na cadeia”, Edição 2365, 19 de março, ps. 48 a 55, Abril, São Paulo, 2014. 


\section{ANEXOS}

Figura 3: Edição 1910, de 22 de junho de 2005

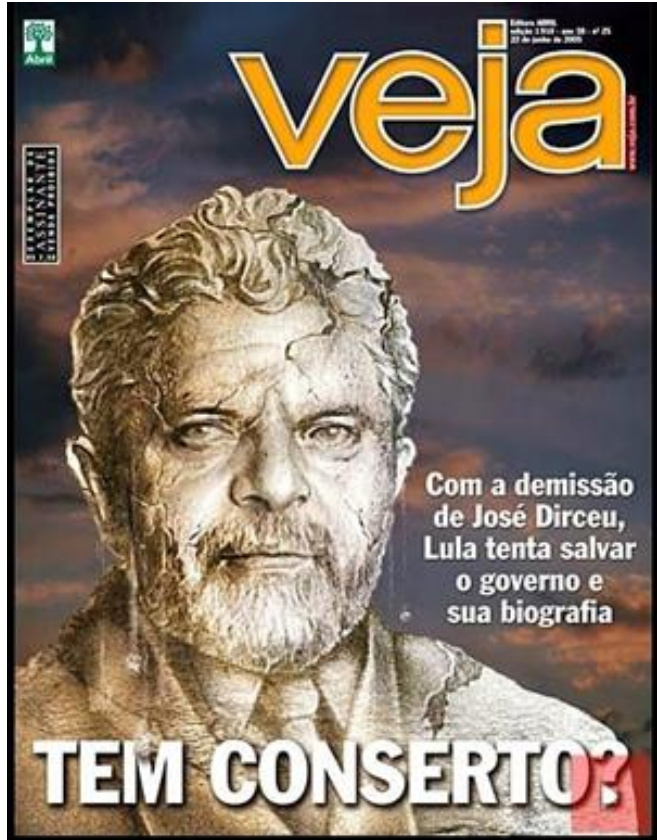

Fonte: Reprodução Acervo Revista Veja

Figura 4: Edição 1911, de 29 de junho de 2005

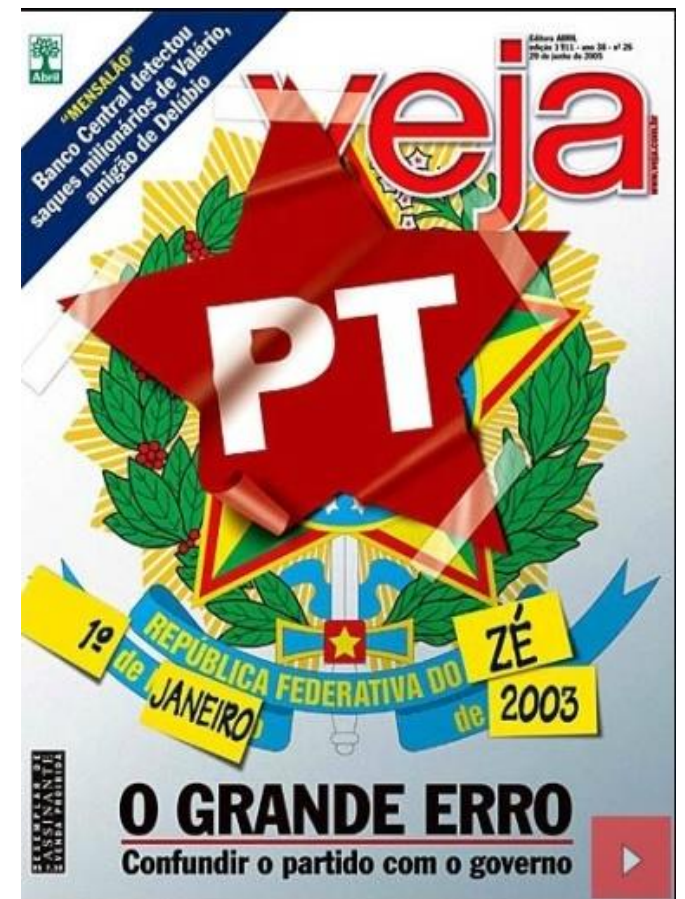

Fonte: Reprodução Acervo Revista Veja 
Figura 5: Edição 1916, 3 de agosto de 2005

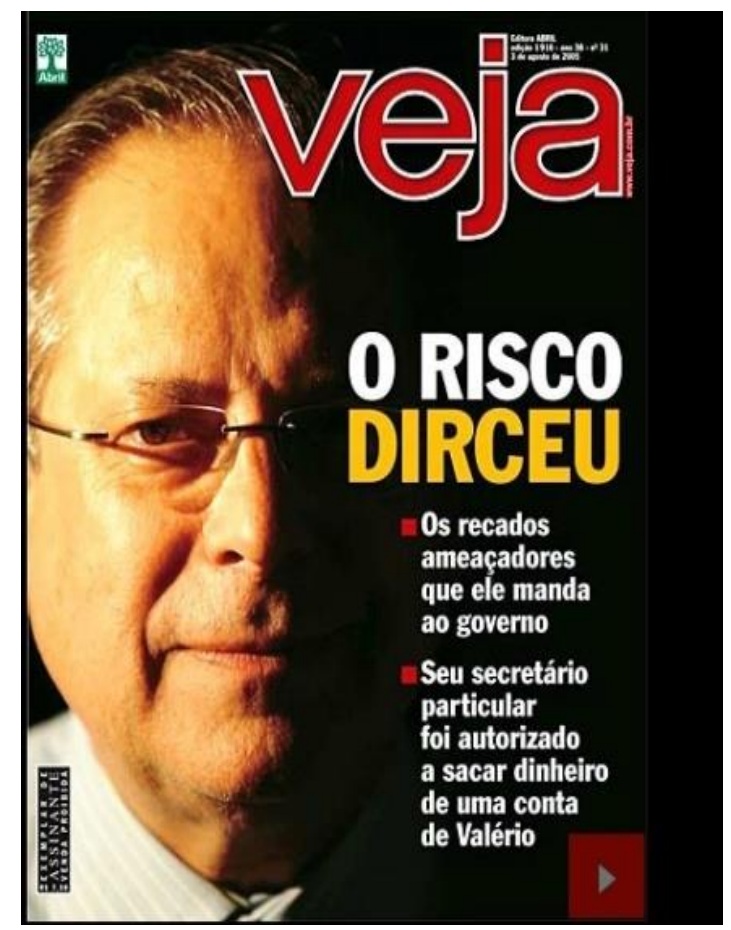

Fonte: Reprodução Acervo Revista Veja

Figura 6: Edição 2232, de 31 de agosto de 2011

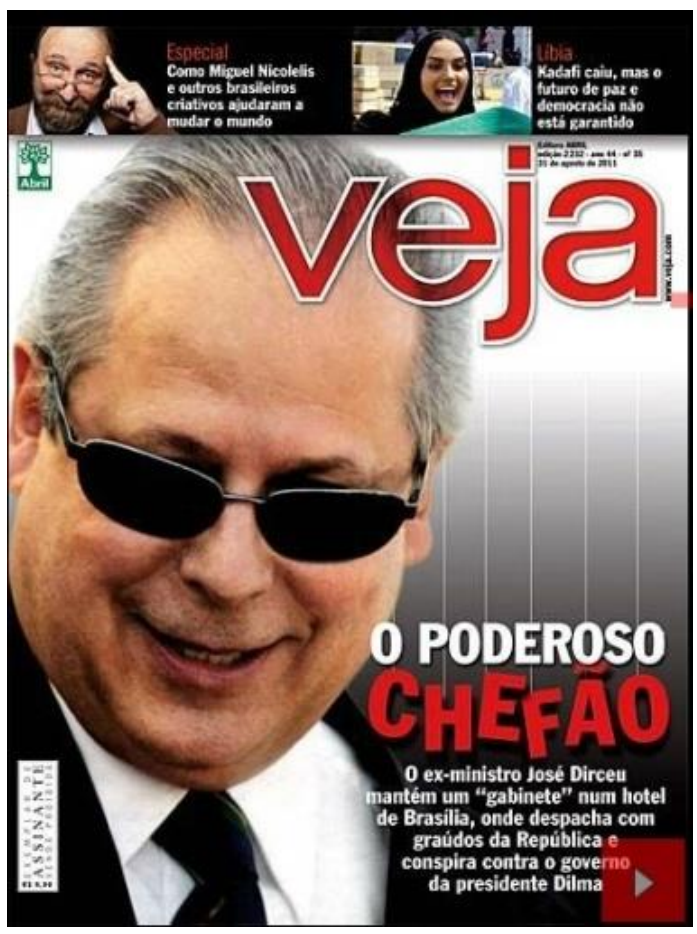

Fonte: Reprodução Acervo Revista Veja 
Figura 7: Edição $2280,1^{\circ}$ de agosto de 2012

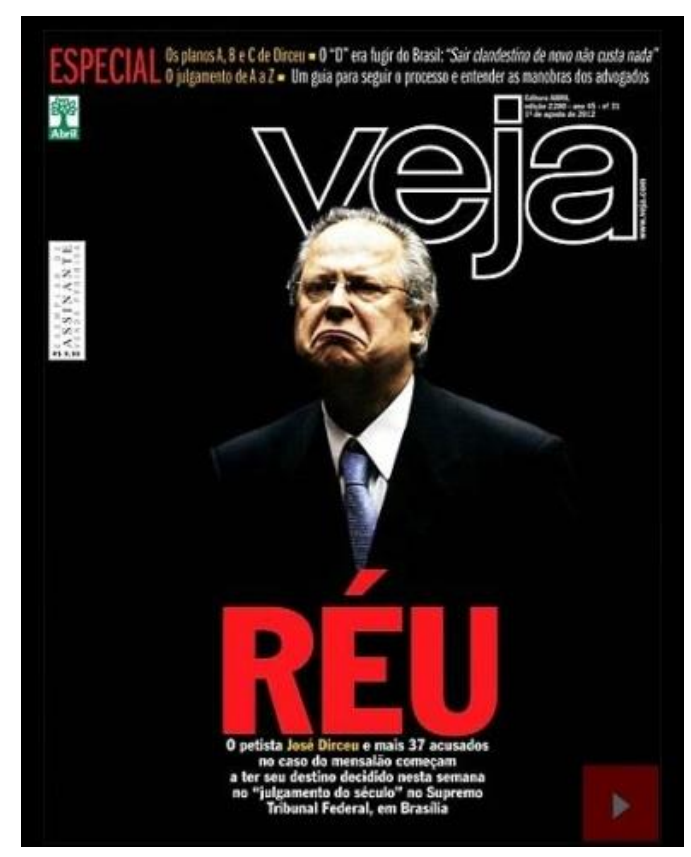

Fonte: Reprodução Acervo Revista Veja

Figura 8: Edição 2325, de 12 de junho de 2013

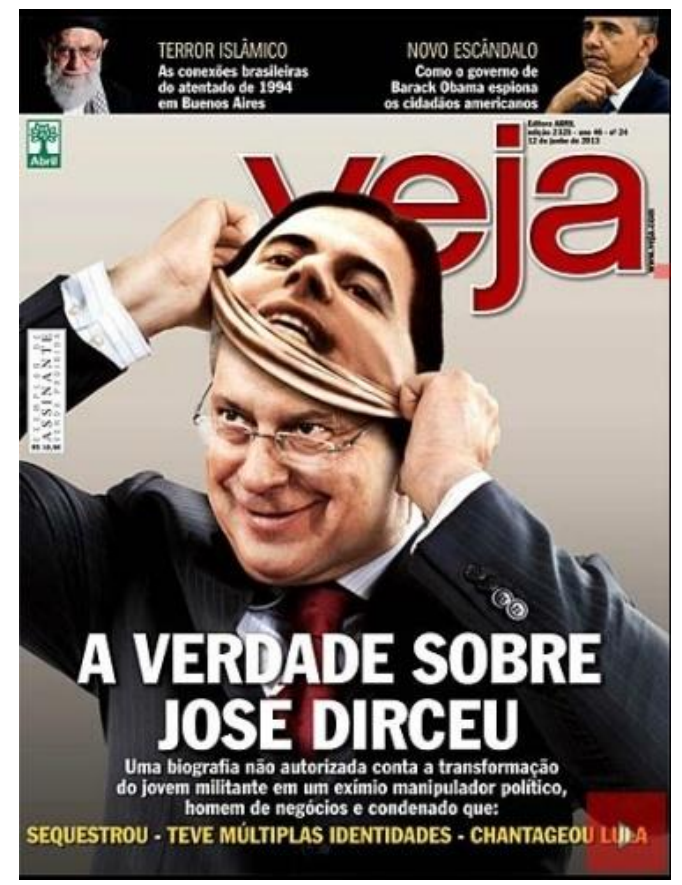

Fonte: Reprodução Acervo Revista Veja 
Figura 9: Edição 2348, 20 de novembro de 2013

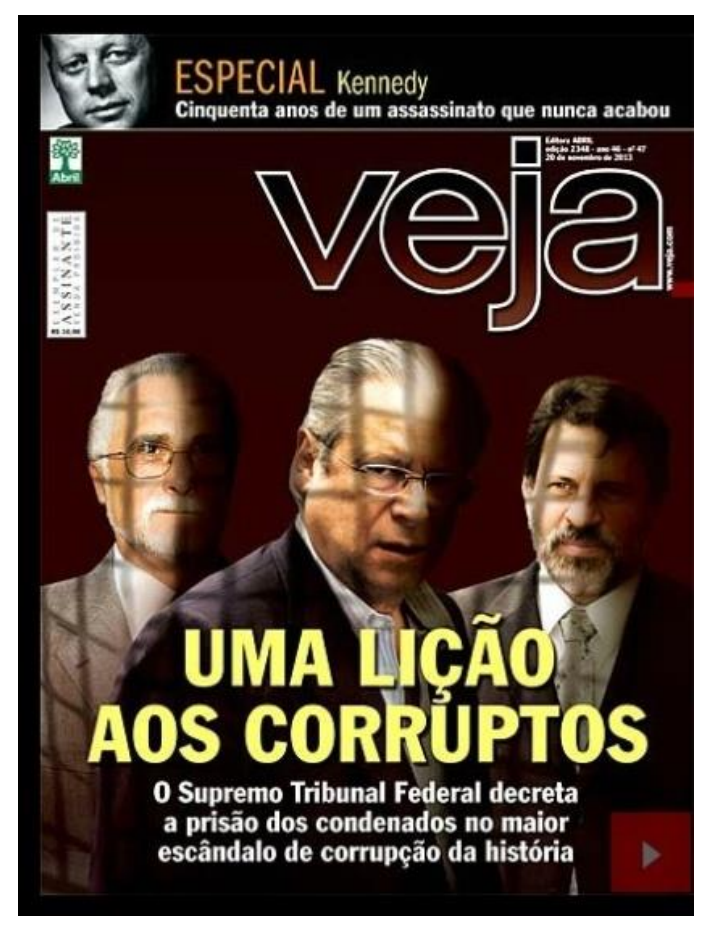

Fonte: Reprodução Acervo Revista Veja

Figura 10: Edição 2349, 27 de novembro de 2013

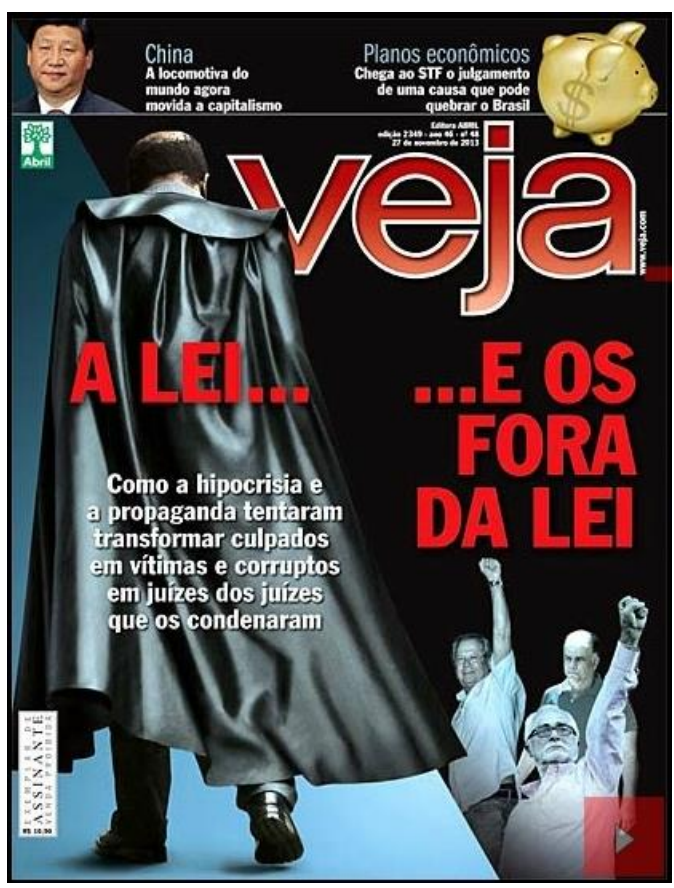

Fonte: Reprodução Acervo Revista Veja 
Figura 11: Edição 2363, de 5 de março de 2014

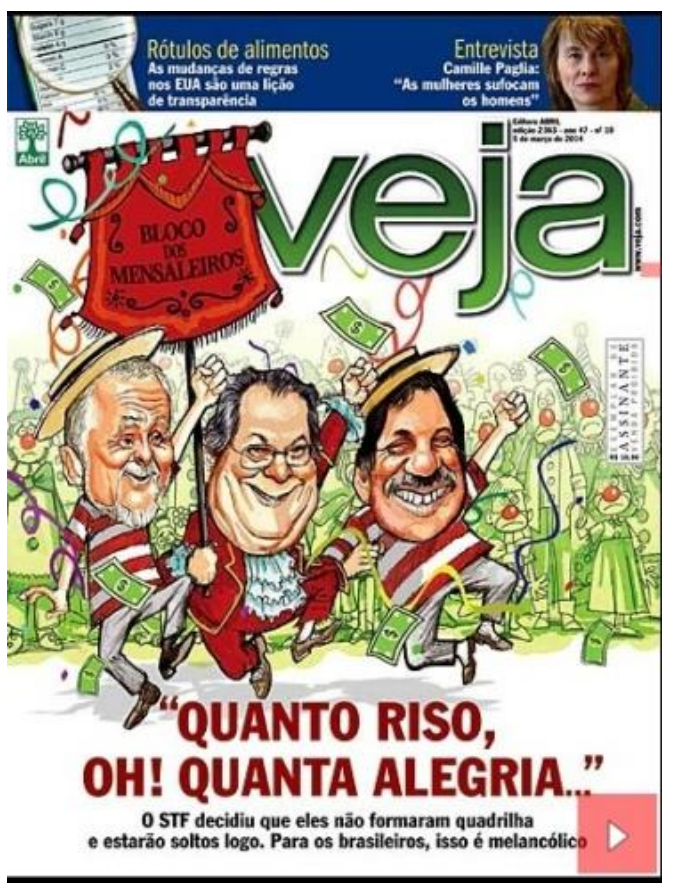

Fonte: Reprodução Acervo Revista Veja

Figura 12: Edição 2365, 19 de março de 2014

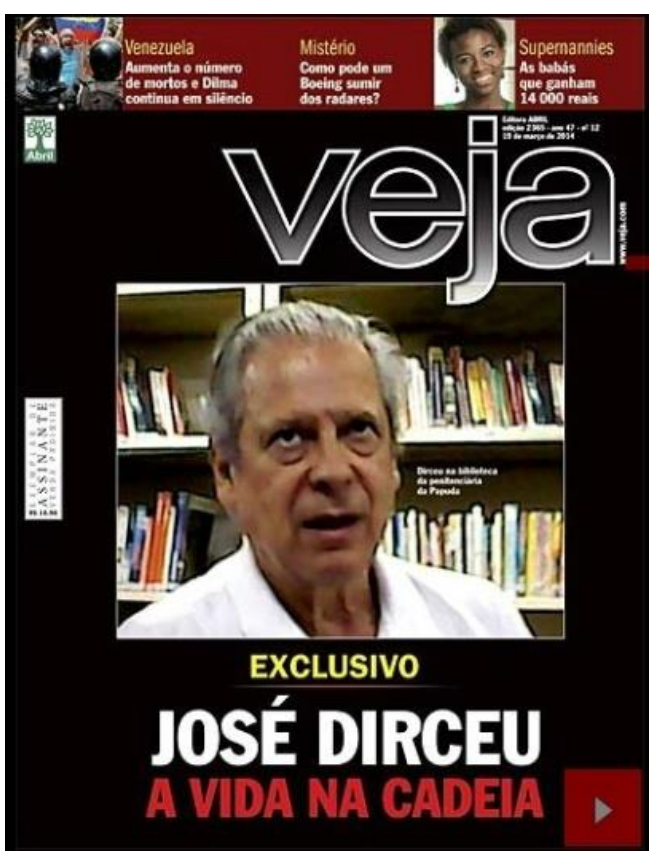

Fonte: Reprodução Acervo Revista Veja 
